\title{
Kritička analiza diskursa o fleksibilizaciji tržišta rada
}

Trbušić, Helena

Doctoral thesis / Disertacija

2021

Degree Grantor / Ustanova koja je dodijelila akademski / stručni stupanj: University of Zagreb, Faculty of Humanities and Social Sciences / Sveučilište u Zagrebu, Filozofski fakultet

https://doi.org/10.17234/diss.2021.7762

Permanent link / Trajna poveznica: https://urn.nsk.hr/urn:nbn:hr:131:083341

Rights / Prava: In copyright/Zaštićeno autorskim pravom.

Download date / Datum preuzimanja: 2023-04-26

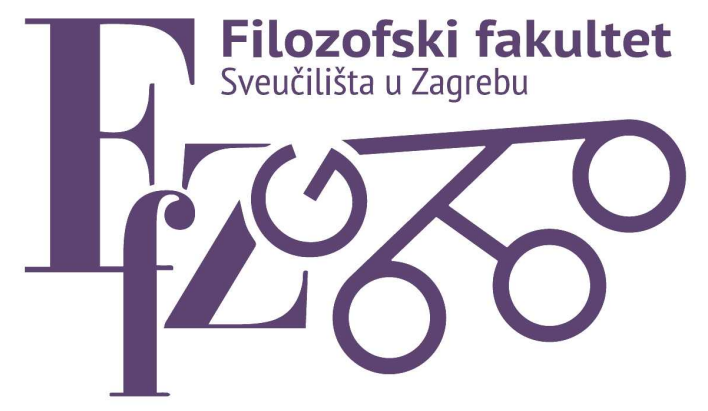

Repository / Repozitorij:

ODRAZ - open repository of the University of Zagreb

Faculty of Humanities and Social Sciences
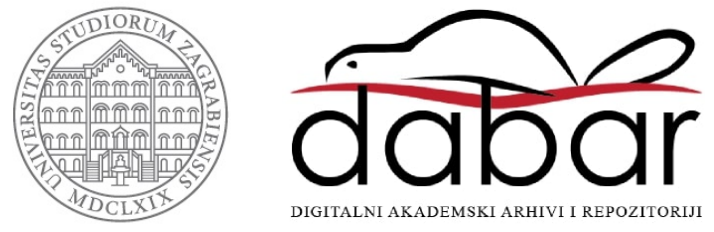


\section{Sveučilište u Zagrebu}

FILOZOFSKI FAKULTET

HELENA TRBUŠIĆ

\section{KRITIČKA ANALIZA DISKURSA O FLEKSIBILIZACIJI TRŽIŠTA RADA}

DOKTORSKI RAD

Zagreb, 2021. 


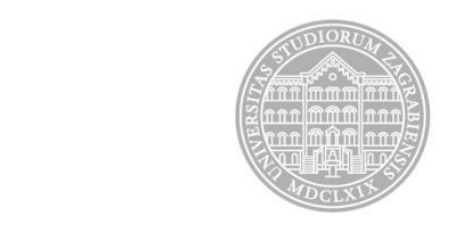

Sveučilište u Zagrebu

FILOZOFSKI FAKULTET

HELENA TRBUŠIĆ

\section{KRITIČKA ANALIZA DISKURSA O FLEKSIBILIZACIJI TRŽIŠTA RADA}

DOKTORSKI RAD

Mentor: prof. dr. sc. Jasminka Lažnjak

Zagreb, 2021. 


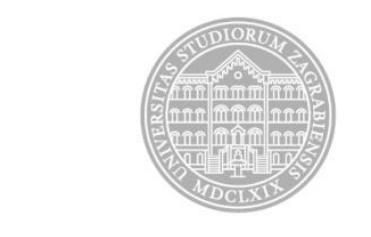

University of Zagreb

FACULTY OF HUMANITIES AND SOCIAL SCIENCES

HELENA TRBUŠIĆ

\section{CRITICAL DISCOURSE ANALYSIS OF LABOR MARKET FLEXIBILIZATION}

DOCTORAL THESIS

Supervisor: Prof. Jasminka Lažnjak, PhD 


\section{Mentorica}

Izv. prof. dr. sc. Jasminka Lažnjak, rođena 28. svibnja 1959. godine u Zagrebu. Godine 1984. diplomirala sociologiju kao jednopredmetni studij na Odsjeku za sociologiju Filozofskog fakulteta Sveučilišta u Zagrebu, a 1990. godine obranila magistarski rad „Profesionalizacija i sekularizacija" (mentor prof. dr. S. Vrcan) na Odsjeku za sociologiju Filozofskog fakulteta Sveučilišta u Zagrebu. Profesorica Lažnjak je 1999. godine obranila doktorski rad „Socijalna konstrukcija tehnologije. Sociološki aspekti odnosa tehnologije i društva" (mentor prof. dr I. Cifrić) na Odsjeku za sociologiju Filozofskog fakulteta Sveučilišta u Zagrebu. Godine 1985. godine počinje predavati na Katedri za društvene znanosti Rudarsko-geološko-naftnog fakulteta Sveučilišta u Zagrebu, i to predmete „Znanost i tehnologija”, „Sociologija” i „Industrijska sociologija”. Od 2000. godine predaje predmete „Znanost, tehnika, društvo”, „Sociologija” i "Sociologija organizacije” na Katedri za zajedničke nastavne predmete Rudarsko-geološkonaftnog fakulteta Sveučilišta u Zagrebu. Godine 2006. izabrana u znanstveno nastavno zvanje docenta u području društvenih znanosti, polje sociologija na Odsjeku za sociologiju Filozofskog fakulteta Sveučilišta u Zagrebu. Suradnica na projektima MZOS-a kontinuirano od 1992. godine kao i na sedam međunarodnih EU projekata (FP6, FP7). Članica Hrvatskog sociološkog društva, Hrvatskog ekološkog društva, Matice hrvatske, European Association for the Study of Science and Technology EASST, International Sociological Association, ISA. Od 2010. do danas Koordinatorica Povjerenstva za upravljanje kvalitetom Filozofskog fakulteta Sveučilišta u Zagrebu. Ak.god. 2012/13 i 2013/14 pročelnica Odsjeka za sociologiju i članica Fakultetskog Vijeća istog fakulteta. Od 1997-2010 kodirektorica međunarodnog seminara „Social Aspects of Sciences” Interuniverzitetskog centra u Dubrovniku, a od 2004-2011 kodirektorica međunarodne konferencije „Innovation and Social Development”, također u Interuniverzitetskom centru u Dubrovniku 1985. primila nagradu Filozofskog fakulteta u Zagrebu za diplomski rad pod naslovom "Analiza stavova diplomiranih studenata sociologije o studiju sociologije”. Od siječnja do kolovoza 1989. godine boravila kao „Visiting Scholar” na Indiana University, Bloomington, SAD. 


\section{SAŽETAK}

Rad se bavi proučavanjem javnog diskursa o fleksibilizaciji tržišta rada u Hrvatskoj u razdoblju izmjena radnog zakonodavstva, odnosno donošenja novog Zakona o radu tijekom 2013. i 2014. godine. Fleksibilizacija tržišta rada, i s njome povezana deregulacija tržišta rada, pitanja su kojima se u suvremenom društvu posvećuje značajna pažnja. Od 1970-ih godina naovamo, masovnu fordističku industrijsku proizvodnju postupno zamjenjuje fleksibilna proizvodnja koju prate fleksibilni oblici rada, te fleksibilizacija i deregulacija tržišta rada. Od prelaska hrvatskog gospodarstva na tržišnu ekonomiju, pojavljuju se naglašeni zahtjevi za fleksibilizacijom tržišta rada ne bi li se otvorila vrata standardizaciji fleksibilnih oblika rada u Hrvatskoj. Spomenute zahtjeve koji su artikulirani u javnom prostoru, prate i neki oponirajući diskursi kojima se prije svega izražava zabrinutost zbog posljedica fleksibilizacije tržišta rada. Doktorat se bavi primjenom kritičke analize diskursa na materijal dnevnih novina kako bi se istražili ideološki aspekti fleksibilizacije i deregulacije tržišta rada u Hrvatskoj. Pod istraživanjem ideoloških aspekata se prvenstveno misli na otkrivanje kombinacije diskursa među kojima bi poseban naglasak bio na neoliberalnom diskursu kao jezičnoj pojavnosti neoliberalne ideologije globalnog kapitalizma. Pri kritičkoj analizi diskursa novinskih članaka primjenjuje se varijanta kritičke analize diskursa koju je osmislio teoretičar i istraživač Norman Fairclough, a podrazumijeva trodimenzionalni model koji omogućuje kontekstualizaciju analize tekstova u okvire diskurzivnih i društvenih praksi. Kroz kritičku analizu diskursa o fleksibilizaciji tržišta rada ustanovljene su teme i argumenti koji upućuju na dominaciju neoliberalnog diskursa u javnom diskursu koji prati deregulaciju tržišta rada, a kojeg zastupaju predstavnici kapitala. Analizom društvenih praksi kroz analizu politika na tržištu rada ustanovljeno je da se snaga diskurzivnih formacija koje se mogu povezati s neoliberalnim diskursom odrazila na provođenje politika na tržištu rada koje se kreću u smjeru fleksibilizacije tržišta rada koja u većoj mjeri pogoduje interesima poslodavaca.

Ključne riječi: kritička analiza diskursa, neoliberalizam, fleksibilizacija tržišta rada, Zakon o radu, socijalna država 


\section{SUMMARY}

The research is focused on the study of public discourse on labor market flexibilization in Croatia during the reform of the Croatian Labor Act which was undertaken by the Croatian government during 2013 and 2014. Labor market flexibilization and labor market deregulation are questions of great interest when it comes to the developments in contemporary Croatian society. Since the 1970s, mass Fordist industrial production had mostly been replaced by flexible production accompanied by flexible forms of labor, and labor market flexibilization and deregulation. During the transition period towards market economy in Croatia, pronounced demands for labor market flexibilization have been vocalized, expressing the need to create market conditions that would allow for the standardization of flexible forms of labor in Croatia. The mentioned demands articulated in the public space have been accompanied by various opposing discourses which express concerns over the consequences of labor market flexibilization. The thesis deals with the application of critical discourse analysis to the material of daily newspapers in order to explore the ideological aspects of flexibilization and deregulation of the labor market in Croatia. The exploration of ideological aspects implies the discovery of a combination of discourses, with special attention given to neoliberal discourse as the linguistic manifestation of neoliberal ideology of global capitalism.

The first part of the dissertation is concerned with describing critical discourse analysis; its origins, historical development, characteristics, founding researchers and their scientific views and propositions regarding the different ways in which research can be conducted relying on the basic premises of CDA. Critical discourse analysis focuses on choosing an actual social issue which is in some way deemed to be problematic in its involvement in the social distribution of power. To be able to activate its potential of social involvement, and to a certain extent its potential of social engagement, critical discourse analysis strives to achieve the ability to facilitate a more just distribution of power in a given society. Because critical discourse analysis not only allows, but encourages the adaptation of a certain research ,angle“ which by the researcher is determined to be best suited for describing the chosen social issue, it is the methodology of choice for this particular research problem dealing with the flexibilization of the Croatian labor market. This research relies on Norman Fairclough's conception of critical discourse analysis which implies a three-dimensional model emphasizing the importance of contextual analysis of text, adding analysis of discursive practices or analysis of interdiscursivity and analysis of social practices, to the analysis of texts. 
The second part of the dissertation involves the description of neoliberalism as a concept, a historical process accompanying globalization, a doctrine, an ideology; the description of neoliberal identity as well as neoliberal discourse. Neoliberalism, whichever way we wish to describe it, is a complex phenomenon, but most theoretical perspectives and schools dealing with trying to describe it, do so from a critical perspective, basically relying on the same theoretical sources and researchers. Therefore, the literature on which this research relies is used more or less indiscriminately of its origin and particular theoretical background or orientation. Useful distinctions used in the dissertation are those between neoliberalism and other liberal schools of thought, neoliberal identity, and the identity of the Keynesian welfare state, as well as the distinction between transparent and euphemized neoliberal discourse. Neoliberalism is also featured as a doctrine with a special perspective on labor market policies, forming unique views regarding organized labor as a kind of monopoly and workers or labor force as human capital and providers on the market.

The third part deals with the analysis of the material which is compartmentalized into three different sections approximately approaching Fairclough's three-dimensional model of critical discourse analysis, or textual analysis, analysis of discursive practices and analysis of social practices. Textual analysis was done as thematic analysis which produced a series of most common themes found in the analyzed material representing the public discourse on labor market flexibilization. The themes discovered ranged from more general issues connected to labor market reform such as foreign investments, reforms in line with the agenda of austerity, tripartite dialogue and collective bargaining, collective action taken by the unions, and various forms of criticism of the undertaken labor market reform from various perspectives. More particular themes included demand for developing and expanding numerical flexibility, in particular wage flexibility, hiring and firing policies, severance pay, and work time flexibility. These demands were proposed by the representatives of employers and foreign investors as well as the government. The opposition to these demands came predominantly from unions who used strike as bargaining leverage.

The second dimension of discursive analysis pertained to the analysis of discursive practices and interdiscursivity of the public discourse. The analysis yielded several types of arguments which according to their characteristics and orientation regarding a specific type of labor market flexibility, can be positioned in the extended domains of either neoliberal discourse or discourse of the welfare state. The arguments which pointed to a certain kind of attitude towards flexibility could not always be neatly demarcated along the lines of neoliberal versus Keynesian, which pointed towards a public discourse shaped as a continuum consisting 
of transparent neoliberal discourse, euphemized neoliberal discourse, discourse of social partnership and discourse of the welfare state. It was established that regarding the analyzed material in terms of theme visibility and the public space allotted to the proponents of arguments at the neoliberal end of the continuum, neoliberal discourse dominated the public discourse on labor market flexibility.

The part pertaining to the analysis of public policy focused on changes implemented in the Labor Act with special attention given to changes which were proposed by various interested actors in public discourse. The analysis also consisted of a review of data on labor market trends provided by the Croatian Employment Service, Eurostat, and the Ministry of Labor and Pension System. The indicators of labor market flexibility provided by these sources point to a substantial influence of the labor market reform on labor market flexibility in Croatia.

Key words: critical discourse analysis, neoliberalism, labor market flexibilization, Labor Act, welfare state 


\section{Sadržaj}

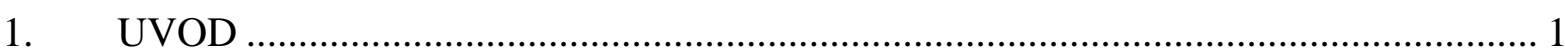

2. ISTRAŽIVAČKI PRISTUP KRITIČKE ANALIZE DISKURSA ……………………....... 5

2.1. Utemeljitelji i povijesni razvoj kritičke analize diskursa .............................................. 5

2.2. Temeljna obilježja kritičke analize diskursa ............................................................ 8

2.3. Utemeljenje društvenog angažmana u kritičkoj analizi diskursa ................................. 12

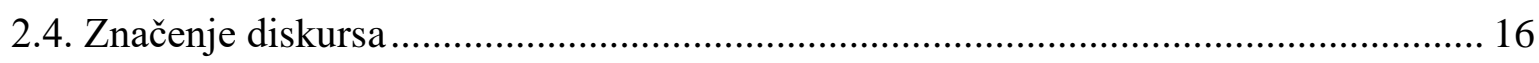

2.5. Ideologija i hegemonija u kritičkoj analizi diskursa .................................................. 21

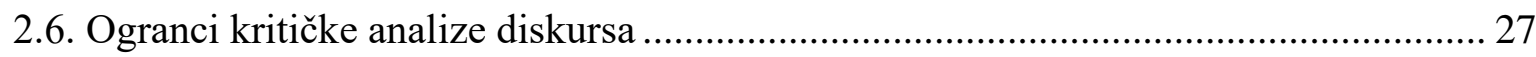

2.6.1. Diskurzivno-historijski pristup kritičkoj analizi diskursa ...................................... 27

2.6.2. Van Dijkova kritička analiza diskursa - sociokognitivni pristup ............................ 30

2.6.3. Faircloughov okvir za kritičku analizu diskursa .................................................... 36

3. NEOLIBERALNI DISKURS I FLEKSIBILIZACIJA TRŽIŠTA RADA .......................... 45

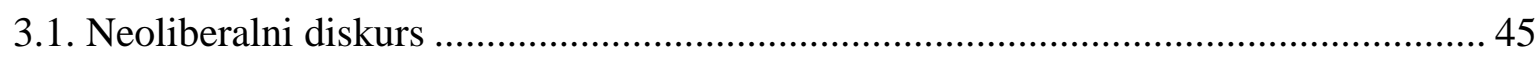

3.1.1. Konceptualizacija neoliberalizma ........................................................................ 45

3.1.2. Povijesni kontekst neoliberalne ideologije ............................................................. 55

3.1.3. Osnovne značajke neoliberalne ideologije ............................................................... 57

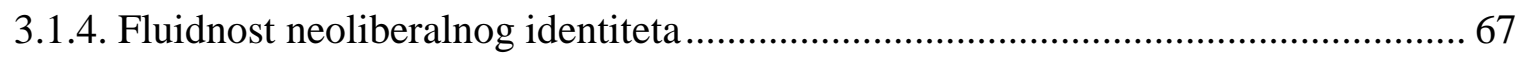

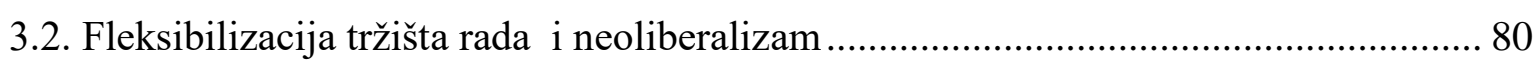

3.2.1. Neoliberalni diskurs o fleksibilizaciji tržišta rada .................................................... 86

4. FLEKSIBILIZACIJA TRŽIŠTA RADA U HRVATSKOJ _............................................. 103

5. CILJ ISTRAŽIVANJA I ISTRAŽIVAČKA PITANJA ……………………………..... 111

6. PRIKUPLJANJE I OBRADA MATERIJALA ZA ANALIZU …………………………... 112

7. OBILJEŽJA JAVNOG DISKURSA O FLEKSIBILIZACIJI TRŽIŠTA RADA U

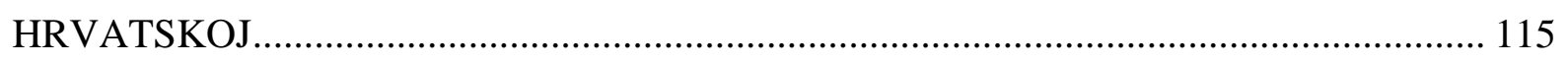

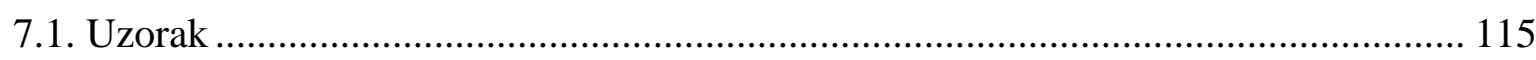

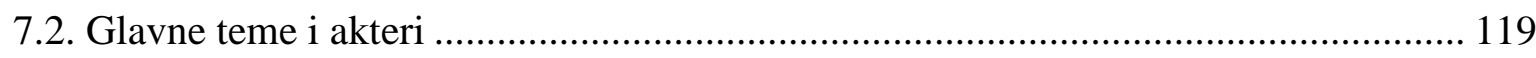

7.2.1. Teme novinskih članaka iz razdoblja usklađivanja Zakona o radu s direktivama Europske Unije (1. 1. 2013. - 15. 6. 2013.) ................................................................ 119 
7.2.2. Teme iz razdoblja javne rasprave, pregovora i donošenja novog Zakona o radu (16.

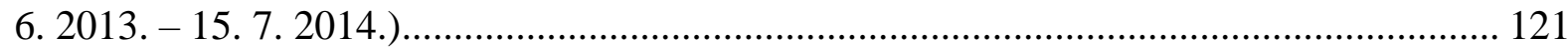

7.3. Analiza novinskih tekstova odabranih u uzorak .................................................... 126

7.3.1. Prijedlozi promjena Zakona o radu u području numeričke fleksibilnosti ............. 127

7.3.2. Prijedlozi promjena Zakona o radu u području fleksibilnosti plaća...................... 129

7.3.3. Prijedlozi promjena Zakona o radu u području fleksibilnosti radnog vremena .... 129

7.3.4. Gospodarska kriza i mjere štednje ................................................................... 130

7.3.5. Gospodarska kriza i privlačenje stranih ulaganja................................................ 132

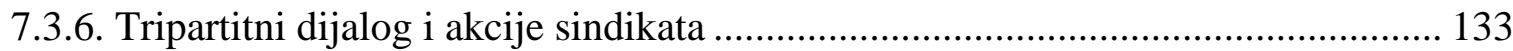

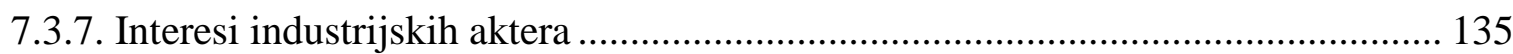

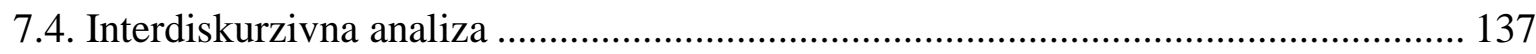

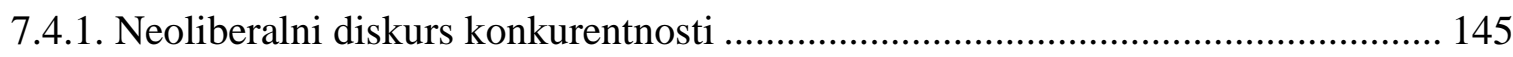

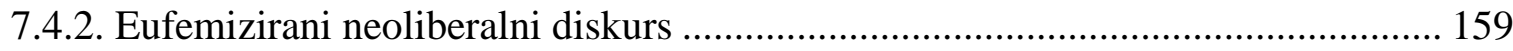

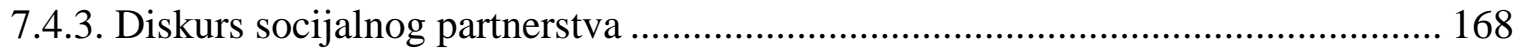

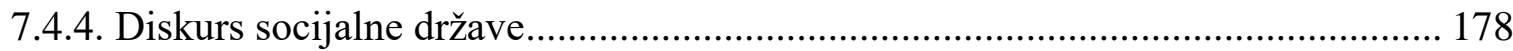

7.5. Analiza zastupljenosti argumentacija po akterima..................................................... 181

7.5.1. Javni diskurs sindikata o fleksibilizaciji tržišta rada .......................................... 181

7.5.2. Javni diskurs poslodavaca o fleksibilizaciji tržišta rada...................................... 181

7.5.3. Javni diskurs predstavnika Vlade o fleksibilizaciji tržišta rada ............................ 184

8. ANALIZA POLITIKA NA TRŽIŠTU RADA ............................................................. 186

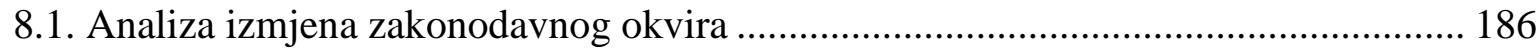

8.1.1. Izmjene koje se odnose na mogućnosti numeričke fleksibilnosti ....................... 187

8.1.2. Izmjene koje se odnose na proširenje mogućnosti fleksibilnosti radnog vremena 203

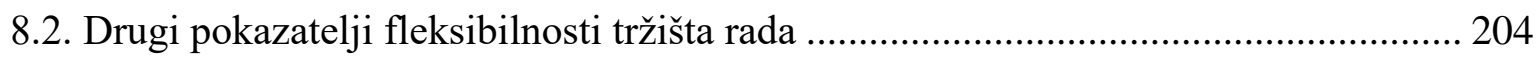

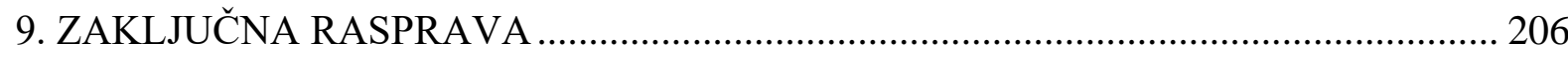

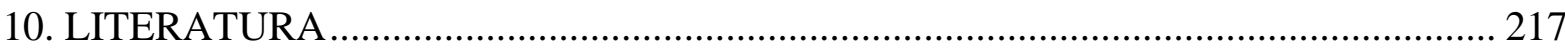

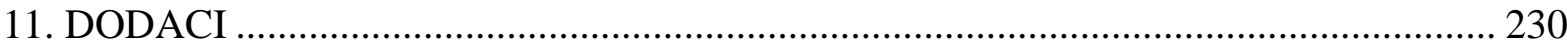




\section{UVOD}

Pitanje fleksibilizacije tržišta rada postalo je jedno od ključnih pitanja ekonomskih i industrijskih politika tijekom posljednja dva desetljeća 20. stoljeća, a nastalo je u jeku slabljenja kapitalizma socijalne države (eng. welfare capitalism). Fleksibilizacija tržišta rada prati povijesnu transformaciju režima kapitalističke akumulacije; iz fordističkog režima kapitalističke akumulacije u postfordistički (Jessop 2003, Birch 2017). Fordizam je sustav masovne industrijske proizvodnje koji je stvarao velik broj radnih mjesta, gotovo punu zaposlenost, snažno organizirano radništvo te socijalnu državu koja je pružala svima dostupne javne usluge obrazovanja, zdravstva i drugih socijalnih jamstava, i koji je koordinirao preraspodjelu dobara u društvu s ciljem osiguravanja što većeg blagostanja za što veći broj ljudi. Akumulacijski režim postfordizma koji je uslijedio, bio je između ostalog i rezultat napretka i modernizacije tehnologije, a utemeljen je na fleksibilizaciji industrijske proizvodnje, koja se odnosila na prilagodbu tvrtki globaliziranom tržištu, što se sve više počelo odnositi i na promjenu percepcije o zaštiti i pravima radnika, s obzirom na to da su upravo te zaštite identificirane kao najveća barijera fleksibilizaciji samih tvrtki. U kontekstu fleksibilizacije poslovanja kompanija i njihovog prilagođavanja konkurenciji na globalnom tržištu, regulacija tržišta rada i radnička prava koja su različita u različitim državama shvaćena su kao prepreka konkurentnosti poslodavaca te su nastajali sve glasniji zahtjevi da se fleksibilizacija treba provoditi i kada se radi o radničkim pravima i industrijskim odnosima. S tom su svrhom oblikovane politike deregulacije tržišta rada kako bi se ono učinilo fleksibilnim kao što je to slučaj s cjelokupnim proizvodnim i radnim procesom. Kao posebno neprilagodljivima kada je riječ o radnim odnosima i tržištu rada, označene su države u Europi. Naime, Europa je tijekom krize države blagostanja imala visoku razinu nezaposlenosti, pa je dijagnoza tog stanja bila takozvana euroskleroza kao posljedica reguliranih, odnosno „rigidnih“ tržišta rada, dok je pretpostavljeni lijek bio smanjivati regulaciju, ukinuti „rigidnosti“ jer one sprječavaju zapošljavanje i napredak gospodarstava, i s druge strane na neki način privoljeti, ili čak natjerati radnike da u interesu kapitala i vlastitog snalaženja na tržištu budu „mobilni“, „fleksibilni““, „prilagodljivi““, a time i lakše ,zapošljivi“ na tržištu. Zemlje Europe su, svaka na svoj način pristupale procesu fleksibilizacije tržišta rada ne bi li se na neki način prilagodile novim okolnostima koje su nastale procesom globalizacije i međunarodnim tržišnim pritiscima za smanjivanjem cijene rada. Zemlje istočne Europe, odnosno višegradske skupine, izuzev Češke, ranih su 2000-ih godina, pod pritiskom stranih ulagača i međunarodnih organizacija pristupile deregulaciji radnog zakonodavstva. Radno zakonodavstvo je u zemljama istočne Europe bilo 
pod pritiskom zahtjeva za deregulacijom. Značajni pritisak dolazio je zbog okolnosti pristupanja tih zemalja Europskoj uniji i usklađivanja zakonodavstva $\mathrm{s}$ acquis communautaireom:

„...tijekom procesa pristupanja, zemlje su trebale harmonizirati svoje radno zakonodavstvo s Acquis Communautaireom. Iako je Acquis ojačao prava radnika u nekim aspektima, također je stvorio žustre rasprave o fleksibilnosti tržišta rada, osobito vezano uz odredbe koje su se ticale radnog vremena i otpuštanja. Promjene radnih zakona povezane s ulaskom u EU pružile su prilike poslodavcima, a osobito izravnim inozemnim ulagačima, koji su lobirali za fleksibilnije radno zakonodavstvo već godinama. U Slovačkoj, liberalni zakon o radu odražava preferencije stranih ulagača (Munkova 2004: 4, Bohle i Greskovits 2006). U Poljskoj i Mađarskoj su i vlade tijesno surađivale s najvećim poslodavcima kako bi reformirali radno zakonodavstvo.“

Bohle (2009: 182)

U Hrvatskoj se proces fleksibilizacije odvijao, ili se još uvijek odvija, drugačijim putevima, također zbog njezinog povijesnog nasljeđa, odnosno tranzicije iz socijalizma $u$ kapitalizam, koja se zbog Domovinskog rata ponešto razlikovala od tranzicija drugih bivših socijalističkih zemalja u Europi. Međutim, Hrvatska je ipak na vrlo sličan način, tek u vrijeme pristupanja Europskoj uniji, odnosno 2013. i 2014. godine, slično kao i druge zemlje istočne Europe, odnosno prilikom usklađivanja vlastitog zakonodavstva s onim Europske unije, doživjela možda i najsnažniji pritisak ne bi li u što većoj mjeri fleksibilizirala radno zakonodavstvo, a razmjere te fleksibilizacije osvještavamo sve do danas.

U ovom je radu pristup proučavanju problematici fleksibilizacije tržišta rada utemeljen na analizi javnog diskursa o fleksibilizaciji kako se on materijalizira i prenosi kroz novinske tekstove prisutne $\mathrm{u}$ javnoj sferi upravo tijekom izmjena hrvatskog Zakona i radu, u kojoj pretežno sudjeluju industrijski akteri, odnosno sindikati, poslodavci i vlada, odnosno predstavnici države. Za analizu je odabrana vrsta diskurzivne analize koju nazivamo kritičkom analizom diskursa. Ona je pogodna za analizu datog istraživačkog problema jer u sebi sadrži metodološke propozicije koje omogućuju kritičku perspektivu problema fleksibilnosti tržišta rada $\mathrm{i}$ istraživanje konstelacije izvora moći koji sudjeluju u oblikovanju javnog diskursa o fleksibilizaciji. Naime, kritička analiza diskursa daje prikaz diskurzivnih praksi koje su neraskidivo povezane $\mathrm{s}$ političkim, ekonomskim i drugim društvenim praksama $\mathrm{o}$ 
fleksibilizaciji kao njihov jezični atribut. Prvi je dio rada zato usredotočen na konceptualizaciju samog pristupa istraživačkom problemu, a to je kritička analiza diskursa s posebnim naglaskom na sistematizaciju istraživanja u okviru analitičkog pristupa Normana Fairclougha, kojim se nastoji osigurati kontekstualni pristup analizi teksta postavljajući je u odnose s diskurzivnim praksama i društvenim praksama. Ukratko je opisana povijest nastanka kritičke analize diskursa kao heterogenog istraživačkog programa koji je osobito pogodan za analizu prijepornih društvenih problema kojima dominiraju specifični interesi. Kritička analiza diskursa unatoč svojoj heterogenosti ima određene zajedničke karakteristike koje je moguće sažeto opisati i primijeniti kao model konstrukcije kvalitativnog istraživanja s odgovarajućim stupnjem slobode prilagodbe istraživačke metode samim posebnostima istraživačkog problema. Fleksibilizacija tržišta rada prijeporno je pitanje jer se na njemu sukobljavaju interesi rada, odnosno sindikata, i kapitala, odnosno poslodavaca, što same rasprave i argumentacije o navedenom procesu najčešće opterećuje naglašenim ideološkim predznacima. Bilo da se fleksibilizacija zagovara ili osporava, mali se dio rasprave zapravo vodi argumentima utemeljenima na dokazanim utjecajima same (de)regulacije, odnosno fleksibilizacije, na kretanja na tržištu rada.

Drugi se dio sastoji od konceptualizacije neoliberalizma i neoliberalnog diskursa te njegova odnosa prema diskursu socijalne države kao suprotnom polu osi mogućeg gravitiranja diskurzivnih formacija o fleksibilizaciji tržišta rada. Opisivanje neoliberalnog diskursa najvećim dijelom „oscilira“ između kritički orijentiranih pristupa poznatih teoretičara neoliberalizma kao što su Bastiaan van Apeldoorn, Damien Cahill, Mark Blyth, Sean Phelan, Leah Vosko, Stephen McBride, Jamie Peck, Wendy Larner, Ben Jackson, Michel Foucault, Norman Fairclough i drugi, te pogleda na fleksibilizaciju tržišta rada iz perspektive znanstvenika koji pripadaju socijalnodemokratskoj, kejnzijanskoj struji, koji su, moglo bi se reći nešto umjerenijeg stava prema procesu fleksibilizacije tržišta rada ukoliko se ona uistinu vodi interesima radnika i u duhu istinskog kompromisa. U kontekstu određenog dijela akademskog diskursa o neoliberalnim politikama na tržištu rada, nastoji se u što je većoj mogućoj mjeri izbjegavati ideološki predznak kako u općoj perspektivi, tako i pri interpretaciji znanstvenih istraživanja i što je moguće više pozivanjem na empirijski utemeljene argumente. Spomenuta, blago kritička perspektiva, fleksibilizaciji dopušta i određene prednosti u kontekstu tehnološke modernizacije industrijske proizvodnje i radnih odnosa, koji se prilagođavaju novonastalim uvjetima na tržištu rada i prevlasti sektora usluga u udjelu sveukupnog zapošljavanja. U potonju kategoriju znanstvenika možemo svrstati, na primjer, Petera Auera, 
Dragana Bagića, Simona Deakina, Gostu Esping-Andersena, Marija Reginija, Franka Wilkinsona, zajedno s manje kritičkim pristupima neoliberalizmu i deregulaciji koje imaju Tito Boeri i Jan van Ours te Rachel Turner.

Analizi samih novinskih tekstova pristupa se kroz diskurzivnu analizu Faircloughova kritičkog pristupa s naglaskom na analizu neoliberalne koncepcije tržišta rada u javnom diskursu, kojoj oponiraju perspektive srodne shvaćanju tržišta rada kao skupa institucija „uglavljenog“ u društvene odnose, koje stoga mimo onih ekonomskih, imaju i svoje socijalne karakteristike i funkcije. Kroz analizu tema i argumentacija u kojima se u javnom diskursu pojedini akteri zalažu za provođenje određenih aspekata fleksibilizacije ili im se pak protive, ustanovljava se interdiskurzivni poredak, ili pak kontinuum međusobno različitih, a opet srodnih i povezanih diskursa koji se pojavljuju u javnom diskursu o fleksibilizaciji tržišta rada. Iz ove analize diskurzivnih praksi proizlaze zaključci o argumentima koji se upotrebljavaju kao oslonac u raspravi o fleksibilizaciji tržišta rada, kao i o tome koje argumentacije koriste koji industrijski akteri, na koji je način tržište rada percipirano u javnom diskursu, s kojom konstelacijom tema je povezana tema fleksibilizacija tržišta rada i koja su traženja industrijskih aktera kada je riječ o oblikovanju javnih politika na tržištu rada.

Posljednji se dio rada odnosi na uklopljenost diskurzivnih praksi u društvene prakse, pa su u njemu analizirane javne politike na tržištu rada povezane s javnim diskursom o tržištu rada, odnosno izmjene Zakona o radu i načini na koje su se te izmjene odrazile na fleksibilnost hrvatskog tržišta rada. Analiza društvenih praksi temeljila se na proučavanju dostupnih podataka, odnosno na izvješćima i analizama Hrvatskog zavoda za zapošljavanje, Ministarstva rada i mirovinskog sustava, Eurostata, kao i odgovarajućeg zakonskog okvira. 


\section{ISTRAŽIVAČKI PRISTUP KRITIČKE ANALIZE DISKURSA}

\subsection{Utemeljitelji i povijesni razvoj kritičke analize diskursa}

Kritičkoj je analizi diskursa prethodio razvoj lingvističke discipline koja se naziva kritička lingvistika. Kritička lingvistika nastala je početkom 1970-ih godina na Sveučilištu East Anglia, a njezini su utemeljitelji bili Roger Fowler, Tony Trew i Gunther Kress, koji su svoja istraživačka nastojanja angažirano usmjerili na društvene probleme nejednakosti, pa su u skladu s time u naziv novonastale discipline u okviru znanosti jezikoslovlja uklopili pridjev „kritička“ po uzoru na kritičku sociologiju (Kress 1990, Weiss i Wodak 2003). Tada je osnovana jedna kritička grana u lingvistici koja se razlikovala od dotadašnjih analiza iz područja tekstualne lingvistike, pragmatike i sociolingvistike. Iako su se u spomenutim područjima, kao i u kritičkoj lingvistici, analizirala pitanja uporabe jezika u društvenom kontekstu, kod njih je, za razliku od kritičke lingvistike, jezik shvaćan kao izolirani sustav neovisan o izravnom utjecaju društvenog konteksta u kojemu se upotrebljavao. Tako, na primjer, sociolingvistika ili pragmatika, polaze od jezika kao neovisnog sustava čije je djelovanje određeno pravilima izvan sfere utjecaja društvenoga, dok kritička lingvistika (a kasnije kritička analiza diskursa) ,polazi od društvenog i kreće k lingvističkom, odnosno, ona vidi i smješta lingvističko u okvire društvenoga“" (Kress 1990: 87). Kritička je lingvistika nastojala u disciplinu lingvistike uvesti alternativu sociolingvističkoj i Chomskyjevoj paradigmi koje su postale dominantne, i to utemeljenjem pristupa koji se zasniva na „sistemskoj gramatici“ Michaela Hallidaya (Fairclough 2006/1992). Distanciranje kritičke lingvistike od središnje struje lingvističke znanosti u osnovi se zasnivalo na odbijanju dvaju za tadašnju lingvistiku temeljnih pretpostavki. Prva pretpostavka tretira jezik kao sustav odvojen od jezika u praksi i smatra da se jezik može proučavati kao izolirani sustav, a da se ne uzima u obzir njegova društvena ukorijenjenost. O prvoj se pretpostavci Halliday izjasnio rekavši da je jezik nastao kao funkcija društvene strukture (Fairclough 2006/1992). Jezik se ne može odvojiti od društvenog konteksta jer jezik kao sustav nije odvojen od jezične uporabe, a dostupan je govornicima u obliku koji je ovisan o njihovom položaju u društvenom sustavu (Fairclough 2006/1992). Druga pretpostavka se odnosi na odvajanje ,značenja“ od „stila“, odnosno na odvajanje „sadržaja“ od „,forme“. Kritička lingvistika prema spomenutim pretpostavkama promatra gramatiku nekog jezika kao sustav čijoj konstrukciji kroz korištenje, kroz praksu, doprinose izbori govornika, koji naime mogu birati različite rečenične konstrukcije kako bi izrekli slične stvari, a ti njihovi izbori ovise o društvenim okolnostima u kojima se oni 
nalaze. Drugim riječima, izbori govornika čak i kada je riječ o formalnim karakteristikama jezika, kao što je gramatika, uvijek imaju neko značenje (Fairclough 2006/1992). Iz navedenih se pretpostavki razvijalo nastojanje kritičke lingvistike da eksplicitnije i angažiranije spoji lingvističko s društvenim. Gunther Kress (1990) spominje da je kritička lingvistika formirana u želji da se dosegnu dva osnovna cilja tekstualne analize: da se iz postojećih grana lingvistike izdvoje određeni lingvistički konceptualni alati za analizu te da se pomoću njihove primjene otkriju manifesni i latentni odnosi moći u društvu koji se reflektiraju u samim lingvističkim strukturama analiziranih tekstova. Ta dva cilja podrazumijevaju povezivanje same lingvistike s odnosima moći i pitanjima društvene jednakosti. Preko razvoja kritičke lingvistike, pa do osnivanja kritičke analize diskursa, korištenje je različitih lingvističkih alata bilo eklektično te je podrazumijevalo spajanje spomenutih osnovnih ciljeva kritičke lingvistike s analitičkim alatima razvijenima u okviru funkcionalne gramatike Michaela Hallidaya. Spomenuti se eklekticizam odnosio na uporabu pojedinih „deskriptivno-dijagnostičkih alata“ kao raznovrsnog skupa doprinosa znanstvenika iz cjelokupne lingvističke domene i to tijekom duljeg vremenskog perioda u kojem su ti alati dorađivani. Kress (1990) kaže da se eklekticizam korištenja lingvističkih alata nastavio i u istraživanjima kritičke analize diskursa, ali se ne smatra problematičnim, tj. ne inzistira se na sustavnijem pristupu u uporabi jedinstvene $\mathrm{i}$ jasno ocrtane metodologije.

Iako se kritička lingvistika uzima kao polazište pri opisu povijesnog razvitka kritičke analize diskursa, postoji određeno razilaženje među znanstvenicima o odnosu te dvije discipline. Primjerice, Weiss i Wodak (2003) kažu da je kritička lingvistika, koja se razvijala tijekom 1970-ih i 1980-ih, naknadno preimenovana u kritičku analizu diskursa te da se trenutno oba termina upotrebljavaju u istom značenju, dok Gunther Kress (1990) govori da je kritička lingvistika prethodila kritičkoj analizi diskursa, da bi na koncu prerasla u komponentu kritičke analize diskursa, a kritička analiza diskursa ima šire područje istraživanja i raznovrsniju metodologiju te je multidisciplinarna jer uključuje komponente sociologije, kognitivne znanosti i istraživanja medija. Pod osobitostima kritičke analize diskursa navodi karakteristike ,isticanja moći, sposobnosti individualnog djelovanja i kritike društvenih pitanja“ (Kress 1990: 88). Fairclough (2006/1992) pak ističe kako nije sporno da se začeci kritičke analize diskursa nalaze u kritičkoj lingvistici, ali da se prilikom istraživanja kritička lingvistika pokazala previše ograničavajućom za ambiciozni projekt koji su pred sebe postavili istraživači unutar navedene discipline. Naime, za Fairclougha (2006/1992) kritička lingvistika ima dva osnovna nedostatka. Ona gotovo da je isključivo usmjerena na analizu tekstova, ne uzimajući u obzir načine na koji 
su ti tekstovi nastali i kako se interpretiraju s obzirom na to kome su namijenjeni. Dakle, iako ona jest orijentirana na proučavanje jezika u društvenom kontekstu, ona taj sami kontekst ne proučava dovoljno temeljito. Drugi se nedostatak odnosi na to što kritička lingvistika istražuje utjecaj diskursa na reprodukciju postojećih društvenih struktura, ali ne gleda na diskurs kao na mjesto gdje se odvijaju društveni sukobi te na koji se način promjene u društvu reflektiraju u promjenama u diskursu (Fairclough 2006/1992). Fairclough (2006/1992) želi naglasiti kako korisnici koji interpretiraju tekst nisu pasivni primatelji poruka koje promoviraju određenu ideologiju, već sudionici u pregovaranju o značenju tih istih poruka te da je diskurs arena na kojoj se suočavaju različite interpretacije pojedinih društvenih praksi.

Skupina istraživača povezana s kritičkom analizom diskursa počela se okupljati početkom 1990-ih godina. U to su vrijeme Teun van Dijk, Norman Fairclough i Ruth Wodak gotovo istodobno počeli objavljivati svoja kritička istraživanja integrirana s lingvističkim metodama. Uslijedilo je pokretanje časopisa Teuna van Dijka pod nazivom Diskurs $i$ društvo (Discourse and Society) 1990. godine. U siječnju 1991. Teun van Dijk organizirao je sastanak s kolegama Ruth Wodak, Normanom Faircloughom, Guntherom Kressom i Theom van Leeuwenom u Amsterdamu, koji se danas smatra „formalnim institucionaliziranim početkom kritičke analize diskursa“ (Kendall 2007). Na simpoziju je utvrđeno stanje stvari što se tiče korištenja raznih metoda analize i teorija koje su podupirale osnovne ciljeve kritičke analize diskursa te su se istraživači suočili s raznolikošću pristupa kritičkoj analizi diskursa svojih kolega. Tijekom sastanka su ustanovljene programatske sličnosti discipline koje su predstavljale temeljni teorijski konstrukt na koji su mogli biti nadograđivani raznoliki pristupi kritičkoj analizi diskursa ovisno o procjenama istraživača i potrebama koje iziskuje istraživani društveni problem. Wodak i Meyer (2009) ističu da su se od utemeljenja programa kritičke analize diskursa mnogi istraživači distancirali od tog pristupa slijedeći neke druge teorijske okvire, poput na primjer Gunthera Kressa, ali je u međuvremenu integriranjem drugih socioloških, psihologijskih i lingvističkih teorija stvoreno i nekoliko novih ogranaka koji se mogu smatrati komponentama kritičke analize diskursa, kao što je na primjer teorija socijalnih aktera Thea van Leeuwena, koja se oslanja na Bernsteinovu teoriju o rekontekstualizaciji iz područja sociologije obrazovanja (van Leeuwen 2008).

Osim što je simpozij u Amsterdamu naznačio obrise nastale kritičke analize diskursa i njezinog budućeg razvoja, sudionici simpozija su također nastojali uspostaviti program razmjene istraživača u programu ERASMUS te zajedničke projekte i suradnju između znanstvenika iz mnogih zemalja, a izdan je i poseban broj časopisa Diskurs i društvo 1993. 
godine koji se bavio pojedinim pristupima kritičkoj analizi diskursa. Od 1990-ih godina do danas osnovani su novi znanstveni časopisi poput Kritičkih istraživanja diskursa (Critical Discourse Studies), Časopisa za jezik i politiku (Journal of Language and Politics), Diskurs $i$ komunikacija (Discourse and Communication) te Vizualne semiotike (Visual Semiotics). Uz održavanje redovitih konferencija, priručnika, i e-časopisa, Wodak i Meyer (2009) ističu kako je kritička analiza diskursa postala „etablirana disciplina, institucionalizirana diljem svijeta na mnogim odsjecima i kurikulima“.

\subsection{Temeljna obilježja kritičke analize diskursa}

Kao što vidimo iz Kressova (1990) opisa kritičke lingvistike, kritička analiza diskursa preuzela je mnoga njezina obilježja i nastavila se razvijati u jednoj eklektičnoj maniri, protejski se prilagođavajući predmetima istraživanja i preferencijama samih istraživača. Zbog toga je ponekad teško iznositi neki sustavni prikaz osnovnih karakteristika teorije i metode kritičke analize diskursa jer poznati istraživači tog područja, poput Wodak, Fairclougha, Van Dijka i van Leeuwena, razvijaju specifične pristupe istraživačkim problemima prema vlastitim znanstvenim interesima i percepciji same discipline; s mrežom pojmova, ključnih koncepata i konceptualnih alata koji se gotovo jednako često razilaze u značenjima koliko se i sastaju. Unatoč tome što Kress (1990) tvrdi da u pozadini empirijskih istraživanja kritičke analize diskursa postoji određena teorijska stabilnost, Weiss i Wodak (2003) opisuju kako je zaista teško pratiti, opisati i sistematizirati njezin teorijski razvitak. Prilikom teorijske formacije kritičke analize diskursa kontinuirano su bili, i još jesu, prisutni mnogi izvori, što je proizvelo probleme u konzistentnoj sistematizaciji njezine teorijske pozicije. Unutar kritičke analize diskursa nalazimo veliki broj epistemoloških i društvenih teorija, zatim teorija srednjeg dometa, mikrosocioloških teorija, socijalnopsiholoških teorija te lingvističkih teorija i teorija diskursa (Weiss i Wodak 2003). Često se kao važni teorijski oslonci uzimaju radovi Michela Foucaulta i Jurgena Habermasa, pa je tako Foucault katkad zastupljen na epistemološkoj razini, a katkad na razini teorije diskursa, dok se Habermasov doprinos u okviru kritičke analize diskursa ponekad odnosi na njegovu teoriju o društvu, zatim teoriju interakcije i na koncu teoriju diskursa. Weiss i Wodak (2003) s pravom ukazuju na to da je takvo stihijsko miješanje koncepata i kategorija utemeljilo jednu eklektičnu i nesistematičnu zbirku pojmova i kategorija. Međutim, spomenuti se eklekticizam često navodi kao jedna od najznačajnijih, pa čak i najvrjednijih osobina kritičke analize diskursa jer omogućuje istraživanje velikog broja društvenih problema i, što je možda ključno, ostavlja otvorenim proces eksperimentiranja spajanjem lingvističkih s društvenim istraživanjima. Iz istog je razloga problematično, odnosno 
teško sistematizirati programatske prijedloge o zasnivanju discipline jer navedene karakteristike i uvjeti koji valjaju biti zadovoljeni ne bi li se istraživanje moglo smjestiti u okvire kritičke analize diskursa variraju od istraživača do istraživača. Svaki od osnivača kritičke analize diskursa sastavlja vlastiti popis od desetak najznačajnijih karakteristika koje moraju obilježavati kritičko istraživanje diskursa, pri čemu naglašavaju različite aspekte kritičke analize diskursa, ali u skladu s vlastitim znanstvenim preokupacijama. Ovakva gotovo nemoguća heterogenost tog istraživačkog programa ponukala je Teuna van Dijka (1993) da kritičku analizu diskursa okarakterizira kao, u najboljem slučaju, jednu zajedničku perspektivu o tome kako raditi diskurzivnu analizu. Spomenutu je heterogenost možda najjednostavnije odredila Ruth Wodak (2003) koja tvrdi da je kritičku analizu diskursa najbolje zamisliti kao grubo skicirani istraživački program, a ne kao jasno definiranu, monolitnu istraživačku metodu. Wodak (2003) kaže da spomenutu nedefiniranost možemo djelomično pripisati njezinu relativno kasnom osnivanju, ako imamo na umu da je ona pod nazivom kritičke analize diskursa prisutna kao istraživački pristup tek tridesetak godina. Također, predstavnici kritičke analize diskursa (Fairclough 2003, Kendall 2007, van Dijk 2001) podržavaju njezinu fleksibilnost i prilagodljivost, zbog koje taj istraživački program nadilazi stroge podjele između kvalitativnih i kvantitativnih istraživanja te je neopterećen razdiobom na mikro ili makropristupe. Ruth Wodak (Kendall 2007) zato ističe da svojstvo minimalne zadanosti u odabiru predmeta istraživanja, materijala za analizu i konkretnih lingvističkih konceptualnih alata omogućuje istraživanje širokog raspona društvenih pitanja kojima se naknadno prilagođavaju metode analize teksta. Međutim, moguće je identificirati i izložiti neke osnovne karakteristike kritičke analize diskursa koje čine pozadinu provedenih istraživanja.

Među prvim nastojanjima da se kritička analiza diskursa izdvoji, opiše i razgraniči kao zasebna disciplina, nalazimo rad Gunthera Kressa (1990). Kress se usredotočuje na razgraničenje kritičke analize diskursa od drugih usmjerenja s područja lingvističkih istraživanja, pa se njegov niz obilježja kritičke analize diskursa pretežito fokusira na kritičko diskurzivni pogled na jezik, korisnike jezika i proizvodnju teksta. Kress (1990: 85-86) navodi deset kriterija koji obilježavaju rad u okviru ,paradigme kritičke analize diskursa“:

1. Jezik se shvaća kao oblik društvene prakse. On pripada nizu drugih „društvenih praksi reprezentacije i označivanja“, poput na primjer sustava gesti, slika ili glazbe. U zapadnjačkoj je civilizaciji jezik predmet opsežnih teoretizacija te je jedan od najbolje opisanih semiotičkih sustava. 
2. Predmet proučavanja kritičke analize diskursa je tekst kao proizvod društvenih aktera, odnosno pisaca i govornika koji djeluju unutar društvenog konteksta. Ti društveni akteri pri stvaranju teksta imaju na raspolaganju izbore o načinu izražavanja, ali samo unutar postojećih odnosa struktura moći i dominacije.

3. Kritička analiza diskursa pretpostavlja nejednake odnose moći između aktera koji sudjeluju u diskursu. Ti se odnosi nejednakosti nalaze na kontinuuma dvaju hipotetskih ekstrema potpune jednakosti („dimenzija solidarnosti“) i potpune nejednakosti (,dimenzija moći“).

4. Čitatelji ili slušatelji sudjeluju u procesu stvaranja značenja, koje je rezultat njihovog odnosa kako s tekstom tako i s govornicima i piscima tekstova te odnosa moći koji vladaju u toj interakciji. Značenje je također pod utjecajem pravila proizvodnje tekstova kao što su na primjer, pravila žanra.

5. Za razliku od strukturalizma, u okviru kritičke analize diskursa, lingvistički oblici kao što su znakovi, nisu nastali proizvoljnim spajanjem označenika i označitelja, već su proizvod njihova smislenog udruživanja u kontekstu društvenih procesa.

6. Jezik, a i tekstovi nisu transparentni, već njihovo značenje ovisi o lingvističkom i društvenom kontekstu.

7. Korisnici jezika su društveno smješteni pojedinci koji nemaju pristup cjelokupnom „sustavu jezika“, već su u mogućnosti koristiti pojedine dijelove tog sustava s obzirom na vlastiti društveni položaj. Svaki korisnik jezika u interakciji ima jedinstven pogled na jezik koji koristi, i jedinstveno znanje o jeziku i tekstu koje unosi u svoje konverzacije i korištenje jezika.

8. Kritička analiza diskursa problematizira jezik kao „sustav“.

9. Kritička analiza diskursa proučava jezik uzimajući u obzir njegov historijski aspekt, pri čemu se može govoriti o mikropovijesti pojedinog komunikacijskog događaja, ili makropovijesti društveno-jezičnih institucija.

10. Kritička analiza diskursa uvijek se oslanja na analizu „materijalnosti jezika“, to jest, ona zahtijeva detaljnu lingvističku analizu jezika u uporabi, a ne apstraktnog jezika.

Daljnji su pokušaji opisivanja i razgraničavanja discipline bili usredotočeni na definiranje zajedničkih pretpostavki i karakteristika koje bi omogućili stavljanje heterogenih istraživanja pod zajednički nazivnik kritičke analize diskursa. Rezime osnovnih principa ponudili su Norman Fairclough i Ruth Wodak (1997), čiji je tekst postao referentan pri 
opisivanju teorijskih postavki tako eklektičnog pristupa diskurzivnom istraživanju kao što je to kritička analiza diskursa.

\section{Orijentacija na društvene probleme}

Istraživanja u okviru kritičke analize diskursa pokušavaju rasvijetliti diskurzivni aspekt nekog temeljnog, neriješenog konflikta u društvu. Cilj kritičke analize nije samo proučavanje jezika i korištenja jezika, već usredotočenost na „lingvistički karakter društvenih i kulturnih procesa i struktura“ (Fairclough i Wodak 1997: 271). Pri proučavanju društvenog problema prihvatljivo je koristiti niz različitih teorijskih i metodoloških pristupa za koje istraživač procijeni da su učinkoviti u rasvjetljavanju relevantnih aspekata procesa društvenih promjena u kasnoj modernosti poput globalizacije ili novog kapitalizma (Fairclough 2003) te društvenih nejednakosti poput rasizma, nacionalizma ili seksizma (van Dijk 1995).

\section{Analiza društvenog konteksta}

Kritička analiza diskursa sadrži istraživanja koja se zasnivaju na proučavanju konkretnih komunikacijskih događaja, koji se sastoje od lingvističkog i društvenog aspekta, odnosno koji predstavljaju korištenje jezika u različitim društvenim situacijama. Diskurs je također smješten u određenu povijesnu matricu, to jest, „diskurs nije proizveden bez konteksta i ne može biti shvaćen, ako u obzir ne uzimamo kontekst" (Fairclough i Wodak 1997: 276). Kritičko istraživanje diskursa se širi izvan područja lingvističke analize samog teksta kao momenta artikulacije u interakciji korisnika jezika, i to na širi društveno-povijesni kontekst.

\section{Povezanost diskursa i društvenih procesa}

Svi društveni fenomeni i procesi imaju svoju lingvističko-diskurzivnu dimenziju. Svaki je diskurs ujedno i oblik društvene akcije. Diskurs je oblik društvene prakse koji konstituira društvo i kulturu, ali je on ujedno i konstituiran. Društvene pojave, koje nemaju isključivo diskurzivni karakter, kao što su na primjer struktura političkog sustava ili institucionalna struktura medija, povratno konstituiraju sami diskurs. Zato možemo reći da između diskursa kao društvene prakse i drugih društvenih praksi postoji dijalektički odnos. Osim što diskurs sudjeluje u oblikovanju različitih društvenih praksi, on također i odražava njihove karakteristike. „U kritičkoj analizi diskursa, jezik kao diskurs je ujedno oblik djelovanja kroz koji ljudi mogu mijenjati svijet $i$ oblik djelovanja koji je društveno i povijesno smješten i u dijalektičkoj vezi s drugim aspektima društvenoga“ (Jørgensen i Phillips 2002: 62). Fairclough i Wodak (1997) također naglašavaju da je veza između teksta i društva posredovana, pa se zato u kritičkoj analizi diskursa ,uspostavljaju veze između društvenih i kulturnih struktura i procesa 
s jedne strane, i svojstava teksta s druge strane“ (Fairclough i Wodak 1997: 277). Koncept pomoću kojega Fairclough uspostavlja analitičku vezu između teksta i društva je Foucaultov „poredak diskursa“ koji predstavlja niz različitih diskurzivnih oblika ili praksi vezanih uz pojedinu instituciju. Na primjer zdravstvene institucije poput bolnica imaju svoj poredak diskursa koji se sastoji od konzultacija liječnika s pacijentima, kartona pacijenata, financijskih izvještaja, sastanaka rukovoditelja, i tako dalje.

\section{Odnosi moći u društvu su diskurzivne prirode}

U kritičkoj analizi diskursa ideologija se ostvaruje kroz diskurs. Ideologije su „posebni načini predstavljanja i konstrukcije društva koji reproduciraju nejednake odnose moći, odnose dominacije i eksploatacije“ (Fairclough i Wodak 1997: 275). Diskurs nije neutralan već djeluje na način da podržava ili potiskuje određene konstelacije ideja čime doprinosi nejednakoj raspodjeli moći u društvu. Kritička se analiza diskursa bavi proučavanjem diskurzivnih praksi koje facilitiraju određene ideologije održavajući odnose nejednakosti u društvu, kao i diskurzivnih praksi koje postavljaju izazove pred pretpostavljeni status quo u društvu i usmjeravaju društvo k promjenama.

\subsection{Utemeljenje društvenog angažmana u kritičkoj analizi diskursa}

Kritička analiza diskursa zadržava kontinuitet s kritičkom lingvistikom nastojeći povezati lingvističko istraživanje teksta kao osnovne analitičke jedinice, sa sviješću o društveno-lingvističkoj međuuvjetovanosti diskurzivne produkcije. Kao kritička, ova se analiza diskursa može povezati s mnogobrojnim istraživanjima koja čine cjelokupnu tradiciju kritičkih istraživanja, a koja su uostalom i prisutna kao teorijske podloge istraživačima kritičke orijentacije unutar analize diskursa. Među školama istraživanja na koje se oslanjaju pojedini istraživači u kritičkoj analizi diskursa nalazimo neomarksizam, Frankfurtsku školu te zapise Jurgena Habermasa. Osim navedenih teorijskih usmjerenja, kritički je naglasak potekao i iz područja književne kritike, zatim iz Foucaultove arheologije, kao i postmodernizma, poststrukturalizma i dekonstrukcije (Locke 2004). U kritičkoj analizi diskursa, termin „kritički“ ima vrlo široki raspon značenja pri čemu ta raznolikost ne čudi kada se uzme u obzir brojnost navedenih teorijskih izvora koji se i sami međusobno razlikuju u svojim kritičkim pristupima. Ako uzmemo samo Frankfurtsku školu, uvidjet ćemo da postoje razilaženja u koncepcijama njoj pripadajućih znanstvenika oko toga što se zapravo podrazumijeva pod pridjevom „kritički“. Međutim, moguće je izdvojiti neke općenite karakteristike koje se mogu pridati 
gotovo svim kritičkim teorijama i istraživanjima. Kincheloe i McLaren (2005: 304) sastavili su jedan takav popis karakterističnih pretpostavki kritičke perspektive:

a) fundamentalna je oznaka svega znanja da je ono posredovano kroz odnose moći koji imaju specifičan društveno-historijski kontekst,

b) činjenice su uvijek isprepletene s vrijednostima i ne mogu biti zaštićene od utjecaja pojedinih ideologija,

c) odnosi između koncepta i objekta te društva i jezika, odnosno između označitelja i označenika nisu stabilni, već na njih utječu društveni odnosi kapitalističke proizvodnje i potrošnje,

d) jezik je središnja kategorija kada govorimo o oblikovanju subjektiviteta,

e) određene su skupine u društvu privilegirane u odnosu na druge, a razlozi te privilegiranosti mogu biti različiti. Ta se nejednakost u suvremenim društvima najuspješnije perpetuira kada oni koji su podređeni prihvaćaju svoj status kao prirodan i neizbježan,

f) nejednakost i ugnjetavanje imaju mnogo aspekata, od kojih su mnogi međusobno povezani, kao na primjer, klasno ugnjetavanje s rasnim. Istraživači koji se usredotočuju na isključivo jednu vrstu ugnjetavanja propuštaju istražiti spomenutu povezanost,

g) „mainstream“ istraživanja se u kritičkoj istraživačkoj tradiciji smatraju (često nenamjernim) sudionicima u reproduciranju klasnih, rasnih te rodnih sustava nejednakosti i opresije.

Kritička analiza diskursa preuzela je na sebe ciljeve istraživanja koji su u određenoj mjeri u skladu s navedenim kritičkim pretpostavkama i koji podrazumijevaju povezivanje društvenog angažmana s konstrukcijom društva, ali bez nastojanja da se provodi društveni inženjering (Fairclough 1995). Fairclough (1995) opisuje kako je za komunikaciju potrebno „pretpostavljeno znanje“ (eng. background knowledge) koje sudionici u interakciji uzimaju zdravo za gotovo, a to pretpostavljeno znanje uključuje i mnoge ideološke reprezentacije na koje se gleda kao na neideološke i zdravorazumske istine jer u pretpostavljenom znanju ideologije postaju naturalizirane. Ruth Wodak (Kendall 2007) na sličnom tragu navodi kako se u najopćenitijem smislu pridjev „kritička“ može shvatiti kao odbijanje uzimanja stvari zdravo za gotovo ili kao „otvorenost za alternativna čitanja“, kao razotkrivanje ideoloških pozicija u tekstu, a uz navedeno i kao autorefleksivnost $\mathrm{u}$ istraživačkom procesu. 
Polazeći od pozicija koje je u svojim radovima navodila Wodak (2001), Terry Locke (2004) je opisao kritičnost u analizi diskursa na tri razine: kritika kao razotkrivanje, kritička praksa kao autorefleksivnost i kritička praksa kao društvena transformacija. U opisivanju „kritičkog“ kao vrste razotkrivanja, Locke (2004) se osvrće na Foucaultov rad koji je „smjestio 'kritičko' u sistematični, analitički poduhvat otkrivanja prirode sustava pravila, principa i vrijednosti kao povijesno smještenom temelju za kritiku. On je nazvao tu analizu arheologijom i njezin proizvod genealogijom; njegov je ključni pojam diskurs“ (Locke 2004: 27). Uspostavljanjem analize koju naziva arheologijom, Foucault je postavio izazove dotadašnjem shvaćanju povijesti ideja, čime je uspostavio temeljne ključne koncepte koji će se kasnije koristiti, mada u donekle izmijenjenom obliku, u kritičkoj analizi diskursa. Ono što se smatra kritičkim u kontekstu Foucaultove arheološke metode može se po Lockeu (2004) razložiti na četiri kritičke primjedbe usmjerene prema tradicionalnim pristupima povijesti ideja pri čemu Foucault nanovo promišlja neke već etablirane koncepte za koje uspostavlja novi diskurzivni aspekt. Foucault tako u prvom redu propituje granice „područja diskursa“ pri čemu kritizira tezu o nemogućnosti razgraničenja značenja koja proizvode diskursi; on dovodi u pitanje pretpostavku o subjektu koji stvara značenje, o autoru teksta te ga „transkribira u diskurs“, i smatra da subjekt valja shvatiti kao diskurzivno konstituirani entitet; te naposljetku smatra da diskurs nema vremenski kontinuitet, već je moguće odrediti prostore nastanka i nestanka diskursa (Locke 2004). Druga se kritika odnosi na binarne opozicije kao što su primjerice staro i novo, statično i dinamično, otvoreno i zatvoreno, pri čemu smatra da one nisu jasne i nepromjenjive, kao što to između ostalog tvrdi i poststrukturalizam. Treća, a po Lockeu (2004) najvažnija kritika, odnosi se na problem negiranja diskursa što podrazumijeva tretiranje diskursa samo kao „mjesta gdje se izražavaju misli, zamišljanja, znanja i nesvjesne teme“, viđenje diskursa kao proizvoda psihološke konstitucije njegova autora, ili proizvoda pojedinog žanra i stila, ili teme te pretpostavljanje da sve aktivnosti prethode diskursu i odvijaju se izvan njega. Na kraju, Foucault predlaže da se povijest ideja, zbog sebi svojstvenih neodređenosti zamijeni proučavanjem samog diskursa $u$ njegovu nastanku, razvoju i transformaciji te opisivanju odnosa s drugim praksama kao što su političke prakse. Locke (2004) je ukratko opisao kritički sadržaj Foucaultove diskurzivne metode, koji je izvršio utjecaj na kritičku analizu diskursa, međutim, postoje i drugačija shvaćanja kritike kao razotkrivanja, pa tako Ruth Wodak (2001) smatra da do kritičkog stava ili razotkrivanja dolazi kada se počnu propitivati pozicije koje se uzimaju zdravo za gotovo, odnosno kada dolazi do otkrivanja da su diskursi zapravo naturalizirani kod pojedinaca i da oni promatraju svijet kroz prizmu određenih diskursa za koje smatraju da su zdravorazumski. U kritičkoj se analizi diskursa ukazuje na različite vrste 
nejednakosti među ljudima koje su naturalizirane i koje se smatraju prirodnima i nepromjenjivima, a za takvu vrstu naturalizacije odgovornim se smatraju slojevi društva koji pomoću naturaliziranih diskursa zadržavaju svoj povlašteni položaj u društvu. U tom je smislu ovaj pogled bliži marksističkome poimanju ideologije kao odraza odnosa moći koji potječe o partikularnih interesa određenih društvenih skupina. Foucault je oprezan prema pojmu ideologije, kojeg u svojoj analizi kritizira i u određenoj mjeri zamjenjuje pojmom diskursa, zato što ideologija implicira postojanje nekog stabilnog centra moći te „superiorne“ kritičke pozicije izvan diskursa koja može razotkriti njezino djelovanje. Unatoč tome, istraživači koji se bave kritičkom analizom diskursa, spajaju Foucaultove pojmove sa marksističkima, pa se tako Fairclough (1995, 2003), uz dijelove Foucaultove analize oslanja i na Althusserov pojam ideologije i državnog aparata.

Kritička praksa kao autorefleksivnost, konstrukt je koji potječe od modernog skepticizma nastalog pod snažnim utjecajem poststrukturalizma. Poststrukturalizam je potkopao dotadašnje povjerenje u velike narative i uveo predodžbu o višestrukosti perspektiva na različita životna pitanja, koje se „sudaraju jedno s drugim u kaleidoskopskom melanžu podložnom brzoj hibridizaciji i pastišu“ (Locke 2004: 34). Dekonstrukcija Jacquesa Derride pokazala je da su značenja tekstova neodrediva te se usredotočila na povijesnu smještenost tekstova, njihovu nekoherentnost i mnogostrukost verzija realnosti sadržanih u tekstu. Ti su trendovi na neki način nametnuli potrebu da se istraživači koji rade u kritičkoj tradiciji istraživanja, kritički odrede i prema vlastitom radu ne bi li prema riječima Kincheloea $i$ McLarena (2005) osvijestili ideološke imperative u svojim istraživanjima te vlastite subjektivne ili normativne tvrdnje. Autorefleksivnost se po Kincheloeu i McLarenu (2005) može shvatiti na dva načina. Kao prvo, istraživači kritičke tradicije trebaju se suočiti s time da je njihova metoda također društveno konstruirana te da su sva značenja koncepata na koje se oslanjaju u istraživanjima, ma koliko ona bila ,zdravorazumska“, diskurzivno konstruirana. S druge strane, istraživači se trebaju suočiti s time da se rezultati njihovih istraživanja prihvaćaju samo uvjetno.

Kritička praksa kao aktivnost transformiranja društva zasniva se na pretpostavci da $u$ društvu postoje nejednakosti u moći koje se preslikavaju i na diskurs i diskurzivne prakse, jer neki društveni akteri nemaju pristup svim oblicima diskurzivnih praksi te također, prema kritičkoj analizi diskursa, oblikuju svoje komunikacijsko djelovanje pod utjecajem dominantnih diskursa prisutnih u diskurzivnim praksama putem kojih moćniji akteri imaju više prilike utjecati na sadržaj diskursa. Locke (2004) kaže da nisu svi diskursi jednako moćni te da moć diskursa ovisi o društvenom statusu aktera koji u njemu sudjeluju. Društveni akteri koji djeluju 
putem diskursa koji nemaju preveliku moć zapravo su marginalizirani. Kritički se orijentirani istraživači priklanjaju onim političkim nastojanjima koja pokušavaju promijeniti tu neuravnoteženu raspodjelu moći među diskursima. U okviru kritičke analize diskursa, sudjelovanje $\mathrm{u}$ aktivnostima transformacije društva podrazumijeva zauzimanje stava o nejednakostima između društvenih aktera na temelju etničkih, nacionalnih, rasnih, rodnih ili klasnih razlika te nastojanje da se kritičkim razumijevanjem omoguće uvjeti za društvenu promjenu. Ne bi li doprinijela postizanju cilja društvene promjene, kritička se analiza diskursa usredotočuje na proučavanje odnosa moći koji se održavaju ili mijenjaju proizvodnjom, konzumacijom i širenjem tekstova.

\subsection{Značenje diskursa}

Pri pokušajima definiranja diskursa, moramo osvijestiti da je „diskurs“ jedan od pojmova s teško uhvatljivim jednosmislenim značenjem jer se koristi prilično često i u mnogim vrlo različitim kontekstima. Svoju značenjsku fleksibilnost i neuhvatljivost diskurs može zahvaliti svojoj akademskoj popularnosti. Pojam diskursa koristi se u znanstvenim disciplinama kao što su filozofija, sociologija, lingvistika, kritička teorija ili socijalna psihologija, a da se pritom njegovo značenje često pretpostavlja pa se prilikom korištenja rijetko i definira. Ne bi li zadovoljavajuće ocrtala obrise diskursa i ocrtala neuhvatljivo značenje tog pojma, Sara Mills (2004) je nastojala mapirati teorijske kontekste uporabe pojma diskursa. Značenje riječi „diskurs“ ovisi o disciplinarnom kontekstu u kojemu se on koristi, dok je čak i u istoj disciplini za pojam diskursa karakteristična mnogostrukost značenja.

Pri određivanju značenja riječi diskurs, jedno je od mogućih rješenja opisivanje onoga što diskurs nije, pa tako teoretičari kao kontrast diskursu uzimaju pojmove kao što su rečenica, tekst, jezični sustav ili ideologija (Mills 2004). U lingvistici se pod istraživanjem diskursa podrazumijeva ono istraživanje koje za svoju temeljnu jedinicu analize uzima cjelinu koja je iznad rečenice, koja je, jednostavno rečeno, komad teksta. Međutim, lingvisti naglašavaju potrebu za razlikovanjem diskursa i teksta, pa je tako David Crystal (Mills 2004) pokušao definirati diskurs u lingvistici kroz njegovo razlikovanje od teksta navodeći da se:

„Analiza diskursa usredotočuje na strukture govornog jezika koji se koristi spontano, koji nalazimo u takvim 'diskursima' kao što su konverzacije, intervjui, komentari i govori. Analiza teksta se usredotočuje na strukturu pisanog jezika, koji nalazimo i takvim 'tekstovima' kao što su eseji, obavijesti, prometni znakovi ili poglavlja. Međutim ta razlika nije sasvim razvidna te se te dvije navedene oznake 
koriste na različite načine. Osobito se 'diskurs' i 'tekst' mogu koristiti u mnogo širem smislu ne bi li uključili sve jezične jedinice s jasnom komunikacijskom funkcijom, bile one pismene ili usmene. Neki znanstvenici govore o 'pismenom ili usmenom diskursu', drugi o 'pismenom ili usmenom tekstu."“ (Crystal 1987; prema Mills 2004: 3).

U lingvistici je također prisutno definiranje diskursa kroz usporedbu s jezičnim sustavom, pri čemu se jasno daje do znanja da u domeni analize diskursa, lingvisti problematiziraju i napuštaju pojam 'jezičnog sustava', kao središta njihova istraživanja. Emile Benveniste kaže:

„Rečenica, nedefinirana kreacija bezgranične raznovrsnosti, je sam život ljudskog govora u akciji. Iz toga možemo zaključiti da s rečenicom mi napuštamo domenu jezika kao sustava znakova i ulazimo u drugi svijet, u svijet jezika kao instrumenta komunikacije, čiji je izražaj diskurs.“ (Benveniste 1971; prema Mills, 2004: 4).

Kritički lingvist Roger Fowler jedan je od teoretičara koji nastoje ukazati na značenje diskursa razlikujući diskurs i ideologiju i to na sljedeći način:

„Diskurs je govor ili pisanje viđeno iz perspektive vjerovanja, vrijednosti i kategorija koje utjelovljuje; ta vjerovanja konstituiraju način pogleda na svijet, organizaciju ili reprezentaciju iskustva - 'ideologiju' u njezinom neutralnom smislu koje nije pejorativno. Različiti oblici diskursa kodiraju različite reprezentacije iskustva; i izvor tih reprezentacija je komunikacijski kontekst unutar kojega je smješten diskurs.“ (Hawthorn 1992; prema Mills 2004: 5).

Korištenjem pojma „diskursa“ u okvirima strukturalističke i poststrukturalističke misli došlo je do temeljnog preokreta u shvaćanju jezika i reprezentacije. Dok su ranija istraživanja jezika upućivala na njegovu navedenu temeljnu funkciju transparentnog komuniciranja i prenošenja informacija i funkciju reprezentacije, strukturalisti i poststrukturalisti su vidjeli jezik kao sustav s vlastitim pravilima, mogućnostima i ograničenjima koja utječu na društvene aktere. Pri definiranju ,diskursa“, Mills (2004) ističe kako čak i usporedbom diskursa s drugim uvriježenim terminima, ili pregledom pripisanih značenja „diskursu“ u rječnicima, teško možemo doći do jasnog određenja jer se u pronađenim definicijama zrcali fluidnost tog pojma koja je rezultat njegova kompleksnog povijesnog razvitka i kaotičnog korištenja unutar pojedinih disciplina, pa čak i u pisanjima pojedinih teoretičara. Sam se Foucault (2002: 90) po tom pitanju odredio podupirući tu karakterističnu višeznačnost: 
„Umjesto da sam postupno reducirao podosta fluktuirajuće značenje riječi 'diskurs', vjerujem da sam zapravo učinio dodatke njezinu značenju; ponekad je tretirajući kao opće područje svih izjava, ponekad kao individualiziranu skupinu izjava, i ponekad kao reguliranu praksu koja se odnosi na određeni broj izjava“‘.

Mills (2004) na temelju Foucaultova (2002) citata izvodi tri definicije diskursa koje se pojavljuju u njegovim radovima. Najšira Foucaultova definicija diskursa je ona po kojoj on podrazumijeva sve tekstove ili usmene izjave koje imaju neko značenje i koje utječu na zbilju. Tu definiciju Foucault koristi u svojim ranijim, strukturalističkim radovima koji se bave diskursom na apstraktnoj teorijskoj razini i u tom se značenju diskurs upotrebljava u jednini. Diskurs kao „individualizirana skupina izjava“ odnosi se na Foucaultove kasnije analize specifičnih struktura pri čemu on nastoji identificirati diskurse kao „skupine izjava koje su na neki način regulirane i koje imaju određeni stupanj koherentnosti i zajedničke sile“ (Mills 2004: 6). U tom smislu možemo razlikovati na primjer, diskurs imperijalizma ili diskurs ženstvenosti. Mills (2004) procjenjuje da je Foucaultova treća definicija diskursa ta koja se najčešće upotrebljava među teoretičarima, i ona opisuje diskurs kao ,reguliranu praksu koja se odnosi na određeni broj izjava“, pri čemu se Foucault fokusira na pravila i strukture koje utječu na stvaranje određenih usmenih izjava i tekstova. Prema tome, za Foucaulta su diskursi skupine izjava koje su regulirane pravilima specifičnima za određeni diskurs ili one mogu biti regulirane kroz odnose koje imaju s drugim diskursima. S obzirom na to da je potonja definicija u velikoj mjeri utjecala na mnoga druga teorijska shvaćanja diskursa valja pojasniti što se podrazumijeva pod sintagmom „diskurzivnih struktura“ koje uvjetuju i utječu na proizvodnju diskursa. Sara Mills (2004) u tom kontekstu raspravlja o „mreži praksi“ koja konstituira sami diskurs i predstavlja „,apstraktni element" unutar kojeg nastaju diskursi. Diskurs kao cjelinu tvore regulirani diskursi koji se vode sebi svojstvenim pravilima i pod utjecajem su takozvanih diskurzivnih struktura. U diskurzivne strukture u kojima se gradi diskurs spadaju pojmovi kao što su episteme, izjava, diskurs/diskursi i arhiv. Diskurs se dakle sastoji od reguliranih diskursa koji se pak sastoje od izjava (eng. statements) koje su u Foucaultovom teorijskom okviru gradbeni elementi diskursa. Izjave su za Foucaulta ono govorenje koje ima neku institucionalnu snagu i u čijoj se pozadini nalazi neki oblik autoriteta. To je onaj govor koji se u kontekstu jadne episteme može smatrati ,istinitim“. Epistema je jedna apstraktna konstrukcija koju mnogi uspoređuju s Kuhnovom paradigmom, ali ona u kontekstu rasprave o diskursu predstavlja cijeli komplet diskurzivnih struktura kao cjeline te u njoj neka forma kulture, bila ona nacionalna, lokalna ili organizacijska, formulira svoje ideje (Mills 2004). Dok raspravlja o diskursu, kod Foucaulta je karakteristična izmjenjivost dvojakog 
značenja tog pojma, pa tako postoji diskurs kao cjelina koji podrazumijeva skup pravila $\mathrm{i}$ procedura koje određuju proizvodnju diskursa te diskurse koje predstavljaju skupine izjava. Sara Mills (2004), oslanjajući se na Foucaultov teorijski rad, definira diskurs kao „set sankcioniranih izjava koje imaju određenu institucionaliziranu snagu, što znači da imaju veliki utjecaj na način na koji individue djeluju i na koji način razmišljaju. Nejasno je kako se mogu odrediti granice diskursa. Međutim, možemo reći da su diskursi skupine izjava koje imaju sličnu snagu - to jest, one su grupirane zajedno zbog nekog institucionalnog pritiska, zbog neke sličnosti provenijencije ili konteksta, ili zato što djeluju na sličan način“ (Mills 2004: 55-56).

Sve navedene definicije ne isključuju jedna drugu već se često koriste naizmjenično u radovima znanstvenika, a njihova se značenja uvelike preklapaju. Osim Foucaulta, diskursom su se bavili, između ostalih, i Mikhail Bakhtin i Roland Barthes, za koje diskurs može predstavljati i pojedini glas, autoritet unutar teksta, ili određenu poziciju nekoga tko govori (Mills 2004). Ono što je zajedničko većini pristupa navedenih teoretičara jest to što diskursu pridaju institucionalnu prirodu i što ga smještaju u okvire društvenoga. „Diskurs nije raskomadana zbirka izjava, već su to skupine izjava ili rečenica koje se stvaraju u društvenom kontekstu, koje taj društveni kontekst determiniraju i koje doprinose načinu na koji taj društveni kontekst nastavlja postojati““ (Mills 2004:10).

Michel Pecheux, marksistički je lingvist koji je svojim shvaćanjima diskursa također utjecao na razvoj kritičke analize diskursa. Pecheux (Mills 2004) naglašava povezanost diskursa i institucija jer smatra da diskursi nastaju i razvijaju se u dijalogu s drugim skupinama izjava, tj. diskursima. Diskurs tako najčešće nastaje kao reakcija, kritika ili opozicija određenom diskursu, kao što je na primjer slučaj s diskursom environmentalizma koji je nastao kao odgovor na strategije razvoja država i vlasti te kao reakcija na događaje prirodnih katastrofa koje su bile rezultat određenog modela gospodarskog razvoja. Iz tog razloga možemo reći da su se filozofije „zelenih“ razvile oviseći o okolnostima izvan njihova diskurzivna okvira, međutim jednako tako se može reći da su vladine politike bile usmjeravane pritiscima koji su dolazili od skupina environmentalista. Razlika Pecheuxova pogleda na diskurs u odnosu na Foucaultov, temelji se na njegovu naglašavanju ,konfliktne prirode diskursa: diskurs je uvijek u dijalogu i konfliktu s drugim pozicijama“ (Mills 2004). U srcu je diskursa ideološka borba. Pecheux također postavlja pitanje pristupa diskursu, ističući da pristup obrazovanju, znanju i socijalnom kapitalu nije svima dostupan i jednakoj mjeri, pa je tako mnogima pristup diskursu otežan. Kao primjer isključivanja iz diskursa može se navesti mogućnost osobe da objavljuje u akademskom časopisu. Iako je teoretski svakome omogućeno da objavljuje akademske članke, pristup je uvjetovan 
pridržavanjem formalnih pravila akademskog pisanja koja predstavljaju regulirajuće strukture akademskog diskursa. Osim tehničkih pravila koja se odnose na upotrebu odgovarajućeg rječnika, formalnog jezika, citiranja drugih renomiranih članaka, postoje i druga implicitna pravila koja zahtijevaju, primjerice, rad u nekoj od akademskih institucija, ili je li autor koji prijavljuje članak poznat uredništvu određenog časopisa. Mills (2004) navodi još dva aspekta diskursa koji su zajednički većini definicija koje koriste spomenuti teoretičari. Kao prvo, možemo reći da se suština diskursa - ono što on jest, zapravo temelji na praksama isključivanja, jer ono što je moguće reći unutar pojedinog diskursa određeno je prema onome što je iz njega marginalizirano i izbačeno. Druga karakteristika svih definicija je da se sve što ima značenje može smatrati dijelom diskursa. Iako se ova značajka čini prilično općenitom i neodređenom, ona upućuje na to da riječi i rečenice imaju vlastitu snagu i posljedice na društveni kontekst, a Pecheux primjerice, naglašava da se značenje riječi ili pojedinih izjava teškom može izvoditi iz njih samih već je za to potrebno dovođenje u vezu sa širim strukturama jer riječi i rečenice same po sebi nemaju fiksirano značenje.

Na kritičku je analizu diskursa kao i na mnoge druge discipline i teoretičare koji su preuzeli pojam „diskursa“ kao područje znanstvenog interesa i istraživanja, veliki utjecaj izvršio Foucault. I Fairclough je veliki dio svog pojmovnog aparata preuzeo od Foucaulta, ali ga je u određenoj mjeri modificirao na mjestima gdje se s njime razilazio u određenim teorijskim pitanjima. Naime, Faircloughova su istraživanja inspirirana, uvjetno rečeno marksističkom tematikom, pa je on svoj teorijski model nadopunjavao teorijama mislilaca marksističke orijentacije poput Michela Pecheuxa i Louisa Althussera. Fairclough također diskurs definira kroz više dimenzija, ali pretežito u okviru lingvističkih istraživanja i to za potrebe razvoja konceptualnog okvira kritičke analize diskursa. Ne bi li kritičku analizu diskursa izdvojio iz cjeline postojećih lingvističkih istraživanja, Fairclough (1996/1989) definira diskurs u najopćenitijem analitičkom smislu kao naprosto jezik u funkciji, to jest kao jezik koji je društvena praksa. Proučavanje diskursa je proučavanje jezičnog aspekta društvenog života; i dok su svi jezični fenomeni društveni, svi društveni fenomeni nemaju jezični aspekt. Za razliku od teksta koji je proizvod nekog stvaralačkog procesa, „diskurs je čitavi proces društvene interakcije čiji je tekst samo jedan dio“ (Fairclough 1996/1989: 24). Zato analiza teksta predstavlja samo jednu komponentu analize diskursa koja onda obuhvaća i procese proizvodnje i procese interpretacije, a tekstovi koji se analiziraju u sebi sadrže naznake o navedenim procesima. Diskurs definiran kao društvena praksa predstavlja pojam diskursa u najapstraktnijem smislu, koji u kasnijim radovima, Fairclough naziva semiozom. Diskurs u 
smislu semioze stoji u troznačnom odnosu s društvenim praksama i društvenim događajima. Diskurs može biti dio društvenog djelovanja ili neke društvene aktivnosti, pa je tako na primjer, dio obavljanja nekog posla i korištenje jezika u skladu s nekom društvenom ulogom, kao što je na primjer posao financijskog savjetnika ili posao sindikalnog povjerenika. Diskurs je također povezan s reprezentacijama. „Društveni akteri koji djeluju u bilo kojem području ili organizaciji stvaraju reprezentacije drugih praksi, kao i ('refleksivne') reprezentacije vlastitih praksi, tijekom obavljanja svojih aktivnosti, i različiti društveni akteri će ih predstavljati različito prema tome kako su pozicionirani unutar područja i organizacija“" (Fairclough 2003: 206). Naposljetku, diskurs sudjeluje u oblikovanju identiteta. Na primjer, identitet političkog vođe je djelomično određen jezičnim praksama. Kao dio društvene aktivnosti diskurs konstituira žanrove, a žanrovi predstavljaju različite oblike interakcije. Interakcija se može odvijati preko žanrova kao što su novinski članci, intervjui, knjige, video izvještaji, ili recimo sastanci u različitim organizacijama. Kada u apstraktnom smislu govorimo o diskursu on podrazumijeva i zasebne diskurse koji su reprezentacije društvenih praksi, odnosno društvenog života. Pri opisivanju života rudara moguće je osloniti se na različite diskurse iz društvenih praksi politike, ekonomije, društvenih znanosti, vlade, sindikata, kao i diskurse aktera u spomenutim praksama koji zauzimaju različite pozicije.

\subsection{Ideologija i hegemonija u kritičkoj analizi diskursa}

Kritička analiza diskursa analizira tekstove u kontekstu diskurzivnih i društvenih praksi s ciljem ukazivanja na društvene konflikte i ulogu moći u strukturi poredaka diskursa koji određuju sadržaj i oblik tekstova. Osnovna premisa kritičke analize diskursa je ta da je analizom teksta moguće prepoznati strukturu odnosa moći u društvu. Ključni koncept pomoću kojeg kritička analiza diskursa nastoji objasniti tu (među)ovisnost teksta i društvenih praksi jest poredak diskursa. Poredak diskursa predstavlja strukturu diskurzivnih tipova (žanra, diskursa i stila) koja postavlja ograničenja na to što je moguće reći u svakom pojedinom tekstu. U kritičkoj analizi diskursa koriste se različita analitička sredstvima koja primjenjujemo na pojedinačne tekstove kako bismo razotkrili odnose moći u društvu, uzimajući u obzor specifičnosti svakog pojedinačnog istraživačkog problema. Zbog utjecaja poredaka diskursa na stvaranje i oblikovanje pojedinačnih tekstova možemo pretpostaviti da analizirani tekstovi zrcale raspodjelu i odnose moći u društvu. Nejednakosti u raspodjeli moći u društvu moguće je tražiti u odnosu koji postoji između teksta, odnosno diskursa, i ideologije koja stoji u pozadini njegova oblikovanja. Ono što je neuobičajeno kod teorijske pozadine kritičke analize diskursa jest to što se ona oslanja i na koncept ideologije i na koncept diskursa; na koncept ideologije preuzet iz 
marksizma i koncept diskursa kako ga je zamislio i razradio Foucault u svojim istraživanjima između ostalog i da bi na neki način zaobišao korištenje koncepta ideologije.

U kritičkoj analizi diskursa koriste se dva u nekim teorijskim tradicijama nespojiva pojma ideologije i diskursa zbog toga što su u teorijskoj konceptualizaciji te discipline prisutne dvije linije podrijetla koncepta diskursa (Talbot 2007). Prvo shvaćanje diskursa potječe iz lingvističke tradicije gledanja na diskurs kao na ono što je iznad teksta, odnosno kao na cjelokupan društveno uvjetovani proces nastanka teksta koji je motiviran i određen raspodjelom moći u društvu pri čemu je ključan pojam ideologije. S obzirom na to da je u kritičkoj analizi diskursa važno odrediti i razotkriti relativne odnose moći određenih društvenih skupina (,opipljiviji“ zadatak od onoga na koji cilja Foucault), koncept ideologije potreban je kako bi se to ostvarilo. Sama teorija diskursa ne daje konkretne mogućnosti za kritiku uspostavljenog društvenog i diskurzivnog poretka. Ako kao primjer uzmemo istraživanje medijskog diskursa, onda je važno istaknuti ulogu medija kao „meta-instance“ proizvodnje diskursa pri čemu treba razlučiti između moći medija i moći onih od kojih diskursi primarno potječu, pa i samih izvora kritike o medijskoj proizvodnji sekundarnih diskursa, što nije lak zadatak ako je teorija diskursa jedino na što se možemo osloniti (Macdonald 2003). Kritička analiza diskursa ima prioritet raspoznati i aktivno mijenjati odnose moći u društvu pa iz tog razloga funkcionira na temelju premise da diskursi funkcioniraju ideološki jer, između ostalog, i same „diskurzivne prakse pridonose stvaranju i reprodukciji nejednakih odnosa moći između društvenih grupa - na primjer, između društvenih klasa, žena i muškaraca, etničkih manjina i većine“ (Jørgensen i Phillips 2003: 63). Kritička analiza diskursa sadrži marksističku perspektivu na djelovanje moći u društvu jer pretpostavlja da u društvu postoje skupine koje su podređene i skupine koje su moćnije. Međutim, i Foucaultova je teoretizacija moći kao produktivne sile koja konstituira subjekte, ali koja se ne može posjedovati od subjekata; koja nije pod potpunom kontrolom subjekta, također uvažena. „Prema tome, žarište istraživanja kritičke analize diskursa jesu $i$ diskurzivne prakse koje konstruiraju reprezentacije svijeta, društvene subjekte i društvene odnose, uključujući i odnose moći, $i$ uloga koju te diskurzivne prakse imaju u promicanju interesa određenih društvenih skupina“ (Jørgensen i Phillips 2003: 63).Dakle, sinkretizam ideologije i diskursa jedna je od idiosinkrazija kritičke analize diskursa koja potječe iz spajanja perspektiva poststrukturalizma i marksističke teorijske orijentacije, i koja se može pripisati specifičnom razvoju same discipline. Ishodište kritičke analize nalazimo u kritičkoj lingvistici koja se povezala s kritičkom društvenom teorijom u svojim nastojanjima da se pri analizi tekstova usredotočuje na društveni kontekst te međuodnose utjecaja tekstova i njihova 
društvena okruženja koji se odvija preko ideologije. Iz područja je lingvistike tako preuzet pojam diskursa kao, pojednostavljeno rečeno, analize teksta u društvenom kontekstu, odnosno napuštanja koncepcije jezika kao izoliranog sustava i etabliranje linije istraživanja u okviru lingvističke znanosti koja se bavila jezičnim konstrukcijama koje su nadređene jezičnoj jedinici rečenice. S druge strane, zbog nesustavnog korištenja pojma diskursa, ali i zahtjeva istraživanja koje si za cilj postavlja utvrđivanje odnosa moći koji se zrcale u tekstovima, u kritičku analizu diskursa pristižu primjese Foucaultovih istraživanja koje je pak u mnogočemu postavljeno na temelju distanciranja od dotadašnjih marksističkih teorija o društvu. Međutim, iako je Foucault razvijao svoj pojam diskursa kao njemu prihvatljiviji teorijski alat od pojma ideologije, za mnoge teoretičare, a osobito za one koji provode istraživanja u okvirima kritičke analize diskursa, razlika između ideologije i diskursa nije toliko oštra, pa oni koriste oba termina koji mogu biti u različitim odnosima jedan prema drugome. Jedan od glavnih teoretičara, Fairclough (2003) barata pojmom diskursa s najmanje tri različita značenja, dok ujedno koristi i pojam ideologije pri analizi ,jezika novog kapitalizma“ koji se razvija paralelno s procesima globalizacije koji u sebi sadrže imperativ globalnog širenja neoliberalnih politika. Faircough (2003) se, u skladu s navedenim znanstvenim interesima, priklanja kritičkom ili marksističkom poimanju ideologija koje definira kao „reprezentacije aspekata svijeta za koje se može pokazati da doprinose utemeljenju, održavanju i promjeni društvenih odnosa moći, dominacije i eksploatacije“ (Fairclough 2003: 9). Prema tome, unutar kritičke analize diskursa ideologija i diskurs nisu nespojivi, iako u Foucaultovoj teoriji diskursa, pojam ,diskurs“ zapravo zamjenjuje pojam ideologije. Tako, na primjer, Sara Mills (2004) nastoji razjasniti taj odnos ukazujući na utjecaj trendova koji su vladali tijekom 1990-ih i 2000-ih godina kada su mnogi teoretičari i istraživači izbjegavali korištenje pojma ideologije koji su zamijenili terminom diskursa kako se ne bi oslanjali na teorije koje su se temeljile na marksističkom pristupu. Iako korištenje pojma „diskursa“ i sama njegova analiza ne znači isključivanje politike iz analize, ta je veza kompliciranija od veze koja se pretpostavlja pri radu s marksističkim terminom ideologije koji implicira da pojedinci u društvu pristaju na konceptualni aparat koji nije u službi njihova interesa, već interesa vladajuće klase. Diskurs je ponudio alternativu promatranju odnosa moći kroz prizmu ideologije te se u diskurzivnoj teoriji pojedince ne shvaća kao pasivne podanike povlaštene klase koji samo participiraju u sustavu koncepata i misli koji im je suštinski interesno suprotstavljen. Diskurs također implicira jedan drugačiji pristup djelovanju aktera i političkoj aktivnosti. Mills (2004) govori kako za razliku od marksizma koji sadrži relativno koherentnu utopijsku viziju budućnosti te smatra da aktivizam ima jasan cilj djelovanja koji može biti ostvaren ili ne mora, u teoriji diskursa postoji temeljna nesigurnost $u$ 
ishode bilo kakvih djelovanja te akteri naprosto ne znaju koje su sve moguće posljedice njihove akcije.

Foucault se tijekom karijere često osvrtao na svoj odnos s marksizmom koji je bez sumnje izvršio utjecaj na njegov rad, ali se u nekoliko ključnih aspekata nije slagao s nekim premisama prisutnima u toj teorijskoj orijentaciji. Foucault po pitanju ideologije kaže:

„Korištenje pojma ideologije smatram problematičnim iz tri razloga. Prvi je taj što je on, htio to netko ili ne, uvijek u opoziciji nečega što bi se moglo nazvati istinom.

... Druga je prepreka ta što se on, ja vjerujem čak nužno, odnosi na nešto poput subjekta. Treće, ideologija je u sekundarnoj poziciji u odnosu na nešto što mora funkcionirati kao njezina infrastruktura, ili neka ekonomska ili materijalna determinanta.“(Foucault 1977: 118)

Foucault problematizira tri pretpostavke karakteristične za pojam ideologije: istinu, subjekt i ekonomske determinante diskursa (Mills 2004). Teoretičari poput primjerice Althussera bave se ideologijom pretpostavljajući da je ona neka vrsta lažne svijesti (implicirajući da postoji istinita svijest), pa je u skladu s tom pretpostavkom teoretičar koji nastoji razotkriti njezino djelovanje onaj koji razotkriva istinu. U okviru spomenute kritike podrazumijeva se da znanstvenik nije pod utjecajem ideoloških sila, to jest da je njemu dostupna istina koja nije dostupna pojedincima koji djeluju pod utjecajem lažne svijesti. Foucault, u suprotnosti s ovim stajalištem, priznaje utjecaj analiziranih ideja i praksi na samog istraživača koji je ograničen diskurzivnim okvirima svojega vremena izvan kojih ne može istupiti (Mills 2004). Navedenim stajalištem Foucault ne negira vlastitu kritičku poziciju, već priznaje njezina ograničenja koja ovise o institucionalnim ograničenjima postavljenima na to o čemu je uopće moguće govoriti. Foucault se također u svojoj teoretizaciji nastoji udaljiti od koncepcije subjekta kao jedinstvenog bića, proizašlog iz kartezijanske filozofije, što je u skladu s poststrukturalističkom krizom subjekta - Foucault je tako nastojao uspostaviti „,način istraživanja povijesnih procesa bez oslanjanja na pojam subjekta“ (Mills 2004: 30).

Nasuprot Foucaultovoj analizi, analize ideologije se oslanjaju na postojanje subjekta koji je ipak u mogućnosti opirati se ideološkim pritiscima i djelovati unatoč njima. Naposljetku, Foucault ne prihvaća marksistički ekonomski determinizam te smatra da u relacijama između ekonomskih, društvenih i diskurzivnih odnosa ne možemo postaviti jedan od navedenih kao prevladavajući nad drugima. Drugim riječima, moć nije gotovo isključivo ekonomskog karaktera kako teoretiziraju marksisti, već ima različite karakteristike. Alternativno 
marksističkom načinu razmišljanja o industrijskim odnosima i organizaciji industrijskog rada, koji je sklon jednoznačno karakterizirati strukture moći i strukture kapitalizma, hijerarhijsku organizaciju rada moguće je shvatiti kao posljedicu radne discipline, koja je onda takva i u kapitalizmu. Moguće je da je organizacija industrijskog rada podložna kompleksnijoj kombinaciji odnosa moći nego što je to utjecaj i pitanje kapitalističke ideologije (Mills 2004).

Foucaultov se pojam diskursa u tom smislu razvija u dijalogu s pojmom ideologije te uostalom, i kao reakcija na ideologiju. Međutim, valja napomenuti da se ideologija kao pojam ponekad koristi i u neutralnom smislu u kojem je uostalom i nastala u 18. stoljeću u Francuskoj. Pojam ideologije je nakon Francuske revolucije skovao Antoine Destutt de Tracy ne bi li njime označio novu znanost koja se bavi idejama. Destutt de Tracyjev pojam imao je progresivni i pozitivni predznak i predstavljao je nastojanje da se podrijetlo ideja istraži na racionalan način i bez vjerskih predrasuda. Za Destutt De Tracyja ideje nisu potjecale od boga i prirode već su nastajale osjetilnom interakcijom između čovjeka i njegove društvene okoline (Richardson 2007). Karl Marx je preuzeo Destutt de Tracyjev novonastali pojam, i poziciju o iskustvenom podrijetlu ideja, ali ga je i značajno modificirao, dodavši tezu da su ideje i uvjerenja proizvodi ekonomskih okolnosti. Kao takve, ideje mogu biti istraživane kao odraz tih istih ekonomskih okolnosti. S obzirom na to da su bogatstvo, moć i status nejednako raspodijeljeni u društvu, one skupine koji imaju najveći pristup tim dobrima nadmoćno izražavaju vlastite socijalne i političke ideje; a njihove ideje su isprepletene s njihovim nastojanjima da zadrže svoje klasne privilegije (Gee 2007, Richardson 2007). Drugim riječima, Marx je smatrao da elite u društvu vjeruju ono što vjeruju jer im ta uvjerenja pomažu da zadrže svoj status i moć. Za Marxa je ideologija izokrenuta slika stvarnosti u koju skupine koje imaju mnogo manju moć vjeruju jednako kao i elite, iako je ta slika stvarnosti u suprotnosti s njihovim interesima. Elite aktivno nastoje promovirati vlastitu ideologiju, i to najčešće uspješno i čine preko organizacija $i$ institucija u društvu koje potiču uvjerenja i ponašanja koja rezultiraju održavanjem postojećih odnosa moći u društvu (Gee 2007). Marksisti su razvili mnoštvo teorija inspiriranih opisanim pogledom na ideologiju, koje su se ponekad međusobno značajno razlikovale.

U kritičkoj je analizi diskursa prihvaćen pojam ideologije, ali je on u svjetlu prigovora kritičara donekle izmijenjen. Na primjer, Richardson (2007) kritizira interpretacije Marxa koje sugeriraju da je djelovanje ideologije jednosmjerno u smislu da ekonomski odnosi proizvode lažna uvjerenja koja se suprotstavljaju interesima ljudi. On, kao i Gee (2007), smatra da te interpretacije ne uzimaju u obzir da ideologija sudjeluje i u stvaranju zbilje, a ne samo u njezinu odražavanju te da se kod ideologije ne radi o lažnim uvjerenjima, već o površnom i 
zavaravajućem prikazivanju istine. Mnogi su Marxom inspirirani teoretičari, osim ekonomskih, naglasili potrebu za proučavanjem drugih nejednakosti u društvu za koje bismo mogli reći da su učvršćivane ideologijom, kao što su na primjer rodne ili etničke nejednakosti. Uza sve kritike koje se mogu uputiti Marxovoj koncepciji ideologije, Gee (2007) ističe kako njegove teze još uvijek imaju značajnu rezonancu u suvremenim teorijama. Thomson primjerice definira ideologiju kao „značenje u službi moći“, a za Jonesa ideologija „nije bilo kakav sustav ideja ili vjerovanja već načini razmišljanja u kojima su prolazni povijesni eksploatacijski oblici društvene organizacije prihvaćeni kao vječni, prirodni, neizbježni ili 'racionalni'“ (Richardson 2007).

Na kritičku su analizu diskursa, a posebice na Normana Fairclougha i znanstvenike koji su kasnije temeljili svoja istraživanja na njegovim radovima, snažan su utjecaj, osim Foucaulta, izvršili i Louis Althusser, Michel Pecheux i Antonio Gramsci. Ti su marksistički autori nastojali dati odgovor upravo na pitanje kako dolazi do toga da ideologija prikriva eksploataciju te na taj način reproducira društvene nejednakosti. Althusser (Richardson 2007) je tako pokušao pokazati na koji se način društveni odnosi srednje klase reproduciraju putem ideologije koja može oblikovati i djelovati kao produžetak želja i uvjerenja pojedinaca, dok je Pecheux, nadovezujući se na Althussera, naglasio da „državni ideološki aparati“ nisu izraz dominacije ideologije vladajuće klase, već poprište na kojem se ta dominacija ostvaruje i pomoću kojega vladajuća klasa potvrđuje vlastitu moć. Richardson (2007) pojašnjava da prethodne tvrdnje pretpostavljaju da su ideološke formacije poput, na primjer, tiska, same po sebi poprišta klasne borbe, čiji rezultat utječe na ideološke uvjete preobrazbe proizvodnih odnosa. Gramscijeva teorija o hegemoniji važan je doprinos marksističkoj misli o ideologiji, a osobito s njime povezano razlikovanje između pojmova prisile i pristanka (Richardson 2007). Hegemonija se može definirati kao ,proces u kojem vladajuća klasa uvjeri sve ostale klase da prihvate njezinu vlast i vlastitu podređenost“" (Richardson 2007: 35). U hegemoniji podređeni prihvaćaju vlast bez upotrebe prisile, to jest, u uspješnom hegemonističkom poretku vladajuća klasa širi svoje vrijednosti uz minimalnu upotrebu sile jer podređeni prihvaćaju legitimnost onih koji vladaju. Vladajuće klase, ili elite, pridobivaju poslušnost klasa kojima dominiraju na tri različita načina. Vladajućima pripomaže u dobivanju legitimnosti, prvenstveno, uzimanje u obzir interesa radničke klase. Drugi aspekt legitimacije njihove vladavine jest trud koji se ulaže s njihove strane ne bi li se javno oglašavali njihovi ustupci radničkoj klasi. Iako se navedena činjenica o popuštanju interesima radničke klase ne može poreći, Richardson (2007) naglašava da prema Gramsciju ti kompromisi ne ugrožavaju esencijalnu nejednakost u kapitalizmu koja se temelji 
na ekonomskoj privilegiranosti vladajućih klasa. Hegemonija se također održava na način da vladajuće klase prenose svoje ideje i vrijednosti u javnost, čime podučavaju široku publiku o opravdanosti njihove vlasti.

Dakle, Norman Fairclough (1995) ideologiju definira kao „značenje u službi moći“ te pod ideologijom shvaća određene konstrukcije značenja koje utječu i doprinose stvaranju, održavanju i promjeni odnosa moći u društvu. Faircloughovo se shvaćanje ideologije napaja iz teorijskih istraživanja Althussera i Gramscija, kada se usredotočuje na ideologiju kao skup implicitnih teorijskih premisa na kojima se temelji 'nesvjesno djelovanje', dok je ideologija prema Gramsciju „koncepcija svijeta koja se implicitno prikazuje u umjetnosti, ekonomskoj aktivnosti i manifestacijama individualnog i kolektivnog života“ (Gramsci 1971: 328, prema Fairclough 1995: 76). Gramsci smatra da se subjekti strukturiraju kroz različite ideologije prisutne u njihovim praksama, stapajući se u jednu kompaktnu mješavinu, dok je ono što je prihvaćeno kao normalno i zdravorazumsko zapravo rezultat prošlih ideoloških srazova te je uvijek podložno promjenama kao rezultatu trenutnih ideoloških sukoba (Fairclough 1995). Ne bi li uspostavio konceptualnu povezanost između ideologije i jezika, Fairclough (1995) se oslanja na Althusserov pogled na ideologiju, nadopunjavajući ga Pecheuxovom fuzijom Althusserova poimanja ideologije s teorijom diskursa i metodom analize diskursa.

\subsection{Ogranci kritičke analize diskursa}

\subsubsection{Diskurzivno-historijski pristup kritičkoj analizi diskursa}

Diskurzivno-historijski pristup Bečke lingvističke škole jedan je od relevantnih pristupa koji pripada skupini konstitutivnih istraživačkih programa kritičke analize diskursa. Pristup je dobio svoje konture kroz istraživanja Ruth Wodak i njezinih suradnika među kojima su i Martin Reisigl, Florian Menz, Helmut Gruber, Gilber Weiss, Peter Muntigl i Rudolf de Cillia. Diskurzivno-historijski pristup se po svojoj socio-filozofskoj tradiciji smješta uz bok kritičke teorije jer mu je osnovni cilj razotkriti utjecaj moći i ideologije u jezičnom aspektu društvenih problema te zauzeti se za diskriminirane i marginalizirane društvene skupine pri čemu navedeni pristup sadržava i jednu utopijsku viziju egalitarnog društva uz određene preporuke kako se približiti idealu društva sa što pravednijom raspodjelom moći među društvenim akterima. Diskurzivno-historijski pristup se od ostalih istraživačkih programa u kritičko-diskurzivnoj maniri razlikuje po jedinstvenom skupu karakteristika: a) etnografsko istraživanje, b) analiza korpusa podataka koji se odnose na dulji vremenski period, c) korištenje raznovrsnih istraživačkih metoda ne bi li se istražio odabrani društveni problem, d) interdisciplinarnost, e) 
kritička analiza usmjerena na rasvjetljavanje nekog društvenog problema (Muntigl, Weiss i Wodak 2000: 3). Na primjer, u okviru diskurzivno-historijskog pristupa istraživanje organizacijskog diskursa Europske unije bi sadržavalo svih pet navedenih karakteristika. Etnografsko bi istraživanje podrazumijevalo ulazak u same organizacije pri čemu bi se nastojalo doći do nekog općeg razumijevanja o tome kako sama organizacija djeluje i koje su njezine prakse, prije nego što se započne istraživanje nekog posebnog dijela, to jest aspekta te organizacije. Istraživanje bi se također usredotočilo na djelovanje organizacijskih praksi tijekom određenog, duljeg ili kraćeg vremenskog perioda, pa bi se na primjer istraživalo na koji način službenici i dužnosnici u organizaciji donose smjernice i preporuke za javne politike, pri čemu je važno, kao prvo, istražiti korake koji dovode do neke politike, to jest sam proces te kao drugo, samu politiku, odnosno ishod procesa (Muntigl, Weiss i Wodak 2000: 3). U diskurzivnohistorijskom se pristupu također koristi nekoliko istraživačkih metoda kako bi problem bio sagledan iz različitih perspektiva, a ta se oznaka može usporediti sa Cicourelovim principom triangulacije koji u slučaju diskurzivno-historijske analize diskursa podrazumijeva korištenje različitih metoda ne bi li se što bolje opisala istraživana društvena pojava (Muntigl, Weiss i Wodak 2000). Spomenuta se interdisciplinarnost odnosi na istovremeno oslanjanje na lingvističke teorije i teorije o društvu. I na koncu, istraživanja u diskurzivno-historijskom pristupu su također kritički usmjerena jer su koncipirana kao angažman oko nekog važnog, aktualnog društvenog problema.

Ruth Wodak opisuje diskurzivno-historijski pristup kao interdisciplinarnu istraživačku tradiciju koja kombinira temeljne teorijske smjernice kritičke analize diskursa - kao teorijski temelj diskurzivno-historijskog pristupa, s empirijskim istraživanjima koja podrazumijevaju analizu velikih korpusa tekstova i elemente etnografskog istraživanja (Kendall 2007). Diskurzivno-historijski pristup se koncentrira na analizu tekstova pri čemu se oslanja na elemente argumentacijske teorije i retorike, međutim za same je teorijske sklopove kao podloge za tekstualne analize karakterističan već spomenuti eklekticizam, pa oni variraju između istraživača i predmeta istraživanja. Diskurzivno-historijski pristup, u skladu s propozicijama kritičke analize diskursa, shvaća pisani i govorni jezik kao društvenu praksu te ,pretpostavlja dijalektički odnos između takozvanih diskurzivnih praksi i određenih oblika djelovanja (uključujući situacije, institucionalne okvire i društvene strukture) u kojima su oni ukorijenjeni: s jedne strane situacijsko, institucionalno i društveno okruženje koje oblikuje i utječe na diskurse, a s druge strane diskursi utječu na diskurzivne i nediskurzivne društvene i političke procese i djelovanja“ (Reisigl i Wodak 2001: 35-36). Bečki kritički analitičari nastoje u okviru 
diskurzivno-historijskog pravca svojim istraživanjima doprinijeti poboljšanju komunikacije unutar javnih institucija kao što su škole, bolnice ili sudnice (Reisigl i Wodak, 2001). Pomoću spoznaja dobivenih istraživanjem, znanstvenici ovog pristupa ocrtavaju smjernice za djelovanje ne bi li uklonili barijere u komunikaciji koje su ustanovljene tijekom istraživanja. U svojoj knjizi Discourse and Discrimination (2001), Wodak i Reisigl ocrtavaju konture diskurzivnohistorijskog pristupa i navode glavne predmete istraživanja tog pravca, pa se tako jedno veće istraživanje bavilo fenomenom antisemitizma $u$ Austriji, tj. opisivanjem antisemitskog stereotipa prisutnog u austrijskom javnom diskursu. Nadalje, istraživači su se također bavili elementima diskriminacije usmjerene protiv rumunjskih imigranata i azilanata u komunikaciji austrijskih masovnih medija te proučavanjem diskursa o austrijskom nacionalnom identitetu i naciji. U tradiciji diskurzivno-historijskog pristupa također je značajno istraživanje politika Europske Unije na tržištu rada koje je prezentirano u knjizi European Union Discourses on Un/employment: an interdisciplinary approach to employment policy-making and organizational change (2000). Navedeno se istraživanje temelji na premisi da je važno istražiti procese koji dovode do donošenja odluka o javnim politikama te njihovoj implementaciji kako bi se razumjelo djelovanje političke zajednice. „Stoga je istraživanje fokusirano na to na koji su način javne politike diskurzivno proizvedene i transformirane ili rekontekstualizirane $u$ različitim fazama donošenja javnih politika te koje je razlike u tekstualnom aspektu politika tijekom istraživanja moguće otkriti“ (Muntigl 2000: 2). Muntigl (2000) nadalje kaže kako je cilj diskurzivno-historijskog pristupa u istraživanju politika Europske Unije, ustanoviti koje se ideologije konstruiraju i zrcale u procesu donošenja javnih politika te koje se od njih u tom razdoblju bivaju istaknute, a koje se na neki način guraju u pozadinu. Istraživanje se sastoji od etnografske faze kroz koju se proučavaju institucionalne prakse Europske unije i njihov tekstualni, odnosno diskurzivni aspekt te na koji način te diskurzivne prakse utječu na formiranje javnih politika zapošljavanja. Intertekstualnost se nalazi u međuprostoru između procesa razvoja i pregovaranja o obliku politika i rezultata tog procesa pregovora, a analizira se kroz proučavanje diskurzivne prakse rekontekstualizacije. U rekontekstualizaciji se traže mjesta gdje sporna ideološki obojena pitanja postaju zatomljena u svrhu postizanja konsenzusa. „To jest, rekontekstualizacijske prakse mogu učvrstiti moguće suprotstavljene teme ili mogu, putem apstrakcija, generalizacija, itd., upakirati ideologiju na način da zamagle njezine oprečne teme“" (Muntigl 2000: 23). U spomenutom se istraživanju koristi diskurzivno-historijski pristup ne bi li se analizirale neoliberalne ili kejnzijanske ideološke teme, ili neke druge, koje su tijesno povezane s politikama zapošljavanja te na koji se način u tekstovima diskurzivno konstruiraju pojmovi zaposlenosti i nezaposlenosti. U diskurzivnu analizu ulazi proučavanje tekstualne 
dimenzije institucionalnih praksi Europske Unije, pri čemu prikupljaju razne vrste zapisa o komunikaciji između službenika u Europskoj Uniji, pa je u analizu uključen i etnografski moment. Pristup također prilazi historijski samoj temi pa nudi i uvid u povijesni razvoj i promjene u donošenje javnih politika o zapošljavanju u Europskoj Uniji te multidisciplinarne pristupe analizi različitih faza $\mathrm{u}$ donošenju spomenutih javnih politika. Pri samoj analizi komunikacija unutar institucija Europske unije, Ruth Wodak (2000) kombinira Hallidayevu sistematsko-funkcionalnu analizu, ne bi li proučila strukturu tekstova u terminima tema-rema, sa sistemskom teorijom Niklasa Luhmanna pomoću koje otkriva „premise odlučivanja“ Europskog parlamenta o politikama. U još jednoj analizi povezanoj s istim istraživanjem, Peter Muntigl (2000) analizira debate u Europskom parlamentu o rezolucijama koje se tiču politika zapošljavanja i regulacije radnoga vremena, pri čemu koristi kombinaciju pristupa sistemskofunkcionalne gramatike diskurzivnim praksama i Burkeovu analizu retorike fokusirajući se na ideološke dileme u vezi organizacije radnog vremena.

Ono što je važno napomenuti pri opisu diskurzivno-historijskog pristupa jest to da on ne nudi jedan osnovni jedinstveni model kritičke analize diskursa, kao što to pokušavaju osigurati Theo van Leeuwen (2008) ili Norman Fairclough (2003). U radovima jasno dolazi do izražaja eklekticizam metoda i teorijskih koncepata, prilagođavanje odabira metoda samome predmetu istraživanja uz određenu dozu eksperimentiranja s različitim kombinacijama analiza kao što su funkcionalna gramatika, ili argumentacijska analiza, na primjer (Kendall 2007). Sloboda spomenutog eklekticizma uokvirena je već navedenim osnovnim principima diskurzivno-historijskog pristupa koji podrazumijeva etnografsko istraživanje, kritičku orijentaciju, usmjerenost na društveni problem te interdisciplinarni pristup $\mathrm{u}$ analizi korpusa tekstova.

\subsubsection{Van Dijkova kritička analiza diskursa - sociokognitivni pristup}

Teun van Dijk je dao značajan doprinos teorijskom formiranju istraživačkog programa kritičke analize diskursa. Kada raspravlja o povijesnoj pozadini samog pristupa, van Dijk navodi niz filozofa i istraživača koji su izvršili utjecaj na kritičku perspektivu proučavanja jezika, čija tradicija seže sve do Aristotela, prosvjetitelja, zatim Marxa, Frankfurtske škole, neomarksista poput Gramscija, Stuarta Halla, Althussera, Pecheuxa te Foucaulta (van Dijk 1993). Za van Dijka (2001) kritička analiza diskursa nije niti teorija ni metoda, već jedna kritička perspektiva koja se može, kao diskurzivna analiza, ili niz tehničkih postupaka analize tekstova, sparivati s bilo kojom disciplinom ili pristupom u društvenim i humanističkim 
znanostima. Ono što je razlikuje od ostalih oblika analize diskursa jest usredotočenost na društvene probleme te propitivanje uloge diskursa u reprodukciji dominacije te posljedično propitivanje uloge diskursa u održavanju odnosa nejednakosti u društvu. Van Dijk (2001) smatra da društvene elite imaju moć i mogućnosti pristupa resursima proizvodnje diskursa koje su nedostupne ostatku društva. Preko svog povlaštenog pristupa koji omogućuje institucionalizacija i organizacija dominacije u društvu, elite su u mogućnosti kontrolirati koje će ideje postati „naturalizirane“, to jest, koji će odnosi u društvu diskurzivnim praksama biti učinjeni prirodnima i neizbježnima u umovima ostatka društva. U van Dijkovoj (1993) varijanti kritičke analize diskursa, njezin je osnovni cilj proučavanje i razotkrivanje diskurzivnih izvora moći i dominacije te opisivanja na koje se načine ta moć i dominacija odražavaju na nejednakost u društvu ovisno o specifičnom društveno-povijesnom i političkom kontekstu. „Iako postoje mnogi smjerovi u proučavanju i kritici društvene nejednakosti, način na koji mi pristupamo tim pitanjima i dimenzijama jest fokusirajući se na ulogu diskursa u (re)produkciji i osporavanju dominacije“ (van Dijk 1993: 283). Pod dominacijom se misli na djelovanje koje omogućuje koncentraciju moći pri društvenim, političkim i ekonomskim elitama, zatim institucijama ili pojedinim društvenim grupama. Dominacija rezultira društvenom nejednakošću; konkretno u obliku rasne, rodne, etničke, klasne, kulturne ili političke nejednakosti. Elite su u mogućnosti kontrolirati proizvodnju diskursa kao što su javni diskurs, politički diskurs, medijski diskurs, diskurs znanosti, organizacijski diskurs i slično. Van Dijkov (2001) se pristup odnosu diskursa i moći vodi jednostavnom logikom da su ljudska djela oblikovana ljudskim vrijednostima, uvjerenjima i stavovima, odnosno da se utjecajem na razmišljanja ljudi, na to o čemu oni razmišljaju i kada to čine, mogu oblikovati njihova djelovanja, odnosno njihove prakse. Pojednostavljeno rečeno, one društvene skupine koje mogu kontrolirati utjecajne i dominantne diskurse, mogu kontrolirati umove i djelovanja drugih članova društva.

Ne bi li dodatno pojasnio moć diskurzivnog djelovanja, van Dijk (2001: 355) daje odgovor na dva osnovna pitanja važna za istraživanja kritičke analize diskursa, a to su: a) na koji način elite kontroliraju javni diskurs? te b) na koji način takav diskurs kontrolira misli i djelovanje ostalih, manje moćnih članova društva i skupina, i koje su posljedice te kontrole? Kada odgovara na prvo pitanje, van Dijk kaže da većina ljudi ima određeni udio u kontroli svog svakodnevnog govora kroz koji ostvaruje komunikaciju s bližnjima. Međutim obični su ljudi najčešće samo primatelji poruka i govora svojih „,nadređenih“ kao što su primjerice, učitelji, šefovi, suci, policajci ili pak novinari. Neki od navedenih članova društvenih skupina i institucija imaju povlašten pristup određenim pojavnostima javnog diskursa, a to su na primjer, 
znanstvenici, političari, novinari, odvjetnici, i tako dalje. Pristup proizvodnji diskursa i njegova kontrola određeni su kontekstom i strukturama teksta ili govora. „Kontekst je definiran kao mentalno reprezentirana struktura onih osobina društvene situacije koje su važne za proizvodnju i razumijevanje diskursa“" (van Dijk 2001: 356). Kontekst se sastoji od sljedećih kategorija: cjelokupna definicija situacije, mjesto i vrijeme, odvijanje aktivnosti, sudionika u svojim društvenim i komunikacijskim ulogama te mentalne reprezentacije poput ciljeva, znanja, mišljenja i ideologija. Kontrola se konteksta svodi na kontrolu jedne ili više od ovih kategorija. S druge strane, kontrola strukture teksta ili govora odnosi se, primjerice, na odabir žanrova u komunikaciji, također, kada govorimo o osobinama tekstova, moćniji (su)govornici često kontroliraju temu u komunikaciji. Što se pak tiče samog utjecaja, pa čak i kontrole mišljenja ljudi od društvenih elita, ona isto tako uvelike ovisi o kontekstualnim uvjetima komunikacije; nekad su sudionici u komunikaciji u situaciji da budu isključivo pasivni primatelji naredbi ili informacija. Na primjer, kada govorimo o javnom medijskom diskursu, možemo zamisliti situaciju u kojoj mediji ne nude dovoljno informacija za alternativna tumačenja neke situacije ili događaja. Postoje i tekstualni uvjeti koji utječu na percepciju čitatelja, pa je zato dio zadatka van Dijkove varijante kritičke analize diskursa otkriti kako diskurzivne strukture utječu na mentalne reprezentacije. Na globalnoj razini utjecaj se vrši pomoću tema, jer teme utječu na to što ljudi vide kao najvažnije u nekom tekstu. Na lokalnoj razini teksta utjecaj se vrši pomoću pretpostavki, koje odražavaju neko mnijenje koje je na neki način skriveno, odnosno nije eksplicitno izrečeno, nego se pretpostavlja u tekstu. Time se „poželjne“ tvrdnje ili argumenti lakše prihvaćaju jer se oslanjaju na premise koje su u tekstu implicitno ili prešutno prihvaćene.

Diskurs se može povezati s moći na različite načine u samom procesu reprodukcije nejednakosti, a spomenuto povezivanje može biti u vidu otvorene podrške nekog oblika nejednakosti, zatim kroz reprezentaciju, legitimaciju, poricanje, opravdavanje ili prikrivanje dominacije, i tako dalje (van Dijk 1993). Van Dijk (1993) opisuje kako je moguće proučavati odnose između diskurzivnih struktura i struktura moći na izravan način, pri čemu se misli na proučavanje struktura kao što su imperativ ili izdavanje naredbi čime se jasno izražava pozicija moći; zatim stila, retorike ili značenja u tekstovima kojima se prikriva pozicija moći. Međutim, često baš (zlo)upotreba moći nije toliko očita u rečeničnim strukturama tekstova, kao kada se radi o jednostavnim odnosima poput policajca i građanina, već je riječ o nelegitimnoj upotrebi moći koja se odnosi na makro razinu kao što su institucije ili društvene grupe. Tu se pojavljuje problem odnosa mikro i makro razine, ali i problem odnosa između diskursa, društva i društvene 
spoznaje. Van Dijk se zalaže za to da se u diskurzivnu analizu uključe i istraživanja društvenih reprezentacija kako ih zamišljaju društveni akteri, tj. da je „društvena spoznaja nužno teorijsko (i empirijsko) 'sučelje', ako ne i 'karika koja nedostaje', između diskursa i dominacije“ (van Dijk 1993: 251). Društvena je spoznaja reprezentacija odnosa u društvu koju dijele njegovi članovi i ona se nalazi u temeljima organizacije društva kao cjeline, a s obzirom na to da je kritička analiza diskursa usredotočena na društvene probleme te moć, dominaciju i društvenu nejednakost, ona proučava institucije i društvene grupe, pa se valja usredotočiti na ideologije, norme, vrijednosti, znanja i stavove koje dijele društveni kolektiviteti (van Dijk 2001). Van Dijk (2001) se, kako sam kaže, bavio pitanjima rasizma i ideologije pri čemu se usredotočio na društveno-kognitivni aspekt analize diskursa, pokazujući da su ti istraživani fenomeni ujedno i društveni i kognitivni. Osim proučavanja odnosa između društva i diskursa, van Dijk tu uključuje jedan posredujući moment spoznaje ili kognicije pri čemu je zaokupljen proučavanjem mentalnih reprezentacija korisnika jezika kojima se oni služe ne bi li tumačili i proizvodili diskurs i komunicirali te proučavanjem znanja i ideologija zajedničkih društvenim grupama. „U isto vrijeme, takav pristup proučava načine na koje su takvi spoznajni fenomeni povezani sa strukturama diskursa, verbalnim interakcijama, komunikacijskim događajima i situacijama, kao i socijetalnim strukturama, kao što su dominacija i društvena nejednakost (...)“ (van Dijk 2009: 64). Sociokognitivni je pristup prikazao pomoću konceptualnog trokuta diskurs-spoznaja-društvo, pri čemu su za njega tipični kognitivni pojmovi na primjer: um, misao, percepcija, pamćenje, sjećanje, semantički mentalni modeli (subjektivne reprezentacije događaja i situacija), pragmatički kontekstualni modeli (subjektivne reprezentacije o svojstvima komunikativnih situacija kojima se prilagođava sam diskurs), znanje i organizacija znanja, ideologija kao zajednička uvjerenja pojedinih društvenih grupa (neoliberalizam, feminizam, pacifizam, itd.), stavovi kao ideološki zasnovana mnijenja o određenim društvenim pitanjima (razvod, abortus, eutanazija, itd.) i slično (van Dijk 2009). Kombinacija kognitivne i socijalne dimenzije trokuta u neformalnom smislu tvori relevantni kontekst diskursa, pri čemu valja naglasiti da je taj trokut samo jedna analitička metafora koja predstavlja dimenzije analize diskursa. Kognitivna i društvena dimenzija kao kontekst neka su vrsta subjektivne mentalne reprezentacije, to jest ona je mentalna 'definicija situacije' „koja kontrolira adekvatnu adaptaciju proizvodnje diskursa i razumijevanja njihovu društvenom okruženju“ (van Dijk 2009: 66).

Van Dijk (1988) se također upustio u analizu karakteristika i strukture novinskih članaka i vijesti kao diskurzivne prakse kojima su svojstvene određene specifičnosti vezane uz žanr i organizaciju proizvodnje i recepcije novinskih članaka. Van Dijk (1988) smatra da su 
dosadašnje analize medija tiska dale značajne uvide u mikrosociologiju i makrosociologiju proizvodnje vijesti i novinskih tekstova. Ta su se istraživanja usmjeravala na analizu same prakse pisanja vijesti, njihova prikupljanja te na odgovaranje na pitanje na koji način ograničenja i mogućnosti koje su zadane u okviru institucionalizacije društvene prakse proizvodnje novinskih članaka utječu na svakodnevnu profesionalnu praksu novinara. Međutim, ono čime se tu van Dijk bavi i za što smatra da nedostaje u suvremenim analizama novina jesu lingvističke, kulturalne i ideološke analize tekstova, koje valja integrirati s već spomenutim mikrosociološkim i makrosociološkim pristupima novinskoj produkciji.

Van Dijk (1988), slično kao i Fairclough (2003), zagovara kontekstualnu analizu te smatra da se analiza diskursa novina može podijeliti na dvije komponente: na tekstualnu i kontekstualnu komponentu. Prva komponenta se sastoji od sistematičnog istraživanja različitih struktura novinskog diskursa, dok se kontekstualna komponenta, po van Dijku (1988) sastoji od analize kognitivnih i društvenih čimbenika te uvjeta i ograničenja postavljenih na stvaranje tekstualnih struktura te njihovo ekonomsko, povijesno i kulturno okruženje. Prema poviše navedenom, van Dijkova se analiza podudara s prve dvije faze u Faircloughovoj kritičkoj analizi diskursa, a to su analiza teksta i analiza diskurzivnih praksi (Fairclough 2003).

Semantička makrostruktura jedna je od specifičnosti svojstvenih diskursu novina. Pod semantičkom se makrostrukturom misli na opću temu novinskog izvještaja. Ta je makrostruktura osnova procesa novinskog izvještavanja jer određuje srž ili meritum ili najvažniju informaciju novinskog članka (van Dijk 1988). Kako kaže sam van Dijk (1988), za razliku od drugih oblika tekstova, za novinske je članke karakteristično to što je makrostruktura eksplicitno izrečena, odnosno srž, meritum, to jest najbitnija informacija novinskog članka navedena je najčešće u naslovu ili podnaslovu teksta. S obzirom na to da se informacije u novinskim člancima najčešće oslanjaju na neko prijašnje znanje čitatelja o određenoj temi, na neke stavove i mišljenja, odnosno na nešto što se pretpostavlja, neko pozadinsko znanje, često dolazi do toga da se u naslovima naziru konture neke specifične ideologije, ili naznake određene vrste pristranosti. Moguće je dakle, da opis situacije sadržan u semantičkoj makrostrukturi bude u mnogočemu drugačiji od nekih alternativnih tumačenja iste situacije. Makrostrukture su povezane s uvjetima u proizvodnji novinskih članaka te njima svojstvenim ograničenjima, pa su često ideološke naklonjenosti pojedinih uređivačkih politika izražene upravo u spomenutim, eksplicitno istaknutim semantičkim makrostrukturama ili sažecima glavne teme novinskog teksta. 
Diskurzivni ili komunikacijski događaji su u pojedinim žanrovima organizirani i strukturirani na različite načine, pa je tako konvencionalna struktura kratke priče, na primjer, organizirana u tri osnovna koraka, a to su postavljanje miljea, zaplet i rasplet. Novinski tekst kao komunikacijski događaj također ima vlastitu konvencionalnu strukturu koja se rutinski mapira na većinu novinskih članaka. Van Dijk (1988) spomenutu strukturu naziva novinskom shemom koja se sastoji od kategorija koje imaju svoje funkcije prezentiranja informacija, a one su: sažetak (naslov i uvodni odlomak), glavni događaji, pozadina (kontekst i povijest), posljedice (posljedični događaji ili aktivnosti te verbalne reakcije), komentari (evaluacija i predviđanja). Nema svaki novinski članak sve navedene kategorije, ali sažetak i glavni događaji čine obavezne komponente. Za novine je karakteristično to što se o pojedinima temama objavljuje u serijskim člancima, gdje se lanci članaka o nekom događaju oslanjaju na pozadinsko znanje čitatelja i novinara te prethodne izvještaje u novinama. Pojedinačni su tekstovi strukturirani prema principu relevantnosti, pa su podaci važniji za temu smješteni na početak teksta, a prema relevantnosti i strukturnim kategorijama novinskog članka slijede druge informacije. Van Dijk (1988) kaže kako je spomenuta struktura novinskih članaka koji slijedi princip relevantnosti povezana s proizvodnim strategijama u praksi novinarstva, strukturnim modelima koje imaju sami novinari te pretpostavljenim navikama samih čitatelja koje se odnose na čitanje novina, kao što je na primjer čitanje samo naslova ili „,prelijetanje“ tekstova. Struktura novinskih tekstova ima i svoju retoričku dimenziju jer pomoću organizacije teksta i rečenica, naslova, dodataka, naglasaka, izostavljanja te redoslijeda riječi, moguće je isticati aspekte događaja ne bi li oni izvršili veći utjecaj na same čitatelje. „Iako je ustanovljeno da diskurs novina u principu nije usmjeren na uvjeravanje /čitateljstva/, on može imati jednu uvjeravajuću dimenziju u jednom više indirektnom smislu. Čak i ako ne zagovara neku poziciju ili mišljenje, on ih u svakom slučaju pretpostavlja, zbog svoje društvene, pa stoga i ideološke ukorijenjenosti“ (van Dijk 1988: 179). Praksa je proizvodnje novina također zaokupljena nastojanjima da novine dokažu svoju vjerodostojnost i utemeljenost na istini, pa se u novinskim člancima često citiraju stručnjaci ili statistički podaci, a i brojke koje retorički pripomažu djelotvornosti novina.

Kod kritičke analize novinskih članaka važno je istražiti uvjete njihove produkcije kroz institucionalnu praksu pisanja i izdavanja novina koja je uvelike rutinizirana. Sastavljanje članaka u najvećoj mjeri podrazumijeva obradu tekstova i govora iz različitih izvora. Novinari se rijetko nađu na mjestu događaja o kojemu izvještavaju, već većinu vremena njihov posao podrazumijeva obradu kodiranih verzija događaja koje dobivaju od novinskih agencija, 
izvještaja svjedoka, drugih medija, raznih oblika dokumentacije, intervjua iz druge ruke, izjava za tisak ili tiskovnih konferencija, sažetaka sa sastanaka, sjednica i drugih oblika diskursa (van Dijk 1988). Novinari također imaju zadatak prenijeti velike količine teksta u formu relativno kratkih članaka pri čemu se koriste strategijama koje se oslanjaju na već spomenute semantičke makrostrukture.

\subsubsection{Faircloughov okvir za kritičku analizu diskursa}

Kritička analiza diskursa istraživački je program nastao kao zajednički pothvat nekolicine istraživača koji su se pretežito bavili lingvistikom i lingvističkim analizama postavljajući naglasak na međuodnose jezika i drugih društvenih fenomena. Kritička analiza diskursa heterogeni je pristup društvenim istraživanjima pri čemu pojedini istraživači uživaju značajnu slobodu u tumačenju pojmovnog aparata teorijske pozadine kritičke analize diskursa te pri odabiru konceptualnih alata lingvističke analize teksta pa napokon i pri planiranju samih istraživanja. Od već navedenih pristupa lingvista poput Teuna van Dijka ili Ruth Wodak, varijanta Normana Fairclougha uživa reputaciju metodološki najrazrađenijeg oblika kritičke analize diskursa (Jørgensen i Phillips 2002). Paralelno s razvijanjem okvira za kritičku analizu diskursa, u koju je postupno ugrađivao i ideje drugih istraživača, prvenstveno Thea van Leeuwena i Teuna van Dijka, Fairclough se bavio primjenom svoje varijante kritičke analize diskursa $\mathrm{u}$ istraživanju pretežito političkog diskursa i njegove povezanosti s diskurzivnim konstrukcijama novog kapitalizma, ili neoliberalnog diskursa. Za Fairclougha (2002, 2003) je karakteristična analiza vrlo malog broja tekstova, najčešće jednog teksta, na kojemu demonstrira upotrebu lingvističke analize teksta unutar šireg okvira kritičke analize diskursa te donosi zaključke o svojstvima pojedinih diskursa koji u tekstove, odnosno u komunikaciju, unose elemente različitih ideologija, kao i kroz kontekstualno djelovanje između tekstova i društvenih praksi preko niza oblika diskurzivnih praksi.

Fairclough je pri oblikovanju svog pristupa otpočeo od činjenice da svaki društveni fenomen ima svoju jezičnu dimenziju, pa se zato sve društvene pojave ili društveni problemi mogu istraživati kroz prizmu njihove jezične manifestacije. Faircloughova analiza zato se usredotočuje na tekst kao mjesto na kojemu valja tražiti indikatore određenih društvenih pojava, procesa ili društvenih praksi te inzistira na društvenoj utemeljenosti određenih karakteristika pojedinih tekstova, ne bi li izbjegao zamku jednostranog lingvističkog tumačenja teksta. U svojim je radovima Fairclough zadao konceptualni okvir koji smješta tekstove u okvire diskurzivnih praksi i društvenih praksi (Slika 2.1) kako bi naglasio integralnost svih triju analiza 
i njihovih međuodnosa u kritičkoj analizi diskursa. Prema Faircloughu (1992) kod istraživanja neke jezične manifestacije, nekog komunikacijskog događaja, valja uvažiti njegovu trodimenzionalnost odnosno postojanje tri različite integralne komponente koje je moguće istraživati u kritičkoj analizi diskursa. Faircloughov model (Slika 2.1) prikaz je odnosa između tri aspekta diskurzivnog analitičkog konstrukta, a to su tekst, diskurzivna praksa i društvena praksa. Valja ukazati na to da je opisana distinkcija između tekstova, diskurzivnih praksi i društvenih praksi zapravo podjela analitičkog tipa te da su granice između spomenutih dijelova analize artificijelne, a dijelovi se u konkretnim pojavljivanjima komunikacijskih događaja pretapaju jedan s drugim. Svaki je tekst, ili govor, jezična manifestacija ili artikulacija neke društvene ili diskurzivne prakse, pa zato možemo govoriti samo o razlikama u smislu podjele na apstraktno i konkretno, ili opće i specifično. Kao paralelu opisanoj analitičkoj trodiobi, Fairclough (2003) govori o trodiobi društvenih fenomena koji se mogu s obzirom na razinu općenitosti promatrati kao društvene strukture, društvene prakse i društveni događaji. Ako navedenoj podjeli društvenih fenomena pridružimo njihove pandane iz društvene sfere komunikacije, semioze i proizvodnje značenja, onda možemo reći da je jezik jedna od apstraktnih društvenih struktura koje određuju ono o čemu je moguće govoriti, ali i ono što nije moguće izreći zbog ograničenja koje društvene strukture postavljaju na diskurzivne prakse, pa tako i na samu komunikaciju između društvenih aktera. Ako su tekstovi elementi društvenih događaja, oni nisu samo proizvod potencijala koji je definiran putem jezika, već postoje neki posredujući organizacijski elementi primarno jezičnoga, lingvističkoga karaktera koji čine dio društvenih praksi, a nazivaju se poredcima diskursa; to su sklopovi društvenih praksi u njihovu lingvističkom aspektu, a čine ih diskursi, žanrovi i stilovi (Fairclough 2003). „Ovi elementi biraju određene mogućnosti definirane jezikom i isključuju druge - oni kontroliraju lingvističku varijabilnost za određena područja društvenog života. Zato poretke diskursa možemo shvatiti kao društvenu organizaciju i kontrolu lingvističke varijacije“ (Fairclough 2003: 24). Iz navedenoga proizlazi da žanrovi, diskursi i stilovi nisu samo lingvističke kategorije već one premošćuju podjelu između jezika i ne-jezika te diskurzivnoga i ne-diskurzivnoga. Jezik kao društvena praksa Faircloughova je definicija diskursa ili diskurzivnih praksi koje se manifestiraju u obliku tekstova. Fairclough (2003) je svoju varijantu kritičke analize diskursa opisao kao istraživanje kontinuiteta i promjena na razini apstraktnih i relativno trajnih jezičnih struktura (koje su ujedno i jedna vrsta društvenih struktura), ali i promjena i stanja u pojedinim tekstovima. Fairclough je tako ocrtao načine na koje se diskurzivne prakse artikuliraju u pojedinačnim tekstovima i to uz pomoć analitičke podjele diskurzivnih praksi na akcije ili 
djelovanja, identifikacije i reprezentacije, koje označavaju načine djelovanja jezika, to jest njegove praktične funkcije prenošenja nekog od oblika značenja.

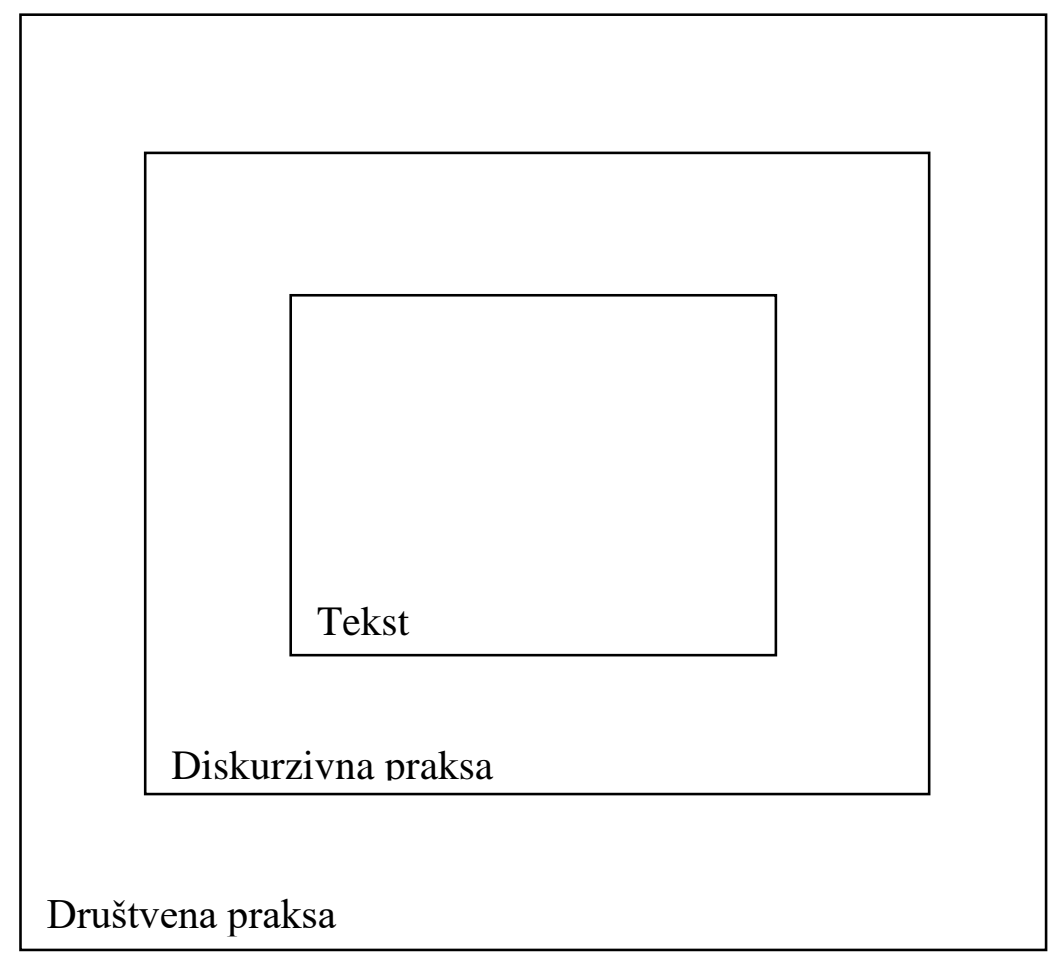

Slika 2.1 Faircloughov konceptualni okvir kritičke analize diskursa (1996/1989)

Treba naglasiti da Fairclough također nastoji izbjeći jednostranu percepciju odnosa između jezika i ostalih društvenih praksi, pa je u samom temelju njegova analitičkog okvira pretpostavka o dijalektičkom odnosu između jezika i društvenih praksi. Društveni procesi konstituiraju jezik, koji također povratno konstituira društvene procese i pojave. Na razini tekstova možemo pratiti međuutjecaj jezika i drugih društvenih praksi jer su tekstovi prema Faircloughu (2006/1992) elementi društvenih događaja koji mogu imati kauzalne učinke. Naime, najjednostavnije rečeno, tekstovi mogu utjecati na društvene promjene na način da mijenjaju našu percepciju i znanje o društvu te utječu na naše stavove, vrijednosti i uvjerenja. Fairclough nadalje pojašnjava da su upravo zbog potencijala utjecaja tekstova na društvo i društvene promjene, oni također i svojevrsna arena u kojoj se odvijaju ideološke borbe preko kojih određeni društveni akteri nastoje učvrstiti svoj povlašteni položaj ili barem poljuljati poziciju moći suprotstavljene strane. Spomenutim se dijalektičkim odnosom međusobnog 
konstituiranja društvenih procesa $\mathrm{i}$ njihovih tekstualnih artikulacija bavi kritička analiza diskursa $\mathrm{i}$ to kroz proučavanje diskurzivnih praksi preko kojih se ostvaruje spomenuti dijalektički odnos. Diskurzivne prakse dakle predstavljaju jedan posredujući analitički moment koji omogućuje pojašnjavanje načina na koji su društvene prakse pod utjecajem određenih sklopova ideja ili ideologija koje se pojavljuju u pojedinačnim tekstovima, ali i načina na koji društveni čimbenici, odnosno društvene prakse uvjetuju ili utječu na oblikovanje samih tekstova. Diskurzivne su prakse ujedno i društvene prakse jer obavljaju određene društvene funkcije čime utječu na društvo i društvene prakse, ali druge društvene prakse poput primjerice ekonomije ili politike također vrše povratni utjecaj i zadiru u sferu diskursa jer te prakse imaju i svoju jezičnu, to jest diskurzivnu dimenziju. Jedini način na koji možemo proučavati diskurzivne prakse jest preko pojedinačnih komunikacijskih događaja ili tekstova, pri čemu je za Fairclougha tekst ne samo pisani komad jezika, već to može biti i neka usmena jezična interakcija, ili na primjer televizijska emisija, pa su onda u tekst uključeni i neki vizualni prikazi kao elementi diskursa. Fairclough (1996/1989) smatra da je u tom momentu ključno razlikovati tekst od diskursa. Tekst je samo jedan proizvod koji nastaje u procesu interakcije diskurzivnih praksi sa drugim društvenim praksama, dok je diskurs upravo cijeli taj spomenuti proces interakcije jezične pojavnosti s ostalim društvenim pojavnostima.

Osnovni predmet Faircloughove (2006/1992) analize je međusobni utjecaj jezika i društvenih praksi, a taj se međusobni utjecaj može istražiti i opisati analitičkim kategorijama diskurzivnih praksi. Diskurzivne su prakse izvedene iz funkcija jezika koje je opisao osnivač sistemske funkcionalne lingvistike Michael Alexander Kirkwood Halliday. On je naime naveo tri osnovne funkcije jezika, a to su: informacijska, ideacijska i interpersonalna. Diskurzivne su prakse društvene prakse koje imaju funkciju samog društvenog djelovanja te društvene reprezentacije i konstituiranja identiteta (Tablica 2.1). Diskurzivne prakse predstavljaju međurazinu koja spaja tekstualno s društvenim, pa tako analiza društvenih praksi predstavlja analizu diskursa u užem smislu. Za Fairclougha je analiza diskursa „osciliranje između usredotočenosti na specifične tekstove i usredotočenosti na ono što ja nazivam 'poretkom diskursa', relativno stabilne društvene strukturiranosti jezika koja je sama po sebi jedan element relativno trajnog strukturiranja i povezivanja društvenih praksi. Kritička se analiza diskursa bavi kontinuitetom i promjenama na ovom apstraktnijem, strukturalnom nivou, kao i time što se događa u pojedinim tekstovima“" (Fairclough 2003: 3). Iz navedenoga citata proizlaze dvije razine kritičke analize diskursa, a to je tekstualna analiza koja obuhvaća leksičku, gramatičku i sintaktičku analizu, dok diskurzivna analiza povezuje nalaze tekstualne analize s diskurzivnim 
praksama koje imaju određene značenjske funkcije. S obzirom na to da je cilj same analize diskursa povezati tekstualno $\mathrm{s}$ društvenim praksama i to preko diskurzivnih praksi koje predstavljaju posredujući moment između tekstualnog i društvenoga, i preko kojih se odvija spomenuta dijalektička međuuvjetovanost, analiza diskurzivnih praksi je povezivanje ishoda tekstualne analize s potencijalnim učincima koje tekstovi imaju na društvene prakse te povezivanje potencijalnih učinaka društvenih praksi na tekstove koje oni ostvaruju putem poretka diskursa. Valja pojasniti da iako su tekstualna analiza i analiza diskurzivnih praksi u Faircloughovom (2003) analitičkom okviru omeđene, odnosno razdvojene, u praktičnom smislu analiza teksta i analiza diskurzivnih praksi zapravo se odvijaju istovremeno kada se radi o analizi interdiskurzivnosti ili poretka diskursa.

\begin{tabular}{|c|c|c|}
\hline \multicolumn{3}{|c|}{ Tablica 2.1 Tipovi značenja prema Normanu Faircloughu } \\
\hline Tip značenja & Korespondirajući aspekt diskursa & $\begin{array}{c}\text { Korespondirajuća funkcija prema } \\
\text { sistemskoj funkcionalnoj gramatici }\end{array}$ \\
\hline Akcija & Žanr & Komunikacijska \\
\hline Reprezentacija & Diskurs & Ideacijska \\
\hline Identifikacija & Stil & Interpersonalna \\
\hline
\end{tabular}

Kada na pojedinačnom komunikacijskom događaju, koji je ujedno i društveni događaj, a za potrebe analize taj komunikacijski događaj nazivamo tekstom, analiziramo kategoriju žanra moguće je obratiti pozornost na nekoliko točaka analize koje opisuje Norman Fairclough (2003).

\section{Poredak diskursa}

Za konkretniju upotrebu termina diskursa, Fairclough (1992) definira diskurs kao uporabu jezika unutar određenog područja društvene djelatnosti, pa tako možemo govoriti o političkom ili znanstvenom diskursu. Norman Fairclough (2003) se u svojoj definiciji diskursa oslanja na temeljne ideje Michela Foucaulta koji pod analizom diskursa podrazumijeva, kao što je već spomenuto, analizu sfere „izjava“ (eng. statements) odnosno analizu tekstova i rečenica koje čine tekstove s ciljem da se analiziraju i opišu pravila koja dominiraju korpusom tekstova. Slijedeći Foucaultov rad, Fairclough pojam diskursa razlaže na dva osnovna smisla: diskurs u apstraktnom smislu u jednini koji se odnosi na „domenu izjava“, i diskurs kao 
konkretna skupina izjava ili 'regulirana praksa' koja upravlja tom skupinom izjava (Fairclough 2003).

Kod analize diskurzivne prakse pažnja se obraća na međusobne odnose i povezanosti između tekstova, zatim okolnosti u kojima se proizvode tekstovi, načine na koji se ti tekstovi distribuiraju, načine na koji dopiru do čitatelja, odnosno kako ih oni shvaćaju, koriste i pri korištenju transformiraju.

Važan moment analize diskurzivnih praksi je analiza intertekstualnosti. Za Fairclougha (2006/1992) intertekstualnost predstavlja koncept koji je ključan za objašnjenje načina na koji dolazi do promjena u poretku diskursa. Foucault (2002) također spominje intertekstualnu povezanost između izjava, diskurzivnih formacija i diskursa te kako se oni miješaju u raznim interdiskurzivnim kombinacijama koje čine poredak diskursa, a koja se na praktičnoj razini tekstova može prepoznati kao intertekstualnost. Intertekstualnost je pojam koji Fairclough preuzima od Julije Kristeve. Ona se koristi tim pojmom kako bi „prevela“ rad Mikhaela Bakhtina zapadnome krugu čitatelja (Fairclough 2006/1992). Mikhail Bakhtin je razvio teoriju žanrova i s njome povezan ,translingvistički“ pristup analizi teksta, u kojem ukazuje na važnost sagledavanja tekstova kao proizvoda kombiniranja prethodno formuliranih tekstova, ali i kao izvora sastavljanja budućih tekstova. I kod Bakhtina, kao i kod Foucaulta, dolazi do propitivanja individualnog autora teksta. Svi su komunikacijski događaji, bilo pisani ili izgovoreni, prerade, obrade, dodavanja i preuzimanja nekih prijašnjih tekstova. Iz svakog teksta progovara mnoštvo autora, a njihovi komunikacijski izrazi anticipiraju i nude podlogu i sadržaj nadolazećim tekstovima. Možemo reći da je svaki tekst ili svaki govor samo jedna karika u nelinearnom nizu drugih tekstova i govora (Fairclough 2006/1992). „Naš je govor (...) ispunjen riječima drugih, varijabilnim stupnjevima drugosti i različitim stupnjevima vlastitosti, različitim stupnjevima svijesti i odmaka/otuđenosti. Riječi drugih donose sa sobom vlastiti izraz, vlastiti prosudbeni ton, koji mi asimiliramo, prerađujemo i na koji stavljamo drugačije naglaske“" (Bakhtin 1986: 89; prema Fairclough 2006/1992: 102). Intertekstualnost predstavlja jedan od ključnih koncepata u kritičkoj analizi diskursa jer je na njega naslonjen mehanizam promjene poretka diskursa. Fairclough parafrazira Kristevu kada kaže da su tekstovi jedan od gradbenih artefakata povijesti jer se sastoje od prošlih tekstova te time predstavljaju neku vrstu povijesnog svjedočenja određenog perioda. Svi su tekstovi također i pokretači promjena jer oni prošle tekstove koji ih konstituiraju ujedno mijenjaju i prilagođavaju te na taj način sačinjavaju povijest, utječu na buduće tekstove i pokreću promjene. Fairclough tu postavlja određena ograničenja na to u kojoj se mjeri društvena promjena može pripisivati promjenama proizašlima 
iz intertekstualnosti jer produktivnost kombiniranja i rekombiniranja tekstova kroz intertekstualnost nisu bezgranični u svojoj produktivnosti. Kreativna jezična aktivnost ljudi koja se izražava kroz intertekstualnost limitirana je hegemonijom uspostavljenom u poredcima diskursa. Naime, produktivnost intertekstualnosti ograničavaju uspostavljeni društveni odnosi i raspodjela moći koja se manifestira u postojećim društvenim praksama i strukturama. Međutim, kako je već spomenuto ranije, kada je bilo riječi o pojmu hegemonije i njegovoj važnosti u kritičkoj analizi diskursa, ona podrazumijeva prostor na kojem se odvijaju borbe za premoć nad proizvodnjom diskursa i za uspostavljanjem dominantnog diskursa, odnosno dominantne perspektive i slike svijeta prema kojem se ravnaju kulturni, diskurzivni ili povijesni jezični artefakti. Uspostavljena hegemonija nikada nije apsolutna, ona je samo prevladavajuća u određenom stupnju i da bi se održala zahtijeva pristanak sudionika. Uspostavljena je hegemonija diskursa podložna svrgavanju, odnosno u svakom trenutku postoje, nastaju i nestaju oponirajući diskursi koji nude vlastitu sliku i tumačenje značenja društvenih odnosa i društvenog poretka. U tom je smislu kreativnost manifestirana u intertekstualnosti aktivno sputana priječećom snagom hegemonije, pa je i promjena koju intertekstualnost donosi ovisna o specifičnim konstelacijama društvenih i diskurzivnih odnosa koji onda združenim djelovanjem mogu proizvesti promjene ili očuvati hegemonijski poredak.

Intertekstualnost se dakle odnosi na preuzimanje, ugrađivanje i druge odnose između tekstova. No Fairclough ističe da se intertekstualnost komunikacijskog događaja ili teksta „može shvatiti kao uključivanje potencijalno složenih odnosa koje /tekst/ ima s konvencijama (žanrovima, diskursima, stilovima, i tipovima aktivnosti) koje zajednički strukturiraju poredak diskursa“ (Fairclough 2006/1992: 103). Stoga možemo reći da tekstovi ostvaruju dvije vrste odnosa $\mathrm{u}$ terminima intertekstualnosti: a) odnose $\mathrm{s}$ drugim tekstovima (prošlima koji ih konstituiraju ili sastavljaju i budućima koje anticipiraju) te b) odnose sa spomenutim konvencijama koje čine neki poredak diskursa. Ovim odnosima možemo onda pridružiti dva oblika intertekstualnosti: a) manifestnu intertekstualnost; i b) konstitutivnu intertekstualnost odnosno interdiskurzivnost. Manifestnu intertekstualnost nalazimo kada su u nekom tekstu eksplicitno naznačeni tekstovi koji ga sastavljaju - drugi su tekstovi najčešće naznačeni navodnim znacima ili upućivanjem na izvor određenog dijela teksta. Konstitutivna intertekstualnost ili interdiskurzivnost odnosi se na stvaranje tekstova prema specifičnim diskurzivnim konvencijama određenog poretka diskursa. Konvencije poretka javnog diskursa sastoje se od izjava za javnost, konferencija za novinstvo, komentara određenih društvenih aktera i slično. 
Kada je riječ o interdiskurzivnosti (konstitutivnoj intertekstualnosti), Fairclough govori o odnosima između teksta i konvencija poretka diskursa, to jest odnosu analiziranog teksta sa žanrovima, diskursima u užem smislu i stilovima. U Faircloughovom analitičkom okviru, poredci diskursa su nadvisujuća instanca koja određuje pojedine tipove diskursa koji su određeni kao konfiguracija elemenata poredaka diskursa. Fairclough također pojašnjava kako se interdiskurzivnost može tražiti na različitim razinama općenitosti, pa ako krenemo od najviše razine, onda su to socijetalni poredak diskursa, institucijski poredak diskursa (Fairclough 2006/1992).

U ovom je radu u središtu nastojanje da se opiše i odredi poredak diskursa o fleksibilizaciji tržišta rada analizom komunikacijskih događaja koje čine članci u dnevnim novinama kao primjeri, odnosno manifestacije javnog diskursa o fleksibilizaciji tržišta rada. Svaki tekst, ili svaki komunikacijski događaj, jedinstvena je kombinacija intertekstualnosti i svoju nastanak i značenjsku koherentnost temelji na smještenosti u konstelaciju već postojećih tekstova. U okviru predložena Faircloughova modela kritičke analize diskursa, intertekstualnost je važan pokazatelj interdiskurzivnosti, odnosno spleta diskursa na koji se pojavljuje u datom komunikacijskom događaju. Možemo dakle reći da se materijal koji analiziramo sastoji od različitih žanrova i podžanrova koji čine uzorak odabranih tekstova, te da se sastoji od različitih žanrova i diskursa koji tvore javni diskurs a ogledaju se u interdiskurzivnosti i intertekstualnosti pojedinačno analiziranih tekstova. U kritičkoj analizi diskursa, a osobito u Farcloughovoj varijanti kritičke analize diskursa, poredak diskursa moguće je označiti i pojmom kojim ga definira Foucault i to kao „kompleksnu konfiguraciju diskursa i žanrova unutar jednog društvenog polja ili društvene institucije“, odnosno ,različiti diskursi koji ugrubo pokrivaju isto područje, područje koje se svaki diskurs natječe ispuniti značenjem na svoj način“ (Jørgensen i Phillips 2002: 141). Kada govore o konstrukciji analitičkog okvira za diskurzivna istraživanja, Jørgensen i Phillips (2002) započinju najopćenitijom apstraktnom definicijom diskursa kao procesa kreiranja značenja unutar određenog područja, odnosno određene domene. Prema postavkama kritičke analize diskursa u pojedinim domenama nalazimo više diskursa koji se natječu za primat uspostave značenja. Kritička analiza diskursa utilizacijom teorijske konstrukcije poretka diskursa također omogućuje uvid u uravnoteženost uključenosti različitih glasova koji sudjeluju u stvaranju diskursa prisutnih u proučavanom poretku i koliko uopće pristupa imaju javnom diskursu i kolika se težina pridaje njihovim doprinosima. Kada je riječ o spletu diskursa koji tvore neki predak diskursa, često se nailazi na problem razgraničavanja tih diskursa, na što upozoravaju Jørgensen i Phillips (2002), pa tako navode primjer Normana 
Fairclougha koji u jednoj te istoj analizi identificira „,vojni diskurs“, „,diskurs vojnog napada“ i „fiktivni diskurs vojnog napada“. Prema njihovom prijedlogu, rješenje ovog empirijskog problema jest da se diskurs uzima kao analitički koncept, odnosno „kao entitet koji istraživač projicira na zbilju kako bi kreirao istraživački okvir“, stoga diskurs ne nalazimo u stvarnosti već je on analitički konstruiran polazeći od određenih hipoteza i istraživačkih pitanja (Jørgensen i Phillips 2002: 143, 147).

Za potrebe ovog rada, preuzeta je koncepcija poretka diskursa modela kritičke analize diskursa Normana Fairclougha i to se posebno odnosi na način na koji se pristupa analizi diskurzivnih praksi u kontekstu društvenih praksi (Slika 2.1). Valja napomenuti da je, u skladu s preporukama kritičke analize diskursa, Faircloughov okvir za analizu prilagođen istraživačkom problemu diskurzivnog aspekta fleksibilizacije tržišta rada u Hrvatskoj te ne sadrži sve komponente Faircloughove kritičke analize diskursa, a osobito ne onu koja se odnosi na analizu lingvističkih karakteristika predmetnih tekstova. Lingvističku analizu tekstova $\mathrm{u}$ radu zamjenjuje analiza tema tekstova novinskih članaka s obzirom na to da je naglasak na sociološkoj analizi smještenosti diskurzivnih praksi u društvene prakse provođenja fleksibilizacije tržišta rada. U ovom se radu kritička analiza diskursa provodi prema ranije opisanom općem Faircloughovom modelu, odnosno analitičkom okviru kritičke analize diskursa koji podrazumijeva analizu teksta i tema koje se pojavljuju u člancima, zatim analizu diskurzivnih praksi ili interdiskurzivnu analizu kao neku vrstu analize argumenata koji u skladu s određenim ideološkim predznacima ili nagnućima govore u prilog ili protiv određene vizije fleksibilizacije tržišta rada te naposljetku analizu društvenih praksi u koju su uključeni podaci o stanju hrvatskog tržišta rada nakon provođenja reformi zakonodavnog okvira. 


\section{NEOLIBERALNI DISKURS I FLEKSIBILIZACIJA TRŽIŠTA RADA}

\subsection{Neoliberalni diskurs}

\subsubsection{Konceptualizacija neoliberalizma}

Konceptualizacije neoliberalizma, barem one nastale u posljednjih dvadesetak godina, podrazumijevaju kritičko, odnosno negativno odnošenje prema konceptu neoliberalizma i pojavama koje on označuje. Posljedica tog, moglo bi se reći jednostranog odnosa prema konceptu, je sve teže povezivanje teoretizacija o neoliberalizmu s neoliberalnim praksama. S obzirom na negativan predznak samog koncepta, postoji tendencija izbjegavanja korištenja termina kao pozitivne, pa čak i kao neutralne dezignacije. U tom smislu, nijedan ekonomist neće sebe okarakterizirati neoliberalnim, kao što političke elite neće opisivati javne politike koje konstruiraju i provode kao neoliberalne. Tako se često doima da ono što mnogobrojni znanstvenici pretežno lijeve provenijencije kritiziraju, uopće niti ne postoji. Najopćenitija definicija koja se može izvesti iz većine teorijskih konceptualizacija jest ta da je neoliberalizam projekt provođenja skupa preporuka koje čine relativno koherentnu agendu politika u čijem je središtu deklarirana, moglo bi se reći ideološka i bezuvjetna predanost ekonomskoj regulaciji koja se zasniva na principu slobodnog tržišta nasuprot principu regulacije koji podrazumijeva, uz samo tržište, i određeni niz neposrednih intervencija države kada je riječ o raspodjeli društvenih resursa.

Već iz gore izvedene definicije neoliberalizam se može prepoznati kao fenomen s više dimenzija, pri čemu teoretičari najčešće ističu dvije ili tri. Neoliberalizam je zapravo ekonomsko-politički projekt koji možemo razložiti na dva elementarna dijela, a to je neoliberalni paket javnih politika ili neoliberalne prakse te neoliberalna ideologija, odnosno neoliberalna doktrina (Cahill 2014). Spomenutima dvjema dimenzijama moguće je dodati i shvaćanje neoliberalizma kao umijeća vladanja, to jest neoliberalnog governmentaliteta kako ga je u svojim predavanjima opisao Michel Foucault, a koja su sabrana i izdana 2008. godine pod nazivom Rođenje biopolitike.

Neoliberalizam možemo definirati kao skup praksi, odnosno neoliberalnu agendu koju čini konkretni skup javnih politika. Neoliberalna se političko-ekonomska agenda sastoji od četiri skupine smjernica koje zagovaraju deregulaciju ekonomije, liberalizaciju trgovine i 
industrije, privatizaciju poduzeća u državnom vlasništvu, tržišne nadomjeske u javnom sektoru, internacionalizaciju i smanjivanje izravnog oporezivanja (Jessop 2016). Ako pristupamo neoliberalizmu kao ideologiji ili doktrini, onda se ona ponekad dovodi u usporedbu s marksizmom kao svojim naličjem, s kojim je, osim velikog broja značajnih razlika, spaja činjenica da se usredotočuje na ekonomske odnose te postavlja proizvodnju i raspodjelu materijalnih dobara u središte ljudskoga iskustva (Steger i Roy 2010). Karakteristike neoliberalne doktrine možemo ukratko opisati kroz niz ključnih koncepata u koje spadaju: a) naglašavanje važnosti tržišta i tržišnog poretka kao najučinkovitijeg i nezamjenjivog mehanizma za optimalnu alokaciju resursa i čuvanje individualnih sloboda, b) protivljenje državnoj intervenciji, c) inzistiranje na pravnoj državi koja štiti uspostavljeni ekonomski poredak i privatno vlasništvo te d) zaštita privatnog vlasništva koja je povezana s postavljanjem pojedinca ispred kolektiva (Turner 2008). Ako neoliberalizmu pristupimo kao umijeću vladanja ili governmentalitetu onda pod time podrazumijevamo vladavinu koja ističe važnost individualnih interesa, natjecateljskog duha i decentralizacije. Neoliberalna vladavina djeluje po principima preuzetima iz trgovine i poslovanja, tj. upravljanja tvrtkom, pri čemu se naglašava važnost, primjerice ,razvoja strateških planova i upravljanja rizikom“ usmjerenih na ostvarenje dobiti, postavljanje kvantitativnih ciljeva te uvođenje modela „racionalnog-izbora“ (Steger i Roy 2010).

Sociolog Bob Jessop (2016) definira neoliberalizam naglašavajući njegovu ekonomsku i političku dimenziju, u kombinaciji s načinima na koje se on mijenjao kroz povijest, pa u tom smislu govori o procesu neoliberalizacije:

„Neoliberalizacija je specifični ekonomski, politički i društveni projekt koji ima tendenciju rasuđivati o svim ekonomskim aktivnostima u terminima profitabilnosti i svim društvenim aktivnostima u terminima njihova doprinosa diferencijalu akumulacije kapitala. Ovo bi moglo upućivati na to da neoliberalizam promiče primat ekonomskog, ali zato što njegovo širenje i reprodukcija zahtijevaju stalnu potporu države i, dapače, često podrazumijevaju ono što je Weber (1975) nazvao 'političkim kapitalizmom', moglo bi se ustvrditi da promiče primat političkoga“ (Jessop 2016: 412).

U skladu s pojmom širenja neoliberalne vrste političkog kapitalizma, odnosno pojmom neoliberalizacije, Jessop (2016) razlikuje četiri osnovna povijesna oblika neoliberalizma. Prvi se oblik manifestira kroz „,neoliberalne sustave transformacije“ u državama bivšeg Sovjetskog saveza, unutar kojih je moguće razlikovati dvije varijante neoliberalizacije kakve su se na 
primjer odvijale u Rusiji i Poljskoj. U Rusiji je provedena takozvana neoliberalna šok terapija prema načelima kreativne destrukcije čikaške škole, dok je u Poljskoj provođena „tržišna terapija bez šoka“ prema ordoliberalnoj matrici. Drugi oblik neoliberalizacije Jessop (2016) naziva „neoliberalnim promjenama režima“, koji se odnose na transformaciju fordističkog režima akumulacije kojeg je karakterizirao društveni pakt između rada i kapitala, u sustav koji provodi neoliberalnu agendu politika kako bi proizveo ekonomsku raspodjelu koja favorizira kapital u odnosu na rad. Primjeri ovog oblika neoliberalizacije su tačerizam i reganomika, zatim približno slične transformacije ekonomskih sustava u Australiji, Novom Zelandu, Kanadi, i to često pod pokroviteljstvom centralno lijevih političkih opcija u formi politike „trećeg puta“. Početak je tih transformacija započeo u Južnoj Americi pod pokroviteljstvom zapadnjačkih ekonomskih think tankova ili vojnih diktatura. Takva je neoliberalizacija većinom bila uspješna u svojim nastojanjima koja su rezultirala stagnacijom realnih plaća, smanjivanjem usluga koje je pružala socijalna država, kao i povećanjem osobnog duga zbog kupovine nekretnina te ulaganja u obrazovanje, zdravlje ili mirovine. Treći se tip neoliberalizacije može povezati s prvim oblikom, a podrazumijeva promjene u režimima akumulacije koje se odvijaju zbog poticaja koji dolaze izvana, od transnacionalnih ekonomskih organizacija koje uživaju podršku svjetskih kapitalističkih sila i poslušnost nacionalnih političkih i ekonomskih elita (Jessop 2016). Neoliberalizacija ovog tipa koncentrira se u tranzicijskim zemljama i zemljama u razvoju koje čine afričke i azijske zemlje te zemlje središnje i istočne Europe, a odvija se prema smjernicama konsenzusa iz Washingtona kao uvjeta za primitak novčane pomoći od organizacija kao što su Svjetska banka ili MMF. Ovaj oblik procesa neoliberalizacije podrazumijeva i određene nacionalne otpore neoliberalizmu kao posljedice usporedbi s prijašnjim iskustvima drugih država. I naposljetku četvrti oblik čija se transformacija sastoji od djelomičnih prilagodbi i podešavanja koja se primjenjuju dozirano i koja su u određenoj mjeri reverzibilna, a predstavljaju nastojanja političkih elita da usklade uspostavljene socijalne modele s izazovima globalizacije i gospodarskih kriza. Primjeri ove neoliberalizacije nalaze se u nordijskim zemljama kao i u Njemačkoj. Iako se za ove promjene može istaknuti da su u određenoj mjere reverzibilne, na primjeru Njemačke moguće je prepoznati proces njihove stabilizacije u neoliberalni režim, i to kroz akumulaciju institucionalizacija neoliberalnih praksi koje je onda protekom vremena sve teže modificirati natrag u ekonomske sustave primarno socijalnog usmjerenja, od kojih je reforma započela.

Sam pojam neoliberalizma teško je jednoznačno odrediti s obzirom na mnoštvo teorijskih perspektiva koje se njime bave. Različitost teorijskih perspektiva proizvela je veliki 
broj znanstvenih radova i istraživanja na širokom području društvenog života i djelovanja. Sve perspektive spomenutih istraživanja shvaćaju neoliberalizam na sebi svojstvene i različite načine. Zato prije samog pokušaja donekle sistematiziranog ocrtavanja sadržaja neoliberalne ideologije i karakteristika samog neoliberalnog diskursa, važno je mapirati određene teorijske perspektive koje različito pristupaju neoliberalizmu kako bismo na neki način stabilizirali kaotičnost upotrebe i shvaćanja koncepta neoliberalizma. Pregledom literature o neoliberalizmu, ustanovljeno je da je tek u posljednjih nekoliko godina, od 2016. naovamo, došlo do značajnijih pokušaja sistematizacije istraživačkih poduhvata koji se bave neoliberalizmom, pa su tako objavljena dva priručnika o neoliberalizmu pod nazivima The Handbook of Neoliberalism u izdanju Routledgea iz 2016. godine i The SAGE Handbook of Neoliberalism iz 2018. godine, kao i knjiga Keana Bircha iz 2017. godine pod nazivom The Research Agenda for Neoliberalism, izdavačke kuće Elgar. Kean Birch (2017) se u svojoj knjizi osvrće na probleme rada s konceptom neoliberalizma; na to što on zapravo znači, koje su osnovne značajke njegovih doktrina te tko su osobe koje se mogu smatrati predstavnicima neoliberalizma.

Kean Birch (2017) opisuje nastanak i razvoj upotrebe koncepta neoliberalizma, kao i samu definiciju neoliberalizma iz različitih te, kako on sam naglašava, dominantno kritičkih perspektiva. U knjizi A Research Agenda for Neoliberalism, Birch (2017) nastoji sintetizirati analitičke trendove neoliberalizma, pa opisuje sedam različitih kritičkih shvaćanja neoliberalizma, od kojih svaka nudi vlastitu konceptualizaciju neoliberalizma, a to su:

a) perspektiva Michela Foucaulta koja neoliberalizam promatra kao governmentalitet;

b) marksistička perspektiva i klasna analiza;

c) ideacijska analiza;

d) povijest i filozofija ekonomike;

e) institucionalna analiza;

f) teorija države i regulacijska škola;

g) procesualna perspektiva, neoliberalizacija i antropogeografija.

\section{Michel Foucault i neoliberalizam kao governmentalitet}

Foucault je bio među prvim teoretičarima koji je svoja istraživanja usmjerio na konceptualizaciju neoliberalizma, a njegova su predavanja o toj temi iz 1978/79. godine objavljena na engleskom jeziku 2008. godine pod nazivom The Birth of Biopolitics (Rođenje 
biopolitike). Foucault se u svojim predavanjima razvijanjem i obrazlaganjem pojma governmentaliteta, odnosno umijeća vladanja, usredotočio na povijesni razvoj liberalizma, pa tako i na njegove moderne izdanke (Birch 2017: 65). Modernu verziju liberalizma, odnosno neoliberalizam, Foucault je podijelio na dvije varijante, a to su njemački ordoliberalizam i američki neoliberalizam čije je teorijske fundamente nalazio u zapisima čikaške škole, s posebnim naglaskom na pisanja ekonomista Garyja Beckera. Foucault je proučavao neoliberalizam u terminima governmentaliteta, odnosno umijeća vladanja, koji se odnose na tehnike koje pojedine vlade koriste za podčinjavanje svojih građana, odnosno oblikovanje njihova ponašanja u društvu, i to kombiniranjem različitih oblika tehnologija i racionalnosti. Uspoređujući neoliberalizam u okviru navedenog razlikovanja, Foucault je ustanovio da američki neoliberalizam i njemački ordoliberalizam imaju određene zajedničke točke, a to se najvećim dijelom odnosi na ideološku predanost tržišnom natjecanju i tržišnom mehanizmu raspodjele ekonomskih i društvenih resursa. Međutim, oni se razlikuju prema tehnologijama moći, kao što su zakoni i druge vrste regulacije, pa tako njemački ordoliberalizam, stavlja naglasak na državom poduprijeto funkcioniranje tržišta, odnosno na stvaranje i funkcioniranje „modela socijalnog tržišta”. Američki neoliberalizam pak naglašava potrebu podređivanja države tržištu, i počiva na ideji širenja tržišnog natjecanja na sve aspekte društvenog života, kao i živote pojedinaca (Birch 2017: 65-66).

U kontekstu analize governmentaliteta, to jest načina na koje postaje moguće vladati građanima oblikovanjem misaone strukture kao mentalnog oslonca u svakodnevnom funkcioniranju pojedinaca, kao i kroz shvaćanja društva i sebe samih te ponašanja koja iz tih shvaćanja proizlaze, Foucault smatra da svaki od navedenih oblika neoliberalizma ima svoje, donekle slične sustave racionalnosti koji se temelje na tržišnom natjecanju te tehnologije moći, odnosno određena pravila i zakone koji ta pravila reguliraju, što sve zajedno čini ono što on naziva governmentalitetom (Birch 2017).

\section{Marksizam i klasna analiza}

U najutjecajnije i najprepoznatljivije predstavnike ove perspektive ubrajaju se David Harvey, Dumenil i Levy, Laclau i Mouffe, zatim Bastiaan van Apeldoorn te David Cahill. U okviru marksističke perspektive moguće je razdvojiti dva različita shvaćanja neoliberalizma. Prema jednom shvaćanju, kakvo zastupa između ostalih i David Harvey, neoliberalizam je definiran kao ,projekt povratka klasne moći elita pri čemu neoliberalne ideje i principi (na primjer, natjecanje na slobodnom tržištu) predstavljaju samo ideološki ukras povrh klasne borbe koja se odvija u pozadini” (Birch 2017: 66). Neoliberalizam je za predstavnike radikalno 
lijeve marksističke struje samo sustav ideja koji služi za opravdanje i legitimaciju programa čiji je krajnji cilj pogodovati elitama $u$ klasnom sustavu. Harvey, primjerice naglašava da $u$ slučajevima kada se principi doktrine neoliberalizma ne podudaraju s interesima najbogatijih koji profitiraju od uspostavljenog kapitalističkog sustava koji proizvodi ekonomsku nejednakost i prema toj nejednakosti jednako tako nejednako razdjeljuje moć u društvu, neoliberalna se doktrina bez oklijevanja potiskuje. Takav zaključak Harvey izvodi iz nepodudaranja neoliberalne doktrine o odnosu države prema ekonomiji i neoliberalnih praksi u kojima država ima značajnu ulogu u provođenju neoliberalnih politika deregulacije, liberalizacije i privatizacije. Praksa je, prema radikalno lijevim misliocima, pokazala da je država u neoliberalnom sustavu akumulacije postala instrument za provođenje partikularnih klasnih interesa u praksi. Neoliberalnom se ideologijom tako opravdavaju snižavanje poreza za bogate, rast nezaposlenosti i nejednakosti te stagniranje plaća.

Na primjer, Dumenil i Levy su na temelju empirijske analize došli do zaključka da je neoliberalizam započeo svoj uspon $\mathrm{u}$ isto vrijeme kada su resursi jedan posto najbogatijih postali ugroženi i to početkom 1970-ih godina. Prema Dumenilu i Levyju neoliberalizam predstavlja ,projekt u kojem kapitalističke klase stvaraju savez s menadžerskim klasama kako bi povratile prihode jedan posto najbogatijih" (Birch 2017: 67). Harvey te Dumenil i Levy smatraju da je dokaz uspjeha navedenog projekta širenje financijalizacije ekonomije te rastakanje socijalne države i sveopći gubitak radničkih prava i zaštita koji su izboreni u poslijeratnom razdoblju. Kao što je već prije naznačeno, ova struja radikalnije lijevih teoretičara drži da iza neoliberalizma ne stoji težnja za primjenom neoliberalne doktrine, odnosno teorije slobodnog tržišta, tržišnog natjecanja, ili poduzetništva već borba za održanjem dominacije „1 posto najbogatijih“ svim dostupnim ideološkim i političkim sredstvima.

Druga struja marksističke perspektive pretežito se temelji na pisanjima teoretičara Bastiaana van Apeldoorna i Davida Cahilla. Oni definiraju neoliberalizam kao političkoekonomski projekt, odnosno režim politika koji se sastoji od privatizacije, deregulacije, smanjenja radničkih prava te politike štednje. Obojica akademika uvode u analizu neoliberalizma pojam „uklopljenosti” koji preuzimaju od Karla Polanyja, pa se tako koriste sintagmom ,uklopljenog neoliberalizma” koja podrazumijeva i vidi neoliberalizam kao režim politika koji je srašten s određenim već postojećim društvenim praksama i institucijama. Tako Cahill (2014) smatra da se neoliberalizam održao i nakon gospodarske krize 2007. godine kada su razotkrivene sve slabosti neoliberalne organizacije ekonomije. Neoliberalizam se nije transformirao u neki drugi oblik organizacije kapitalističke akumulacije zato što je uklopljen u 
tri sfere društvenih odnosa koje ga čine otpornim na promjene ili na zamjenu potencijalnim alternativnim pristupima organizacije ekonomskog sustava; te tri sfere su klasni odnosi, institucije i ideologija. Cahill (2014) smatra da iza neoliberalnih politika stoje interesi korporacija koji iskorištavaju državnu moć kao instrument provođenja politika koje odgovaraju njihovim poslovnim interesima. Bastiaan van Apeldoorn (2009) pak analizira utjecaj transnacionalnih elita na stvaranje neoliberalnog režima politika kao okvira za ostvarenje specifičnih klasnih interesa osobito se usredotočivši na neoliberalne politike u Europskoj uniji koje su pod jakim utjecajem njemačke paradigme ordoliberalizma sa svojim zagovaranjem modela socijalnog tržišta.

\section{Ideacijska analiza}

Ideacijska perspektiva pripada socijalnom konstruktivizmu te kao takva naglašava da je cjelokupna oblast „političke ekonomije kakvom ju znamo i percipiramo, zapravo društvena konstrukcija naših djelovanja, ponašanja i pretpostavki” (Birch 2017: 68). Osnovna postavka ideacijske perspektive, koja se onda može primijeniti i na neoliberalizam jest ta, da ideologija nije samo sredstvo legitimacije postojećih politika kojima vladaju klasni interesi, već da neoliberalne ideje imaju određenu društvenu moć i tendenciju da utječu na društvene, ekonomske i političke tokove, odnosno da neoliberalni diskurs kao artikulacija specifičnih ekonomskih ideja utječe na oblikovanje ključnih javnih politika. Neoliberalizam je u okviru ovog pristupa definiran kao skup ekonomskih ideja koje imaju performativnu moć. Birch (2017) ovu perspektivu povezuje s akademicima na području političke znanosti, a među predstavnicima ove perspektive najistaknutiji je Mark Blyth, koji neoliberalizmu pristupa kroz istraživanje povijesti ekonomskih ideja neoliberalizma te načina na koji se kroz te ideje identificiraju ekonomski problemi te oblikuju politike koje onda predstavljaju pokušaje rješavanja percipiranih problema. Neoliberalne ideje dakle možemo zamišljati kao neku vrstu oslonca i orijentira u odnosu na koje društveni akteri percipiraju društvene ili ekonomske okolnosti te prihvaćaju niz mogućnosti na koje se ti akteri mogu postaviti unutar datih, na „,neoliberalni način“ konstruiranih okolnosti. Cilj je ideacijske analize ustanoviti zašto se mijenjaju institucije. Mark Blyth u svojoj knjizi Velike transformacije iz 2002. godine, analizira tranziciju institucija iz kejnzijanizma u neoliberalizam i to u Sjedinjenim Američkim Državama i Švedskoj. Blyth zaključuje da je tijekom uspona neoliberalizma došlo do stapanja različitih ekonomskih teorija, odnosno monetarizma, teorije racionalnih očekivanja i ekonomike potražnje što je dovelo do promjene u institucijama jer je stvorilo uvjete za promjenu pristupa društvenim problemima, mogućim rješenjima i kreiranju javnih politika (Birch 2017: 68). 


\section{Povijest i filozofija ekonomike}

Birch (2017) je radove poznatog povjesničara neoliberalizma Philipa Mirowskog svrstao u pravac koji je nazvao povijest i filozofija ekonomike. Naime, Mirowski i znanstvenici s kojima je surađivao bavili su se proučavanjima neoliberalizma kao epistemologije. U okviru ovog pristupa neoliberalizam je definiran kao „kolektivna misao” jer Mirowski i suradnici dolaze do zaključka da je neoliberalizam entitet kojeg je teško konceptualno stabilizirati s obzirom na nedostatak obilježja kao što su koherentnost i statičnost određenog seta ideja, principa ili teorija koji bi mu davali neku dohvatljivu prepoznatljivost i cjelovitost (Birch 2017: 69). Neoliberalizam, odnosno spomenuta „kolektivna misao”, predstavlja način razumijevanja svijeta, odnosno epistemičku zajednicu koja se sastoji od više različitih razumijevanja ekonomije i društveno-političkog života, i koja se mogu na najopćenitijoj razini podijeliti na Hayekovu perspektivu Austrijske škole, i Friedmanovu perspektivu Čikaške škole. Te su se dvije struje udružile pod okriljem Montpelerinskog društva te su dalje reproducirale svoje neoliberalne ideje i poglede na ekonomiju utemeljenjem organizacija koje su predstavljale svojevrsne rasadnike neoliberalne perspektive, odnosno istraživačke centre, institute, fondacije i slično. Utemeljene su organizacije odigrale ključnu ulogu u etabliranju neoliberalnog pogleda na organizaciju ekonomije i njegovu naturalizaciju među masama ljudi, iako, kako ističe Mirowski prema Birchu (2017) ti su pogledi često bili mijenjani i reformulirani kako bi se prilagodili različitim društvenim okolnostima remeteći kontinuitet neoliberalne doktrine i misli. Iz tog je razloga, prema zastupnicima ove perspektive, izlišno pokušavati jasno opisati neoliberalni identitet jer je on bio podložan različitim transgresijama granica diskursa, često i s visokim stupnjem različitosti od ishodišnih shvaćanja koja bi se mogla nazivati originalno neoliberalnima jer pripadaju teorijama sastavljenim od djela osnivača Montpelerinskog društva.

\section{Institucionalna analiza}

Kao predstavnike institucionalne analize, Birch navodi teoretičare kao što su Dowd i Dobbin te Campbell i Pedersen, koji definiraju neoliberalizam kao politički projekt koji podrazumijeva ,institucionalne promjene na razini koja nije viđena od razdoblja netom nakon drugog svjetskog rata. Takve institucionalne promjene obuhvaćaju restrukturiranje države, radnih odnosa, tržišta, regulacija i tako dalje“ (Birch 2017: 70). Institucionalna analiza neoliberalizma utemeljena je na polazištima ekonomske sociologije, a osnovna im je pozicija kritika pogrešnog uvjerenja da se ekonomske ideje mogu jednostavno prenijeti na društvene 
transformacije. Naime, neoliberalizam ne predstavlja jednostavnu transformaciju institucija prema unaprijed zadanim smjernicama kao dio procesa restrukturiranja. Naprotiv, neoliberalizam ne djeluje kao snaga izolirana od postojećih društvenih struktura i djelovanja; on djeluje na već postojeće institucije i ne izrađuje iz temelja nove institucije, pa se zato ne može utvrditi da je njihov razvoj unaprijed zadan i ostvaren prema unaprijed zamišljenoj neoliberalnoj agendi: tome između ostalog govori u prilog i velika varijacija u oblicima neoliberalnih političko-ekonomskih projekata $u$ različitim regijama i državama. U institucionalnoj analizi neoliberalizma razlikuju se dvije vrste institucionalizma, a to su historijski i organizacijski institucionalizam. Prema postavkama institucijske analize, neoliberalizam je prikladnije analizirati u okvirima organizacijskog institucionalizma jer on uključuje neformalne institucije kao što su norme, kultura i diskurs pri analizi društvenog svijeta, dok historijski institucionalizam zamišlja postanak institucija kroz unaprijed zadane smjerove razvoja. Zastupnici ovog pristupa zagovaraju primat organizacijskog institucionalizma $\mathrm{u}$ analizi neoliberalizma jer on ostavlja prostor za konflikte i osporavanja određenih puteva razvoja. Prema ovoj perspektivi, ne postoji način na koji se može predvidjeti kako će projekt razvoja neoliberalizma završiti, iako je možda započeo s istim nakanama sadržanima u smjernicama neoliberalne agende. Ovakav pristup proučavanju neoliberalizma ima određenih prednosti koje podrazumijevaju otvaranje mogućnosti proučavanja različitosti i varijacija ustoličenja neoliberalizma kroz posebnost institucija zatečenih u različitim društvenim okolnostima nacionalnog odnosno regionalnog predznaka.

\section{Teorija države i francuska škola regulacije}

Perspektiva teorije države i francuske škole regulacije definira neoliberalizam kao oblik regulacije kapitalizma; usredotočivši se na transformacije kapitalizma od jednog režima akumulacije u drugi, teoretičari regulacijske škole osobito proučavaju transformaciju fordizma u postfordizam, pri čemu zaključuju da su društvene strukture koje su podupirale fordizam bile utemeljene na kejnzijanskim principima, dok je postfordizam kao režim akumulacije utemeljen na programu neoliberalnih politika koje ostvaruju stabilan akumulacijski režim prikladan postfordističkom društvenom, odnosno ekonomskom okruženju (Birch 2017: 71-72).

Perspektiva teorije države i francuske škole regulacije također čine neku vrstu institucionalne analize, i temelje se najvećim dijelom na radovima sociologa Boba Jessopa, koji se pak oslanja na francusku tradiciju teoretičara političke ekonomije koja čini Regulacijsku školu. Prema Jessopu se neoliberalizam može definirati kao heterogeni proces koji se sastoji od najmanje četiri oblika, a to su transformacija sustava, promjena režima, strukturalna prilagodba 
i prilagodba politika (Birch 2017). Kriza kejnzijanskih oblika regulacije i režima akumulacije dovela je do uspona neoliberalizma, a njegova se dominacija u formi regulacijskog mehanizma kapitalizma nastavila zbog ukorijenjenosti neoliberalnih politika u postojećim društvenim institucijama. Jessopov pristup ima određene sličnosti s ranije spomenutim institucijskim pristupom, iako ga razlikuje važnost države kojoj Jessop pripisuje regulaciju kapitalizma, dok institucionalni pristup naglašava ukorijenjenost institucija u društvu.

\section{Procesualna perspektiva, neoliberalizacija i antropogeografija}

Perspektiva neoliberalizacije proistječe iz znanstvenog područja antropogeografije, ali se uvelike oslanja na već spomenute teoretičare neoliberalizma, pa tako unutar priče o neoliberalizaciji nalazimo utjecaje marksističkih mislioca, prije svega Davida Harveya, radova sociologa Boba Jessopa, kao i poimanje neoliberalizma kao governmentaliteta. Ono što razlikuje antropogeografsku perspektivu od ostalih pristupa neoliberalizmu, definiranje je neoliberalizma kao procesa, odnosno neoliberalizacije - ,procesa restrukturiranja kojeg obilježavaju posebne socio-ekonomske sile i akteri, uključujući i privatizaciju, komodifikaciju i marketizaciju“, koji predstavlja „mobilizaciju državne moći u kontradiktornoj ekstenziji i reprodukciji vladavine koja nalikuje tržištu“ (Birch 2017: 73).

Najprepoznatljiviji predstavnici antropogeografske perspektive su Jamie Peck i Adam Tickell, poznati po opisu dviju faza neoliberalizacije. Prva, ili roll-back faza odvijala se tijekom 1980-ih godina kada su Margaret Thatcher i Ronald Reagan agresivno provodili politike privatizacije javnih usluga i državnih kompanija. Nakon toga, uslijedila je druga faza: roll-out neoliberalizacija koja je bila aktualna tijekom 1990-ih godina u Sjedinjenim Državama, Velikoj Britaniji i Njemačkoj, a odnosila se na politike trećeg puta i nastavak izgradnje državnih institucija na temelju neoliberalnih programa politika, kao i marketizacije javnih usluga.

$$
* * *
$$

Kao što sam Birch (2017) zaključuje, sve teorijske pozicije koje se bave neoliberalizmom, čine to iz kritičke perspektive. Iako naglašavaju različite aspekte neoliberalizma, navedene perspektive proizlaze iz sličnih pozicija, a u svojim se teorijskim konstrukcijama uvelike međusobno podupiru radovima navedenih teoretičara i njima svojstvenih konceptualizacija koje čine gradbene sastojke pojedinih teorijskih perspektiva. Iz tog razloga smatramo da nema smisla nastojati se pridržavati pojedine perspektive pri konceptualizaciji identiteta neoliberalne doktrine, odnosno ideologije i njezine artikulacije u formi neoliberalnog diskursa s obzirom na to da se neoliberalizam, odnosno neoliberalizacija 
konceptualizira na načine koji proistječu iz srodnih teorijskih pretpostavki i za koje se sve može reći da su utemeljene u nekoj varijanti kritičke teorije.

\subsubsection{Povijesni kontekst neoliberalne ideologije}

Kada govorimo o povijesnom razvoju neoliberalne ekonomske doktrine i neoliberalnog diskursa, začetak projekta razvoja i širenja neoliberalne misli različiti teoretičari smještaju u kontekst pada interesa za liberalne ideje i okretanje većine akademskih i političkih elita ka Keynesovoj ekonomici. Objava njegove knjige Kraj laissez-fairea, koja je izašla 1926. godine označava se početkom razdoblja ekonomskog kolektivizma kao reakcije na nemogućnosti vlada s početka 20. stoljeća da se na temelju naputaka i principa ekonomske doktrine laissez-fairea suoče s gospodarskom krizom koja je njihove narode ostavljala u neimaštini i siromaštvu. Negativno raspoloženje prema liberalizmu velikog dijela ekonomista i političara tog doba samo je osnažila velika gospodarska kriza i uvjerila da se za pokretanje gospodarstva valja okrenuti nekom obliku kolektivnog planiranja. To se kolektivno planiranje ostvarivalo kako u ekstremnim oblicima fašizma, tako i u kejnzijanski inspiriranim smjernicama za državom poduprijeto manipuliranje potrošnjom. Marginalizirani liberalni ekonomisti bili su uvjereni u totalitarne potencijale državom dirigirane ekonomije te su nastojali obraniti liberalnu misao od nasrtaja kolektivizma, bio on u liku nacističke Njemačke, sovjetske Rusije ili pak američke politike New Deala (Birch 2017). Za nastanak i razvoj neoliberalnih doktrine važno je zato istaknuti povijesni kontekst razvoja tih ideja koji je uvjetovao i sadržaj same doktrine jer se ona izgrađivala uvijek u odnosu s doktrinom socijalne države i kao reakcija na kejnzijanizam.

Tijekom 1930-ih godina također se odvijala i poznata debata o metodologiji između Maynarda Keynesa i Friedricha Hayeka. Tema je bila mogućnost planirane ekonomije, pri čemu je Keynes smatrao da država može i treba usmjeravati ekonomske procese dok je Hayek vjerovao u spontani poredak koji proizlazi iz sposobnosti tržišta da samo sebe regulira, odnosno koordinira. Hayekova knjiga Put u ropstvo, izdana je 1944. godine, a ideje koje su u njoj bile iznesene velikim su se dijelom zasnivale na teoriji Ludwiga Von Misesa iz Austrijske škole. Ono što Hayekovu knjigu izdvaja kao originalni tekst jest način na koji je pisana; politički motiviranim polemičnim stilom čiji je cilj bio utjecati na javno mnijenje tadašnje Britanije $i$ skrenuti put organizacije ekonomije što dalje od kolektivističkog kejnzijanskog pristupa. Bila je pisana pristupačnim jezikom nekarakterističnim za akademski tekst te je dala podlogu za argumentaciju britanskih konzervativaca koji su se borili protiv državnog planiranja. 
Poslijeratni su izbori u Britaniji donijeli pobjedu ljevice i smirivanje odnosa između rada i kapitala.

„Artikulacija pozitivne neoliberalne vizije bila je od samog početka isprepletena s eksplicitnom kritikom kolektivizma, kako u njegovu ekstremnom totalitarnom obliku, tako i u obliku kejnzijanskog i socijalnodemokratskog konsenzusa. Kejnzijanska je kriza tijekom 1970-ih bila događaj koji su neoliberali iščekivali dugo vremena. Pristupili su joj s gotovom teorijskom dijagnozom krize s jasnim političkim receptima za izlječenje“ (Phelan 2014: 41).

Neoliberalna doktrina imala je i nedvosmislene ideološke nakane te je tako poznato da su i Friedrich A. Hayek, a i Milton Friedman održavali kontakte s mnogim ljudima iz najviših poslovnih krugova koji su zapravo financirali njihov rad.

Kao formalni početak neoliberalizma uzima se jedan od dva povijesna okupljanja liberalno orijentiranih ekonomista. Jedno se od tih okupljanja odnosi se na događaj pod nazivom „Kolokvij Waltera Lippmana“ koji se održao 1939. godine u Parizu. Kolokvij je bio namijenjen diskusiji o knjizi Waltera Lippmana pod nazivom Dobro društvo, u kojoj je autor napadao kolektivizam kao put u tiraniju, istovremeno podupirući liberalne teze kao pretpostavke za razvoj društva utemeljenog na liberalnim principima za 20. stoljeće. Na kolokviju je sudjelovalo dvadesetak ljudi, većinom akademika, državnih službenika i poslovnih ljudi, kao i nekolicina poznatih europskih liberala, među kojima je bio i Friedrich Hayek čija je kasnija knjiga Put u ropstvo promicala vrlo slične teze kao i Dobro društvo (Birch 2017).

S početkom drugog svjetskog rata, europski su se liberali raselili po svijetu zbog opasnosti nacističkog režima, a neki su, uključujući i Hayeka (koji se još od 1931. godine bio nastanio u Londonu) otputovali i u Sjedinjene Američke Države, gdje su njihove neoliberalne ideje naišle na plodno tlo i privukle pozornost mnogih američkih poslovnih ljudi. Jedan od njih bio je i Harold Luhnow, koji je vodio i Fond Williama Volknera, preko kojeg je Luhnow donirao velike svote novca akademicima, organizacijama i publikacijama koje se zalagale za osporavanje državnog utjecaja na ekonomiju, ali i protivile komunizmu na temelju kršćanski orijentirane filozofije (Birch 2017). Pritom je važno naglasiti veliku, ali ponekad zanemarenu ulogu koju su u širenju neoliberalnih ideja imali poslovni ljudi, a koji su između ostalog održavali snažne veze s neoliberalima Hayekom i Friedmanom primjerice, čije su akademsko djelovanje i diseminaciju ekonomskih ideja novčano podupirali. 
Luhnow je također financirao okupljanje osnivača Društva Mont Pelerin 1947. godine, u koje se ubrajaju Friedrich Hayek, Ludwig von Mises, Karl Popper, Milton Friedman te drugi ekonomisti, pravnici i društveni znanstvenici koji su smatrali da se društvo slobodno od totalitarnog potencijala države može omogućiti jedino samoregulirajućim tržišnim mehanizmima koji će nadomještati državnu regulaciju te garantirati individualne slobode (Mirowski i Plehwe 2009). Nakon tih formalnih početaka, neoliberalizam se nastavio razvijati kao reakcija na kejnzijansko zagovaranje državne regulacije i kontrole modernog kapitalizma: ekonomsku politiku koja je bila uvriježena od kraja drugog svjetskog rata pa sve do polovice 1970-ih godina 20. stoljeća (Esping-Andersen 2003; Puljiz 2006). Nasuprot kejnzijanskom shvaćanju uloge države i tržišta, neoliberalna se politika zalagala za deregulaciju nacionalnih ekonomija, liberalizaciju međunarodne trgovine te stvaranje jedinstvenog globalnog tržišta, a sve predvođeno idejom o ,idealu 'samoregulirajućeg tržišta', kao glavnog pokretača individualne, racionalne težnje za bogatstvom“ (Steger i Roy 2010). Širenje neoliberalnih ideja odvijalo se kroz utemeljivanje mnogih međunarodnih i nacionalnih institucija, također financirano od poslovnih ljudi od kojih je osim, Ludhowa, među najznačajnijima bio i Antony Fisher koji je novčano potaknuo osnivanje Instituta za ekonomske odnose (IEA) 1955. godine, a čija je zadaća bila promicati neoliberalne ideje u SAD-u, Velikoj Britaniji, a i šire (Peck i Tickell 2002).

Kao što je već navedeno, početak širenja neoliberalnih ideja i neoliberalnih politika možemo smjestiti u prvu polovicu 1970-ih godina, kada je društveno politička konstelacija događaja bila takva da je funkcioniranje socijalne države koja je imala ulogu intervencije i redistribucije dobara sa svrhom ispravljanja negativnih učinaka djelovanja tržišta, postalo opterećeno problemima niske produktivnosti, porasta nezaposlenosti i pojave inflacije (MacLeavy 2016, Jessop 2016, Cahill 2014). Otad su uz neoliberalizam kao pojam tijekom vremena vezane raznovrsne konotacije, pa je tako 1970-ih pojam neoliberalizma bio vezan uz tržišno orijentiranu politiku u Latinskoj Americi, da bi napokon, od 1990-ih naovamo „neoliberalizam“ zadobio pejorativno značenje kojim se označava „niz ekonomskih institucija povezanih sa Sjedinjenim Američkim Državama i nastojanjem da se američki kapitalizam i američki kulturni sustav globaliziraju“ (Steger i Roy 2010).

\subsubsection{Osnovne značajke neoliberalne ideologije}

Rachel Turner (2008) pristupa neoliberalizmu kao ideologiji pri čemu kroz nekoliko koraka analize mapira konceptualnu konfiguraciju neoliberalizma. Turner (2008) određuje svoj 
znanstveni doprinos proučavanju povijesti ideja neoliberalizma pristupom koji nije kritički, a što smatra uobičajenom karakteristikom teoretizacija o neoliberalizmu i neoliberalnoj ideologiji kakve su primjerice opisane i u prethodnom tekstu. Cilj joj je opisati i analizirati strukturu ideologije neoliberalizma, ne zauzimajući nikakav vrijednosni stav prema samim neoliberalnim idejama, već sagledavajući političke prilike u vrijeme nastajanja neoliberalnih ideja, iz perspektive neoliberalnih teoretičara. Turner (2008) opisuje na koji su način neoliberalni mislioci, kao zastupnici jedne tendencije unutar liberalne tradicije, promatrali i promišljali o nastanku i razvoju kolektivističkih ideja u političko-ekonomskim okolnostima toga doba. Turner (2008) prvenstveno identificira središnje koncepte ključne za unutrašnju koherentnost neoliberalne ideologije, odnosno neoliberalnog identiteta. Smatra da su ključni koncepti neoliberalizma zapravo opći koncepti ili koncepti vezani uz sva liberalna usmjerenja, ali je korištenjem tih koncepata kao dijela političkog vokabulara interdiskurzivnim miješanjem, odnosno probijanjem diskurzivnih granica došlo do modifikacije njihova značenja. Povijesni razvoj konfiguracije neoliberalne ideologije predstavljao je formiranje neoliberalnog identiteta te premještanje naglasaka i značenja određenih koncepata. Neoliberalizam preuzima pojmove liberalizma kao intelektualnog pokreta te ih $\mathrm{u}$ skladu sa svojim političkim ciljevima prenamjenjuje čime im mijenja značenje te uspostavlja neku vrstu „hijerarhije“ koncepata koju je moguće shvatiti kao morfologiju neoliberalne ideologije. U tom se smislu neoliberalizam može definirati i kao struja liberalizma koja ima oblikovanu vlastitu morfologiju koncepata, pri čemu su neki liberalni koncepti smješteni u središte te morfologije, ili su hijerarhijski nadređeni, dok su drugi liberalni koncepti premješteni na periferiju.

Prema Rachel Turner (2008), kod neoliberalizma se termini doktrine i ideologije mogu koristiti bez velike diskriminacije u značenju, jer neoliberalna doktrina zapravo podrazumijeva preuzimanje pretpostavki i teorija iz područja klasičnog i neoklasičnog liberalizma te njihovo prilagođavanje s ciljem promicanja argumentacija koje se zalažu za slobodno samoregulirajuće tržište kao optimalan regulacijski mehanizam koji mora zamijeniti državnu regulaciju i državni intervencionizam kada je riječ o raspodjeli dobara u društvu. Sama neoliberalna doktrina koja opisuje načine na koji funkcioniraju ekonomija i tržište, stvara vlastita shvaćanja socijalne države, ali zapravo daje i jasne preporuke o tome što je u ekonomici poželjno, što je nepoželjno pa samim time signalizira i određene političke stavove. Turner (2008) u knjizi Neoliberalna ideologija obrazlaže nastanak i razvitak doktrine neoliberalizma, a kroz opis konfiguracije koncepata neoliberalizma, Turner, proučavajući neoliberalnu doktrinu i njezin postanak, nastoji ocrtati obrise neoliberalnog identiteta kao ideologije. 
Neoliberalizam kao varijanta liberalizma ima dodirnih točaka sa svim inačicama liberalizma te u mnogim aspektima predstavlja kontinuitet tradicije liberalne misli. Dio neoliberalnog identiteta čine središnji pojmovi liberalizma kao što su individualizam, sloboda te donekle i progres. Međutim, valja naglasiti da je neoliberalna misao sastavljena selektivnim odnošenjem njezinih autora prema tradiciji liberalizma, pa su se u svojim teoretiziranjima više oslanjali na klasični i neoklasični liberalizam, iako je i tu dolazilo do nekih diskrepancija i isključivanja određenih teza prisutnih u neoklasičnoj teoriji, kao što je na primjer klasični pristup koncepciji tržišta rada (Turner 2008, Jackson 2016). Koncept ljudskog kapitala povezan s pristupom u neoliberalnoj konceptualizaciji tržišta rada jedna je od rijetkih originalnih teorija u okviru neoliberalizma, a razvio ju je teoretičar Gary Becker, pripadnik Čikaške škole, dok je većina drugih elemenata neoliberalne doktrine zapravo nastala kroz prekrajanje i prilagodbu teza klasičnih liberalnih ekonomista, pa čak i elemenata kejnzijanske ekonomike (Foucault 2008, Palley 2005). Neoliberali su izmijenili strukturu liberalne ideologije, odnosno, rekonceptualizirali su je na način da su zadržali središnje pojmove liberalizma, a to su sloboda $\mathrm{i}$ individualizam, ali su im u određenoj mjeri promijenili značenje, a neke su koncepte koji su u okvirima liberalizma bili uglavnom periferni, odnosno marginalni koncepti, a to su vlasništvo i tržište, postavili kao „osovine“ koje podupiru čitav pojmovni aparat neoliberalne ideologije (Turner 2008).

Jedna od osnovnih teza knjige Rachel Turner (2008) jest ta da neoliberalna ideologija nije jedinstvena niti u potpunosti koherentna, već se sastoji od najmanje tri glavne struje neoliberalizma, od kojih je jedna od najznačajnijih njemački ordoliberalizam, čije su se ideje prve počele provoditi u organizaciji ekonomije i javnih politika u Njemačkoj već tijekom 1950ih godina, i to većinom zbog novonastale ideološke predanosti Njemačke nastojanju obuzdavanja inflacije, ali i kao protuteža moći države koja se smatrala tradicionalno sklonom zastranjivanjima u korupciju, protekcionizam i totalitarizam. Njemački se ordoliberalizam temeljio na liberalnim zamislima Immanuela Kanta i Wilhelma von Humboldta o pravnoj državi te je uvažavao neke opće vrijednosti neoliberalizma kao što su slobodni ugovori, privatno vlasništvo i otvoreno tržište; principe koje je kombinirao sa stvaranjem socijalno-tržišne ekonomije. Njemački je ordoliberalizam počivao na pretpostavci da natjecanje na slobodnom tržištu pruža bolju socijalnu zaštitu nego država koja je u Njemačkoj u to vrijeme bila nepopularna. Druge dvije struje neoliberalne doktrine su Austrijska škola kojoj pripadaju Ludwig von Mises i Friedrich Hayek, i Čikaška škola s najistaknutijim pripadnicima Miltonom Friedmanom i Garyjem Beckerom. Zamisli neoliberalne doktrine austrijske škole u 
mnogočemu se oslanjaju na ideje njemačkih ordoliberala, dok je sama Austrijska škola pak izvršila značajan utjecaj na razvoj čikaškog neoliberalizma. Identitet angloameričke varijante neoliberalizma velikim je dijelom utemeljen u teorijskim razmatranjima Friedricha Hayeka, dok Birch (2017) ističe da su djela Hayeka svojevrstan doktrinarni most između neoliberalizma čikaške škole s najznačajnijim predstavnikom Miltonom Friedmanom, i njemačke varijante neoliberalizma, odnosno ordoliberalizma. Navedene su tri škole, zapravo tri sekcije koje su utemeljile program neoliberalizma kroz djelovanje društva Mont Pelerin (Phelan 2014). Phelan (2014) tvrdi da su među sekcijama postojale značajne podjele te da je i sam Hayek priznao tijekom 1980-ih godina da je postojala mogućnost da se društvo Mont Pelerin raskoli na dvije struje: Friedmanovu i Hayekovu struju. Međutim, takav se scenarij nije obistinio iz razloga što su svi članovi Društva imali zajedničkog neprijatelja protiv kojeg su se borili, a to je bila socijalna država, odnosno kejnzijanski ekonomski režim državnog intervencionizma.

Ono što danas smatramo neoliberalnom ideologijom pretežno se identificira s učenjima ordoliberalizma, Friedricha Hayeka i Austrijske škole te Čikaške škole s Friedmanom i Beckerom kao glavnim predstavnicima. Ovim je sekcijama neoliberalne doktrine moguće dodati i neke doprinose manje utjecajnih pravaca kao što su Virdžinijska škola sa svojom teorijom javnog izbora, te Talijanska ili Bocconijeva škola sa svojom teorijom fiskalne konsolidacije koja je postala temeljem za do danas aktualne politike štednje. Rachel Turner (2008) opisuje razvitak, sadržaj, a djelomično i implikacije neoliberalne doktrine, odnosno ideologije, najvećim dijelom ju utemeljujući na analizi Hayekovih radova kao onoga što se može smatrati temeljem većine generičkih teza neoliberalizma.

Parafrazirajući Foucaulta (2008), raspravu o neoliberalnoj ideologiji i njezinoj diskurzivnoj artikulaciji valja započeti nekim banalnostima. Dakle, središnji pojam neoliberalne ideološke konfiguracije jest pojam (slobodnog) tržišta i tržišnog poretka. Prema neoliberalima, bez principa tržišnog upravljanja nema kapitalizma niti ekonomije koja funkcionira na racionalan i učinkovit način. Koncepti koji su u neoliberalnoj ideologiji združeni s konceptom tržišta i oko kojeg u diskurzivnoj artikulaciji neoliberalne doktrine gravitiraju, jesu: evolucija, spontani red, ograničeno znanje, individualizam i poduzetništvo (Turner 2008). U neoliberalnoj ideologiji slobodno tržište jedini je učinkoviti i racionalni način organiziranja ekonomije. Ekonomska organizacija utemeljena na principu tržišta kao regulacijskog mehanizma, po učinkovitosti uvelike nadilazi organizaciju na principu intervencije države, jer omogućuje najveći stupanj zadovoljstva za pojedince koji u njoj sudjeluju. Tržište, omogućujući slobodnu trgovinu i razmjenu, stvara zadovoljstvo svih uključenih aktera jer ih 
potiče na aktivnosti koje podrazumijevaju napredovanje i usavršavanje u područjima njihove „kompetitivne prednosti“ (Turner 2008). Država, kao sustav alokacije koji u neoliberalnoj ideologiji stoji u antagonističkom odnosu spram tržišta, opisana je kao korumpirana i neučinkovita. Neumjesna intervencija države u ekonomski sustav predstavlja prepreku u napredovanju nacionalnih ekonomija te stoga tu intervenciju valja ograničiti na uspostavljanje i održavanje uvjeta za optimalno, odnosno slobodno funkcioniranje tržišta koje se onda samostalno regulira.

Neoliberali imaju poseban opis i viziju tržišta, iako se njegove polazišne točke mogu naći u razvoju ideja i misli klasičnih ekonomista Adama Smitha, Davida Ricarda i Johna Stuarta Milla te neoklasičara kao što su Alfred Marshall, Carl Menger i Leon Walras. Neoliberalna koncepcija tržišta, uvelike utemeljena na Hayekovim radovima, odnosno na radovima članova Austrijske škole, ipak ima određene posebnosti koje ju izdvajaju iz teorijskih karakterizacija ostalih ekonomskih škola i usmjerenja.

„Osobito se djela Hayeka mogu smatrati dijelom šireg intelektualnog projekta preusmjeravanja društva natrag prema civiliziranom poretku liberalizma devetnaestog stoljeća i nadilaženja onoga što je on nazvao 'pretjerivanjima' klasičnog liberalizma, stvarajući bolje okruženje za djelovanje tržišta“ (Turner 2008: 121).

Tri su glavne teme Hayekova teoretiziranja o tržištu, a to su: spontani red, epistemička razmatranja, ekonomska efikasnost i ograničavanje djelovanja države.

Spontani red jedan je od ključnih koncepata pridruženih središnjem konceptu tržišta u okviru neoliberalne ideologije. Naime, spontani red ključan je za razumijevanje funkcioniranja slobodnog tržišta; funkcioniranja koje nije utemeljeno na racionalnom ljudskom djelovanju ili ljudskom razumijevanju njegovih mehanizama. „Tržišni poredak“, prema teoriji spontanog reda, proizvod je evolucije; to je spontano nastali red koji proizlazi iz aktivnosti pojedinaca koji nastoje ostvariti neke svoje individualne ciljeve. Koordinacija pojedinačnih djelovanja u kontekstu ekonomije slobodnog tržišta postiže se uz pomoć mehanizma oblikovanja cijena. Tržišni poredak je primjer spontanog poretka, koji Hayek naziva „katalaksijom“ od grčkog glagola katallattein koji označava ne samo „,razmjenu“ nego i „primanje u zajednicu“ i „,učiniti od neprijatelja prijateljem“ (Hayek 1998). U katalaksiji se razvoj odvija bez svjesnog planiranja i namjere, izrastajući iz spontanog djelovanja pojedinaca koji rade na postizanju vlastitih ciljeva. Hayek smatra da zbog navedenih svojstava i mogućnosti djelovanja tržišta, društva u 
kojima je tržište glavni mehanizam regulacije i raspodjele postižu najvišu razinu učinkovitosti. Ako bismo slijedeći Hayekovu doktrinu mogli zamisliti neko idealno društvo, onda bi se ono sastojalo od pojedinaca kao samozaposlenih poduzetnika i komercijalnih posrednika koji se natječu na tržištu. Uspjeh navedenih aktera, prema Hayeku, na slobodnom tržištu može ovisiti jedino o tržišnoj vrijednosti usluge ili proizvoda koje pojedinac nudi na tom tržištu. U tom smislu, uspjeh na tržištu ne ovisi o zaslugama, već uvelike o pukoj slučajnosti jer su na slobodnom tržištu sreća i peh raspodijeljeni potpuno ravnopravno i zato se ekonomska aktivnost ne može dovoditi u vezi s bilo kakvom vrstom moralnog obzira ili moralne odgovornosti koji bi obvezivao pojedinca. Utoliko je tržišni poredak superioran planiranoj ekonomiji koja ništa ne prepušta slučaju. Jedino što u prema Hayeku određuje ekonomski uspjeh jesu ,,pokretačke sile tržišnog natjecanja i dobro iskorištavanje individualne inicijative“ (Turner 2008: 124). Ekonomska efikasnost se ostvaruje mehanizmima sličnim prirodnoj selekciji u teoriji evolucije: oni koji nisu dovoljno kvalitetni i učinkoviti bivaju eliminirani, dok oni koji ostvaruju profit napreduju.

U neoliberalnoj ideologiji država ima ispunjavati specifičnu i važnu funkciju jer u suštini predstavlja važnu kariku u stvaranju neoliberalnog ekonomskog poretka, koji je utemeljen na redefiniranju uloge države. Država u neoliberalnoj doktrini, kako onoj u varijanti njemačkog ordoliberalizma, tako i u Hayekovoj, ima ulogu osigurati uvjete funkcioniranja ekonomskog poretka neoliberalnog karaktera. Ono što je za neoliberale važno, jest ograničiti djelovanje države odnosno odstraniti je iz bilo kakvog ekonomskog djelovanja koje bi se na neki način kosilo ili presijecalo s djelovanjem i ulogom koju su neoliberali namijenili tržištu. Međutim, kod Hayeka je postojala svijest o tome da sustav laissez-fairea ne može postojati bez jedne vrste intervencije države. Naime, država treba osigurati djelovanje institucija koje imaju ulogu potpore i zaštite individualizma i tržišta. Otvorenost društva mjeri se odnosnom države prema pojedincima te privatnom vlasništvu. Državi se, prema Hayeku, nikada ne smije dopustiti da podredi sebi društvo jer to dovodi do disfunkcije prethodno spomenutog spontanog reda, $\mathrm{i}$ „pretvara ga u totalitarni sustav u službi neke koalicije interesa“ (Turner 2008). Sumarno, za Hayeka se uloga države svodi na aktera koji jamči slobodu pojedinca, ali i koji može ispravljati određene nedostatke tržišta u slučajevima kada ono zakaže što upućuje na to da je bio svjestan činjenice da država ima važnu ulogu u potpori stvarnim tržištima. Državu u djelovanju valja ograničavati vladavina prava koja onda određuje ne toliko obujam državnih intervencija u ekonomsko djelovanje, već njihov karakter. Dakle, karakter državnog djelovanja mora biti kompatibilan s tržišnim imperativima te poštovati princip „,negativne slobode“. Država ima 
ulogu koordinacije, a pojedinci moraju biti slobodni djelovati u svom vlastitom ekonomskom interesu prema pravilima slobodnog tržišta. Država ne smije biti sredstvo provođenja sile nad djelatnošću pojedinaca, ali je Hayek smatrao da ona mora imati monopol na primjenu sile kako bi onemogućila privatne osobe da ograničavaju slobodu drugih pojedinaca. Država također može provoditi određene politike koje se tiču javnog zdravlja i sigurnosti, pružati određene javne usluge koje se financiraju iz poreza, osigurati određenu razinu obrazovanja stanovništva te pružati minimalnu socijalnu zaštitu za one koji nisu zapošljivi (Turner 2008: 126, Hayek 2011).

Opće je mjesto da tržišta imaju mnoge nedostatke koji bacaju sumnju na to da su ona sposobna bez intervencije države sama izregulirati svoja potencijalna zatajenja. Iako predani idealu funkcionalnog samoregulacijskog tržišta, neoliberali međutim i sami priznaju da slobodna tržišta imaju određene „nesavršenosti“ koje su neizbježne za tržišni poredak, i koje predstavljaju opasnost za održivost tržišnog poretka. Te nesavršenosti su monopol, regulacija i birokracija. Monopol se u neoliberalnoj doktrini smatra normalnom aberacijom koja ne mora nužno ukazivati na to da natjecanje na tržištu u nekom fundamentalnom smislu ne funkcionira, već jednostavno pojavom koja privremeno potkopava tržišno natjecanje. Međutim, neoliberali također prave distinkciju između dvije vrste monopola, od kojih jedna ima negativnije konotacije u smislu destruktivnosti za konkurentnost od druge. Hayek je prema toj premisi podijelio monopole na monopole poduzeća i monopole rada. Smatrao je da monopoli poduzeća ne predstavljaju veliku opasnost za funkcioniranje tržišne ekonomije jer su oni zapravo posljedica toga što se neki subjekti na tržištu usavršavaju i unaprjeđuju svoju ponudu roba ili usluga. S vremenom monopoli poduzeća gube svoju prednost jer ih konkurenti dostižu u kvaliteti ili specifičnosti ponude. Monopoli poduzeća mogu imati negativne posljedice u slučaju kada nastoje zadržati svoju monopolsku poziciju tjerajući neke tvrtke ili pojedince na ponašanje i djelovanje protiv njihove volje ili sprječavajući im pristup tržištu. U tim slučajevima, Hayek je smatrao da treba intervenirati država tjerajući tvrtke da prihvate gubitak monopola pridržavajući se određenih pravila ponašanja koje sprječavaju zadržavanje monopolske pozicije nakon prestanka objektivnih uvjeta koji čine mogućom njihovu superiornu izvedbu na tržištu. Na pitanju monopola poduzeća se razilaze Austrijska, odnosno ordoliberalna i kasna Čikaška škola neoliberalizma, s obzirom na to da potonja smatra da nije potrebna državna intervencija kada je riječ o onemogućavanju korporativnih monopola na tržištu, jer su poduzeća i tržište dio jednog te istog kontinuuma, monopoli nisu toliko česti na tržištima koliko se čine te da ukoliko i nastanu imaju tendenciju da se razriješe spontano i bez intervencije države (Birch 2017). 
Ono što prema neoliberalima vrijedi za monopole poduzeća, ne vrijedi i za monopole rada, pa možemo reći da neoliberalni antagonistički stav prema sindikatima potječe od navedene, pa čak i ideološki motivirane distinkcije. Pri osudi monopola rada, Hayek ističe da oni nisu proizvod usavršavanja izvedbe aktera na tržištu, odnosno radnika, već da je monopol rada posljedica „,nasilnog potiskivanja natjecanja na tržištu“ te da su „monopoli rada veća prijetnja funkcioniranju konkurentnih tržišnih uvjeta, a time i značajna prijetnja slobodi kao takvoj“" (Turner 2008: 127).

Drugi problem koji neoliberali vide kod djelovanja tržišta jest njihova potreba za nekim oblikom birokracije koja bi imala ulogu regulacije i kontrole univerzalnog provođenja pravila pravednog ponašanja. Bez navedene regulacije u skladu s univerzalnim pravilima tržišta ne mogu postojati. Univerzalna pravila koja se provode radi funkcioniranja tržišta odnose se na oblik apstraktnih pravila čiji je cilj očuvanje ,života, slobode, i imovine“, dok se u ta univerzalna pravila ne ubrajaju „socijalna pravda“ ili ,javno pravo“ za koje je Hayek smatrao da podčinjavaju pojedince nekom obliku autoriteta (Turner 2008: 128). Nedostatak birokracije, odnosno administrativnih agencija koje nastaju kao potpora tržištu, je njihova sklonost da iz regulacijskih agencija koje provode pravila pravednog ponašanja, prijeđu u administrativna tijela koja karakterizira organizacijski oblik razmišljanja i nastojanje da gospodare pojedincima, da ih „obrazuju“ racionalnosti kroz neki oblik jednosmjernog javnog uvjeravanja. Uloga regulacije kod osiguravanja slobode tržišta također je primjer pitanja oko kojeg se i sami neoliberali razilaze. Neki mislioci smatraju da regulacijske agencije usavršavaju djelovanje tržišta provodeći pravila pravednog ponašanja čime štite privatno vlasništvo i osiguravaju provođenje pravila i zakona, dok postoje neoliberali, kao na primjer Norman Barry, koji obaveznu državnu regulacija smatraju nepotrebnom (Turner 2008). Prema Barryju sva regulacija može biti prepuštena tržištu jer su tržišta oduvijek bila nesavršena, a njihovi se nedostaci također oduvijek rješavaju spontano kroz podešavanje cijena dok se ne postigne optimalno funkcioniranje. Za njega je sustav državne regulacije ovakvog oblika neučinkovit i narušava konkurentnost na tržištu. Većina neoliberalnih teoretičara smatra da je minimalni i precizno određeni oblik državne intervencije koji mora biti koncentriran isključivo u političkoj sferi djelovanja, potreban kako bi se ispravljale nesavršenosti stvarno postojećih tržišta, kako ta zatajenja ne bi zaprijetila stabilnosti društvenih institucija koje između ostalog igraju važnu ulogu u održavanju kapitalističkog poretka.

Turner (2008) govori kako je tržište središnji koncept neoliberalnog diskursa nacionalnih kapitalističkih ekonomija, koji je posebno naglašen u anglosaksonskom obliku 
kapitalizma kao modela koji najbolje predstavlja primat tržišta u funkcioniranju ekonomije. Navedeni anglosaksonski model, odnosno neoamerički ili atlantski model kapitalizma počiva na „tržišnom poticanju individualnog uspjeha i kratkoročne financijske dobiti“ (Turner 2008: 130). Središnje mjesto u ovom modelu, za razliku od ordoliberalnog, zauzima privatna kompanija, a ne država. Centralna premisa anglosaksonskog modela neoliberalnog kapitalizma je da poduzeće mora biti slobodno djelovati u svrhu kratkoročnih ciljeva ostvarivanja profita s ciljem „stvaranja kapitala na otvorenim financijskim tržištima“ (Turner 2008: 130). Ono što je karakteristično za anglosaksonski model neoliberalizma jest da upravo zbog imperativa stvaranja uvjeta za što veću slobodu poduzeća, tržišta rada postaju sve manje regulirana, odnosno gotovo neregulirana, pa su radnici prepušteni samo vrlo osnovnim zaštitama zajamčenim zakonima.

Neoliberalni se modeli razlikuju od države do države, osobito u načinima na koje su shvaćane uloge države i tržišta te modelima prema kojima je postavljeno njihovo međudjelovanje. Pa tako Foucault (2008), na primjer, navodi kako je, kada se radi o prihvaćanju neoliberalizma u Europi, a pogotovo u Njemačkoj, uvijek bila naglašena uloga tržišta u obuzdavanju države koja je bila tradicionalno povezana s raširenom korupcijom. Iz tog se razloga, a i zbog negativnih iskustava sa socijalizmom, Njemačka okrenula tržištu ne bi li regulirala industrijsku modernizaciju i strukturalne promjene. U Britaniji je neoliberalni program bio prihvaćen kao pokušaj da se obnovi razdoblje slobodne trgovine devetnaestog stoljeća, a u Sjedinjenim Američkim Državama neoliberalizam je prihvaćen zbog kompatibilnosti s vrijednostima slobode kao državotvornim vrijednostima te je neoliberalna organizacija ekonomije shvaćena kao model koji omogućuje obranu upravo tih vrijednosti.

U mreži koncepata koji čine neoliberalnu ideologija, Turner (2008) navodi jedan periferni koncept koji je posebno vezan za anglosaksonske modele neoliberalnih ekonomija, a to je poduzetničko društvo. Pojam poduzetničkog društva predstavlja za neoliberale ključni koncept za razlikovanje između oblasti ekonomije i politike. Ekonomija u neoliberalnom kontekstu evocira pojmove kao što su samoregulirajuće tržište i kultura poduzetništva, dok je politika povezana s pojmovima aktivne države, korporativizma i kulture zavisnosti. Duh poduzetništva činio je važan dio neoliberalnih politika tijekom vladavina Margaret Thatcher i Ronalda Reagana, kada se ohrabrivala individualna inicijativa oslobođena od birokratskih prepreka oslanjanjem na slobodno tržište. Stvaranje kulture poduzetništva koja je stavljala težište na kratkoročne rezultate utemeljene na djelovanjima i odlukama pojedinačnih poduzetnika, bez birokratske regulacije, nalazila je svoj temelj u već spomenutim naglascima 
Hayekove doktrine na aktivnosti, poduzetnosti i inicijativi pojedinaca koji su se ponašali u skladu s vlastitim slobodno donesenim odlukama, na čemu se uostalom i temelji cjelokupni ekonomski napredak. Tu je nastao i profil neoliberalnog ideala poduzetnika kojega krase vrline poput hrabrosti i samodostatnosti. Dakako, tržište se smatra arenom u kojoj postoje gubitnici i pobjednici, međutim ishodi borbi na tržištu su nepredvidljivi, a podjela poduzetnika na gubitnike i pobjednike spada u prirodne učinke djelovanja tržišnih odnosa. Konkurencija je smatrana sredstvom kojim se ekonomija pročišćava od neučinkovitih kompanija, a resursi se dalje raspodjeljuju prema tržišnim principima za dobrobit cijele zajednice. Uspostavljanje navedene poduzetničke kulture u raznim je nacionalnim kontekstima zahtijevalo promjene $\mathrm{u}$ osmišljavanju i provedbi ekonomskih i socijalnih politika, pa je tako uspostavljanje ekonomije slobodnog tržišta podrazumijevalo politike koje decentraliziraju državu. Privatizacija je bila najvažnija politika uklopljena u kontekst uspostave takozvanog poduzetničkog društva, kada je poduzetništvo bilo središte oko kojega su se oblikovale javne politike u Britaniji i SAD-u tijekom 1980-ih godina. Državno vlasništvo velikih kompanija bilo je neprihvatljivo neoliberalima i gotovo u potpunosti nekompatibilno s osnovnim postavkama neoliberalnih teorija koje čine korpus neoliberalne doktrine. Neoliberali su se zalagali za privatizaciju državnih poduzeća jer su smatrali da je potrebno izložiti zaštićenu industriju koja je poslovala pod patronatom države konkurenciji na tržištu čime bi se povećala kvaliteta proizvodnje i usluga te povisile stope profita, a istovremeno bi se uloga alokacije resursa premjestila s države na tržište. Privatizacija, prema neoliberalnim pretpostavkama, ima velike prednosti nad državnim vlasništvom, a to su: smanjenje veličine i opsega državne kontrole, povećanje individualnih sloboda ekspanzijom izbora potrošača, smanjenje potrebe za javnim zaduživanjem, smanjenje sudjelovanja vlade u industrijskim neslaganjima, osiguranje učinkovitosti industrije zbog izloženosti pritiscima dioničara, smanjenje utjecaja interesnih skupina na donošenje odluka o investicijama, ohrabrivanje poduzetničkog društva i ekonomskog uspjeha povećanjem udjela vlasništva dionica među populacijom, smanjivanje snage sindikata te općeniti blagotvorni utjecaj na ostatak ekonomije (Turner 2008: 131). Vođeni ovim nastojanjima oko stvaranja poduzetničkog društva, Margaret Thatcher i Ronald Reagan poduzeli su mnoge privatizacije velikih kompanija i državne imovine, međutim ispostavilo se da privatizacija nije imala one učinke koji su bili predviđeni u smjeru povećanja učinkovitosti i jačanja uloge tržišta u raspodjeli resursa jer su javni monopoli jednostavno bili zamijenjeni privatnim monopolima (Larner 2000, Birch 2017). Osim privatizacije državnih kompanija, u Britaniji i SAD-u također se provodila privatizacija javnih usluga obrazovanja i zdravstva također pod pretpostavkom da će se na taj način smanjiti zaduživanje države što će pomoći 
smanjiti inflaciju, zatim smanjiti porezno opterećenje te s obzirom na to da će se smanjiti obujam socijalnih usluga oslobodit će se prostor za širenje tržišta. Birch (2017) ukazuje na empirijska istraživanja u Velikoj Britaniji koja pobijaju ovu tezu, koju podupiru i zagovaratelji privatizacije, ali i kritičari, pretpostavljajući jedne te iste učinke ali s negativnim predznakom. Naime, istraživanja su pokazala da su se iznosi koje je država izdvajala za javne i socijalne usluge stabilno povećavali od vladavine Margaret Thatcher naovamo.

Turner (2008) navodi da je središnji i najvažniji pojam koji je nositelj cjelokupne neoliberalne ideologije tržište, čiji se opis u neoliberalnoj doktrini nastavlja na konceptualizaciju tržišta klasičnog liberalizma, zasnovanom na djelovanju pojedinaca koji nastoje ostvariti ekonomski interes, nadovezujući se na radove Mandevilla i Smitha. Uz tržište se nadovezuju neki sekundarni, odnosno periferni koncepti koji tvore pojmovni aparat neoliberalne ideologije i diskursa, a to su poduzetnička kultura, olakšice poreza na dohodak, privatizacija, deregulacija i dioničarstvo.

\subsubsection{Fluidnost neoliberalnog identiteta}

S obzirom na povijesne okolnosti u kojima je nastao, neoliberalizam je svoj doktrinarni, ideološki identitet oblikovao ponajviše u relaciji s identitetom socijalne države i politikama socijalne zaštite. Kako je ranije već spomenuto, neoliberalna se doktrina razvijala kao nastojanje obnove ekonomskog režima u čijem je središtu tržište, a ne država kao što je to bio slučaj tijekom nekoliko desetljeća nakon drugog svjetskog rata. Naime, nakon velike gospodarske krize koja je ukazala na nedostatke i kritične točke lessaize-faire ekonomije te bijede drugog svjetskog rata i velikih ljudskih žrtava, socijalna je država za tadašnje prilike bila logična reakcija na društvene, ekonomske i političke uvjete. Međutim, u nekim su ekonomskim krugovima postojali teoretičari koji se nisu slagali sa smjerom tadašnjih ekonomskih politika i koji su u sjeni kejnzijanske ekonomike osmišljavali drugačiji ekonomski program politika utemeljen na doktrini koja je nastala upravo kao kritika i reakcija na tadašnje dominantne stavove o strukturi ekonomskog režima te ponajprije o ulozi države u ekonomiji. Phelan (2007a, 2014) i Turner (2008) ukazuju na to da je neoliberalni diskurs uvelike omeđen konceptima vezanima uz socijalnu državu, osobito za neoliberalno viđenje socijalne države. Pri određivanju karakteristika neoliberalne ideologije treba uvažiti i neoliberalnu percepciju socijalne države kao „,značajnog Drugog“ prema kojem se definira mreža koncepata neoliberalnog diskursa. Dakle, neoliberalni su mislioci definirali svoj ekonomski program uvelike u odnošenju s 
programom kejnzijanske ekonomike, u odnosu na koji je neoliberalizam odgovor na nedostatke koje su identificirali u okviru politike državnog intervencionizma (Tablica 3.1).

Veliki dio neoliberalnog diskursa predstavljaju koncepti povezani s principima kejnzijanske socijalne države. Ovdje je riječ dakako o socijalnoj državi i s njome povezanim skupom politika te mreži pojmova kojom se oni označuju, koji su koncipirani kroz diskurzivni repertoar artikulacije neoliberalne ideologije. Koncept socijalne zaštite (eng. welfare), težište je oko kojega se oblikuje neoliberalni diskurs o socijalnoj državi. Na pojam socijalne zaštite nadovezuju se drugi ključni pojmovi neoliberalnog diskursa poput minimalne države, jednakosti prilika, negativnih prava, samodostatnosti i osobne odgovornosti. Kroz navedene pojmove neoliberalni diskurs se učvršćuje i operacionalizira te je pomoću njih konstruirana neoliberalna hijerarhija vrijednosti i ciljeva djelovanja. Središnje pitanje neoliberalnog razmišljanja jest kako osigurati dobrobit ljudi u kontekstu socijalne zaštite i je li pitanje socijalne zaštite moguće riješiti državnim intervencionizmom. Kada neoliberali razmišljaju o pitanju ,uplitanja“ države u socijalno osiguranje, oni to vide u terminima etike i efikasnosti te o njemu raspravljaju prema neliberalno ideološkom relacijama antagonizma države i tržišta te privatnog i javnog. Neoliberalni stav prema socijalnoj državi fundamentalno je negativan, jer u neoliberalnoj viziji društva tržište je suprotstavljeno državi, a privatno je suprotstavljeno javnome. U kontekstu neoliberalnog diskursa, socijalna pomoć ima pejorativno značenje jer neoliberalni mislioci smatraju da socijalna zaštita iskrivljuje i asimilira koncepte koje neoliberali vole vezivati uz vlastitu koncepciju tržišta, a to su individualna prava i pravda.

Phelan (2014) ukazuje na potrebu za uvažavanjem jednog šireg, ali istovremeno konkretnijeg shvaćanja neoliberalizma od identiteta iskazanog isključivo kroz ideološki motivirano i tvrdolinijaško suprotstavljanje principa tržišta principu države kada se radi o ekonomskom, ali i širem kontekstu djelovanja te isticanje superiornosti tržišta kao modusa ekonomske organizacije. Kod identificiranja artikulacije neoliberalnih ideologija, odnosno kod identifikacije neoliberalnog diskursa, čest je slučaj da se ono što se označuje kao neoliberalno, poistovjećuje s tvrdom pozicijom ideološki motiviranih zagovaratelja neoliberalizma, čemu je zorni primjer diskurs koje se povezuje s Margaret Thatcher, ili s ciljanim zagovaranjem politika konstruiranih od transnacionalnih organizacija poput Svjetske banke, Svjetske trgovinske organizacije ili Međunarodnog monetarnog fonda. Phelan (2014) ukazuje na to da se tako uskim i reduciranim shvaćanjem neoliberalizma dolazi do propuštanja identificiranja neoliberalne ideologije artikulirane kroz diskurs koji prati u osnovi neoliberalni karakter određenih nacionalnih politika, bilo kao odraz provođenja neoliberalnih politika, ili kao sredstvo 
konstituiranja političkog, a to znači uspostavu i održavanje hegemonijskog poretka radi olakšavanja provođenja neoliberalnih politika.

U analizi irskog tiska, Phelan identificira dva tipa neoliberalnog diskursa koje naziva „transparentnim“ neoliberalnim diskursom, i „eufemiziranim“ neoliberalnim diskursom, kao dvama distinktivnima „oblicima retoričke i političke identifikacije s neoliberalizmom“ (Phelan 2007b). Phelanovo dvojako shvaćanje neoliberalizma korisno je u analizi diskurzivnih praksi jer omogućuje bolje razumijevanje ,političke aproprijacije neoliberalnih pretpostavki“ $s$ obzirom na to da nema mnogo političara u Europi koji smatraju da bi artikulacija transparentnog neoliberalizma u javnom diskursu mogla biti korisna za ostvarenje političkih ciljeva, odnosno za provođenje neoliberalnih politika (Phelan 2007b: 32).

Transparentni se neoliberalizam odnosi na doktrinu koju su oblikovali prvenstveno Friedrich Hayek i Milton Friedman, kao neoliberalni identitet najjasnije artikuliran kod nastupa Margaret Thatcher, s nedvosmislenim ideološkom naglascima; konfrontacijski i jasno iznesenim neoliberalnim programom. Neoliberalni je identitet $\mathrm{u}$ transparentnoj varijanti konstituiran kroz kontrastiranje i antagonizam prema principima i djelovanju kejnzijanske intervencionističke socijalne države (Tablica 3.2). Transparentni je identitet neoliberalizma iznesen u tablici utemeljen na neoliberalnoj doktrini koju su opisali i popularizirali neoliberalni mislioci, a među najznačajnijim su tekstovima Put u ropstvo i Ustrojstvo slobode, Friedricha Hayeka te Kapitalizam i sloboda Miltona Friedmana. Phelan pojašnjava svaku od binarnih opozicija koja konstituiraju neoliberalni identitet kroz artikulaciju identiteta socijalne države kao njegove suprotnosti. Sloboda se unutar neoliberalnog diskursa može shvatiti kao prazni označitelj, koji preuzima ulogu hegemonijskog povezivanja preostalih navedenih elemenata neoliberalnog identiteta. „Neoliberalna“ negativna sloboda artikulirana je kao odnos ljudi s drugim ljudima te jedini oblik uskraćivanja te vrste slobode jest kroz prisilu koju provode ljudi nad ljudima. Negativna sloboda se u potpunosti razlikuje od pozitivne slobode. Nadovezujući se na koncept negativne slobode, tržište u neoliberalnoj ideologiji označava područje ekonomske slobode. Državu, kao suprotnost tržištu, obilježava iluzorna politička sloboda koja je fundamentalno prisilnog karaktera. Neoliberalna doktrina daje primat individui, dok su pojmovi povezani s kolektivnom, kao što su društveno ili javno dobro, nešto što se u najboljem slučaju može promatrati sa sumnjom. Tržište služi postizanju ciljeva pojedinaca te je iz tog razloga vrjednije od države koja je shvaćena kao instrument širenja lažnih predodžbi o mogućnostima društvenih, to jest kolektivnih ciljeva. Phelan (2007b) kaže da je neoliberalni identitet s razlogom retorički izjednačen s identitetom običnog čovjeka ne bi li se zatomila 
implikacija da oni koji zapravo najviše dobivaju širenjem tržišnih sloboda jesu elite. Država se u transparentnoj diskurzivnoj formaciji neoliberalizma povezuje s elitizmom „sveznajućeg“ intelektualca.

Tablica 3.1 Politički identitet neoliberalizma: ključne binarne opozicije

Neoliberalizam

Kejnzijansko/kvazisocijalističko Drugo

Negativna sloboda/sloboda od

Ekonomska sloboda

Tržište

Pojedinac

Sredstva

Običan čovjek
Pozitivna sloboda/sloboda za

Politička sloboda

Država

Kolektiv

Ciljevi

Intelektualac

Tablica 3.1 prema Phelanu (2007b).

Prikaz relacija koje čine neoliberalni identitet u terminima jasno iskazanog antagonizma prema državi, Phelan smatra (2007b) previše ideološki transparentnom pozicijom koja u javnom političkom diskursu ima malu performativnu vrijednost. Iz tog razloga, pri analizi neoliberalne hegemonije u diskurzivnim praksama, ustanovljene relacije karakteristične za neoliberalni diskurs valjda nadopuniti analizom artikulacija neoliberalizma povezanih $\mathrm{s}$ nastojanjima da se spomenuta ideološka pozicija ublaži. Navedene blaže artikulacije neoliberalnog diskursa, Phelan (2007b) naziva eufemiziranim neoliberalnim diskursom. Eufemizirani diskurs teži izbjeći iskazivanje otvorene, ideološke neoliberalne pozicije, a svojstveno mu je korištenje termina kao što su „partnerstvo“, „,moderno“, „,nacionalna dobrobit“ i slično. Eufemizirani neoliberalni diskurs preuzima ono što smatra „zdravorazumskim“ postulatima transparentnog neoliberalnog diskursa, ali se iz pragmatičnih razloga nastoji riješiti iskaza u obliku otvorenih antagonizama prema društvenom, kolektivnom, državnom i javnom, utvarajući si jednu neideološku poziciju. Phelan (2007b) smatra da ga upravo poziranje dezidoeologiziranosti čini i više ideološkim od transparentnog diskursa jer pomirujući državu i tržište, eufemizirani neoliberalni diskurs naturalizira neke opće neoliberalne pretpostavke te na 
taj način zaobilazi kritiku i neutralizira potencijalno oponiranje alternativnih diskursa. Pomirljiviji karakter eufemiziranog neoliberalnog diskursa uspješnije eliminira diskurse koji mu se suprotstavljaju jer s obzirom na to da je umjereniji u svojoj artikulaciji, on umjerenu i uvjetno rečeno razumnu kritiku lako apsorbira u sferu konsenzusa s neoliberalnim predznakom, dok se diskursi čija se kritika temelji na postavkama koje su prerazličite da bi s njima pronašao dodirne točke kao temelj za asimilaciju, lako označava ekstremnima čime ih bez prevelikih poteškoća eliminira iz ozbiljnijih rasprava, bili oni označeni kao „fundamentalistički“, „tradicionalni““ ili „,iracionalni“. Za identitet eufemiziranog neoliberalnog diskursa, osim nastojanja da se eliminira identifikacija s otvoreno neoliberalnim karakteristikama koje isključuju kompromis s državom, ne bi li se izbjegla etiketa ideološkog, važne su i druge karakteristike kojima se nastoji distancirati od onog što je transparentno neoliberalno, pa tako previše izloženo kritici (Tablica 3.2).

Za potrebe naše analize od značaja je u kratkim crtama opisati nalaze Phelanove (2007b, 2014) analize medijatiziranog političko-ekonomskog diskursa u Irskoj, u kojoj on prema navedenim propozicijama transparentnog i eufemiziranog neoliberalnog diskursa identificira ključne retoričke strategije koje strukturiraju neoliberalni diskurs političke elite ukazujući na prevladavanje neoliberalnih pretpostavki u javnom diskursu.

Tablica 3.2 Heuristička usporedba eufemiziranog i transparentnog neoliberalizma

\begin{tabular}{ll}
\hline Eufemizirani neoliberalizam & Transparentni neoliberalizam \\
\hline Postideologija & Ideologija \\
Praksa i zdrav razum & Teorijska svijest \\
Partnerstvo & Antidržavno \\
Pragmatično & Protržišno \\
Socijalna zaštita/nacionalna dobrobit & Individualna sloboda \\
Progresivno i moderno & Evangeličko i arhaično \\
\hline
\end{tabular}

Tablica 3.2 prema Phelanu (2007b).

Upravo je socijalno partnerstvo retorička strategija koju Phelan (2007b) identificira kao prazni označitelj eufemiziranog diskursa u javnom i medijskom prostoru. Naglašavanjem 
socijalnog partnerstva, politički akteri koriste pozitivnu neutralnost tog pojma kao strategiju neutraliziranja moguće identifikacije temeljno neoliberalnih stajališta kao ideoloških, i to neutralizacijom konfliktnih razmjena s akterima koji u određenim političkim domenama ili politikama ne dijele iste stavove i interese. Socijalno partnerstvo se također može shvatiti kao kompromisna strategija spajanja neoliberalnih politika sa socijalnim programima, koji su instrumentalizirani kao svojevrsno pokriće koje neutralizira kritiku o socijalnoj neosjetljivosti i interesnoj motiviranosti neoliberalnih politika koje su u interesu odabranih poslovnih krugova. Za retoričku je strategiju socijalnog partnerstva tako karakteristično korištenje zamjenice „mi“ u značenju sviju zajedno, čemu političari pribjegavaju kako bi naglasili ujedinjenost s publikom i dijeljenje sudbine s narodom kojem pripadaju. Karakteristično je i kombiniranje neoliberalnih naglasaka na potrebu postizanja konkurentnosti i to kroz sasvim određene (neoliberalne) politike poput liberalizacije tržišta, deregulacije, i privatizacije s umjerenijim označiteljima preuzetima iz egalitarnih i zajedničarskih diskursa te diskursa održivosti.

Još jedna retorička strategija karakteristična za eufemizirani neoliberalni diskurs jest neutraliziranje diskursa kritike aproprijacijom fragmenata tih istih diskursa. Phelan (2007b) ukazuje na to da eufemizirani neoliberalni diskurs često bude artikuliran kao interdiskurzivna formacija koja sadrži elemente diskursa koji su zapravo artikulacija kritike i suprotstavljanja neoliberalizmu. Asimilacija elemenata kritike neoliberalizma i njegovih postulata ne umanjuje legitimirajući karakter eufemiziranog diskursa. Uključivanjem kritičkih elemenata, izbjegava se mogućnost pripisivanja ideološke pozicije „glasu“ diskursa, odnosno nekom društvenom akteru. Unatoč tome što interdiskurzivna formacija eufemiziranog neoliberalnog diskursa može sadržavati i kritiku neoliberalnih politika, ugrađivanje kritičkih diskursa služi samo za ublažavanje onog za što se može reći da je ujedno nedvosmisleno neoliberalno i oko čega nema kompromisa, odnosno ono što je u toj interdiskurzivnoj konstrukciji zadano kao neupitno.

Bastiaan Van Apeldoorn (2009) također analizira neoliberalni diskurs u kontekstu diskursa Europske unije u dokumentu Lisabonske strategije te pronalazi elemente interdiskurzivnosti koju je moguće okarakterizirati kao skup retoričkih strategija koji se može usporediti s Phelanovim (2007b, 2014) eufemiziranim neoliberalnim diskursom. U Apeldoornovoj analizi se radi o interdiskurzivnoj formaciji diskursa Europske unije koji se sastoji od diskursa neomerkantilizma, neoliberalnog diskursa i socijalno demokratskog diskursa, pri čemu je neoliberalni diskurs identificiran kao hegemonijski, odnosno dominantni diskurs u diskursu Europske unije artikuliranom u Lisabonskoj strategiji. Van Apeldoorn, kao i Cahill, pripadaju teoretičarima koji neoliberalizam analiziraju iz marksističke perspektive 
klasnih sukoba u kombinaciji s teoretizacijama Karla Polanyja i njegovog pojma uklopljenosti, pa za njih cjelokupni neoliberalni projekt nije pokrenut kao rezultat primjene neoliberalne ideologije (proizašle iz neoliberalne doktrine) na kreiranje i provođenje politika s neoliberalnim predznakom, već neoliberalna ideologija predstavlja sredstvo legitimacije neoliberalnih politika čime se olakšava njihovo provođenje u svrhu dominacije kapitalističke klase.

Van Apeldoorn (2009) iz perspektive političke ekonomije pristupa procesu širenja neoliberalnih politika u Europskoj uniji pri čemu razlikuje europski (kontinentalni) neoliberalizam od anglosaksonskog tipa neoliberalizma. Obrazlažući nastanak takozvanog uklopljenog neoliberalizma u Europskoj uniji kao transnacionalnog hegemonijskog projekta, van Apeldoorn (2009) locira ishodišta njegova nastanka u dvije krize europskog kapitalizma i europskog transnacionalnog projekta. Osobito je bila ključna kriza koja se odvijala tijekom ranih 80-ih godina 20. stoljeća. Kao pokušaj odgovora na tu krizu, nastala su tri različita i suparnička projekta koji su zastupali različite interese, ali sve u pokušaju da se riješi tadašnja kriza europskog transnacionalnog projekta. Rješenje krize sva su tri projekta nalazila u dovršetku uspostavljanja zajedničkog unutarnjeg tržišta. Ono po čemu su se razlikovali bila je vrsta tržišta koju se predlagali, pa tako u skladu s vizijom tog unutrašnjeg tržišta imamo neomerkantilističku koncepciju, neoliberalni projekt te socijalno demokratski projekt. U okviru neomerkantilističke koncepcije europsko je tržište zamišljeno prvenstveno kao jedno veliko domaće tržište koje bi po potrebi bilo zaštićeno carinama, čime bi industrijskim akterima bilo omogućeno da konkuriraju američkoj i japanskoj industriji. Neoliberalni je projekt promicao otvaranje europskog tržišta globalnoj ekonomiji naglasivši potrebu da uspostavljeno unutarnje tržište bude što slobodnije. Socijalno demokratski projekt nadao se učvrstiti „europski socijalni model“" uokvirivanjem propisa kroz uspostavu nadnacionalne regulacije (van Apeldoorn 2009: 23). Van Apeldoorn (2009) tvrdi da je u nadmetanju interesa između navedenih vrsta projekata, prevladala i hegemonijski zavladala neoliberalna koncepcija. Međutim, neoliberalni projekt koji je zavladao imao je i neke specifične karakteristike koje ga razlikuju od ortodoksnog neoliberalizma karakterističnog za anglosaksonsko gospodarsko okruženje. Te su razlike osobito prominentne u kontekstu njegove ideološke dimenzije, pri čemu je njegov diskurs, odnosno diskurs takozvanog europskog kontinentalnog neoliberalizma nastao srastanjem $\mathrm{s}$ moderniziranim socijalno demokratskim diskursom. Time je zadovoljena i potreba određenog dijela europskih kapitalista koji su smatrali da bi mogli profitirati od povremene, aktivnije uloge države u kreiranju politika. Van Apeldoorn (2009) pojašnjava kako je neoliberalni projekt uspostavio hegemoniju u Europskoj uniji kroz asimilaciju elemenata suparničkih vizija ostvarenja zajedničkog europskog tržišta. Na taj je način europski kontinentalni neoliberalizam 
neutralizirao potencijal opasnosti koju su predstavljali ovi alternativni pogledi na funkcioniranje tržišta i države, čime je otvorio prostor za nesmetano dirigiranje javnim politikama prema suštinski neoliberalnim interesima, odnosno interesima kapitalističke klase.

Ovu je kombinaciju interesa, politika i ideologija, van Apeldoorn (2009) nazvao „uklopljenim neoliberalizmom“ jer iako navedeni ekonomski režim sadrži elemente i neomerkantilizma i socijalne demokracije, ciljevi ovih dvaju modela uvijek su podređeni provođenju neoliberalnih politika koje osiguravaju slobodno tržište i slobodno poduzetništvo. „Uklopljeni neoliberalizam“ se sastoji od dvije komponente koje su naizgled nespojive. Pojam „uklopljenosti“ preuzet je od Polanyjeva opisa uloge države koja svojim djelovanjem s jedne strane omogućuje djelovanje tržišta, ali i štiti samo društvo od destruktivnih posljedica kojima tržište prijeti u uvjetima u kojima nije na odgovarajući način regulirano. Takva se kombinacija države i tržišta naziva ,principom socijalne zaštite“. Na suprotnoj strani imamo nastojanja oko uspostave samoregulirajućeg tržišta što je „princip ekonomskog liberalizma“. Van Apeldoorn (2009) nastoji pokazati, na temelju diskurzivne analize Lisabonske strategije, da uklopljeni neoliberalizam, iako kombinira dva suprotna principa ekonomskog djelovanja, u osnovi privilegira princip ekonomskog liberalizma, podređujući mu socijalnu zaštitu u svim bitnijim pitanjima. Kontinentalnom europskom neoliberalizmu svojstvena je karakteristična predanost slobodnom tržištu i vrijednosti privatnog vlasništva, međutim zbog ukorijenjenosti tradicije industrijskih odnosa i socijalne zaštite koju pruža država, ta je varijanta neoliberalizma u sebe uklopila navedene institucije tek da bi ih na taj način prevladala $\mathrm{i}$ podredila interesima kapitalističke klase.

„Stoga 'uklopljenost' kao komponenta uklopljenog neoliberalizma zadovoljava interese bivših neomerkantilista kao i interese europskog radničkog pokreta i socijalno demokratskih političkih snaga, ali ti su interesi u konačnici podređeni onome što je postalo najvažnijim ciljem 'konkurentnosti' definirane u neoliberalnim terminima liberalizacije tržišta i tržišne discipline. Dapače, ono što se može nazvati neoliberalnim diskursom konkurentnosti, koji je podržavao društveno ekonomsko upravljanje EU tijekom 1990-ih, zapravo je postalo osovinom diskurzivne artikulacije uklopljenog neoliberalnog hegemonijskog projekta“" (van Apeldoorn 2009: 26).

Javne politike svih triju projekata, ugrađene u okvir uklopljenog neoliberalizma provode se $u$ kontekstu dvorazinskog upravljanja. Na nadnacionalnoj je razini uspostavljen sustav politika koje se odnose na potporu učinkovitosti tržišta. Nacionalnoj su razini prepuštene politike koje podupiru ciljeve uspostave jednakosti i socijalne sigurnosti. Van Apeldoorn (2009) navodi kako je ovim rascjepom ovlasti u EU oslabljena mogućnost nacionalnih država da ispravljaju 
zatajenja tržišta zbog nadnacionalno nametnutog imperativa „mehanizma regulacijske kompeticije" kojim se nastoji postići privlačenje i zadržavanje transnacionalnog kapitala. Izvor pritisaka na nacionalne države da povećavaju razinu konkurentnosti unutar jedinstvenog tržišta jesu Ekonomska i monetarna unija (EMU), Europska središnja banka te razne druge politike fiskalne discipline. Navedena bifurkacija ovlasti otežava nacionalnim državama donošenje socijalno-ekonomskih politika koje ujedno ne podrazumijevaju i politike neoliberalnog restrukturiranja. Europski je ekonomski sustav postavljen tako da se nacionalne države međusobno natječu u privlačenju mobilnog kapitala. U kontekstu tog međusobnog natjecanja, nacionalne države postaju sklonije provođenju strategija na strani ponude, kao što su, na primjer, deregulacija i fleksibilizacija rada, snižavanje poreznog opterećenja, smanjivanje opsega socijalnih politika, veća diferencijacija plaća; dok je vrlo malo politika usmjereno na državnu intervenciju s ciljem socijalne zaštite i ispravljanja zatajenja tržišta (van Apeldoorn, 2009). Van Apeldoorn (2009) na temelju diskurzivne analize predlagane Lisabonske strategije pokazuje kako u njoj postoje elementi neoliberalnog diskursa konkurentnosti, ali i elementi diskursa ostala dva konkurirajuća projekta neomerkantilizma i socijalne demokracije. Iako Lisabonska strategija nastoji integrirati interese neomerkantilizma i socijalne demokracije, izvjesno je da su ti interesi u diskursu podređeni politikama postizanja konkurentnosti, odnosno da su neutralizirani u okviru nadređenog im neoliberalnog diskursa. U Lisabonskoj strategiji ističe se važnost specifično europskog modela javnih politika kombinirajući težnju za konkurentnošću s mjerama „socijalne kohezije“, čime se nastoji istaknuti razlikovanje Europske unije od brutalnijeg, „nereguliranog“ kapitalizma Sjedinjenih Država i azijskih zemalja. Integracija ciljeva neoliberalne kompetitivnosti $\mathrm{i}$ socijalne kohezije artikulirana $\mathrm{u}$ diskursu teksta „Lisabonske strategije upućuje na predanost ne samo principu tržišta, već i principu socijalne zaštite, ali u toj se artikulaciji također može identificirati uvjetovanje i podređivanje postojanja socijalne zaštite poboljšanju konkurentnosti na tržištu. Pa se tako ističe potreba za provođenjem strukturnih reformi ne bi li se osuvremenio europski socijalni model. Spomenute strukturne reforme podrazumijevaju skidanje zaštita određenim sektorima i otvaranje tržišta, poboljšanje klime za posao i poduzetništvo te veću prilagodljivost i fleksibilnost na tržištu rada“ (van Apeldoorn 2009: 29). Apeldoorn citira fragmente iz dokumenta Vijeća Europe kako bi ilustrirao preoblikovanje socijalno-demokratskog diskursa i podređivanje neoliberalnoj agendi: „,socijalna je kohezija izjednačena s onim što se naziva 'moderniziranjem europskog socijalnog modela' (Vijeće Europe 2000: 8), koje prije svega podrazumijeva prilagođavanje radnika 'za život i izobrazbu u društvu znanja', uključujući između ostalog jačanje 'zapošljivosti' i stjecanje novih vještina kao sastavnog dijela 'cjeloživotnog učenja', što bi trebalo postati 'osnovnom 
komponentom europskog socijalnog modela' (Vijeće Europe 2000: 8,10)“ (Apeldoorn 2009: 29). Socijalna kohezija ovdje dakle podrazumijeva prilagođavanje tržišta rada potrebama jačanja konkurentnosti. U Europskoj uniji restrukturiranje se legitimira isticanjem potrebe za postizanjem konkurentnosti, koje se onda primjenjuje i na tržištu rada i to isticanjem pojma „zapošljivosti““ kojim se upućuje na fleksibilizaciju kao na najbolje rješenje za nezaposlenost. Spomenute interdiskurzivne formacije eufemiziranog neoliberalnog diskursa, odnosno neke vrste kompromisa između tvrđeg tržišno orijentiranog anglosaksonskog neoliberalnog diskursa i socijalno-demokratskog diskursa zapravo nailazimo u diskurzivnim artikulacijama politike Trećeg puta u Velikoj Britaniji, ali i još ranije u obliku njemačkog ordoliberalizma sa svojom sintagmom socijalnog tržišta i naglašavanjem socijalnih aspekata ekonomskih politika. Ekonomski diskurs Europske unije u tom smislu zapravo predstavlja donekle moderniziranu varijantu diskursa njemačkog ordoliberalizma.

$\mathrm{U}$ kontekstu formulacije identitetnih odnošenja neoliberalnih diskurzivnih formacija $\mathrm{s}$ onim kejnzijanskim, Thomas Palley (2005) pak ističe da je ideologija takozvanog Trećeg puta zapravo varijanta kejnzijanske doktrine, odnosno neka vrsta bastardizacije kejnzijanizma i neoliberalizma, s temeljnim argumentima o tržištu rada u koje su asimilirani određeni aspekti kejnzijanske ekonomike tvoreći tako interdiskurzivnu formulaciju onoga što bi se prema Phelanu (2007a, 2007b) moglo shvatiti kao eufemizirani diskurs neoliberalizma. Palley (2005) se usredotočuje na razlike između kejnzijanske ekonomske paradigme i one neoliberalne, promišljajući o načinima na koje je neoliberalna paradigma prevladala onu kejnzijansku. On pritom definira neliberalizam kao konzervativnu ekonomsku politiku koja se intelektualno nadovezuje na klasični i neoklasični liberalizam, s ponešto drugačijim naglascima na određene ekonomske principe kao što su učinkovitost tržišne konkurencije i individualizam kao osnove za određivanje ekonomskih ishoda te negativan utjecaj državnih intervencija i regulacije tržišta.

Dvije osnovne postavke neoliberalne paradigme oslanjaju se na dvije teorije, a to su teorija distribucije dohotka i determinacija agregatne zaposlenosti. Teorija distribucije dohotka tvrdi da su rad i kapital kao čimbenici proizvodnje plaćeni prema njihovoj stvarnoj vrijednosti koja je određena ponudom i potražnjom na tržištu. Teorija agregatne zaposlenosti tvrdi da oni čimbenici u procesu proizvodnje koji su vrijedni ne mogu propasti na slobodnom tržištu. Iz te tvrdnje proizlazi da će mehanizmom cijena doći do prilagodbe u potražnji što će dovesti do pune iskorištenosti svih čimbenika proizvodnje (kapitala i rada). Čikaška ekonomska škola u skladu s ovim teorijama poriče učinkovitost mehanizma monetarne i fiskalne politike u svrhu podizanja zaposlenosti jer smatra da se ekonomije automatski prilagođavaju postižući punu zaposlenost, dok potonji mehanizmi intervencionizma samo podižu inflaciju. 
Za razliku od neoliberalizma, kejnzijanska ekonomija stavlja naglasak na agregatnu potražnju kao osnovni čimbenik u stvaranju ekonomske aktivnosti pa time i razine zaposlenosti. S obzirom na to da u kapitalističkim ekonomijama agregatna potražnja periodički opada, dolazi i do opadanja zaposlenosti. Ukoliko su te fluktuacije osobito snažne, one dovode do recesija kao što je na primjer Velika gospodarska kriza, koje onda valja rješavati monetarnom i fiskalnom intervencijom kako bi se stvorila potražnja.

Ono što je prema mišljenju Palleya (2005) dovelo do uspona i današnje dominacije neoliberalne ekonomske filozofije jest jedan specifičan razdor među kejnzijancima, koji se tiče teorije distribucije dohotka. Kejnzijanci se mogu podijeliti na dvije struje kada je u pitanju navedena teorija: neokejnzijance ili Američku kejnzijansku školu te postkejnzijance ili Europsku kejnzijansku školu. Neokejnzijanci prihvaćaju navedenu neoliberalnu teoriju raspodjele dohotka koja se temelji na principu vrijednosti. Postkejnzijanci ukazuju na to da raspodjela dohotka uvelike ovisi i o institucionalnim čimbenicima. Dakle uz odnose ponude i potražnje na tržištu, postkejnizijanci naglašavaju i ulogu moći pregovaranja, koja ovisi o institucionalnom poretku. Dakle postkejnzijanci naglašavaju ulogu sindikata, radnih standarda kao što je minimalna plaća te sustava socijalne zaštite kao što je naknada za nezaposlenost. Ali isto tako, smatraju da je važna i javna percepcija ekonomije te javno raspoloženje prema sindikatima i institucijama socijalne zaštite. Ono što je prema Palleyu (2005) bio izvor neoliberalne agende fleksibilnosti tržišta rada može se naći u teoretiziranjima američkih neokejnzijanaca koji su smatrali da radnici dobivaju onolike plaće, kolika je vrijednost njihova rada poslodavcu. U okviru takvog razmišljanja, postaje jasno da su sindikati i drugi oblici intervencije na tržištu rada zapravo nepotrebni i mogu biti shvaćeni kao faktori narušavanja tržišnog natjecanja, a ne kao mehanizmi zaštite od zatajenja tržišta koje nastaje zbog nejednakosti u moći pregovaranja. „Keynes i kejnzijanci su u mnogočemu doprinijeli shvaćanju determinanti agregatne potražnje i njezinoj ulozi u određivanju ishoda zaposlenosti, ali nije bilo popratne analize uvjeta proizvodnje i načina na koje oni interagiraju s i utječu na agregatnu potražnju“ (Palley 2005: 22). Također, neokejnzijanci su smatrali da rigidnost nominalnih plaća i cijena stvaraju nezaposlenost. Rješenje za nezaposlenost koje je proizlazilo iz ovakve tvrdnje jest da će snižavanjem plaća doći do snižavanja cijena, čime će porasti vrijednost novca. Taj bi porast vrijednosti novca trebao poticati potrošnju, a niže cijene bi povećale realnu ponudu novca, što bi trebalo rezultirati snižavanju kamatnih stopa i stimulaciji investicija. Iz prethodno opisanog mehanizma proizlazi da niže nominalne plaće dovode do nižih cijena, što povećanjem investicija smanjuje stopu nezaposlenosti. 
Iz navedenih je neokejnzijanskih pretpostavki izvedena funkcija fleksibilnosti plaća i fleksibilnosti cijena te tvrdnja da rigidnost plaća i rigidnost cijena dovodi do nezaposlenosti. U tom smislu ova pozicija američkih neokejnzijanaca prethodi današnjem neoliberalnom zagovaranju fleksibilnosti na tržištu rada i prema Palleyju ona predstavlja neku vrstu iskrivljenog tumačenja izvornog kejnzijanizma u svrhu ojačavanja argumenata za provođenje neoliberalnih politika.

Na drugoj strani imamo postkejnzijance čija se perspektiva uvelike razlikuje od gore opisane po tome što oni naglašavaju da do nezaposlenosti dolazi zbog smanjivanja potražnje koju uzrokuje nesigurnost i slabo poslovno povjerenje. Potrošnja građana se smanjuje zbog nesigurnosti zaposlenja što ih potiče na čuvanje i gomilanje zaliha novca kao izvora sigurnosti u uvjetima radne i ekonomske nesigurnosti, a i sama fleksibilnost cijena može pogoršati potražnju zbog duga. Niže cijene i niže nominalne plaće povećavaju kamate na kredite, pa građani iz tog razloga smanjuju potrošnju ili čak prestaju biti u mogućnosti plaćati kredite (Palley 2005:22).

Palley (2005) uspoređuje pristupe postkejnzijanizma i Trećeg puta novih laburista. Treći put, on smatra, teži ostvariti kompromis između laissez-faire ekonomije i ekonomskog režima centralnog državnog planiranja te predstavlja svojevrsnu alternativu neoliberalnom pristupu javnim politikama. Treći put nastoji ublažiti rigidan tržišni pristup, međutim, on se razlikuje od pristupa postkejnzijanizma. Jednako kao što je Phelan $(2007 b, 2014)$ diskurs Trećeg puta smjestio u polje neoliberalnog, odnosno eufemiziranog neoliberalnog diskursa, tako i Palley (2005) ukazuje da je Treći put, u osnovi neuspješan u ulozi alternative neoliberalnoj koncepciji organizacije ekonomije i kreiranja javnih politika jer prihvaća osnovne teorijske postavke neoliberalizma. A to su već spomenute teorije raspodjele dohotka te stabilnosti kapitalističkih ekonomija. Treći put se protivi nacionalizaciji industrije jer smatra da je zatajenje državne regulacije gora opcija od zatajenja tržišta. Utoliko Treći put radije poseže za instrumentima oporezivanja i regulacije kako bi uspostavio ravnotežu na tržištu. Također, Treći put dopušta privatizaciju javnih usluga zdravstva i obrazovanja iako se pokazalo da privatni sektor, odnosno tržište u tim segmentima pruža lošije usluge. Palley (2005: 28) ističe da je Treći put različit od postkejnzijanizma $\mathrm{i}$ to $\mathrm{u}$ fundamentalnom smislu, jer postkejnzijanizam ne prihvaća neoliberalnu teoriju raspodjele dohotka te automatsku tendenciju tržišta rada ka stanju ravnoteže. Postkejnzijanizam smatra da na slobodnom neutralnom tržištu ne postoji „,prirodna tendencija“" pravedne naknade za rad, to jest da rad nije automatski plaćen onoliko koliko vrijedi. Tržišta imaju tendenciju favorizirati kapital na štetu rada, pa su iz tog razloga potrebne 
državne intervencije u obliku regulacije tržišta rada, kao i uspostavljanje institucija tržišta rada, kao što su sindikati i kolektivno pregovaranje. Postkejnzijanci drže da ne postoji ekonomsko opravdanje za uspostavljanje fleksibilnosti cijena i prihoda jer ona samo pogoršava problem nezaposlenosti koju uzrokuje periodički pad agregatne potražnje karakterističan za kapitalizam. Rješenja za pad agregatne potražnje, pa tako i za nezaposlenost valja tražiti u labavijim makroekonomskim politikama, odnosno u intervencijama povezanima s monetarnom i fiskalnom politikom koje će onda smanjiti ozbiljnost problema deficitarne potražnje i spriječiti deflaciju dugova (Palley 2005: 28). 


\subsection{Fleksibilizacija tržišta rada i neoliberalizam}

Postoji mnogo definicija fleksibilizacije i one se mogu razlikovati s obzirom na nekoliko razina općenitosti i perspektiva. Kod identificiranja i opisivanja procesa fleksibilnosti dolaze do izražaja ideološka nagnuća onih koji fleksibilnost definiraju, pa je moguće pri definiranju naglasiti različite aspekte fleksibilizacije ovisno o tome je li se fleksibilnost smatra procesom koji rezultira pozitivnim ili negativnim posljedicama, veže li se uz neoliberalne politike ili uz procese tehnološkog napretka i inovacija informacijskih tehnologija ili pak uz mikro procese organiziranja tvrtki te definira li se iz ekonomske, pravne ili sociološke perspektive. Kritičari fleksibilizacije spominju kako ona možda i jest zamišljena kao odgovor na tehnološke promjene povezane s postfordističkom akumulacijom, ali je zapravo postala standardnim dijelom provođenja neoliberalnih politika koji u tom aspektu imaju cilj podrediti interese rada akumulaciji kapitala.

Fleksibilizacija radnih oblika i tržišta rada kao tema pojavila se tijekom 1980-ih i 1990ih godina kada su globalne ekonomske promjene dovele do narušavanja stabilnosti kejnzijanske socijalne države, koju je popratio rast nezaposlenosti i sve izraženije ukazivanje na potrebu provođenja reorganizacije industrijske proizvodnje koja bi rezultirala fleksibilnošću kompanija, odnosno njihovom sposobnošću da se prilagođavaju konkurenciji i fluktuirajućoj potražnji na globalnim tržištima (Regini 2000, Bilić 2009). Fordistički se oblik masovne proizvodnje, s jasnim temeljima u standardiziranom sustavu pravila u organizaciji tvornica te standardiziranim normama i kriterijima u pregovaranju u industrijskim odnosima koji su vrijedili za sve oblike proizvodnje, transformirao u postfordistički model akumulacije kapitala što je popratila i tehnološka transformacija koja se odrazila na transformaciju organizacije industrije i radne snage. Fleksibilizacija tržišta rada na mikro razini povezana je s koncepcijom fleksibilnosti samih tvrtki, pa na mikrorazini možemo govoriti o nekoliko oblika fleksibilnosti:

a) numerička ili vanjska fleksibilnost koja se odnosi na smanjivanje troškova otpuštanja i zapošljavanja radnika. Numerička fleksibilnost ,predstavlja menadžerske kapacitete otpuštanja radnika kako bi se omogućilo smanjenje broja radnika ili zamjena radnika čije su vještine postale zastarjele, i korištenje novi oblika zaposlenja - kao što su atipični, privremeni ili povremeni rad - prilikom zapošljavanja novih radnika“ (Regini 2000: 16).

b) funkcionalna ili unutarnja fleksibilnost koja se odnosi na mogućnost poslodavca da premješta radnike na različita radna mjesta unutar kompanije ili da mijenja sadržaj njihova radnog mjesta. Funkcionalna fleksibilnost „odnosi se na sposobnost poslodavaca da reorganiziraju postojeću radnu snagu tako da se ona prilagođava novim tehnologijama i novim 
načinima korištenja ljudskih resursa sredstvima kao što su rotacija poslova, 'multi-skilling', prekvalifikacija, mobilnost i tako dalje“ (Kalleberg 1990: 18; prema Regini 2000: 16).

c) fleksibilnost plaća odnosi se na mogućnost poslodavca da mijenja iznose plaća „kao odgovor na promjene na tržištu rada ili uvjete konkurentnosti; odnosno da usvoje platne strukture i platne razine koje nisu u potpunosti određene kolektivnim ugovorima ili statutnom regulacijom“"(Regini 2000:17).

d) fleksibilnost radnog vremena odnosi se na mogućnost ,prilagođavanja količine korištenja rada u skladu s cikličkim ili sezonskim promjenama u potražnju varirajući broj sati rada u danu, tjednu ili godini, radije nego broja zaposlenika ili stupnja stabilnosti njihova zaposlenja“ (Regini 2000: 17). U ovaj se oblik fleksibilnost ubrajaju smjenski rad, prekovremeni rad i različiti tjedni ili godišnji rasporedi radnog vremena i slično.

Iz ovih se oblika fleksibilnosti jasno može razaznati zašto je fleksibilizacija tržišta rada prijeporno pitanje, s obzirom na to da unosi veliki stupanj nesigurnosti u radni aspekt života pojedinaca, i s tom svrhom podrazumijeva pritisak na prilagodbu nacionalnih regulativa, odnosno institucija tržišta rada koje bi trebale biti oblikovane na način da omogućuju provedbu fleksibilnosti u praksi na razini pojedinih tvrtki. Dakle, poslodavci smatraju da je sposobnost tvrtki da se prilagođavaju promjenjivim uvjetima na tržištu onemogućena zbog postojećih uvjeta koji vladaju na tržištima rada, a podrazumijevaju institucije tržišta rada koje kroz prava i zaštitu radnika poskupljuju rad. Taj skup pravila, odnosno institucija tržišta rada na središnjoj nacionalnoj razini, odnosi se na pitanja regulacije plaća, radnih sati, mobilnosti i ulaska na tržište rada, i sada počeo se smatrati preograničavajućim za uspješno poslovanje (Regini 2000).

Vlado Puljiz definira fleksibilizaciju tržišta rada kroz njezinu socijalnu dimenziju kao „uvođenje novih, atipičnih oblika zaposlenosti koji zamjenjuju stalnu zaposlenost, odnosno radni ugovor na neodređeno vrijeme. Fleksibilizacija znači ekspanziju aranžmana kao što je rad s djelomičnim radnim vremenom, rad na određeno vrijeme, povremeni rad, rad na distancu, telework, neovisni rad i slično“ (Puljiz 2009: 10-11). Čimbenici koji su povezani s procesom fleksibilizacije rada odnose se na širenje tehnoloških inovacija, globalizaciju, uspon individualizma i širenje tržišta javnih usluga.

Činjenica da fleksibilizacija rezultira prilično negativnim posljedicama za radnike, kao što su smanjivanje socijalne sigurnosti radnika i prekarnost, provođenje politika deregulacije i ukidanje uspostavljenih radnih zaštita kojima se ostvaruje fleksibilnost, dok se s druge strane može povezati uz tehnološki napredak i globalizaciju ekonomije dovodi do gotovo nerješivih prijepora u (javnim) raspravama o njezinoj opravdanosti i učincima pritom naglašavajući 
različite aspekte njezina nastanka i djelovanja. Gosta Esping-Andersen i Mario Regini (2000) ukazuju na dvije osnovne pozicije kada je riječ o prosudbi načina na koji treba provoditi fleksibilizaciju promjenom uloge pojedinih institucija tržišta rada ili njihovim uklanjanjem. Kada govorimo o diskursu o fleksibilizaciji tržišta rada, onda je moguće u njemu razaznati jasnu podjelu na zagovornike fleksibilizacije tržišta rada koji o njoj raspravljaju u pozitivnim terminima te na kritičare fleksibilizacije koji za navedeni termin i proces vezuju negativne konotacije. Zagovornici fleksibilizacije tržišta rada najčešće smatraju da treba ukloniti sve regulacijske prepreke koje onemogućavaju djelovanje tržišnih mehanizama. Što opsežnijim uklanjanjem regulatornih mehanizama na tržištu rada i njegovim oslobađanjem, zagovornici vjeruju da će se ostvariti optimalna situacija ostvarenja ciljeva zaposlenosti, smanjenja nezaposlenosti, učinkovitosti, produktivnosti i mobilnosti radne snage te pravedne raspodjele socijalne sigurnosti. Pod deregulacijom u kontekstu nastojanja da se tržište rada fleksibilizira podrazumijeva se „deregulacija pravila zapošljavanja i otpuštanja, određivanja plaće, radnog vremena te prihvaćanje značajnog smanjenja socijalne zaštite - odnosno smanjenje cijene rada, to jest smanjenje plaća, smanjenje uvjetne nadnice“ (Esping-Andersen i Regini 2000).

Kritičari, odnosno protivnici fleksibilizacije, ističu da deregulacija tržišta rada s jedne strane dovodi do nejednakosti koje mogu dovesti do društvenih sukoba, dok s druge strane ne postoje jasni pokazatelji koji bi ukazivali na to da reguliranost tržišta rada, odnosno njegova „rigidnost“ uzrokuje nisku zaposlenost, odnosno visoku nezaposlenost. Prema protivnicima fleksibilizacije tržišta rada, odgovornost za nepovoljnu situaciju što se tiče broja slobodnih radnih mjesta valja tražiti u restriktivnim makroekonomskim politikama, a ne visokoj razini radničkih prava i zaštite. Osim što je fleksibilizacija tržišta rada predmet prijepora među industrijskim akterima, fleksibilizacija kao suprotnost regulaciji tržišta rada predmet je kritika i u okviru akademske zajednice. Problem određivanja karaktera politika fleksibilnosti jest taj što se ona može povezivati s nekoliko različitih društvenih promjena koje se odvijaju istovremeno pa je moguće $u$ diskursu izbjegavati naglašavati percipirano negativne posljedice fleksibilizacije stavljanjem naglaska na pozitivnu stranu fleksibilizacije kako ju vide poslodavci ili ju smatrati neizbježnom posljedicom globalnih i tehnoloških promjena.

Fleksibilnost se na makrorazini također može promatrati dijelom projekta provođenja neoliberalnih politika. I prije nego što se pojam fleksibilnosti proširio kao poželjna karakteristika tržišta rada, neoliberalne su politike postupno počele deregulirati tržište rada. Taj je proces započeo početkom 1980-ih godina u Sjedinjenim Američkim Državama i Velikoj Britaniji dolaskom na vlast vlada Ronalda Reagana i Margaret Thatcher. U tim su godinama 
postupno ukidana socijalna jamstva za radnike, porastom stope nezaposlenosti sindikati su oslabljeni, čime su smanjene mogućnosti i prava na kolektivno pregovaranje. Upravo zahvaljujući tim ranim neoliberalnim politikama formirao se anglosaksonski model izrazito fleksibilnog tržišta rada koji se tijekom 1990-ih godina zagovarao u Europi kao odgovor na gospodarske probleme i stagnaciju tržišta rada u europskim zemljama.

Kritičari fleksibilizacije tržišta rada i deregulacije, Stanford i Vosko (2004), začetak neoliberalnog programa koji promiče deregulaciju tržišta rada nalaze u OECD-ovim preporukama izdanima 1994. godine pod nazivom OECD Jobs Study koja predstavlja konkretne upute o reformama na tržištima rada kako vi se povećala njihova „fleksibilnost“. Sam izraz fleksibilnost, prema nekim je autorima (McBride, McNutt i Williams 2007; Stanford i Vosko 2004: 11) izabran kako bi se pomoću njega lakše promicali standardni neoliberalni imperativi pogodovanja kapitalu, jer sama riječ fleksibilnost pobuđuje pozitivne konotacije i otežava formulaciju kritike usmjerene na spomenute politike, jer „napokon, tko bi uopće mogao zagovarati nefleksibilnost".

Preporuke OECD-a koje zagovaraju fleksibilizaciju tržišta rada utemeljene su na usporedbama drugih tržišta rada s onim u SAD-u, za čiji se uspjeh kada je u pitanju relativno niska stopa nezaposlenosti, pripisuje dereguliranosti i visokoj razini fleksibilnosti tamošnjeg tržišta rada. Preporuke agende fleksibilnosti obuhvaćaju široki raspon politika koje se sastoje od, na primjer, reformi sigurnosti prihoda koje podrazumijevaju uvjetovanje socijalnih naknada i naknada za nezaposlenost traženjem posla i radnim iskustvom te opće snižavanje iznosa spomenutih naknada. Među preporukama su i mjere smanjivanja utjecaja kolektivnog pregovaranja na razinu plaća zajedno s drugim dimenzijama radnog odnosa, promicanje prekarnih oblika rada kao što su rad s nepunim radnim vremenom, samozapošljavanje i slično. I napokon, kao treća komponenta fleksibilizacije tržišta rada jesu promjene u politikama obrazovanja i osposobljavanja pri čemu se obrazovni sustavi, odnosno kurikulumi i programi nastoje preoblikovati na način da u što većoj mjeri opslužuju potrebe privatnih poslodavaca, što se promiče kako kroz reformu školstva, tako i promicanjem cjeloživotnog obrazovanja čije troškove najčešće snose sami pojedinci. Prema Stanford i Vosko (2004) ovu fleksibilizaciju koja se odvija na nivou javnih politika prati i fleksibilizacija djelovanja privatnih tvrtki prema teoriji fleksibilne tvrtke američkog učenjaka Johna Atkinsona. Privatne tvrtke tako provode fleksibilne prakse zapošljavanja što podrazumijeva „nastanak niza novih praksi zaposlenja u kojima poslodavci imaju mogućnost lakše i brže mijenjati odluke o zaposlenju kako bi lakše reagirali na promjene u potražnji, istovremeno izbjegavajući odgovornost povezanu s 
pružanjem radne zaštite i radničkih prava“" (Stanford i Vosko 2004: 12). Ovakve prakse zapošljavanja kod privatnih kompanija rezultiraju povećanjem udjela prekarnih oblika rada među zaposlenima jer privatni poslodavci prekomjerno koriste, pa čak i iskorištavaju mogućnosti ušteda koje im donose politike deregulacije.

Proces fleksibilizacije u kontekstu njegova definiranja kao dijela agende provođenja neoliberalnih globalnih politika predstavlja „vraćanje 'discipline' na tržište rada“ koje se očituje u jednostranom, neoliberalnom shvaćanju fleksibilnosti u smislu sposobnosti da se brzo i uspješno reagira na neku promjenu. Za Stanford i Vosko, sama fleksibilnost u smislu prilagođavanja promjenama nije problematična, već je diskutabilna neoliberalna vizija fleksibilnosti koja često podrazumijeva „discipliniranije i okrutnije tržište rada, na kojem poslodavci mogu po volji otpuštati i zapošljavati radnike, na kojem su radnici prisiljeni na poslušnost, a razine novčane kompenzacije strogo limitirane“ (2004: 13). Takvo je tržište rada fleksibilno za poslodavce, ali pred radnike postavlja budućnost sumorne rigidnosti. U svakom je slučaju moguće, ali u kontekstu neoliberalnih politika ne i vjerojatno, ostvariti fleksibilnost tržišta rada u čijem je centru radnik sa svojim potrebama, kao što je primjerice često financijski uvjetovana mogućnost radnika da zadovoljavajuće kombinira plaćeni rad s neplaćenim aktivnostima, poput brige o djeci.

Stanford i Vosko (2004) opisuju način na koji se fleksibilizacija i deregulacija, u smislu procesa na tržištu rada, sagledavaju kroz prizmu interesa kapitala, pri čemu upućuju na jednostranu upotrebu riječi deregulacija i fleksibilizacija u neoliberalnom diskursu. Sama legitimacija neoliberalnih politika deregulacije i fleksibilizacije zasnovana je na doktrini slobodnog tržišta koja se može pronaći u zapisima neoliberalnih mislioca. Međutim, valja ukazati na to da se pojam deregulacije u neoliberalnom diskursu koristi selektivno, ignorirajući određene aspekte regulacije tržišta rada koji su korisni poslodavcima, odnosno kapitalu. Naime, ortodoksna neoliberalna ekonomska doktrina zagovara princip slobodnog tržišta kao optimalni regulacijski mehanizam za distribuciju poslova, pri čemu intervencije u slobodu tog tržišta deklarativno nisu poželjne bilo da dolaze od organiziranog rada ili od države, jer onemogućuju tržišni kliring i tržišno natjecanje te u konačnici stvaraju mnogo veće štete, nego što bi ikada moglo biti koristi od tih intervencija. Međutim, neoliberalne politike „deregulacije“ i „fleksibilizacije“ podrazumijevaju regulaciju i intervenciju države na području monetarne politike i regulacije kamatnih stopa. Zato na tržištu rada postoje rigidnosti i intervencije koje utječu na tržišnu raspodjelu poslova, pa je neoliberalna mantra o deregulaciji tržišta rada kao preduvjetu za uspostavljanje konkurencije i djelovanja mehanizama slobodnog tržišta samo 
parcijalan pogled koji uzima u obzir samo jednu vrstu regulacije tržišta rada, naime onu koja se odnosi na zaštitu rada i ujednačavanje odnosa moći između rada i kapitala. Dakle, Stanford i Vosko (2004) ukazuju na to da kada se zagovara deregulacija s ciljem fleksibilizacije onda to zapravo znači smanjivanje troškova rada na teret radnika. Pojmovi deregulacije i fleksibilizacije odnose se samo na jedan aspekt tržišta rada, a to je dio koji osigurava socijalnu sigurnost radnika koja za poslodavce znači dodatni trošak. Ako bismo govorili o deregulaciji i fleksibilizaciji tržišta rada u općem smislu, onda bi se ti pojmovi mogli odnositi i na smanjivanje regulacije tržišta rada koje pod paskom države provode središnje nacionalne banke uz pomoć održavanja tečaja i određivanja kamatnih stopa kako bi regulirale stopu inflacije. Iako se, kao što je ranije navedeno, u ortodoksnim doktrinama zastupa tržišna, a ne državna regulacija, valja uzeti u obzir da država u kontekstu širenja i implementacije neoliberalni politika ima ulogu facilitatora navedenog neoliberalnog programa. Kada se radi o politikama na tržištu rada prisutno je provođenje mjera koje $\mathrm{u}$ skladu $\mathrm{s}$ navedenom neoliberalnom doktrinom pretpostavljaju prirodnu minimalnu stopu nezaposlenosti koja odgovara ravnoteži na tržištu rada i koja se temelji na potencijalu izlaza (eng. output) agregatne ekonomije te koja ne smije pasti ispod spomenute razine. Mogućnost da stopa nezaposlenosti padne ispod određenog minimuma stvara opasnost da će zbog velike snage organiziranog rada porasti realne plaće i cijena rada što bi dovelo do potencijalne „inflacijske“ katastrofe. Zbog mogućnosti opisanog razvoja događaja, nacionalne središnje banke podešavaju kamatne stope tako da održavaju razinu nezaposlenosti iznad tog procijenjenog minimuma.

Definicije zagovaratelja fleksibilnosti najuobičajenije se svode na tehničke ekonomske definicije poput ove Muffelsa i Luijkxa (2008) koji nude definiciju fleksibilnosti kao „stupnja u kojem je tržište rada sposobno stvoriti prilike za poslodavce i radnike koje će im omogućiti zadovoljavanje potreba za kvalificiranim radnicima i odgovarajućim poslovima“ (Muffels i Luijkx 2008: 223). U samoj se definiciji jasno ogleda pozitivan predznak samog procesa fleksibilizacije, pri čemu se zanemaruju negativni učinci fleksibilizacije na radnike u obliku smanjenja zaštita i prava. Na fleksibilizaciju se gleda kao na nešto što je korisno i za same radnike i to kao stvaranje prilika zadovoljavanja potreba za odgovarajućim poslovima. U tom se kontekstu fleksibilizacija smatra dobrom za radnike jer omogućuje veću takozvanu mobilnost na tržištu rada, odnosno lakše mijenjanje posla s naglaskom na mogućnostima radnika da odaberu poslove koji im najbolje odgovaraju u kontekstu prilika koje im za to osigurava fleksibilno tržište rada. Također se ističe i fleksibilnošću potaknuta mogućnost da radnici uravnotežuju privatne i poslovne obaveze pomoću instituta fleksibilnog radnog 
vremena. Na primjer, Jasminka Kulušić (2009) definira fleksibilnost s manje-više diskretnim nagnućem tumačiti je pozitivno, unatoč tome što priznaje činjenicu postojanja negativnih učinaka na radnike:

„Makroekonomska definicija fleksibilnosti tržišta rada je ona definicija koja se odnosi na brzinu prilagodbe tržišta rada vanjskim udarcima ili promjenjivim ekonomskim okolnostima, pa fleksibilnost tržišta rada predstavlja stupanj do kojega se zaposlenost i/ili radno vrijeme (kvantitativna prilagodba) ili plaće (cjenovna prilagodba) prilagođuju ekonomskim promjenama.

Na mikro-razini iz perspektive poslodavaca fleksibilnost tržišta rada predstavlja situacije u kojoj institucije tržišta rada bezrazložno ne priječe mogućnost poduzeća da prilagode veličinu, strukturu i trošak svoje radne snage kretanjima na tržištu, a iz perspektive radnika, fleksibilnost tržišta rada znači niži stupanj zaštite na radnome mjestu i stoga veću vjerojatnost gubitka radnog mjesta, iako istodobno znači i veću mogućnost pronalaženja novog posla“" (Kulušić 2009: 49-50).

Priznavanjem negativnih učinaka fleksibilnosti na radnike, često se ističe mogućnost državno poduprijetih garancija sigurnosti na tržištu rada u sklopu pojma fleksigurnosti koja ujedno predstavlja prebacivanje troškova radničkih prava i zaštita s poslodavaca na državu.

\subsubsection{Neoliberalni diskurs o fleksibilizaciji tržišta rada}

Neoliberalna doktrinarna promišljanja o fleksibilizaciji, odnosno regulaciji tržišta rada i industrijskim odnosima utemeljena su na neoliberalnoj koncepciji optimalno funkcionirajućeg slobodnog tržišta, koje podrazumijeva pogled na odnose između rada i kapitala kroz prizmu ponude i potražnje, zanemarujući socijalne aspekte uklopljenosti tržišta rada u šire društvenopolitičke tokove. Kao što je već ranije navedeno, originalni tekstovi koji se povezuju s neoliberalizmom i njegovom ideologijom pripisani su glavnim doktrinarnim predstavnicima neoliberalne paradigme, odnosno pretežno Miltonu Friedmanu i Friedrichu Hayeku. Neoliberalna se doktrina sastojala od temeljnih tekstova čiji su se ekonomski principi širili znanstvenim institutima, organizacijama i publikacijama koje su novčano bile poduprijete od poslovnih krugova bliskih neoliberalnoj ideologiji. Kako je Phelan (2014) kritički istaknuo, sadašnja neoliberalna ideologija, i diskurs, može se promatrati kao mješavina različitih ekonomskih teorija i propozicija od kojih se neke povezuju sa izvornim tekstovima neoliberala, neke su prekrojene i osmišljene kasnije u spomenutim znanstvenim organizacijama, a mogu sadržavati i određene premise ekonomskih teorija koje po svojim karakteristikama ne moraju biti povezane s neoliberalnom paradigmom, ali ih je ona, neoliberalna ekonomika, u sebe 
asimilirala, stvorivši tako eufemizirani neoliberalni diskurs koji podrazumijeva podvrgavanje drugih ekonomskih teorija načelu i retorici slobodnog tržišta, odnosno slobodnog tržišta rada. U tom smislu su neoliberalne pretpostavke o tržištu rada uvijek utemeljene na retorici slobodnog tržišta, s primjesama drugih uvida u funkcioniranje tržišta rada prilagođenima neoliberalnoj globalnoj agendi provođenju politike deregulacije tržišta rada s ciljem pogodovanja kapitalu. Zapravo, izvorna se neoliberalna doktrina temelji na neoklasičnoj ekonomici slobodnog tržišta, koja je osuvremenjena i prilagođena naporu borbe protiv kolektivizma kejnzijanske socijalne države. Tijekom razdoblja kapitalizma socijalne države, nakon drugog svjetskog rata, uspostavljena je ravnoteža između rada i kapitala koja je trajala sve do sredine 1970-ih godina. Kriza koja je nastupila proizvela je društvenu i političku klimu mogućnosti implementiranja neoliberalnih politika čiji su temelj činile premise neoliberalne ideologije razvijane na temelju doktrina najznačajnijih predstavnika neoliberalne ekonomike. Određena su težišta klasične i neoklasične ekonomike preuzimana, ali je u tom procesu dolazilo i do premještanja naglasaka i prilagodbi neoliberalnoj politici što sačinjava sadržaj i nagnuća specifična za neoliberalnu ideologiju, ali i predstavlja način na koji se ona mijenja, nadopunjuje, osnažuje i danas (Blyth 2013, Phelan 2014).

Neoliberalna doktrina tržište rada tretira kao tržište roba, pa cjelokupan splet argumentacija koje se zalažu za fleksibilnost i deregulaciju temelji na teoretizacijama koje često niti nisu utemeljene na empirijskim istraživanjima ili su prilagođene osnovnom neoliberalnom argumentu o optimalnoj učinkovitosti mehanizama slobodnog tržišta (Jackson 2016). Neoliberalni argumenti kojima se promiče određeni oblik deregulacije, koji se usredotočuje na specifične institucije na tržištu rada koje reguliraju zaštitu i prava radnika, utemeljeni su na određenim neoliberalnim ideološkim inovacijama, a tiču se pogleda na samo tržište rada te na posljedice regulacije i djelovanje sindikata. Promjene u analizi prirode rada predstavljaju jednu od najvažnijih točaka u odnosu na koje možemo govoriti o „,neoliberalnoj ideologiji koja je oblikovana tijekom 1950-ih i 1960-ih godina i koja je postala utjecajni politički diskurs tijekom 1970-ih i 1980-ih godina“ (Jackson 2016: 263).

U kontekstu neoliberalne tvrdnje da tržišta optimalno funkcioniraju u uvjetima u kojima su slobodna od vanjskih intervencija države i neoliberalne pretpostavke da na tržištima rada vladaju jednaki uvjeti kao i na svakoj drugoj vrsti tržišta, izvodi se specifično neoliberalna doktrinarna pretpostavka da tržišta rada ne funkcioniraju prema svojim optimalnim kapacitetima jer su neslobodna i to zbog regulacije institucija tržišta rada nastalih pritiscima organiziranog rada na političke elite, odnosno državu. Međutim, samo podrijetlo teza koje 
proizlaze iz poistovjećivanja tržišta rada s tržištima robom i koje su neoliberali ugradili u svoju doktrinu, nije izravno povezano s teoretiziranjima klasičnih i neoklasičnih ekonomista, već joj se izvori mogu pronaći u jednoj struji američke škole kejnzijanizma (Palley 2005, Jackson 2016).

Ben Jackson (2016) tvrdi da se, kada je u pitanju tržište rada, neoliberalna doktrina razilazi s onim što bi se trebalo smatrati nasljeđem klasičnih i neoklasičnih ekonomista, pa čak i najznamenitijeg teoretičara Adama Smitha koji je u knjizi „Bogatstvo naroda“ iznio svoje shvaćanje odnosa na tržištu rada. Adam Smith se tako, u dilemi između vrijednosti slobodnog tržišta i državne intervencije, opredijelio za institucionalnu regulaciju gotovo isključivo kada je riječ o zaštiti na tržištu rada. Prema Adamu Smithu, jasno je da je poslodavcu potreban radnik jednako kao što radnik treba posao, ali nema sumnje da je radnik u tom odnosu u podređenom položaju, jer poslodavčeva potreba za radnikom nije toliko neodgodiva. Barem ne u mjeri koliko je radniku potreban posao kojim uzdržava sebe i vlastitu obitelj. Uz Adama Smitha, Jackson (2016) navodi i neoklasičnog mislioca Alfreda Marshalla koji je bio svjestan činjenice da se prodaja rada u mnogočemu razlikuje od prodaje drugih vrsta roba u tržišnoj ekonomiji. Jedan važni razlog zbog kojeg je prodaja rada specifična jest taj što među radnicima koje nude svoje usluge postoje različitosti koje se ne mogu ispravljati isključivo uspostavljanjem slobodnih samoregulirajućih tržišnih odnosa koji u teoriji znače jednake šanse za sve koji u njima sudjeluju. Naprotiv, kod prodaje rada situacija je drugačija jer postoji nejednaka raspodjela dostupnosti stjecanja vještina koje radnici mogu nuditi na tržištu rada, a ta dostupnost ovisi o dostupnosti ekonomskih i kulturnih resursa tijekom odrastanja koje sam radnik ne može kontrolirati. Dakle individualni radnik ne može samostalno utjecati na kombinaciju i kvalitetu vještina koje nudi na tržištu u zamjenu za plaću. Drugi razlog zašto je prodaja rada posebna vrsta transakcije jest taj što da bi prodao svoj rad u zamjenu za plaću, radnik mora biti prisutan na radnom mjestu. Istovremeno, radnik najčešće nema nikakvu kontrolu nad organizacijom radnog mjesta te se iz tog razloga, u procesu prodaje svog rada, suočava s raznim ograničenjima koja pred njega postavlja sama radna okolina. Radnik se također može naći u nepovoljnoj poziciji u odnosu na poslodavca ako i kada se njegove vještine, u koje je uložio veliku količinu truda i vremena, ispostave zastarjelima i nepotrebnima zbog nekih nepredvidljivih promjena na tržištu. U tom će slučaju pozicija radnika na tržištu rada postati značajno otežana (Jackson 2016). Marshall je kao i Adam Smith, ustvrdio kako su manualni radnici kao klasa u lošijoj pregovaračkoj poziciji, i to zato što su ,prodavači rada često suočeni sa specifičnim 'nepovoljnim položajem' u toj transakciji zbog 'blisko povezane skupine činjenica da radna 
snaga nije trajno dobro, da su oni koji je prodaju često siromašni i nemaju rezervna sredstva te da je ne mogu lako uskraćivati na tržištu'“ (Jackson 2016: 263).

Ukoliko odnose između radnika i poslodavaca shvatimo kao odnose ponude i potražnje na tržištu jasno je da između radnika i poslodavaca postoji određena razina sukoba interesa pri čemu poslodavci nastoje povećati profit smanjivanjem cijene rada kao čimbenika $u$ proizvodnom procesu, dok radnici nastoje ostvariti što veću razinu materijalnih kompenzacija, sigurnosti i zadovoljstva radnim uvjetima. Kako bi ostvarili svoje ciljeve, i jedna i druga strana nastoji utjecati na pravila koja uređuju načine na koje je moguće sklapati dogovore na tržištu. Ta se pravila odnose na određivanje i provođenje formalnih i neformalnih procedura i svaka od strana ih nastoji urediti na način da im se olakša ostvarivanje vlastitih interesa. Pregovori radnika i poslodavaca o uvjetima i pravilima koja uređuju odnose zaposlenosti prepuni su sukoba i kompromisa, a predstavljaju proces uspostavljanja regulacije tržišta rada koji se može definirati kao „skup formalnih i neformalnih zakona, institucija, politika i kulturnih stavova koje organiziraju i omeđuju odnose i prakse plaćenog rada“ (Stanford i Vosko 2006: 5). Rezultat pregovora između radnika i poslodavaca jesu institucije tržišta rada koje imaju ulogu ispravljati nesavršenosti tržišta rada, pa je moguće prihvatiti i stajalište da ono funkcionira sličnije jednoj socijalnoj instituciji, nego tržištu (Regini 2000, Argandona 2001). Tržišta rada mogu se smatrati najreguliranijim područjem zapadnih ekonomija, a reguliraju ga institucije tržišta rada koje Boeri i van Ours definiraju kao "sustav zakona, normi ili konvencija nastalih iz kolektivnog odabira, koji stvara poticaje ili ograničenja individualnim izborima koji se tiču rada i plaće", a kao primjere institucija tržišta rada možemo navesti kolektivno pregovaranje, sindikate, minimalnu plaću ili doprinose na plaće (Boeri, van Ours 2008: 3). Institucije tržišta rada uspostavljene su političkim odabirom te imaju određene funkcije u koje spadaju: (1) postizanje efikasnosti tržišta ispravljanjem nesavršenosti zbog kojih tržišta rada nemaju svojstva kompetitivnih tržišta, (2) postizanje optimalnog načina preraspodjele resursa. Dakle, osim ekonomskih razloga postojanja institucija tržišta rada (ispravljanje zatajenja tržišta, poboljšanje efikasnosti, snižavanje troškova, poticanje masovne potrošnje), važne su i socijalne i političke funkcije tih institucija kao što su proširenje građanskih prava, postizanje konsenzusa, društvena jednakost i redistribucija bogatstva, a sve one olakšavaju uspostavljanje društvenog ugovora između rada i kapitala (Regini 2000, Argandona 2001, Boeri i van Ours 2008). Tako Jamie Peck smatra da „(..) tržišta rada nisu kao tržišta robe: cijene ne koordiniraju ponudu i potražnju, sudionici ne ulaze u tržište ravnopravni jedni drugima, a robe se ne premještaju - u apsolutnom smislu zakonskog posjedovanja - s prodavača na kupca“ (Peck 1996: 2). 
Boeri i Van Ours (2008) ističu važnost institucija tržišta rada u ispravljanju nesavršenosti tržišta rada osobito u onom dijelu koji se tiče snažnije pozicije poslodavaca. Naime, bez organiziranog rada i pregovora između industrijskih aktera koji onda nastoje uspostaviti pravila koja utječu na djelovanje tržišnih mehanizama, tržište rada bilo bi sklono prelaziti u stanje monopsonije. Naime, monopsonija je stanje slično monopolu u kojem, za razliku od monopola kada na tržištu postoji samo jedan prodavatelj robe ili usluga što mu omogućuje kontrolu cijena, postoji samo jedan kupac koji onda može određivati po kojoj će cijeni kupovati robu ili usluge. Citat iz knjige Bogatstvo naroda Adama Smitha ukazuje na bojazan od te situacije:

„Nemamo nikakvih zakona izglasanih u Parlamentu protiv udruživanja radi snižavanja cijene rada; ali imamo mnoge protiv udruživanja za njezino podizanje. U svim takvim sporovima gospodari mogu izdržati mnogo dulje. Zemljoposjednik, farmer, vlasnik proizvodnje, trgovac, kada ne bi zaposlili niti jednog radnika, mogli bi živjeti godinu ili dvije s onim što su zaradili. Mnogi radnici ne mogu izdržati ni tjedna, malo ih može izdržati mjesec, a gotovo niti jedan godinu dana bez zaposlenja. Dugoročno, radnik može biti potreban svojem gospodaru kao što je njegov gospodar njemu; ali ta potreba nije toliko hitna. Rijetko kada čujemo da se priča o udruživanjima gospodara, ali često o udruživanjima radnika. Ali tko god si zamišlja da se, prema ovakvim svjedočenjima, gospodari rijetko udružuju, živi u neznanju o svijetu, kao i o temi. Gospodari su uvijek i svugdje u nekoj vrsti prešutne, ali konstantne i jednoobrazne sloge da neće podizati plaće iznad njihove tadašnje stope“ (Smith 1904[1776]: 69; prema Jackson 2016: 262).

Zato je rješenje nepravilnosti na tržištu rada sustav kolektivnog pregovaranja koji omogućuje uspostavljanje institucija tržišta rada koje onda ispravljaju lošiju poziciju radnika na tržištu rada u odnosu na poslodavce koji kupuju tu radnu snagu. U kontekstu klasične, odnosno neoklasične ekonomske teorije, uloga sindikata nije se svodila na dilemu u terminima pozitivnog ili negativnog utjecaja sindikata na odnose na tržištu rada, već su utjecaj i djelovanje sindikata smatrani u najmanju ruku složenim pitanjem. S jedne su strane aktivnosti sindikata smatrane poželjnima jer sprječavaju poslodavce da smanjuju plaće ispod razine tržišnog ekvilibrija, omogućuju podizanje plaća u razdobljima visokih profita te uravnotežuju društvenu i ekonomsku moć poslodavaca u odnosu na radnike (Jackson 2016: 263).

Međutim, među ranim ekonomskim misliocima oduvijek je postojao i strah od kolektivnih akcija sindikata, koji u slučaju prevelike koncentracije moći imaju potencijal 
prerastati u nasilne društvene poremećaje. Prihvaćanje stvarne potrebe za kolektivnim udruživanjem radnika u svrhu uspostavljanja ravnoteže moći između rada i kapitala ipak je ostao teorijski konsenzus među ekonomskim misliocima sve do polovice dvadesetog stoljeća. Neoliberalni se diskurs manifestira u obliku argumentacija na kojima se temelje opravdanja za promjenu ravnoteže odnosa na tržištu rada kroz zagovaranje povlačenja institucionalne regulacije na tržištu rada pred neoliberalnim principima samoregulirajućeg tržišta, odnosno zagovaranje promjene radnih zakona s ciljem oslabljivanja institucija tržišta rada te negiranje potrebe zaštite radnika od tržišnih nepravilnosti i neuravnoteženog odnosa snaga $u$ pregovaranju s poslodavcima.

Politički diskurs neoliberala tijekom 1970-ih i 1980-ih godina usmjeravan je prema diskreditiranju uloge sindikata u zastupanju interesa radnika koji su u odnosima na tržištu rada, kao što je ranije opisano, prepoznati kao slabija strana u pregovaračkoj poziciji oko prodaje vlastite radne snage. Naime, neoliberalna je doktrina preokrenula ovu hipotezu, odnosno dovela je u pitanje tvrdnje da su radnici slabija strana u radnim odnosima smatrajući da su na slobodnom tržištu rada kapital i rad u najmanju ruku ravnopravni, ali s obzirom na to da radnike štite moćni sindikati, koji uspostavljaju institucije tržišta rada koje im omogućuju stvaranje monopola i ometanje regulacijske uloge slobodnog tržišta, radnici zapravo zauzimaju jaču poziciju na tržištu rada od poslodavaca. Tvrdnja da su poslodavci i radnici u jednakom položaju te da su poslodavci često čak i u goroj pregovaračkoj poziciji zbog toga što djelovanje sindikata narušava postojeću ravnotežu na tržištu rada utemeljila diskurzivno tretiranje sindikata kao nepotrebnih ili čak nepoželjnih aktera na tržištu rada. Time su se sindikati i organizirani rad, barem u okviru neoliberalnog diskursa, sveli na samo jednu od barijera slobodnom samoregulirajućem tržištu; barijera koju treba savladati politikom deregulacije, odnosno fleksibilizacije tržišta rada. Postojanje sindikata prema neoliberalnom je diskursu postalo upitno jer ono čini poslodavce ranjivijima na tržištu rada od samih radnika koji su sada viđeni kao prezaštićena strana. Jackson (2016) je opisao tu doktrinarnu prekretnicu u shvaćanju sindikata i industrijskih odnosa, a koja se kasnije artikulirala kroz neoliberalni diskurs prateći politiku fleksibilizacije na tržištu rada, na sljedeći način:

„Zaposlenici, ustvrdili su, imaju pozamašan izbor i mogućnost mobilnosti kada se radi o prilikama zapošljavanja, dok su poslodavci suočeni s moćnim interesima rada koji su spremni koristiti silu iznude kako bi postigli svoje ciljeve. Ključna politička implikacija neoliberalnog poricanja činjenice da je rad posebna vrsta robe bila je ta da legislativna intervencija u službi izjednačavanja pregovaračke moći poslodavaca 
i posloprimaca zapravo privilegira sindikate, stvarajući moćne i državom poduprijete interesne skupine koje ometaju djelovanje tržišta i prijete samom legitimitetu države. Sindikati su okarakterizirani kao monopoli koji nastoje kontrolirati cijenu rada kako bi za nju naplaćivali cijenu koja je mnogo viša od cijene na razini konkurentnosti“"(Jackson 2016: 263-264).

Ovakva je teorijska pozicija neoliberala bila strateški usmjerena na to da ospori sindikalni legitimitet koji se temeljio na postavci da su sindikati odraz borbe običnih radnika i simbol odupiranja eksploataciji kapitalista te da ukazuju na negativnosti koje proizlaze iz monopola sindikata na tržištu rada. Neoliberalni je diskurs artikulacija neoliberalne ideologije kojom se nastoje promicati i legitimirati neoliberalne politike na tržištu rada.

Specifičnosti neoliberalnog shvaćanja tržišta rada, mogu se podijeliti na nekoliko linija argumentiranja u okviru neoliberalne ideologije slobodnog tržišta koja svoje teze o funkcioniranju idealnog tržišta utemeljenog na konkurentnosti, proširuje i primjenjuje analizirajući tržište rada. U okviru neoliberalnog tumačenja neoklasične ekonomike slobodnog tržišta, regulacija je prikazana kao neopravdano i egzogeno uplitanje u tržišne odnose čija je posljedica ekonomska neučinkovitost, odnosno zaštita od tržišnih sila konkurencije. Kako zbog regulacije tržišta rada nisu konkurentna tržišta, dolazi do negativnih pojava kao što su širenje nezaposlenosti, odnosno barijera zaposlenosti, kao i do isključivanja određenih skupina radnika s tržišta rada. Postoji nekoliko linija argumentacija prema kojima neoliberalni mislioci zagovaraju deregulaciju, odnosno fleksibilizaciju, pa čak i ukidanje kolektivnog pregovaranja, a utemeljeni su na promicanju slobodnog tržišta i individualizma. Većina se argumenata svodi na utvrđivanje mehanizama na koje institucije tržišta rada i sindikati negativno utječu na tržište te promicanje deregulacije, odnosno fleksibilizacije kao načina ostvarenja konkurentnosti na tržištu rada koje garantira bolju, odnosno pravedniju prilagođenost raspodjele poslova prema potrebama pojedinaca. Tako na primjer, Jackson (2016), opisuje poglede neoliberalnih mislioca kao što su, Hayek ili Friedman, na institucije tržišta rada koje proizlaze iz neoliberalnog pogleda na tržište rada, a koji se odnose na :
a) neoliberalno shvaćanje odnosa između sindikalnog udruživanja i nezaposlenosti i
b) neoliberalno shvaćanje ekonomskog odnosa između sindikata i nejednakosti;
c) neoliberalno shvaćanje ekonomskog odnosa između sindikata i inflacije; 
d) neoliberalni pokušaj da se u potpunosti rastoči jezik klase promicanjem alternativnih diskursa o ,ljudskom kapitalu“ i ,interesima proizvođača i potrošača“ (Jackson 2016: 262).

Za razliku od diskursa socijalne države kejnzijanski orijentiranih ekonomista, karakteristika neoliberalnog diskursa je njegovo postojano nastojanje da ukaže na to kako sindikati ne predstavljaju interese radnika, niti ih štite od eksploatacije vlasnika kapitala. Prema tvrdnjama neoliberalno orijentiranih ekonomskih stručnjaka, od klasičnih predstavnika neoliberalne paradigme do novijih razvoja u neliberalnoj doktrini, posljedica kolektivnog pregovaranja i djelovanja sindikata je, štoviše, povećanje stope nezaposlenosti, jačanje segmentacije tržišta rada te povećanje nejednakosti u prihodima radnika(Jackson, 2016). Legitimitet ove tvrdnje nije utemeljen na empirijskim istraživanjima, već u pozadini ove karakteristično neoliberalne tvrdnje stoji logika izvedena iz neoliberalne ekonomike koja počiva na uvjerenju da je tržište rada gotovo istovjetno tržištu roba i da se može približiti „,idealnom“ tržištu čiji se mehanizmi temelje na čistom tržišnom natjecanju.

\section{Neoliberalna argumentacija o utjecaju regulacije tržišsta rada $i$ sindikata na nezaposlenost $i$ nejednakost}

Gosta Esping Andersen i Mario Regini (2000) kažu da kada je riječ o načinima na koje treba provoditi fleksibilizaciju tržišta rada deregulacijom, odnosno promjenom uloge ili uklanjanjem pojedinih institucija tržišta rada, postoje dva suprotna stava koja karakteriziraju javne rasprave o mogućnostima fleksibilizacije tržišta rada. Dakle, kada je riječ o diskursu o fleksibilizaciji tržišta rada, onda je moguće u tom diskursu razaznati jasnu podjelu na zagovornike fleksibilizacije tržišta rada koji o njoj raspravljaju u pozitivnim terminima te na kritičare fleksibilizacije koji za navedeni termin i proces vezuju negativne konotacije. Zagovornici fleksibilizacije tržišta rada deregulacijom smatraju da treba ukloniti sve regulacijske prepreke koje onemogućavaju djelovanje tržišnih mehanizama. Što opsežnijim uklanjanjem regulacijskih mehanizama na tržištu rada i njegovim oslobađanjem, zagovornici vjeruju da će se ostvariti optimalna situacija ostvarenja ciljeva zaposlenosti, smanjenja nezaposlenosti, učinkovitosti, produktivnosti i mobilnosti radne snage te pravedne raspodjele socijalne sigurnosti. Deregulacija u kontekstu nastojanja da se tržište rada fleksibilizira shvaćena je kao „deregulacija pravila zapošljavanja i otpuštanja, određivanja plaće, radnog vremena te prihvaćanje značajnog smanjenja socijalne zaštite - odnosno smanjenje cijene rada, to jest smanjenje plaća, smanjenje uvjetne nadnice“ (Esping-Andersen i Regini, 2000). Gore spomenute tvrdnje o učincima regulacije, odnosno deregulacije vuku svoje podrijetlo $u$ 
neoliberalnim, osobito Hayekovim (2011) tvrdnjama o utjecaju sindikata na funkcioniranje tržišta rada, a time i na učinkovitost čitave ekonomije. Neoliberalni argument usmjeren protiv regulacije kao uzroka nezaposlenosti i nejednakosti može se povezati s Hayekovim izlaganjima o tome kako na tržištu rada, zbog sindikata nastaju monopoli rada (Deakin i Wilkinson 1994, Turner 2008, Jackson 2016). Naime, zbog uspostavljene regulacije na tržištu rada koja u nekim aspektima pogoduje sindikatima, sindikati su u položaju da stvaraju monopole rada, odnosno imaju prilike utjecati na cijenu rada, koja bi se prema neoliberalnim misliocima trebala formirati na tržištu prema uvjetima ponude i potražnje. Sindikati svojim djelovanjem na tržištu rada podižu plaće već zaposlenim radnicima, a vlasnici kapitala, odnosno poslodavci, ukoliko žele smanjiti troškove poslovanja, pribjegavaju zapošljavanju manjeg broja radnika zbog čega dolazi do porasta stope nezaposlenosti. Osim što pretjerana reguliranost tržišta rada, uzrokuje nezaposlenost, ona postaje i uzrokom nejednakosti između radnika na tržištu rada. Porast stope nezaposlenosti dovodi do stvaranja velikih skupina nezaposlenih koji su dostupni za rad na nisko plaćenim poslovima, u kojima ne postoji sindikalno udruživanje. Iz ove neoliberalne logike proizlazi karakteristično neoliberalno shvaćanje sindikata prema kojemu oni predstavljaju instrument privilegiranja zastupane skupine radnika na štetu radnika koji nisu sindikalno organizirani. Radni standardi na taj način sprječavaju pravilno funkcioniranje tržišta. Optimalna alokacija i mobilnost kao osnovna funkcija tržišta rada poremećena je upravo zbog postojanja radnih standarda. U okviru navedene argumentacije, sindikati su opisani kao akteri koji stvaraju monopole ili kartele na tržištima svojim aktivnostima kolektivnog pregovaranja i kontrole poslova. Navedeni „karteli“ pogoduju interesima organiziranog rada, i to na štetu „outsidera“ u koje spadaju i nezaposleni. Djelovanje organiziranog rada na taj način stvara dodatne ekonomske troškove, a prema neoliberalnoj teoriji ,pravne intervencije su posljedica aktivnosti interesnih skupina osmišljenih da štite 'insidere' od tržišnih sila konkurencije“ (Deakin i Wilkinson 1994: 293). U kontekstu ovakve argumentacije sindikati zapravo imaju svoj udio u stvaranju društvene nejednakosti. Ono što neoliberalna paradigma predlaže kao rješenje opisanih problema jest deregulacija i smanjivanje udjela kolektivnog, a povećanje udjela individualnog pregovaranja.

Ovakva je percepcija tržišta rada u svrhu zalaganja za njegovu deregulaciju i fleksibilizaciju uklanjanjem institucija na tržištu koje prema neoliberalnom viđenju omogućuju sindikatima da stvaraju monopole kritizirana na više razina: kritizira se logika i racionalnost njezina ekonomske utemeljenosti, ali i nedostatak empirijskih pokazatelja koji bi ukazivali na njezinu ispravnost. Prva kritika spomenutoj argumentaciji spočitava shvaćanje tržišta rada u 
terminima simplificiranog ekonomizma koji ne uzima u obzir društvenu uklopljenost tržišta rada i utjecaj neekonomskih čimbenika na samu dinamiku tržišta (Granovetter 1992, Peck 1996). Naime, tržišta rada nikada ne mogu postići stanje pune konkurentnosti u onom smislu u kojem to predviđa neoliberalna ekonomika, odnosno u smislu uravnoteženosti, jer ih karakteriziraju strukturalne nesavršenosti. Iz tog razloga postupni prijelaz iz kolektivnog pregovaranja $\mathrm{u}$ individualno pregovaranje u kojem bi potonje postalo dominantno na tržištu rada, ne bi polučio željeni učinak uspostavljanja kompetitivnog tržišta. Prema teorijama efikasnosti plaća, regulacija poslova koja štiti senioritet i barem donekle garantira određenu razinu zaštite radnog mjesta osigurava veću produktivnost i lojalnost radnika poslodavcu što osigurava dugoročne uštede, a i druge pogodnosti za poslodavca. Poslodavci, prema teorijama efikasnosti plaća, nastoje osigurati predanost i lojalnost radnika pa im čak i uvjetima kada je situacija na tržištu rada takva da postoji velika ponuda radne snage ili veliki pad u potražnji, ne smanjuju plaće ili druge beneficije koje predstavljaju trošak za poslodavca. Iz toga se može zaključiti da određeni dio radne snage u tvrtkama nije izložen uvjetima konkurencije na tržištu rada koji bi im u određenoj ekonomskoj situaciji, kao što je na primjer krize, postupno snižavali plaće ili neka druga prava.

Teorija segmentacije tržišta rada pokazuje da na tržištu rada postoji nekoliko skupina radnika koje se na primjer mogu razlikovati po spolu ili rasi i koje zbog tih svojih razlikovnih karakteristika imaju različite razine plaća. Uzimajući u obzir navedene razlike i propozicije teorije segmentacije tržišta rada dolazi se do zaključka da visina plaće u mnogim slučajevima ne ovisi o produktivnosti radnika koja bi određivala vrijednost njegova rada na tržištu, već visina plaće može biti povezana s njegovom pripadnošću određenoj skupini radnika na tržištu, a koji zbog nekih svojih karakteristika imaju niže plaće. Iz tog je razloga vrlo teško na tržištu rada empirijski potvrditi povezanost između plaća i relativne produktivnosti radnika. Naime, iako plaće mogu biti određene uvjetima na tržištu, to ne znači da će njihova relativna visina na bilo koji način ukazivati na razinu produktivnosti radnika. Upravo zbog spomenute segmentacije tržišta rada, poslodavcima je zapravo omogućeno plaćati manje iznose određenim skupinama radnika na tržištu koji potencijalno imaju jednake sposobnosti ili rade jednakom razinom produktivnosti.

„Ova mogućnost dostupnosti podcijenjenog rada sama po sebi predstavlja izvor produktivne neučinkovitosti poslodavaca, opskrbljujući kompanije sredstvima kompenzacije za menadžerske, organizacijske i druge oblike nedostatnosti, odgađajući odbacivanje zastarjele kapitalne opreme i omogućujući konkurentnost 
cijena utemeljenu na snižavanju cijene plaća, povećavajući ovisnost plaćenih radnika o socijalnoj zaštiti. Slijedom navedenoga, 'neregulirana' tržišta rada stvaraju lažne standarde rada koje je moguće suzbiti jedino institucionalnom intervencijom usmjerenom na osiguranje kako veće jednakosti prilika tako i jednakosti u ophođenju s radnicima“"(Deakin i Wilkinson 1994: 294).

Kao što je već navedeno, ova neoliberalna argumentacija u svojem temelju usmjerena protiv regulacije tržišta općenito, a osobito protiv kolektivnog pregovaranja i djelovanja sindikata. Međutim, prema empirijskim istraživanjima ne postoje jasni indikatori koji bi ukazivali na to da regulacija, „rigidnost“, uzrokuje nezaposlenost s čime se slažu čak i zagovaratelji fleksibilizacije tržišta rada poput na primjer Jasminke Kulušić (2009). Jednako tako nema nedvosmislenih pokazatelja utvrđenih u empirijskim istraživanjima da deregulacija, odnosno fleksibilizacija, omogućuje otvaranje novih radnih mjesta ili da povećava stopu zaposlenosti (Esping-Andersen 2000). Boeri i van Ours (2008) tako uspoređuju EPL indeks i stope (ne)zaposlenosti pojedinih zemalja u Europi pri čemu ne nailaze na pokazatelje koji bi upućivali na to da se promjenom indeksa zakonske zaštite zaposlenja može utjecati na razine nezaposlenosti. I jedni i drugi, međutim ustvrđuju da postoji povezanost između zakonske zaštite zaposlenja i strukture nezaposlenosti pri čemu nezaposlenost prevladava među mladima, niskokvalificiranima i ženama. Teorija segmentacije tržišta rada može dakle biti korištena kao argument za fleksibilizaciju i protiv fleksibilizacije. Naime, s obzirom na to da postoje fleksibilni oblici rada i standardni radni odnos na neodređeno, tržite rada je podijeljeno na „insidere“ i „ousidere“. Rješenje dakle može biti gotovo potpuna deregulacija i fleksibilizacija tržišta rada što bi dovelo do demokratizacije nezaposlenosti, ili pak ukidanje fleksibilnih ugovora o radu. Unatoč postojanju dvaju opisanih divergentnih stavova o fleksibilizaciji u javnoj političkoj raspravi u Europi, u većini zemalja Europske unije vlade ne posežu za posvemašnjom fleksibilizacijom tržišta rada, jer nitko zapravo ne vjeruje da reguliranost predstavlja osnovni problem kada se radi o otvaranju radnih mjesta. Utoliko je ovaj stav reflektiran i u politikama na tržištu rada koje rijetko idu u smjeru približavanja potpunoj deregulaciji već se uvijek radi o doziranim pristupima intervenciji u smanjivanje zaštite radnika, vjerojatno zbog tradicionalne europske sklonosti egalitarnim vrijednostima. Iako ne postoje konkretni dokazi da reguliranost tržišta rada utječe na razinu zaposlenosti i mogućnosti otvaranja radnih mjesta, postoje pokazatelji koji ukazuju na to da ona utječe na strukturu nezaposlenosti, odnosno utječe na to tko su nezaposleni. 
Također, nedavna empirijska istraživanja utjecaja sindikata na tržište rada nude mnogo složeniju sliku situacije na tržištu rada od one koju opisuju neoliberalna promišljanja. Naime, pokazalo se da sindikati smanjuju razlike u plaćama na određenim radnim mjestima i u određenim industrijama te da se pod utjecajem sindikata smanjuju razlike između plaća radnika na manualnim poslovima i radnika na poslovima karakterističnima za srednju klasu. Dodatni pozitivan utjecaj sindikata na tržište rada primijećen je u obliku smanjivanja obrtaja osoblja. Naime, sindikati radnicima pružaju nešto što se naziva „kolektivnim glasom“, odnosno u ime radnika mogu davati korisne povratne poslodavcima o pitanjima organizacije rada i radnih uvjeta (Jackson, 2016). Jackson ukazuje na to da iako neoliberalne tvrdnje o utjecaju sindikata na tržište rada nisu empirijski utemeljene, one su kontinuirano vršile utjecaj na političare sklone neoliberalnim idejama. Prema Jacksonu (2016) politička implikacija tih tvrdnji jest prebacivanje tereta odgovornosti za postojeće stope nezaposlenosti s države na sindikate. „Ako su primarno 'rigidnosti' na tržištu rada, kao što je sindikalna gustoća, te koje sprječavaju poslodavce da zapošljavaju, onda će postizanje viših stopa zaposlenosti prirodno zahtijevati napore da se barijere učinkovitoj kupnji i prodaji rada sruše“" (Jackson 2016: 265). Također bi to značilo smanjenje podupiranja tradicionalnih kejnzijanskih metoda povećanja zaposlenosti, a to se uglavnom odnosi na poticanje agregatne potrošnje. Prema neoliberalnim shvaćanjima, radni standardi na taj način sprječavaju pravilno funkcioniranje tržišta. Odnosno, optimalna alokacija i mobilnost kao osnovna funkcija tržišta rada poremećena je upravo zbog postojanja radnih standarda. Kritičari, odnosno protivnici fleksibilizacije, ističu da deregulacija tržišta rada s jedne strane dovodi do nejednakosti koje mogu dovesti do društvenih sukoba, dok s druge strane ne postoje jasni pokazatelji koji bi ukazivali na to da reguliranost tržišta rada, odnosno njegova „rigidnost“ uzrokuje nisku stopu zaposlenosti, odnosno visoku nezaposlenost. Prema protivnicima fleksibilizacije tržišta rada, odgovornost za nepovoljnu situaciju što se tiče broja slobodnih radnih mjesta valja tražiti u restriktivnim makroekonomskim politikama, odnosno monetarnoj i fiskalnoj politici, a ne visokoj razini radničkih prava i zaštite.

\section{Socijalno partnerstvo kao dio neoliberalnog diskursa}

Kao što je već istaknuto, na tržištima rada sindikati su shvaćeni kao prepreka djelovanju tržišnih mehanizama, koja onemogućuje učinkovitost u raspodjeli poslova pa posljedično negativno djeluje na produktivnost, ulaganje, inovacije i konkurentnost (McIlroy 2009). Prema neoliberalnim shvaćanjima, sindikati su instrumentom štrajka povećavali plaće na neodržive razine i tako su prema nekim neoliberalnim misliocima doprinijeli inflaciji koja je odigrala 
značajnu ulogu u rastakanju ekonomskog sustava socijalne države; sustava čija ih je težnja ka punoj zaposlenosti zapravo i dovela u poziciju moći (McIlroy 2009).

Institucije tržišta rada koje omogućuju formiranje monopola sindikata imaju moć utjecati na odluke političkih elita, čime mogu utjecati i na stopu inflacije. Što se tiče odnosa između sindikata i pojave inflacija, tu se neoliberalni ekonomisti razilaze u mišljenima. Milton Friedman zastupa tehnokratski pristup prema kojem sindikati ne mogu vršiti utjecaj na inflaciju, koja se može kontrolirati jedino monetarističkom politikom koju provodi država kontrolirajući količinu novca koja je optjecaju. S druge strane, Hayek je smatrao da sindikati svojim pritiscima za povećanjem nadnica sudjeluju u nastanku inflacije. Naime, države su sklone popustiti u svojoj monetarističkoj politici jer je cijena snižavanja nadnica i pregovora sa sindikatima previsoka. Hayek tako ukazuje na središnju slabost kejnzijanske ekonomike kao „kapitulaciju pred moći organiziranog rada i pribjegavanje inflacijskoj fiskalnoj politici ne bi li se smanjila realna vrijednost plaća“ (Jackson 2016: 265). Neoliberalni je pogled na pojavu inflacije u svakom slučaju negirao učinkovitost kejnzijanskih metoda u sprječavanju inflacije i u borbi protiv visoke nezaposlenosti.

Neoliberalnu je percepciju organiziranog rada obilježila karakterom pretežno politička bojazan da sindikati predstavljaju realnu prijetnju autoritetu i legitimitetu države. Moć sindikata u stanju je iskriviti puteve države u njezinom podržavanju i implementaciji previđenih ekonomskih politika. Neoliberali su također smatrali da mnogi radnici individualno, svojom voljom ne pristaju na kolektivne akcije sindikata, već da su na to prisiljeni. Moderni se sindikati u kontekstu neoliberalnog diskursa okarakterizirani kao udruženja prisilnog oblika koja koriste sredstva štrajka, bojkota i drugih oblika kolektivne borbe, ne kao ishod odluke i podrške njihova članstva, nego jednostavno zato što im te mogućnosti pruža radno zakonodavstvo nastalo u okvirima socijalno-demokratske države. Jackson (2016) ustvrđuje da se u toj neoliberalnoj argumentaciji naziru dvostruka mjerila jer se neoliberali ne protive utjecaju koji na državu vrše na primjer poslovne korporacije ili lokalna vlast, koje također znaju pribjegavati iznuđivanju države i koje u tome mogu uživati zakonsku zaštitu. Neoliberali dakle opasnost za autoritet države primarno vide u djelovanju sindikata koji ju osujećuju u ulozi da osigurava nesmetano funkcioniranje slobodnog tržišta. Sindikati koriste legalne instrumente koji su im na raspolaganju ne bi li prinudili državu da djeluje u područjima na kojima bi tržište daleko bolje funkcioniralo kao mehanizam raspodjele i donošenja odluka.

$\mathrm{U}$ tom smislu socijalno partnerstvo ima ulogu smanjiti učestalost $\mathrm{i}$ intenzitet industrijskih akcija te raskinuti s negativnim socijalističkim nasljeđem sindikata, negativnim 
asocijacijama koje sindikate povezuju sa socijalizmom ili komunizmom. U drugim dijelovima kontinentalne Europe kao što su Njemačka, Austrija, Nizozemska, i Francuska, socijalno partnerstvo je pojam koji je omogućio socijalnoj demokraciji da se tijekom hladnog rata distancira od „komunističke“ ideologije klasne borbe. Međutim, pojam socijalnog partnerstva ili socijalnih partnera u sebi sadrži određenu pristranost koja industrijske odnose usmjerava od konflikta ka suradnji te je iz tog razloga sintagma socijalnog partnerstva i socijalnog dijaloga uvijek izazivala određenu sumnju kod ljevice (Hyman 2005).

Mnogi autori, kao na primjer Stanford i Vosko (2004), McIlroy (2009) i Phelan (2007b, 2014), diskurs socijalnog partnerstva smatraju komponentom neoliberalnog diskursa; sofisticiranim mehanizmom neoliberalizma kojim kapital disciplinira i podređuje rad te pacificira sindikate. Dio teoretičara poput na primjer Espinga Andersena (2003) ili Petera Auera (2007) odnos između rada i kapitala koncipiran kroz socijalno partnerstvo ne problematizira kao jednu od taktika koje zagovaratelji fleksibilizacije tržišta rada koriste za provođenje neoliberalnih politika, između ostalog zato jer smatraju da je nekakav oblik partnerstva i konsenzusa dobar i za radnike i za poslodavce. Primjerice Auer (2007) drži da ako socijalno partnerstvo i jest oblik obuzdavanja sindikalnog otpora agendama kapitala, odnosi između rada i kapitala koncipirani kroz socijalni dijalog obilježeni su i velikim dozama konflikata i neslaganja te ustupcima na koje pristaju svi koji u dijalogu sudjeluju. Diskurs socijalnog partnerstva ili socijalnog dijaloga također može predstavljati dio diskursa socijalne države aktivnim uključivanjem sindikata u kreiranju i provođenju politika na tržištu rada, kao i drugih ekonomskih politika.

\section{Neoliberalno preslagivanje kategorija na tř̌ištu rada}

\section{a) Ljudski kapital umjesto rada}

Neoliberalna se doktrina sastojala od prilagođavanja neoklasičnih postulata neoliberalnoj agendi uspostavljanja slobodnog tržišta kao optimalnog oblika regulacije ekonomskih, ali i društvenih odnosa. Većina je neoliberalnih teza zapravo preuzeta iz klasične i neoklasične ekonomike, ali postoji jedna teorija koja je originalna i pripada specifično neoliberalizmu, odnosno neoliberalnom diskursu. Neoliberalnom diskursu svojstveno je zamagljivanje razlikovanja rada od kapitala, kada se u jednom trenutku, rad počeo opisivati $u$ terminima takozvanog ljudskog kapitala. Foucault (2008) je u svojim predavanjima o neoliberalizmu prikazao način na koji je neoliberalna misao u ekonomski diskurs uvela jedno potpuno novo i specifično shvaćanje ljudskog rada. Teorija ljudskog kapitala uključivala je dva 
različita procesa. Jedan proces je podrazumijevao podvrgavanje dotad neistraženog područja ekonomskoj analizi. Drugi proces odnosio se na ekonomsko shvaćanje jedne oblasti društvenog života koja do tada nije bila razmatrana u ekonomskim terminima. Američki neoliberalni mislioci su smatrali da u klasičnoj političkoj ekonomiji ne postoji zadovoljavajuće ekonomsko pojašnjenje rada kao jedne od triju komponenata proizvodnje. Klasični su mislioci, prema neoliberalima, rad svodili na vremensku varijablu, dok je u Keynesovoj analizi rad opisan kao faktor proizvodnje koji ovisi o dovoljno visokoj stopi ulaganja. Neoliberalni su teoretičari tako u područje ekonomske analize uklopili rad opisavši ga u terminima (ljudskog) kapitala pri čemu su u odnosu na klasične ekonomiste redefinirali epistemološki okvir ekonomske analize. Iz neoliberalne perspektive, ekonomska se analiza bavi ljudskim ponašanjem koje raspodjeljuje sredstva ne bi li postiglo konkurirajuće, odnosno alternativne ciljeve koji se međusobno isključuju. Predmet je ekonomske analize dakle način na koji pojedinci donose izbor za koje će ciljeve upotrijebiti ograničena sredstva koja su im na raspolaganju. Ako ovakvu usmjerenost ekonomske analize primijenimo u slučaju rada, Foucault (2008) kaže da ta ekonomska analiza onda znači analizu načina na koji pojedinac tijekom rada koristi njemu dostupna sredstva. U neoliberalnoj se misli smatra da se ulaganje u znanje i vještine radnika može smatrati kapitalnom investicijom koja bi u budućnosti trebala proizvoditi veći dotok prihoda pojedincu od njegova rada (Jackson 2016: 267). Naime, to je investiranje slično kao i investiranje tradicionalno shvaćenog vlasnika kapitala u strojeve ili opremu. Jackson (2016) smatra da je ovakva koncepcija rada u kontekstu socijalne države mogla podupirati zahtjeve za većim ulaganjima u obrazovanje i zdravstvo. Međutim, rad kao ljudski kapital češće se u diskursu koristio kao racionalizacija za ostvarivanje određenih, specifično neoliberalnih ciljeva. Pa je tako u svojoj analizi neoliberalizma, Foucault opisao način na koji je pojedinac prezentiran u neoliberalnom diskursu ne kao radnik, već kao poduzetnik čiji je proizvod on sam, odnosno njegove sposobnosti i vještine koje prodaje na tržištu rada. Kroz ovakvo se shvaćanje pojedinca kao poduzetnika sebe sama, ističe imperativ konkurentnosti na tržištu rada pri čemu nekadradnici-sada-poduzetnici ulažu u sebe ne bi li ostvarili prednost na tržištu u odnosu na druge radnike. U tom se slučaju solidarnost između radnika i mogućnost njihova udruživanja u sindikate zamjenjuje konstantnim međusobnim natjecanjem u nastojanju da se poveća vrijednost onoga što nude na tržištu. U eri neoliberalizma, prevladavajući neoliberalni governmentalitet je obilježen jezikom kapitala i natjecanja, a sve su oblasti života podređene imperativu povećanja prihoda na tržištu rada ulaganjem i marketingom vještina i sposobnosti radnika. „Međutim, možda je najradikalnija implikacija teorije ljudskog kapitala ta da su kategorija rada, i s njome povezane ideje klase, potpuno izbačene iz društvene analize 
proširivanjem koncepta 'kapitala' koji onda u sebe apsorbira same ekonomske interese koji bi mu se trebali suprotstavljati“ (Jackson 2016: 267).

\section{b) Radnici kao proizvođači na tržištu}

Prema neoliberalnoj doktrini Miltona Friedmana ekonomski su akteri predstavljeni kao pripadnici jedne od dviju kategorija: proizvođača i potrošača. Prema neoliberalnim teoretičarima važno je postaviti imperativ zaštite interesa potrošača i to iz nekoliko razloga. Prvi je taj što se zaštitom interesa potrošača, potrošač stavlja u središte ekonomskih procesa čime se osnažuje temeljni preduvjet i temeljna zadaća učinkovitog ekonomskog poretka, a to je zaštita individualnih sloboda i facilitacija funkcioniranja slobodnog tržišta. Naime, proizvođači imaju prednost u odnosu na potrošače s obzirom na to da imaju mogućnost lakše se organizirati oko zajedničkih ciljeva te na taj način ostvarivati svoje interese koji su različiti, odnosno suprotni od interesa potrošača. Jackson (2016) ističe kako je u neoliberalnoj teoriji čikaške škole interes potrošača predstavljen kao javni interes, a zadaća je danog ekonomskog poretka da ustraje u nastojanjima da zaštiti interese potrošača. Naime, interes potrošača, budući da je za neoliberale istovjetan s javnim interesom, vrlo je teško organizirati jer su potrošači raspršena i velika skupina koja vrlo teško adekvatno artikulira vlastiti interes, dok su s druge strane proizvođači dobro organizirani i sposobni svojim koordiniranim naporima izvući višestruke koristi na štetu potrošača. Posebni interesi dobro organiziranih proizvođača će tako uvijek prevladati nad raspršenim i prolaznim interesima potrošača. Jackson (2016) ističe neoliberalnu distinkciju između proizvođača i potrošača te naglašavanje neravnoteže moći koja vlada između njih, kao važne za shvaćanje neoliberalne percepcije sindikata i tržišta rada. Naime, u kontekstu podjele aktera na proizvođače i potrošače, sindikati i radnici spadaju u kategoriju proizvođača na tržištu rada. I iako su raniji ekonomisti, poput Mancura Olsona, u kontekstu teorije javnog izbora, smatrali da su za gospodarski rast jednako štetne velike kompanije i sindikati, Jackson (2016) navodi da su nakon 1960-ih godina neoliberali usredotočili svoje kritike u kontekstu štetnih interesa proizvođača ponajprije na organizirani rad. Neoliberalna je vizija liberalnog društva obuhvaćala stanje u kojem ,pojedinci mogu ostvarivati svoju slobodu kao potrošači, birajući između niza roba i životnih stilova koje nudi tržišna ekonomija“ (Jackson 2016: 268). Međutim, interese radnika, kao proizvođača valja staviti pod kontrolu kako se oni ne bi ostvarivali na štetu potrošača. Radnike se stavlja pod kontrolu uspostavljanjem stroge organizacijske hijerarhije na radnome mjestu. Pred pojedinca kao radnika postavljena su samo dva ishoda koja može uzeti u obzir kao mogućnosti na tržištu rada. Prvi je izbor da prihvati ponudu posla koji mu daje poslodavac, a drugi je da otkaže ugovor o radu na postojećem poslu 
i krene u potragu za novim poslom. Odbiti ili prihvatiti raditi određeni posao u neoliberalnoj je misli centralna ideja položaja radnika na tržištu rada kako ga vide neoliberali (Jackson 2016; Ciepley 2004).

Radnici su u neoliberalnim shvaćanjima fleksibilnosti tržišta rada, dužni preuzimati odgovornost za gubitak posla ili smanjivanje materijalnih kompenzacija, i to ulaganjem u svoje vještine i obrazovanje koje treba oblikovati prema očekivanim potrebama poslovnog sektora (Stanford i Vosko 2004). Dakle, zagovornici fleksibilnosti jednim od njezinih pozitivnih učinaka smatraju poticanje radnika da ulažu često vlastita novčana sredstva i vrijeme na stjecanje kvalifikacija koja im mogu omogućiti bolju poziciju na tržištu rada, što se zapravo smatra ulaganjem u svoje vještina kao u ljudski kapital (Foucault 2008, Jackson 2016). 


\section{FLEKSIBILIZACIJA TRŽIŠTA RADA U HRVATSKOJ}

Fleksibilizacija tržišta rada je u svojim začecima bila dijelom neoliberalnog paketa politika koji se skraćeno naziva DLP agendom, odnosno politikama deregulacije, liberalizacije i privatizacije. U svjetskim je razmjerima proces deregulacije tržišta rada s ciljem fleksibilizacije, odnosno smanjivanja cijene rada pokrenut u jeku krize i propadanja socijalne države. Tijekom 1970-ih i 1980-ih godina, fleksibilizacija tržišta rada s ciljem smanjivanja snage organiziranog rada te pritiskom na nadnice predstavljala je neoliberalni odgovor na naftnu krizu te posljedično i na pojavu stagflacije, odnosno porast stope nezaposlenosti kao i rastuću stopu inflacije. Od tada do danas nisu stali neoliberalni pritisci za deregulacijom tržišta rada kao dio preporuka koje bi trebale sačinjavati odgovor na svaku gospodarsku krizu od propasti kejnzijanskog režima akumulacije 1970-ih godina do danas.

U kontekstu Hrvatske Kulušić (2009), prema Gotovac (2003) razlikuje tri faze kroz koje se provodila fleksibilizacija tržišta rada deregulacijom, od kojih su prve dvije faze bile povezane izravno s neoliberalnim pritiscima za provođenjem politika deregulacije, privatizacije i fleksibilizacije; dok kvalitativno razlikuje treću fazu u koju su bile uključene i zemlje u tranziciji kojima pripada i Hrvatska od prve dvije neoliberalno motivirane faze.

„Fleksibilizacija je u svojoj početnoj i srednjoj fazi, tijekom sedamdesetih i osamdesetih godina prošlog stoljeća blisko povezana $\mathrm{s}$ ekonomskim neoliberalizmom koji se javlja kao odgovor na rast cijena energenata, rast inflacije, visoka vanjska dugovanja te nezadovoljavajuća ekonomska kretanja. Istodobno, ona je značajnim dijelom predstavljala i odgovor poslodavaca na naglašeno jačanje sindikata u prethodnom razdoblju. Iako je danas sasvim drugačije uvjetovana, činjenica povijesne povezanosti s neoliberalizmom te određeni protusindikalni sadržaji utjecali su na to da se sindikati gotovo u pravilu protive zahtjevima i zbog najmanjeg stupnja fleksibilizacije, kako to ističe Gotovac sublimirajući javne istupe sindikalnih čelnika u Republici Hrvatskoj““ (Kulušić 2009: 44).

Prema Kulušić (2009) treća faza fleksibilizacije kojom su zahvaćene i tranzicijske zemlje poput Hrvatske, nije povezana s neoliberalizmom već se na neki način razlikuje od prve dvije faze time što predstavlja odgovor na prilagodbu globalizaciji i zajedničkim tržištima pri čemu se naglašava mogućnost prilagodbe nacionalnih kompanija globalnoj konkurenciji u organizaciji rada: „organizacija radnih procesa i poslovno upravljanje doživljavaju velik napredak: tehnike insourcinga i outsorcinga, suradnja radnika i uprava u sklopu, ,nove ekonomije“ imaju značajne 
posljedice na konkurentnost poduzeća, a konkurentnost postaje dominantnim mjerilom uspješnosti““ (Kulušić 2009: 46). Kulušić također navodi i zahtjeve Međunarodne organizacije rada koja zastupa stajalište da regulaciju tržišta rada treba prilagoditi modernim kretanjima u razvoju tehnologije, zatim demografske promjene koje se odnose na emancipaciju žena i sve veće uključivanje žena na tržište rada što bi trebalo predstavljati neku vrstu prilagodbe regulacije tržišta rada potrebama samih radnika, iako je u realnosti prema nekim istraživanjima to manje vjerojatno (Zeytinoglu 2005). Treća je faza povezana i s izdavanjem OECD-ove publikacije pod nazivom Jobs Study koja se sastoji do skupa preporuka o politikama na tržištu rada s naglaskom na potrebu deregulacije tržišta rada po uzoru na anglosaksonske sustave regulacije, osobito vrlo liberalnog sustava karakterističnog za Sjedinjene Američke Države, kako bi se potaknulo zapošljavanje u europskim zemljama i zemljama Europske unije.

Proces fleksibilizacije tržišta rada u Hrvatskoj povezan je s deregulacijom tržišta rada koja se velikim dijelom zasniva na izmjenama Zakona o radu kao „općeg i temeljnog propisa radnoga i s njime povezanog socijalnog prava u Republici Hrvatskoj“ (Kulušić 2009: 266). Osim spomenutog zakona, radna su prava, kao i druga prava povezana sa socijalnom zaštitom, uređena i posebnim zakonima kao što su Zakon o doprinosima, Zakon o zdravstvenom osiguranju, Zakon o profesionalnoj rehabilitaciji i zapošljavanju osoba s invaliditetom, Zakon o mirovinskom osiguranju, Zakon o obveznim odnosima, Zakon o zaštiti na radu, Zakon o državnom inspektoratu, Zakon o tržištu rada, Zakon o reprezentativnosti udruga poslodavaca i sindikata i drugi. Iz pravne perspektive, Kulušić (2009) ukazuje na problem nekonzistentnosti između pojedinih zakona koji su spomenuti, kao i nedostatak normiranosti nekih pitanja koja su povezana s pitanjima koja se odnose na fleksibilnost tržišta rada. Prvi je Zakon o radu iz 1995. godine, u odnosu na naslijeđeni Zakon o radnim odnosima iz doba Jugoslavije, donio nekoliko izmjena. Tim je zakonom statusni radni odnos pretvoren u ugovorni odnos između radnika i poslodavca s time da su postojala ograničenja u ugovaranju u onim dijelovima koji se odnose na garanciju prava radnika i posebne kategorije radnika. Zakonom o radu iz 1995. godine nastojalo se ostvariti maksimalnu slobodu udruživanja te ,jedinstveno uređenje radnih odnosa neovisno o vlasničkopravnom statusu poslodavaca“ (Kulušić 2009). Prvi je Zakon o radu iz 1995. godine, po svom sadržaju, odnosno rješenjima bio uvelike utemeljen na njemačkom zakonskom uređenju radnih odnosa. Bagić (2010) opisuje kako su sindikalni čelnici bili zadovoljni razinom radnih zaštita osiguranima u prvoj inačici Zakona o radu te ustvrđuje da činjenica da su sve izmjene Zakona o radu nakon toga išle u smjeru fleksibilizacije tržišta rada kao smanjivanja zaštite radnika upućuje na visoku razinu zaštite koja je bila osigurana 
1995. godine, osobito u aspektu zaštite radnika od otkaza. Zakon o radu je od 1995. godine pa sve do donošenja drugog Zakona o radu 2003. godine bio podvrgnut izmjenama četiri puta.

Intervencijama u prvi Zakon o radu došlo je do promjena koje su se odnosile na opseg prava radnika, sadržaj radnog odnosa, sklapanje ugovora o radu, kada je riječ o individualnim radnim odnosima, a na području kolektivnih radnih odnosa redefinirani su opravdani razlozi za štrajk, zaštita predstavnika radnika i slično. Intervencijama u Zakon o radu iz 1995. godine uveli su se fleksibilni, atipični oblici rada na tržište rada, smanjilo se trajanje otkaznih rokova te su se postupno smanjivale visine iznosa otpremnine.

Zapravo je donošenjem drugog Zakona o radu započet proces deregulacije tržišta rada s ciljem povećanja smanjenja cijene rada u Hrvatskoj. Prve izmjene Zakona o radu iz 2003. godine provodila je socijalno-demokratska vlada, odnosno koalicijska vlada pod vodstvom SDP-a, a cilj te reforme bila je fleksibilizacija tržišta rada. Te su izmjene predstavljale provođenje naputaka koje je Vlada dobila od Međunarodnog monetarnog fonda i Svjetske banke kao preporuka u sklopu stand by aranžmana, ali je također bila potaknuta i lobiranjem poslodavaca te htijenjima samih članova Vlade (Bagić 2010). Sindikati su se opirali spomenutim izmjenama, osobito kada su u pitanju bili smanjivanje visine otpremnina i skraćivanje otkaznog roka. Bagić (2010) ističe kako je jedno od prijepornih pitanja oko kojih industrijski akteri ne uspijevaju uspostaviti odnos suradnje, odnosno socijalnog partnerstva upravo fleksibilizacija tržišta rada. Tako je pri pokušajima uvođenja primata tržišnih odnosa u radne odnose deregulacijom tržišta rada, došlo do neslaganja između industrijskih aktera (vlade, poslodavaca i sindikata), pa su planovi za fleksibilizaciju tržišta rada deregulacijom predviđeni izmjenama Zakona o radu 2003. i 2009. godine redovito završavali raspadom tripartitnog dijaloga i jednostranim donošenjem odluka Vlade o specifičnostima regulacije na spomenutom području. Zbog nemogućnosti iznalaženja kompromisnog rješenja koje bi zadovoljio sve strane koje sudjeluju u tripartitnom dijalogu, Vlada je spomenute izmjene u pojedinim slučajevima donosila jednostrano.

Promjene Zakona o radu iz 2003. godine na nekoliko su razina predstavljale povećanje stupnja fleksibilnosti tržišta rada, što je podrazumijevalo i smanjivanja zaštite radnika. Cilj tadašnjih izmjena, na preporuku MMF-a i Svjetske banke, bilo je povećanje fleksibilnosti tržišta rada kako bi se smanjio indeks radne zaštite, odnosno mjera kojom OECD ocjenjuje stupanj fleksibilnosti tržišta rada pojedinih država. Prije spomenutih izmjena međunarodni indeks zakonske zaštite zaposlenja ili EPL indeks (eng. employment protection legislation) iznosio je 
3,58 što se u kontekstu drugih zemalja smatra visokim te Hrvatsku kvalificira kao zemlju s „rigidnim“ radnim zakonodavstvom.

Kulušić (2009) navodi da je dio izmjena Zakona o radu s ciljem postizanja fleksibilnosti na tržištu rada bilo ostvarivanje fleksibilnosti zapošljavanja. Fleksibilnost zapošljavanja odnosi se na „lakoću zapošljavanja koja se očituje u stupnju lakoće pristupa i uporabe fleksibilnih oblika zapošljavanja, kao što su ugovor o radu na određeno vrijeme, ugovor o radu s nepunim radnim vremenom (part-time) i ugovor o radu s agencijom za posredovanje u zapošljavanju“ (Kulušić 2009: 268). Prema ovoj se definiciji može zaključiti da fleksibilnost zapošljavanja kao lakoća zapošljavanja pretpostavlja ostvarivanje zaposlenosti na temelju uvođenja oblika rada koji se ne odnose na zaposlenost u standardnom obliku redovitog ugovora o radu na neodređeno vrijeme s punim radnim vremenom. Dakle, izmjenama Zakona o radu iz 2003. godine cilj je bilo uvođenje mogućnosti osnivanja agencija za posredovanje u zapošljavanju, što se smatralo mjerom fleksibilnosti koja omogućuje lakše zapošljavanje.

Druga mjera stupnja fleksibiliziranosti tržišta rada koja čini dio OECD-ova indeksa zakonske zaštite zaposlenja jest lakoća otpuštanja, a ona se mjeri pomoću indikatora koji obuhvaćaju pojednostavljivanje postupaka otpuštanja te smanjenje troškova otpuštanja. $\mathrm{Na}$ ovom su području također smanjene zaštite radnika i to pojednostavljivanjem procedure kolektivnih otpuštanja, smanjivanjem otpremnina i skraćivanjem otkaznih rokova. Na području kolektivnog otpuštanja, izmjene su obuhvaćale postupak otkazivanja kada je riječ o 20 ili više radnika, pri čemu poslodavac mora izraditi program zbrinjavanja viška radnika $\mathrm{i}$ to $\mathrm{u}$ konzultacijama s regionalnim zavodom za zapošljavanje i radničkim vijećem. Navedene su promjene predstavljale olakšanje procedure otpuštanja u odnosu na prethodna zakonska rješenja (Kulušić 2009). Osim kolektivnog otpuštanja, promijenjene su odredbe o proceduri trajanja otkaznog roka te visini otpremnina koje su smanjene. U drugom Zakonu o radu otpremnine su smanjene s prethodnog zakonski određenog iznosa od polovice prosječne plaće po godini radnog staža kod istog poslodavca na jednu trećinu prosječne plaće, s time da se taj omjer u novom Zakonu odnosio na bruto plaću s obzirom na ranije određenje neto plaće. Ovom je odredbom radnicima smanjen iznos otpremnina za otprilike 17\%, s time da su ovim izmjenama gubici radnika s nižim primanjima bili mnogo veći zbog manje razlike između njihove neto i bruto plaće. Radnici su također pretrpjeli materijalni gubitak zbog uvođenja gornje granice otpremnina na 6 prosječnih plaća, čime su oštećeni radnici s duljim radnim stažom, s obzirom na to da u prijašnjem Zakonu o radu spomenuto ograničenje nije postojalo. Kada su u pitanju otkazni rokovi, došlo je do skraćivanja njihova trajanja kod otkaza na 
inicijativu poslodavca s maksimalnih šest mjeseci na maksimalna tri mjeseca kada je radnik zaposlen kod istog poslodavca minimalno 20 godina bez prekida te skraćivanja trajanja otkaznog roka kod zaposlenika s kraćim radnim stažem. Također je olakšan postupak otkazivanja ugovora o radu za poslodavce s najviše 20 zaposlenika, dok se jednostavnija procedura otkazivanja do tada primjenjivala na male poduzetnike koji su zapošljavali do 10 radnika (Bagić 2010). Navedene promjene koje se odnose na povećanje stupnja lakoće otkazivanja ugovora o radu za sindikate su bili najsporniji dijelovi reforme radnog zakonodavstva 2003. godine, a to su ujedno i promjene koje se odnose na indikatore koji određuju OECD-ov indeks zakonske zaštite radnika, pa su u tom smislu sindikati točno detektirali promjene koje utječu na službeno izmjereni stupanj fleksibiliziranosti tržišta rada (Matković i Biondić 2003).

Prije reforme radnog zakonodavstva koja se dogodila 2003. godine, EPL indeks Hrvatske iznosio je 3.58 bodova od maksimalnih 6 bodova što je Hrvatsku, prema kriterijima OECD-a, svrstavalo u zemlje s visokim stupnjem zakonske zaštite radnika, odnosno sa stupnjem regulacije zbog kojeg se hrvatsko tržište rada moglo smatrati jednim od najrigidnijih u Europi. Matković i Biondić (2003) nastojali su pokazati kako je reforma zakonodavstva iz 2003. godine utjecala na smanjivanje EPL indeksa za Hrvatsku, pri čemu su se ogradili od toga u kojoj mjeri EPL indeks zaista odražava fleksibilnost tržišta rada, navodeći kako „radno zakonodavstvo poznaje brojne i vrlo raznolike instrumente zaštite zaposlenja koje je teško uspoređivati, a gotovo nemoguće kvantificirati bez gubitka sadržaja. Svojevrsnu standardiziranu jezgru uobičajenih i usporedivih indikatora zakonske zaštite zaposlenja čini OECD-ov EPL (eng. Employment Protection Legislation) indeks sastavljen 1999. godine (OECD, 1999)“ (Matković i Biondić 2003: 516). Razlaganjem indeksa na tri komponente: stalno zapošljavanje, privremeno zapošljavanje i kolektivni otkazi, gore spomenuti autori nastoje prikazati promjenu radnog zakonodavstva u Hrvatskoj te ju prikazati u usporedbi s drugim zemljama. Na području stalnog zapošljavanja došlo je do promjena stupnja zaštite u pojedinačnim otkazima, i to, kao što je već ranije navedeno, u regulaciji duljine otkaznih rokova i visine otpremnina. promjene na to području izmijenila su pokazatelj stupnja radnih zaštita stalnog zaposlenja s 2,76 na 2,59. Do najveće je promjene, odnosno smanjenja pokazatelja zaštite zaposlenja došlo u komponenti koja se odnosi na privremeno zapošljavanje, i to uvođenjem jednog noviteta, a to je regulacija agencija za privremeno zapošljavanje. Kada se radi o agencijama, u hrvatskim zakonima ne postoji ograničenje vrsti poslova koje agencija smije obavljati, međutim uvedena su ograničenja o trajanju zaposlenja kod jednog te istog 
poslodavca i to na 12 mjeseci, dok nema ograničenja uzastopnim ugovorima. Upravo je uvođenje instituta agencija za privremeno zapošljavanje tada predstavljalo najveći doprinos smanjenju EPL indeksa. Što se tiče kolektivnih otkaza, došlo je do promjene definicije kolektivnog otkaza pri čemu je prethodni ZOR kolektivni otkaz ograničavao na 5 otkaza tijekom 6 mjeseci, dok je u tadašnjim izmjenama ZOR-a došlo do promjene na 20 ugovora o radu unutar 90 dana. Ovim se izmjenama EPL indeks smanjio za 23\%, odnosno za 0,82 boda, odnosno s 3,58 na 2,76 bodova (Matković i Biondić 2003).

Vlada, sindikati i poslodavci o navedenim su izmjenama radnog zakonodavstva pregovarali više od dvije godine, točnije od prve polovice 2001. godine, a pregovori su bili popraćeni nastojanjima sindikata da ublaže smanjivanja prava radnika koja su se planirala provoditi navedenim izmjenama. Već su 2001. godine sindikati započeli s prosvjednim aktivnostima ne bi li izvršili javni pritisak na tadašnju Vladu da smanji intenzitet predloženih izmjena koje su išle u smjeru fleksibilizacije, odnosno smanjivanja indeksa zakonski određene radne zaštite. Na Trgu sv. Marka te su godine održana dva prosvjeda, koja su između ostalog imala za cilj ukazati na sindikalne primjedbe i zahtjeve povezane s prijedlogom ZOR-a. Savez samostalnih sindikata Hrvatske svoje je nezadovoljstvo smjerom kojim se kreće Vlada kada je u pitanju zakonska zaštita radnika iskazao napuštanjem Sporazuma „Partnerstvo za razvoj“ 2002. godine. Te je godine održana i prosvjedna proslava Praznika rada kada su sindikati kritizirali članove Vlade zbog spomenutih izmjena. Bagić (2010: 254) opisuje vrhunac intenziteta sindikalnih aktivnosti usmjerenih protiv izmjena ZOR-a tijekom 2003. godine. Prvo je organiziran Svesindikalni sabor prosvjednog naziva „Mijenjajte sebe, a ne Zakon o radu“. $\mathrm{Na}$ tom su saboru sve sindikalne središnjice usvojile deklaraciju, da bi nakon toga sindikati održali prosvjed na kojem se okupilo otprilike 6000 sindikalnih povjerenika ispred zgrade Vlade. Drugi korak koji su sindikati namjeravali poduzeti bilo je organiziranje općeg štrajka, za što su nastojali organizirati referendum o njegovoj provedbi, međutim, zbog neslaganja između čelnika pojedinih sindikalnih središnjica taj referendum nije proveden. Daljnje su prosvjedne aktivnosti sindikati organizirali razjedinjeno, pri čemu su neki od sindikata organizirali prosvjede pred Saborom tijekom izglasavanja Zakona o radu.

Prema procjeni Kulušić (2009), u Zakonu o radu iz 2003. godine neka rješenja nisu bila dobro zamišljena, pa se tako studentski ugovori te ugovori o radu i ugovori o djelu nisu smatrali ugovorima o radu te nisu spadali pod regulaciju spomenutog zakona. Kulušić također ističe da su postojale prepreke u primjeni tada uspostavljenih fleksibilnih instituta na tržištu rada kao što su smanjivanje visine otpremnina i smanjivanje otkaznih rokova te rada s nepunim radnim 
vremenom. Kulušić (2009) ustvrđuje kako su se oko nastojanja da se pomoću drugog Zakona o radu fleksibiliziraju radni odnosi u Hrvatskoj, vodili mukotrpni pregovori između industrijskih aktera pri čemu su sindikati očekivano nastojali održati što je veći stupanj zaštite radnike, dok su poslodavci tražili labavljenje uspostavljene razine radnih zaštita i to pozivajući se na određene procjene, kao što je usporedba EPL indeksa koji je spomenutim izmjenama s 3,58 boda smanjen na 2,76 bodova. Poslodavci i analitičari su uspoređujući EPL indeks hrvatskog radnog zakonodavstva s onima drugih zemalja, zaključili kako je tadašnje hrvatsko radno zakonodavstvo bilo jedno od najrigidnijih u Europi. EPL indeks je poslužio kao prilog argumentaciji koja se zalagala za deregulaciju hrvatskog tržišta rada.

Nakon drugog Zakona o radu iz 2003. godine, 2014. godine donesen je i treći Zakon o radu. Vlada Republike Hrvatske izmijenila je drugi Zakon o radu 2013. godine i to s ciljem usklađivanja hrvatske radne regulative s europskim radnim zakonodavstvom, dok je 15. srpnja 2014. u Hrvatskom saboru izglasan novi, restrukturirani i prema EPL indeksu kao mjerodavnom pokazatelju manje ,rigidan“ Zakon o radu. Što se tiče karaktera politika čije je slijeđenje dovelo do posljednjih promjena Zakona o radu u smjeru deregulacije, odnosno fleksibilizacije tržišta rada, sam ministar rada Mirando Mrsić, u predgovoru je izdanja knjige Zakon o radu s komentarima i tumačenjima, u izdanju Tim Pressa iz 2014. godine, napisao:

„Zakon o radu počinje se primjenjivati u uvjetima potrebe saniranja teških posljedica koje je na tržište rada ostavila gospodarska i financijska kriza.

U Hrvatskoj je od 2008. godine izgubljeno više od 200000 radnih mjesta, šest godina suočavamo se s gospodarskom krizom, proračunski deficit je iz godine $u$ godinu veći i zahtijeva preispitivanje rashoda javnog sektora a javni dug je premašio $60 \%$ ukupnog društvenog proizvoda. Porezni sustav traži reformu. Globalno gospodarstvo zahtijeva daljnju deregulaciju, liberalizaciju i privatizaciju. Ne treba pri tome zaboraviti da je od 1. srpnja 2013, godine Republika Hrvatska punopravna članica Europske unije te da mora poštovati obveze zacrtane programskim dokumentima Europske unije kao što je Strategija Europa 2020. odnosno obveze Europskog semestra.

Loše stanje u gospodarstvu te prekomjerni deficit bili su podloga za pokretanje procedure prekomjernog deficita, što od države članice iziskuje dodatne napore u provedbi reformi usmjerene na podizanje konkurentnosti i produktivnosti te na stvaranje novih radnih mjesta i poticanje zapošljavanja.“ 
Reforme hrvatskog tržišta rada započele su i na poticaj međunarodnih institucija kao što su Svjetska banka, Međunarodni monetarni fond te Europska unija i to s preporukama da se poveća fleksibilnost tržišta rada čime bi se trebao smanjiti EPL indeks, a time trebala poboljšati pozicija Hrvatske na ljestvicama konkurentnosti (Bagić 2010). Argumenti za provođenje deregulacije tržišta rada uglavnom se temelje na pretpostavci povezanosti stupnja „rigidnosti“, odnosno reguliranosti tržišta rada s lošom situacijom kada je u pitanju agregatna nezaposlenost, odnosno zaposlenost. Kao što je i vidljivo iz gornjeg citata bivšeg ministra rada i mirovinskog sustava, spominju se i tvrdnje da reforme radnog zakonodavstva u smjeru deregulacije stvaraju uvjete za smanjivanje nezaposlenosti, odnosno za otvaranje radnih mjesta. Međutim, valja istaknuti da najveći dio istraživanja koja su provođena o povezanosti fleksibilnosti tržišta rada i (ne)zaposlenosti ne daju jasno vidljive indikatore kojima bi se mogao utvrditi utjecaj deregulacije na zapošljavanje. Kulušić (2009), iako u svojoj knjizi zauzima pozitivan stav prema fleksibilnosti i pravnom uređenju tržišta rada prema (neo)liberalnim načelima, ukazuje na to da nije utvrđeno da rigidna regulacija tržišta rada stvara nepovoljnu situaciju kada je riječ o zapošljavanju. Što se tiče EPL indeksa, Boeri i Van Ours (2008) opisuju teorijsku pozadinu EPL indeksa, koja predviđa da bi zemlje sa „strožim“ EPL indeksom trebale bilježiti manji obrtaj radne snage (ukupnost zapošljavanja i otpuštanja), kao i obrtaj poslova (sveukupno otvaranje i gašenje radnih mjesta), međutim empirijska istraživanja i usporedbe između država s različitim EPL indeksima pokazuju da praksa nije usklađena s teorijom. Ono što se može potvrditi jest da visoki EPL utječe na strukturu zaposlenosti i nezaposlenosti, odnosno dovodi se u vezu s većom stopom nezaposlenosti među mladima i većom zaposlenosti u skupini radnika srednjih godina, što je u skladu i s teorijom „,insidera“ i „outsidera“. Gosta Esping Andersen i Regini (2000) također navode kako deregulacija tržišta rada, odnosno stupanj reguliranosti tržišta rada nemaju utjecaja na agregatnu nezaposlenost i zaposlenost, već utječu na strukturu nezaposlenih, pa tako određene institucije tržišta rada povećavaju vjerojatnost da će mladi, niskokvalificirani i žene biti nezaposleni. Ciljanom deregulacijom određenih aspekata tržišta rada, koje bi trebale pratiti i mjere povećanja socijalne sigurnosti i uvođenja prilagođene regulacije, može se djelovati na to da se nezaposlenost ne koncentrira većim dijelom na navedenim skupinama. S time da valja biti svjestan da deregulacija sama po sebi neće stvoriti nova radna mjesta, a ukoliko nije pažljivo izvedena može dovesti do povećanja udjela poslova koji su niske kvalitete, kao što je to slučaj u Sjedinjenim Američkim Državama, kao što uostalom pokazuju i analize samog OECD-a (Deakin i Wilkinson 1994). 


\section{CILJ ISTRAŽIVANJA I ISTRAŽIVAČKA PITANJA}

U doktorskom radu će se istražiti javni diskurs o fleksibilizaciji tržišta rada u Hrvatskoj na temelju analize članaka dnevnih novina. Cilj je rada otkrivanje poretka diskursa koji tvore javni diskurs o fleksibilizaciji, s posebnim naglaskom na neoliberalnom diskursu te oponirajućim diskursima koji problematiziraju karakter i neoliberalnu interpretaciju fleksibilizacije tržišta rada. U radu će se nastojati ustanoviti kako diskurs o fleksibilizaciji artikulira odnose moći društvenih aktera koji u njemu sudjeluju te povezati otkriveni poredak diskursa s javnim politikama na tržištu rada u Republici Hrvatskoj.

Rad je vođen sljedećim istraživačkim pitanjima:

1. Dominira li u hrvatskom javnom diskursu o fleksibilizaciji tržišta rada neoliberalni diskurs?

2. Mogu li se u hrvatskom javnom diskursu o fleksibilizaciji tržišta rada prepoznati akteri koji doprinose dominaciji neoliberalnog diskursa?

3. Je li dominacija neoliberalnog diskursa u javnom diskursu o fleksibilizaciji tržišta rada povezana s provođenjem javnih politika na tržištu? 


\section{PRIKUPLJANJE I OBRADA MATERIJALA ZA ANALIZU}

Materijal za analizu su novinski tekstovi iz nacionalnih dnevnih listova Jutarnjeg i Večernjeg lista, koji su izdvojeni iz perioda javne rasprave i pregovora oko izmjena Zakona o radu i to od 1. 1. 2013. do donošenja zakona 15. 7. 2014. godine na temelju ključnih riječi „fleksibilizacija tržišta rada“ i „Zakon o radu“. S obzirom na same ciljeve kvalitativnih istraživanja te općenite preporuke o uzorcima u kvalitativnim istraživanjima, a pogotovo doktorskim istraživanjima koja imaju značajna vremenska i financijska ograničenja (Mason, 2010), uzorak je velik. S ciljem olakšavanja diskurzivne analize ovako velikog broja tekstova, upotrijebljen je softver za kvalitativnu analizu podataka MAXQDA ne bi li se provela pretraga tekstova prema ključnim riječima ili sintagmama proizašlima iz početne analize određenog manjeg broja članaka.

Materijal je naručen i kupljen od kompanije Presscut koja se bavi press clippingom, a sastojao se od 183 skenirane datoteke koje su isporučene kao skenirane slike novinskih tekstova u PDF formatu. S obzirom na to da rad sa skeniranim novinskim tekstovima ima određena ograničenja kada se radi o analizi teksta u programu MAXQDA jer onemogućava automatsko pretraživanje i uvid u brojnost pojedinih leksičkih jedinica, valjalo je naći način kako pretvoriti skenirane tekstove u PDF formatu u pretražljive tekstualne datoteke. Pokušano je pretvarati skenirane slike u PDF formatu u tekstualni format preko različitih OCR programa (eng. optical character recognition), međutim, veliki broj datoteka bio je loše kvalitete zbog toga što su mnogi novinski tekstovi berliner formata prilagođavani standardnim dimenzijama A4 formata u PDF-u, pa su pojedini prikazi, odnosno slike tiskanih članaka bile izobličene tako da je slova bilo teško očitavati. OCR programi veliki broj njih nisu uspijevali u cijelosti prevoditi u prepoznatljiv tekstualni oblik, ili ono što je bio rezultat konverzije u pretražljivi tekst naprosto nije bilo upotrebljivo zbog neprepoznatljivosti značenjskih jedinica koje su se $u$ transformiranom obliku velikim dijelom sastojale od znakova od kojih mnogi nisu niti bili slova. Nakon toga je započeta aktivnost mrežnog pretraživanje tekstova online izdanja dvaju dnevnika, što je proizvelo relativno povoljne rezultate, jer je ustanovljeno da je više od 50\% tekstova dostupno u online obliku koji je identičan tiskanim izdanjima. Pronađeni su tekstovi preslikani s mrežnih stranica u MS Office program Word. Drugi je dio, dakle zahtijevao očitavanje OCR metodom ili pak zbog lošije kvalitete samih slika, ručno prepisivanje tekstova u program Word. 
Sama obrada formata tekstova, kao i pretraživanje na internetu podrazumijevalo je i upoznavanje s temama samih tekstova. Tada je ustanovljeno da je, za pretraživanje upotrijebljena ključna riječ ,Zakon o radu“, spomenuta u tekstovima koji se ni na koji način ne odnose na fleksibilizaciju, ili pak na vrlo marginalan način. Slijedom tog otkrića smatralo se opravdanim isključiti iz uzorka tekstove koji su nisu bavili temom rasprave o Zakonu o radu u kontekstu fleksibilizacije. Isključeni su se tekstovi bavili, na primjer, referendumom o ustavnoj definiciji braka, izborima intendanata u kazalištima, pojedinačnim i nepovezanim radnim sporovima i štrajkovima (spor između babice i bolnice zbog priziva savjesti, radno vrijeme zagrebačkih asfaltera tijekom ljetnih mjeseci, izgradnja zračne luke u Zagrebu, beneficirani radni staž radnika koji provode razminiranje, štrajkovi liječnika, naknade liječnicima koji su profesori na fakultetima, na primjer) i slično. Program MAXQDA korišten je kako bi se dobila približna slika strukture vokabulara, prevladavajućih tema i aktera u tekstovima, međutim, prisutna su bila i određena ograničenja vezana uz njegovu primjenu. S obzirom na to da se interdiskurzivna analiza pretežito odnosila na analizu argumentacija za ili protiv prijedloga varijanti zakona koje su donosile veću fleksibilizaciju radnih odnosa smanjenjem radnih zaštita, samo pojavljivanje jezičnih jedinica nije značilo i automatsko kodiranje pojedinih argumentacija, iako su pojedine sintagme uzimane u obzir kao pokazatelji da postoji mogućnost da je argumentacija prisutna. Također je bio važniji uvid u jedinice argumentacija i sintagmi koje su iznad razine riječi kao pojedinih jedinica, a samo istraživanje nije niti bilo koncipirano na način da bi se trebalo usredotočiti na pojavljivanje pojedinih riječi u tekstu, već je težište više bio način na koji pojedini akteri shvaćaju određene fenomene, kako ih tumače i upotrebljavaju u vlastitim diskursima. Pomoću programa MAXQDA svejedno je bilo olakšano strukturiranje i sistematiziranje kodiranja, ali temeljitim iščitavanjem svakog pojedinog teksta iz čega je proizašla složena i razgranata kodna shema glavnih tema i podtema utemeljena na analiziranom materijalu (Dodatak 1). Iz kodirane je sheme tema konceptualiziran poredak diskursa prema uočenim argumentacijama povezanima s pojedinim akterima koji ih koriste kao sudionici u javnom diskursu. Mehaničko pretraživanje i analiza leksika nisu sami po sebi bili ključni za istraživanje s obzirom na to da je zbog mogućnosti višeznačnog tumačenja pojedinih riječi i sintagmi u tekstu uvijek teško jednoznačno odrediti i kategorizirati određene izjave na temelju pojavljivanja pojedinačnih riječi, sama odluka o kategorizaciji ne ovisi o programu već o odluci istraživača. Postoje mnogi primjeri kada sami pojedini akteri koriste rječnik primjerice neoliberalnog diskursa svjesno uspostavljajući povezanost određenih termina s neoliberalnom paradigmom koju u diskursu kritiziraju. 
Materijal za analizu javnih politika na tržištu rada je i Zakon o radu, kao temeljni pravni tekst koji određuje radno-pravni sustav u Republici Hrvatskoj, Zakon o posredovanju pri zapošljavanju i pravima za vrijeme nezaposlenosti, Zakon o doprinosima za obvezna osiguranja i Zakon o mirovinskom osiguranju. Također su uključeni izvori za praćenje trendova na tržištu rada, a to su: podaci na stranicama Eurostata, Mjesečni statistički bilten Hrvatskog zavoda za zapošljavanje, Anketa poslodavaca Hrvatskog zavoda za zapošljavanje te Analitički bilten Hrvatskog zavoda za zapošljavanje. Konzultirana su izvješća Svjetske banke. 


\section{OBILJEŽJA JAVNOG DISKURSA O FLEKSIBILIZACIJI TRŽIŠTA RADA U HRVATSKOJ}

\subsection{Uzorak}

Korpus članaka izdvojenih za analizu izabran je na temelju pojavljivanja pojmova „Zakon o radu” ili „fleksibilizacija tržišta rada” pa su osnovne teme u kojima se pojavljuju navedeni pojmovi zapravo teme povezane s fleksibilizacijom tržišta rada, bilo kao podteme ili fleksibilizaciji nadređene teme. Da bi se olakšala diskurzivna analiza većeg broja tekstova korisno je bilo urediti uzorak na način da ga se podijeli na podteme u okviru fleksibilizacije, odnosno liberalizacije radnog zakonodavstva. Ustanovljene podteme su procesi vezani uz tripartitni dijalog, kao i iz njih proizašli odnosi među industrijskim akterima i kolektivna djelovanja sindikata te osvrti na promjene u regulaciji radnih odnosa koje iznose ekonomski i pravni stručnjaci, ali i kolumnisti i novinari specijalizirani za teme iz područja gospodarstva. U uzorku se pojavljuju i članci koji su tematski povezani s fleksibilizacijom tržišta rada na način da je sama fleksibilizacija dio jedne, moglo bi se reći veće i općenitije teme, koja se odnosi na svjetsku gospodarsku krizu, odnosno na ekonomsku krizu koja je u Hrvatskoj u vrijeme donošenja novog Zakona o radu trajala već nekoliko godina. Naime, svi izdvojeni članci povezani s donošenjem novog Zakona, kao i s fleksibilizacijom tržišta rada, proizlaze iz krize hrvatskog gospodarstva, pa se i sama fleksibilizacija navodi kao jedna od mjera, odnosno koraka koje valja napraviti ne bi li se ta kriza i prebrodila. Jedna od najčešćih tema članaka koje se pojavljuju u korpusu jest tema predlaganja reformi za izlazak iz krize koje obuhvaćaju mjere povećanja konkurentnosti i privlačenja stranih ulaganja pri čemu se kao jedan od ključnih čimbenika navodi i fleksibilizacija tržišta rada u Hrvatskoj. Kao akteri koji promiču i pojašnjavaju predložene oblike reformi jesu u najvećem udjelu sami poslodavci, odnosno poduzetnici te znanstvenici i stručnjaci ekonomisti, kao i pojedini političari.

Još jedna podtema koja se također pojavljuje kao izravna posljedica krize je rast broja nezaposlenih u Hrvatskoj, pri čemu se kao izvori navode podaci Državnog zavoda za statistiku i Eurostata. Niska zaposlenost, odnosno visoka nezaposlenost često se dovodi u vezu s tadašnjim postojećim stupnjem fleksibilnosti hrvatskog tržišta rada koji nije dovoljno visok da bi omogućio potrebni, značajniji obujam zapošljavanja.

U korpusu osim članaka u kojima se fleksibilizacija spominje samo kao jedna podtema, nalazimo skupinu članaka koji se bave fleksibilizacijom tržišta rada u užem smislu, odnosno deregulacijom kroz donošenje novog Zakona o radu. U tu temu pripadaju i članci koji se odnose 
na praćenje procesa vezanih uz tripartitni dijalog, odnosno prezentaciju reformi koje je tadašnja Vlada pripremila kao mjere stvaranja uvjeta za izlazak iz krize. U člancima se također iznose planirane mjere koje su tijekom pregovora dogovorene bilo s poslodavcima ili sa sindikatima te reakcija pojedinih industrijskih aktera na njih.

Značajni se dio članaka iz korpusa odnosi na temu prekida pregovora Vlade i sindikata, to jest novinskih tekstova koji prate akcije sindikata i sindikalna nastojanja oko stvaranja pritisaka na Vladu ne bi li se osnažio njihov pregovarački položaj i zaustavile promjene Zakona u smjeru liberalizacije radnog zakonodavstva.

Kao što je već spomenuto, neki se članci odnose na prikaz svih reformi koje su planirane, a koje se pretežito kreću u okvirima opće politike štednje, odnosno austeriteta, a kojih je fleksibilizacija tržišta rada sastavni dio. Također su prisutni novinski tekstovi koji se prvenstveno bave osvrtima na prijedloge reformi radnog zakonodavstva, odnosno općenite i pojedine izmjene Zakona o radu na koje također daju komentare predstavnici političke opozicije, pojedini novinari i društveni komentatori kao i znanstvenici i stručnjaci.

Radi pojednostavljivanja analize i lakšeg praćenja slijeda događanja u odnosu na proces fleksibilizacije tržišta rada liberalizacijom Zakona o radu, korpus članaka podijeljen je na dva dijela prema kronološkom redoslijedu prateći slijed tema i argumentacija koje najavljuju i prate spomenuti proces deregulacije; i to od 1. siječnja 2013. godine do 15. srpnja 2014. godine. S obzirom na to da je deregulacija tržišta rada na inicijativu Vlade Republike Hrvatske bila podijeljena na dva dijela, odnosno na izmjene postojećeg Zakona o radu koje su donesene 15. lipnja 2013. godine te na najavljivano donošenje potpuno novog i pojednostavljenog Zakona o radu do kraja 2013. godine, čije se donošenje zbog produljenja pregovora sa sindikata, ali i zbog nezadovoljstva poslodavaca protegnulo sve do 15. srpnja 2014. godine, korpus je pri analizi tema podijeljena na dva razdoblja.

TABLICA 7.1 Članci uključeni u uzorak podijeljeni u dva razdoblja

\begin{tabular}{|c|r|r|r|}
\hline Razdoblje & $1.1 .2013-15.6 .2013$ & $16.6 .2013 .-15.7 .2014$ & \\
\hline Broj članaka & 27 & 94 & 121 \\
\hline Ukupno & & & 94 \\
\hline
\end{tabular}

Broj članaka koji se odnosi na prvo, upola kraće razdoblje, više je nego trostruko manji od broja tekstova koji se odnose na reformu radnog zakonodavstva perioda koji je uslijedio, što je razumljivo s obzirom na to da su promjene koje su ugrađene, ili su trebale biti ugrađene $u$ novi Zakon o radu bile predmetom prijepora, kao i s obzirom na to da je prvo razdoblje izmjena 
Zakona bilo namijenjeno nužnim, ali u smislu fleksibilizacije u javnosti percipirano blažim izmjenama $\mathrm{i}$ to $\mathrm{u}$ sklopu usklađivanja hrvatskog zakonodavstva $\mathrm{s}$ europskom pravnom stečevinom prije pristupanja Hrvatske Europskoj Uniji. Unatoč takozvanim „blažim“ izmjenama u prvom razdoblju, nalazimo članke koji su pisani kao anticipacija značajne fleksibilizacije tržišta rada, pa je tako, kao što je već navedeno, prisutno propitivanje ograničenja prekovremenih radnih sati, kao i nemogućnost rada za više poslodavaca, ili pak uvođenje $\mathrm{u}$ diskurs usporedbi anglosaksonskih sustava radnih odnosa $\mathrm{s}$ kontinentalnim sustavom koji ipak naklonjeniji radnicima kada se radi o zaštiti prava radnika i samoj razvijenosti politika socijalne države.

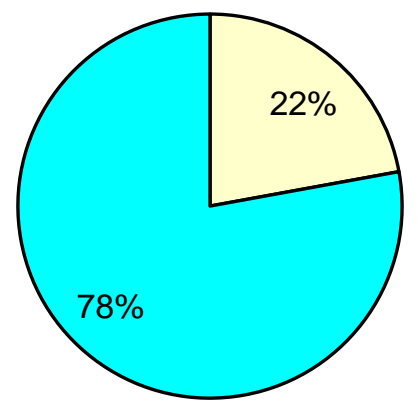

ㅁ1.1.2013 - 15.6.2013

ㅁ16.6.2013.-15.7.2014

\section{Grafički prikaz 7.1 Raspodjela analiziranih članaka prema razdobljima}

Za prvo je razdoblje karakteristično umjerenije pristupanje industrijskih aktera predloženim reformama, ali, zanimljivo, i veći udio članaka koji kritički sagledavaju predlagane reforme, a da se pritom pozivaju na pretpostavke koje podupiru i promiču diskurs socijalne države. Prve su izmjene zapravo bile usklađivanje Zakona s direktivama Europske unije prije pridruživanja Hrvatske Europskoj uniji 1. srpnja 2013. godine. Prijepora oko prvih izmjena nije bilo između ostalog i zbog društvenog konsenzusa oko pristupanja Europskoj uniji, ali i zbog izmjena Zakona o radu koje su, osim u dijelu izmjena koji se odnosio na ugovor na određeno vrijeme ne bi li se on doveo u okvire onog što je pristupanje zahtijevalo od usklađivanja hrvatskog zakonodavstva s onim europskim. A čak su se i izmjene koje su se ticale ugovora na određeno vrijeme prikazivale kao pozitivne za radnike. Također, zaštita radnika u okvirima Europske 
unije može se okarakterizirati zadovoljavajućom s obzirom na to da veći prijepori oko predloženih izmjena Zakona nisu bili predviđeni, dok su u drugom razdoblju reforme tržišta rada bile prisutne promjene za koje se unaprijed očekivalo da će uzrokovati značajne otpore na strani radnika, odnosno sindikata. 


\subsection{Glavne teme i akteri}

\subsubsection{Teme novinskih članaka iz razdoblja usklađivanja Zakona o radu $s$ direktivama Europske Unije (1. 1. 2013. - 15. 6. 2013.)}

Početkom 2013. godine, među izdvojenim člancima iz dnevnih listova koji se odnose na temu fleksibilizacije tržišta rada, nailazimo na udio članaka koji su orijentirani na održanje i obnovu politika koje povezujemo sa socijalnom državom, a koji je veći u odnosu na drugo analizirano razdoblje kada se uzme u obzir broj kritičkih tekstova u odnosu na ukupan broj članaka u tom razdoblju. U prvom se razdoblju pojavljuju članci koji kritički pristupaju neoliberalnim ekonomskim politikama i njihovom utjecaju na nastanak gospodarske krize te se također kritički odnose prema nastojanjima političkih elita, kako europskih, tako i domaćih, da boljke ekonomskog sustava koje su došle do izražaja tijekom posljednje gospodarske krize liječe dodatnom neoliberalizacijom politika, a osobito neoliberalnim politikama na tržištima rada kojima je cilj prebacivanje i odgovornosti za krizu i troškova krize na radnike. U okviru kritički orijentiranih članaka nailazimo na aktere kao što je čelnik Matice sindikata Vilim Ribić, intelektualac Antun Vujić, jedan polemički članak koji zapravo u dijalogičnom tonu odmjerava politike socijalne države i neoliberalne politike s uključivanjem nekoliko aktera, predstavnika političkih stranaka, sindikata, i ekonomskih stručnjaka, kao i izvješće UNCTAD-a koje ukazuje na pogubnost politike štednje i politika fleksibilizacije tržišta rada kojima je cilj ispravljanje boljki gospodarskih sustava $\mathrm{s}$ izraženim neoliberalnim nagnućima dodatnom neoliberalizacijom i smanjivanjem radničkih prava.

Druga tematska cjelina novinskih članaka iz navedenog razdoblja odnosi se na tekstove koji javnosti otkrivaju prijedloge Vlade o potrebnim izmjenama u radnom zakonodavstvu i manifestaciju dijaloga između industrijskih aktera i njihovih odluka u javnom diskursu. Akteri navedenih članaka jesu predstavnici Vlade Branko Grčić i Mirando Mrsić i komentari samih novinskih reportera, kolumnista te kritike koje dolaze od predstavnika sindikata i poslodavaca. U drugim su člancima predstavljene navedene prve izmjene Zakona o radu koja se dogodila 15. lipnja 2013. godine u kojima je glavni akter ministar rada i mirovinskog sustava Mirando Mrsić te nagovještaji mogućih promjena koje će biti ugrađene u potpuno novi Zakon o radu čime zapravo započinje javna rasprava o valu fleksibilizacije tržišta rada u Hrvatskoj koji će uslijediti. Kod usklađivanja Zakona o radu s direktivama Europske unije, dakle u prvoj fazi do 15. lipnja 2013. godine, kao najznačajniju izmjenu Vlada navodi ograničenje broja ugovora o radu na određeno koji mogu biti sklopljeni između pojedinog poslodavca i radnika, ali se ne 
spominje pitanje u kojim okolnostima je moguće sklapati ugovore na određeno ili mogućnosti sprječavanja prakse poslodavaca da zloupotrebljavaju institut ugovora na određeno.

Treća tematska cjelina članaka odnosi se na buduće reforme koje Vlada planira poduzeti kako bi se ostvario oporavak hrvatskog gospodarstva. Tema promjene Zakona o radu u odabranom se razdoblju analize uvodi u javni diskurs preko teme promjene sustava otpremnina, za koje se zbog njihovih visokih troškova navodi da onemogućavaju restrukturiranje tvrtki i sustava javnog sektora, odnosno da otežavaju lakše otpuštanje radnika. U javnom su diskursu kontinuirano prisutne teme različitih reformi koje predlažu poslodavci, a zapravo podrazumijevaju mjere politike štednje kao što su smanjenje državne potrošnje, smanjenje broja zaposlenih u javnom sektoru, smanjenje poreza i troškova rada, što onda podrazumijeva da je jedna od najvažnijih tema i njihovo viđenje fleksibilnog tržišta rada koje treba reformirati kako bi se zaštita radnika otklonila kao brana provođenju spomenutih politika štednje. Pozivi na reforme koji dolaze od poslodavaca zapravo su priprema za značajniju fleksibilizaciju tržišta rada koja je bila planirana u potpuno novom Zakonu o radu. U prvom razdoblju su u okviru tematske cjeline članaka o općim reformama u kontekstu krize i politike štednje, već prisutna reagiranja poslodavaca i njihovo zalaganje za što je moguće liberalniji novi Zakon o radu te negativne reakcije na ono što prema njihovim procjenama nije dovoljna liberalizacija radnog zakonodavstva. Renomirani predstavnici poslodavaca, na primjer, tadašnji predsjednik Hrvatske udruge poslodavaca Ivica Mudrinić izražava kritiku prema najavljivanim reformama Vlade, kao i ponudu pomoći poslodavaca za izlazak iz ekonomske krize predlaganjem niza reformi među kojima je i fleksibilizacija Zakona o radu. Tijekom mjeseci neposredno prije ljeta karakteristična ja tema izražavanja nezadovoljstva poslodavaca u turizmu nefleksibilnošću radnog zakonodavstva u Hrvatskoj koje im onemogućuje zakonito produljenje radnog dana, odnosno smanjenje pauze između dva radna dana, kao i nezadovoljstvo ograničenjem prekovremenih sati. Nadovezujući se na temu ograničenja radnih sati, pojavljuje se i tema maksimalnih radnih sati u mjesecu, pri čemu se dovodi u pitanje ograničavanje radnih sati, odnosno nemogućnost dodatne zarade radom kod više poslodavaca uvodeći u diskurs o tržištu rada mogućnost potpune liberalizacije broja radnih sati na tjednoj i mjesečnoj osnovi. Večernji list je također u diskurs nakratko pokušao uvesti temu mogućnosti ukidanja plaćanja godišnjeg odmora, prenijevši tekst nepoznatog američkog bloga u kojem se dovodi u pitanje europska praksa obaveznog godišnjeg odmora, odnosno instituta plaćenog godišnjeg odmora. Tijekom spomenutog razdoblja javne rasprave na taj su način analizirani dnevni listovi otvarali teme različitih, pa često i ekstremnih mogućnosti liberalizacije radnih odnosa. Među reakcijama na izmjene Zakona ističu se i pravni stručnjaci, kao što su Viktor Gotovac i Željko Potočnjak od 
kojih prvi iskazuje stručno nezadovoljstvo time što se reforma Zakona o radu podijelila na dva dijela, kao i svoje viđenje o tome što fleksibilizacija znači i kako bi se hrvatski radnik budućnosti trebao snalaziti na fleksibilnom tržištu rada. Valja napomenuti da bi konflacija procesa deregulacije tržišta rada u jednu izmjenu o kojoj ovisi mogućnosti ulaska Hrvatske u Europsku uniju dovela sindikate, a onda potencijalno i Vladu u jedan vrlo nepovoljan položaj. Pravnik Željko Potočnjak piše u sklopu rubrike Večernjeg lista „HUP-ov komentar“ gdje opisuje mogućnost uređenja tržišta rada u skladu s propozicijama fleksigurnosti kao nešto blaže varijante fleksibilizacije, a koja je prisutna u zapadnoeuropskim zemljama poput Danske.

Kao što je već navedeno, periodički se u čitavom korpusu pojavljuju izvještaji Državnog zavoda za statistiku i Eurostata o nezaposlenosti i stanju na hrvatskom tržištu rada kao alarmantnih i koji se u javnom diskursu instrumentaliziraju za zagovaranje fleksibilizacije tržišta rada, koja u navedenim člancima najčešće nije obrazložena, niti je opisano na koji bi se način ona odvijala, već se jednostavno predstavlja kao nešto što se naprosto mora provesti.

\subsubsection{Teme iz razdoblja javne rasprave, pregovora i donošenja novog Zakona o radu (16. 6. 2013. - 15. 7. 2014.)}

U drugom se razdoblju ako je suditi prema samoj brojnosti tekstova, značajnije u javnom diskursu pojavljuju članci povezani s fleksibilizacijom tržišta rada. Analizirani tekstovi su dio javnoga diskursa o prijedlogu novog Zakona, kao i predstavljanju pojedinih izmjena te pregovorima između industrijskih aktera i posljedicama prekida spomenutih pregovora. Najvažniji momenti u procesu donošenja Zakona o radu, a koji su utjecali na oblikovanje javnog diskursa jesu izlazak sindikata iz Gospodarsko-socijalnog vijeća krajem studenog 2013. godine, zatim priprema sindikata za referendum o općem štrajku, njegova organizacija, provođenje i objava rezultata. Paralelno s aktivnostima sindikata nastavlja se diskretno lobiranje poslodavaca za što liberalniji Zakon o radu u diskursu dnevnih listova kroz prijedloge za izlazak iz krize promoviranjem reformi čija je izmjena Zakona sastavni dio, kao i preporuke za privlačenje ulaganja, odnosno za poboljšanje pozicije Hrvatske na ljestvici konkurentnosti za što se također izmjena Zakona o radu u smjeru liberalizacije navodi kao jedan od važnih čimbenika. Vlada nakon prekida pregovora sa sindikatima nastavlja u javnom diskursu prezentirati pojedine prijedloge i mogućnosti reformiranja hrvatskog tržišta rada, koji prate proces donošenja Zakona, odnosno njegovo prihvaćanje u Vladi 23. siječnja 2014. godine te upućivanje Zakona u saborsku proceduru, izglasavanje Zakona o radu u prvom čitanju u Saboru 28. veljače 2014. 
godine, nakon čega je uslijedilo razdoblje obnove pregovora između industrijskih aktera, dogovor oko izmjena te samo donošenje Zakona o radu.

Nakon prve izmjene Zakona, već krajem kolovoza 2013. godine počinju se u analiziranim člancima pojavljivati glasovi kritike na prijedlog novog Zakona o radu. U proučenim je člancima raspravu o prijedlogu Zakona otvorio dopisnik Jutarnjeg lista Inoslav Bešker, izražavajući nezadovoljstvo sadržajem predloženih reformi i načinom na koji je država, koju on jedini uvodi kao aktera u reformama, zamislila fleksibilizaciju. Nakon njega pojavljuju se i glasovi opozicijskih stranaka, prvenstveno predstavnika stranke Laburista koji oglašavaju svoje nezadovoljstvo prijedlogom Zakona i čije se izjave prenose u vrlo kratkim člancima. Poslodavci također nude vlastite analize prijedloga Zakona o radu, kao i prijedloge reformi za koje smatraju da bi trebale biti ugrađene u novi Zakon. Vrlo je rijedak primjer da bilo koji predstavnik poslodavaca ulazi u otvoreni sukob s Vladom, odnosno njezinim predstavnicima, već poslodavci izražavaju kritike koje su najčešće ublažene tonom nastojanja pružanja pomoći političkoj eliti, pri čemu se implicitno sugerira da ona ne razumije ekonomske procese ili potrebu za reformama, niti zna koje reforme valja provoditi.

Kroz javni diskurs o izmjenama Zakona o radu, kao sredstvo pritiska poslodavaca korišteni su podaci nekoliko svjetskih organizacija, osobito Svjetske banke, o položaju Hrvatske na ljestvicama konkurentnosti te usporedbe Hrvatske s drugim zemljama kada je riječ o povoljnim uvjetima za privlačenje stranih ulaganja, kao jednog od čimbenika mogućnosti zemlje da prevlada gospodarsku krizu. Države s kojima je Hrvatska uspoređivana bile su na primjer, Makedonija, Gruzija, Srbija te zapadne, razvijenije ekonomije poput Velike Britanije i Portugala. Tema promicanja reformi, a s njima povezana i tema privlačenja stranih ulaganja, za koje se kao uvjet postavlja provođenje reformi (pa između ostalog i tržišta rada), osnovna je tema velikog dijela novinskih članaka koji se pojavljuju tijekom čitavog perioda iz kojega su preuzeti članci korpusa. Broj novinskih članaka koji se odnose na reforme i strana ulaganja kao glavnu temu udjelom je najveći u čitavom korpusu ako obuhvatimo oba razdoblja i čini oko 31 posto (Tablica 7.2). Te su dvije teme povezane i moguće ih je podvesti pod jedinstvenu skupinu članaka utoliko što svi članci o stranim ulaganjima sadrže u sebi kao podtemu potrebu provođenja reformi ne bi li stranim ulagačima bilo isplativije ulagati u hrvatsko gospodarstvo. Za razliku od teme stranih ulaganja, članci kojima je glavna tema reforme hrvatskog gospodarstva gotovo se uvijek zapravo odnose na provođenje politike štednje i rezanja potrošnje države. Dakle, u člancima o stranim ulaganjima traže se reforme koje će smanjiti cijenu rada i smanjiti poreze, a samim time predstavljaju učvršćivanje diskursa štednje odnosno, austeriteta, kao dijela neoliberalnog diskursa koji traži imploziju državnog, odnosno javnog 
sektora. Vrste reformi koje se zahtijevaju jesu smanjenje administrativnih barijera, državnog aparata, odnosno birokracije, fleksibilizacija tržišta rada, odnosno smanjenje troškova rada, kao i smanjenje poreza i drugih naknada državi, kao i stabilnost pravnog okvira. Akteri koji se redovito pojavljuju u spomenutim temama jesu najvećim dijelom poslodavci, ili njihovi predstavnici često predstavljeni kao ekonomski ili pravni stručnjaci, kao i redovni kolumnisti i novinari koji se bave određenim područjima, poput rada ili ekonomije. Kao i sami predstavnici Vlade, odnosno premijer, zatim ministri gospodarstva, rada, uprave, ali u mnogo manjem dijelu. Dok tema ulaganja, s posebnim naglaskom na stranim ulaganjima, gotovo isključivo proizlazi iz iskaza samih poduzetnika, bili oni predstavnici HUP-a, ili predstavnici Udruženja stranih ulagača. U tom smislu se u člancima o reformama, a osobito o ulaganjima, pojavljuje vrlo malo drugih aktera, što je inače slučaj sa svim novinskim člancima u kojima postoji glas poslodavaca. Kod članaka o reformama također postoji jedna skupina tekstova u kojima se tematizira sam način provođenja reformi, kao i procjena sposobnosti tadašnje Vlade da provede određene reforme. Navedena tema je svrstana u cjelinu „Reforme i strana ulaganja“ jer su te dvije teme, iako u načelu razlučive, međusobno vrlo tijesno povezane pa je izrazito teško u potpunosti ih razdvojiti u dvije zasebne kategorije.

S druge strane, cjelina članaka pod nazivom „Osvrti na Zakon o radu i odnose među industrijskim akterima“ također je teško razlučiva kategorija koja manifestno ne pripada niti kategoriji „Tripartitnog dijaloga“, niti kategoriji „Reforme i strana ulaganja“ jer se sastoji od kritika upućenih načinu na koji industrijski akteri pristupaju fleksibilizaciji rada, kritici Vlade i sindikata kada se radi o dijalogu o izmjenama Zakona i slično. Međutim, u pozadini te kritike često nailazimo na latentne preporuke o reformama ili pak politički motiviranu kritiku donošenja Zakona o radu bez konkretnih argumenata ili prijedloga koji bi se odnosila na procese deregulacije Zakona, odnosno na fleksibilizaciju tržišta rada. U ovu su kategoriju svrstani članci u kojima prevladavaju kolumne i komentari novinara i stručnjaka na političke konstelacije te društvene i gospodarske prilike, zatim intervjui sa stručnjacima, i kritike opozicijskih stranaka, prvenstveno stranke Hrvatskih laburista i HDZ-a.

Tijekom drugog razdoblja u tematsku kategoriju članaka pod nazivom „Tripartitni dijalog“ svrstavamo i članke kojima je tema Vladino predstavljanje konkretnih prijedloga reformi tržišta rada koji se pojavljuju u javnom diskursu tijekom pregovora industrijskih aktera, odnosno pregovora Vlade s poslodavcima i predstavnicima sindikata. U korpusu se u razdoblju koje traje godinu dana, a osobito nakon Vladina prihvaćanja Zakona, pojavljuju i tekstovi koji pojašnjavaju prihvaćene promjene te obavještavaju o rezultatima naknadnih pregovora između industrijskih aktera. Usuglašene promjene se periodički pojavljuju u novinskim tekstovima 
zajedno s komentarima predstavnika svih triju strana u pregovorima. U ovoj su kategoriji također članci u kojima poslodavci iznose svoje zahtjeve u javni diskurs kao i primjedbe na predložene izmjene koje je iznijela Vlada.

Nakon izlaska sindikata iz Gospodarsko-socijalnog vijeća zbog sukoba $\mathrm{s}$ predstavnicima Vlade pojavljuje se tematska kategorija članaka koju možemo označiti nazivom „Prekid pregovora i akcije sindikata“. To su članci u kojima su sindikati najistureniji akteri jer je tema tih tekstova sukob između sindikata i Vlade, a u određenoj mjeri i sindikata $i$ predstavnika poslodavaca. Sindikati nakon napuštanja pregovora s drugim partnerima nastoje ojačati pregovarački položaj organiziranjem sindikalnog referenduma među članstvom o generalnom štrajku o čijem tijeku je u člancima obavještavana javnost. U sklopu te teme pojavljuju se i kritike postupaka sindikata koje dolaze od predstavnika poslodavaca i osporavanje regularnosti generalnog štrajka od Vlade. Veliki dio članaka u ovoj kategoriji predstavlja prenošenje izjava čelnika sindikata koji uvjetuju smirivanje sindikalnih prosvjednih aktivnosti povlačenjem prijedloga Zakona o radu uz pozive ministra rada na nastavak pregovora. Nakon što je ustanovljeno da generalni štrajk nije regularan jer ga je po tada važećem Zakonu bilo moguće organizirati samo u slučaju kršenja materijalnih prava radnika, umjesto općeg štrajka organiziran je štrajk solidarnosti s radnicima dvije hrvatske tvornice u kojima oni nisu primali plaće, u jednom slučaju dvije godine, a u drugom osam mjeseci.

U drugom dijelu nešto više članaka tematizira nezaposlenost i na tragu toga zaziva promjene na tržištu rada, najčešće u smjeru njegova osuvremenjivanja i praćenja trendova fleksibilnosti u svijetu. Za članke kojima je tema nezaposlenost u Hrvatskoj najčešće se od svih članaka pozivaju na konkretne statističke pokazatelje i utemeljeni su na službenim podacima o stanju na tržištu rada, pa su samim time manje jednostranog nagnuća kada se radi o preporukama za izlazak iz krize tržišta rada na kojima vlada vrlo niska zaposlenost i visoka nezaposlenost. Također, članci o nezaposlenosti, iako ih ima svega nekoliko, imaju viši stupanj dijalogičnosti, odnosno problem stanja tržišta rada sagledavan je iz više perspektiva. U člancima u kojima je nezaposlenost glavna tema prevladavaju glasovi znanstvenika, sveučilišnih profesora, a često i odabranih običnih ljudi kao predstavnika glasa nezaposlenih, ali, kao što je ranije navedeno, ti slučajevi u korpusu nisu česti. 
TABLICA 7.2 Podjela članaka po temama

\begin{tabular}{|c|c|c|c|}
\hline Tema & I. Razdoblje & II. Razdoblje & 5 \\
\hline Kritički osvrti na politiku štednje & 4 & 1 & 26 \\
\hline Tripartitni dijalog & 7 & 30 & 38 \\
\hline Reforme i ulaganja & 8 & 17 & 24 \\
\hline $\begin{array}{c}\text { Osvrti na Zakon o radu i } \\
\text { odnose između industrijskih } \\
\text { aktera }\end{array}$ & 7 & 22 & 22 \\
\hline $\begin{array}{c}\text { Prekid socijalnog dijaloga i } \\
\text { akcije sindikata }\end{array}$ & 0 & 5 & 6 \\
\hline $\begin{array}{c}\text { Nezaposlenost } \\
\text { Ukupno }\end{array}$ & 1 & 94 & 121 \\
\hline
\end{tabular}

\section{Podjela članaka po temama}

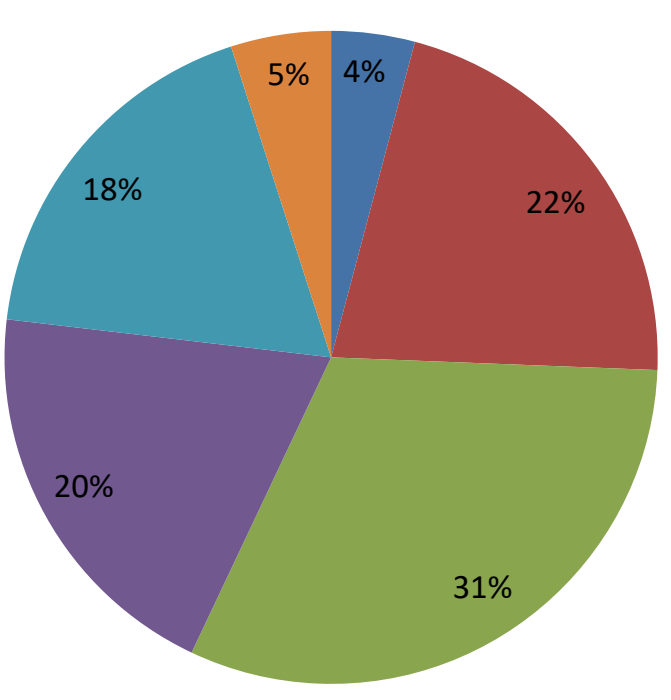

- Kritički osvrti na politiku štednje

- Tripartitni dijalog

Reforme i ulaganja

Osvrti na Zakon o radu i odnose između industrijskih aktera

Prekid socijalnog dijaloga i akcije sindikata

Nezaposlenost

Grafički prikaz 7.2 Udjeli članaka u uzorku po temama 


\subsection{Analiza novinskih tekstova odabranih u uzorak}

Nakon podjele rasporeda uzorka, pristupilo se kodiranju članaka što je proizvelo složenu hijerarhijsku strukturu kodova koji ukazuju na prevladavajuće teme u diskursu o fleksibilizaciji tržišta rada (Dodatak 1). U skladu sa samim karakteristikama materijala za analizu koji se sastoji od tekstova žanra novinskog članka koji podrazumijeva ranije navedenu semantičku makrostrukturu čije je težište automatizirano i rutinizirano eksplicitno isticanje glavne teme, kodiranje manjih značenjskih jedinica teksta, bile one odlomci, rečenice ili fraze, unekoliko se uklapalo u ustanovljene semantičke makrostrukture (van Dijk, 1988). Uzorak je prema tome već mapiran prema temama članaka o čemu je bilo riječi u poglavlju o odabiru članaka koji su uključeni u uzorak, kao i u prethodnom tekstu. Također, u istraživanju je kodiranje u određenoj mjeri korespondiralo raspodjelom tema prema temama samih članaka, ali je detaljno kodiranje pogonjeno teorijskim pretpostavkama, te dodatno usmjeravano postavljenim istraživačkim pitanjima, proizvelo specifičan obrazac pojavljivanja tema vezanih uz širi društveni kontekst fleksibilizacije tržišta rada.

Upoznavanje s materijalom za analizu započelo je u samoj pripremi materijala za analizu u programu MAXQDA, to jest u pretvaranju PDF datoteka u tekstualne. Braun i Clarke (2006) opisuju šest faza u procesu tematske analize, a to su: 1) upoznavanje s materijalom, 2) stvaranje inicijalnih kodova, 3) traženje tema, 4) revidiranje pronađenih tema, 5) imenovanje tema i 6) sastavljanje izvještaja. S obzirom na ranije opisana ishodišta ovog istraživanja (konstruiranje uzorka prema unaprijed određenom pojmu „fleksibilizacije tržišta rada“ $\mathrm{i}$ analiza žanra novinskih članaka koji imaju unaprijed postavljenu semantičku makrostrukturu), neke od navedenih faza su u procesu analize spojene, pa se kodiranje odvijalo u smislu produbljivanja već datih tema i pronalaženja dimenzija i nijansi javne artikulacije procesa fleksibilizacije tržišta rada koje razotkrivaju pozadinsko znanje i ideološke pretpostavke pojedinih izjava u javnome diskursu. Prva faza kodiranja odvijala se kroz iščitavanje tekstova prema kronološkom redoslijedu izlaženja članaka. Naime, podjela kodova prema temama članaka bila je podloga za daljnje detaljnije kodiranje tema u uzorku (Saldaña 2013). S obzirom na široki raspon tema članaka u analiziranom materijalu, nastala kodna shema bila je podosta „razmrvljena“ na različite teme, ali s velikim brojem ponavljanja specifičnih kodova u uzorku unutar uspostavljenih tematskih cjelina, što govori o retorički vrlo monotonom materijalu, odnosno ukazuje na materijal kojega odlikuje ponavljanje jednostavnih poruka, s relativno malo sadržaja. 
Druga faza kodiranja sastojala se od dodatnog automatiziranog kodiranju pomoću programa MAXQDA na temelju ključnih riječi ustanovljenih u prvoj fazi detaljnog kodiranja iz čega je proizašao dojam o čestosti pojavljivanja pojedinih riječi u tekstovima. S obzirom na to da samo pojavljivanje riječi nije upućivalo na kontekst u kojem se ona nalazi, kao korisna funkcija pokazala se operacija pronalaženja zajedničkog pojavljivanja više riječi unutar istog odlomka u članku, takozvani „,code relation“. Na taj je način bilo moguće uspostaviti odnose između riječi koje upućuju na određene teme dodavanjem „osi“ značenja ne bi li se otkrili obrasci u javnom diskursu o fleksibilizaciji tržišta rada.

Tematske cjeline koje su uže vezane uz liberalizaciju radnog zakonodavstva i pojavljuju se $u$ javnom diskursu mogu se između ostalog grupirati ili kategorizirati prema spomenutim vrstama fleksibilnosti od kojih je najistaknutija ona numerička.

\subsubsection{Prijedlozi promjena Zakona o radu u području numeričke fleksibilnosti}

U kontekstu numeričke fleksibilnosti koja u javnom diskursu ima prilično veliku težinu, promišljanje o olakšavanju otkaza jedna je od najvažnijih tema koje se pojavljuju u analiziranom korpusu. Olakšavanje otkaza i snižavanje troškova otpuštanja radnika prioritetno je područje liberalizacije tržišta rada za poslodavce, bez obzira na to radilo se o većim kompanijama, ili malim i srednjim poduzetnicima zbog kojih su predstavnici poslodavaca tražili da se u Zakon o radu ugradi odredba koja bi za male poslodavce omogućila potpunu liberalizacija otkaza, odnosno mogućnost davanja otkaza bez objašnjenja.

Prema svemu sudeći, Hrvatska udruga poslodavaca uspjela je u svojoj namjeri da se malim poslodavcima olakša pozicija u novom Zakonu o radu. Prijedlog koji je u dosadašnjim pregovorima Ministarstva rada, poslodavaca $i$ sindikata praktički usuglašen potvrdilo nam je više pregovarača, a to znači da bi mali poslodavci do pet zaposlenih ubuduće mogli otkazivati ugovore o radu bez ikakvog obrazloženja.

(Gordana Galović, Jutarnji list, 7. 4. 2014.)

Drugi prijedlog izmjene radnog zakonodavstva također se odnosio na smanjivanje troškova otkaza, a to je bio prijedlog izmjena sustava otpremnina. Prema prijedlogu Vlade 
trebalo je doći do smanjivanja visine otpremnina, a kao kompenzacija radnicima predloženo je povećanje naknade za nezaposlenost. Ministar rada i mirovinskog sustava također je predlagao osnivanje fonda za otpremnine po uzoru na austrijski model, u koji bi poslodavci za radnike mjesečno uplaćivali određeni iznos, koji bi se radniku isplaćivao u slučaju otkaza. Poslodavci su ovi promjenu vidjeli kao trošak i način da sama država sebi olakša i smanji troškove otpuštanja radnika u javnom sektoru pa nisu podržavali tu promjenu, od čega se na kraju i odustalo.

Još jedan aspekt fleksibilizacije tržišta rada koji možemo povezati s numeričkom fleksibilnošću tiče se ugovora na određeno, koji poslodavcu olakšava smanjivanje zaposlenika, odnosno facilitira fleksibilniju raspodjelu radne snage na kraći rok jer ga oslobađa dugoročnih financijskih obaveza prema radniku. Istekom roka specificiranog u ugovoru na određeno, poslodavac ima mogućnost smanjiti trenutnu radnu snagu bez ikakvih dodatnih troškova. Vlada je predlagala, zbog usklađivanja hrvatskog radnog zakonodavstva s onim Europske unije, ukidanje roka na koji zaposlenik može biti po prvi puta zaposlen na određeno. Dakle, prvi ugovor na određeno ne mora imati rok trajanja, već ovisi o potrebama posla zbog kojeg je netko zaposlen.

Kao način zaobilaženja financijskih i vremenskih resursa poslodavaca na otkaze radnicima, u javnom je diskursu snažno promicano zapošljavanje preko agencija za privremeno zapošljavanje, kao jednog od mogućih fleksibilnijih oblika zapošljavanja. U javnom su diskursu često agencije spominjane kao jedan od fleksibilnih oblika rada koji je na lošem glasu, ali koji svakako treba uzimati u obzir u kriznim vremenima, kada poslodavci zaziru od preuzimanja obaveze zapošljavanja novih radnika. U sklopu teme koja se odnosi na agencijski rad, sindikati su izražavali snažno protivljenje izmjenama koje su u povoljniji položaj postavljali agencije za privremeno zapošljavanje kritizirajući upitnu razinu prava koje takve agencije osiguravaju svojim zaposlenicima.

Prođe li taj prijedlog, umjesto godine dana, agencijski bi radnici na istim radnim mjestima mogli raditi do tri godine, a otvara se $i$ mogućnost da rade za nižu plaću - kaže Mladen Novosel iz SSSH. Sve je više primjera po tvrtkama da agencijski radnici rade za bitno manje plaće od radnika tvrtki koje ih angažiraju, a kad im istekne ugovor, ostaju bez primanja čak i ako imaju ugovor o stalnom radnom odnosu u agenciji.

(Mladen Novosel, prema: Lj. Gatarić Večernji list, 16.1.2014) 


\subsubsection{Prijedlozi promjena Zakona o radu u području fleksibilnosti plaća}

Najveći dio svih zahtjeva u uzorku javnog diskursa o fleksibilizaciji tržišta rada usmjeren je na mogućnosti korekcije plaća od poslodavaca kao odgovor na promjenjive gospodarske uvjete i gospodarsku krizu, čime se omogućava lakša prilagodba poslodavaca. Rasprave i zahtjevi usmjereni na korekciju plaća jedna su od najvažnijih i najistaknutijih tema, osobito vezana uz zahtjeve poslodavaca, ali i predmet spora za sindikate. Plaće su također važne i Vladi, odnosno državi koja u uvjetima gospodarske krize i smanjenja proračunskih prihoda nastoji smanjiti njihov obujam, u čemu je sprječavaju kolektivni ugovori.

Također pitanje plaća proteže se kao pitanje i u drugim oblicima fleksibilnosti, pa je i jedan od za sindikate spornih aspekata rada preko agencija za privremeno zapošljavanje pitanje jednakosti plaća ustupljenih radnika s plaćama zaposlenika same tvrtke u kojoj agencijski radnici privremeno rade.

Kada je riječ o temi smanjenja plaća tu pripadaju i prijedlozi Vlade koji idu u smjeru promjena koje bi omogućile smanjivanje plaća državnim službenicima koji umjesto ugovora o radu dobivaju rješenje. Spominju se i prijedlozi međunarodnih organizacija kao što je MMF koji predlaže neku vrstu smanjivanja plaća čiji je poslodavac država, kako bi se smanjili njezini rashodi. Pozivanje na smanjivanje plaća u državnom i javnom sektoru ističe se u nekoliko naslova koji na to pozivaju, kao na primjer: „Velika analiza: Hrvatska je u najtežoj krizi, a od svih je najmanje rezala plaće birokratima” i „Nećemo izaći iz krize ako Vlada ne smanji plaće službenicima i ne počne otpuštati“. Svjetska banka se u svojim preporukama za postizanje bolje konkurentnosti također osvrtala na „rigidnost plaća utvrđenih kolektivnim ugovorima“.

\subsubsection{Prijedlozi promjena Zakona o radu u području fleksibilnosti radnog vremena}

Najistaknutije pitanje kada je riječ o fleksibilnosti radnog vremena jesu zahtjevi poslodavaca, osobito poslodavaca koji se bave djelatnošću turizma, za mogućnostima produljenja maksimalnog prekovremenog rada čime se stvaraju određene uštede na području potencijalnog zapošljavanja. U tekstovima koji u uzorku kronološki dolaze na početku analize, fleksibilnost radnog vremena odnosi se na smanjivanje pauze između smjena za sezonski rad što se opravdava ograničenjima stvarnih okolnosti rada u turizmu. Nakon prvih izmjena Zakona o radu, zahtjevi povezani s fleksibilnošću radnog vremena odnose se na maksimalan iznos sati prekovremenog rada. Poslodavci se zalažu za veće mogućnosti korištenja prekovremenog rada zbog ušteda u zapošljavanju, dok se sindikati protive navedenoj mjeri koja, osim što predstavlja 
opterećenje za radnike koji rade prekovremene sate, smanjuje vjerojatnosti novog zapošljavanja radnika jer se prekovremenim radom može kompenzirati povećanje potrebe za novim radnicima.

\subsubsection{Gospodarska kriza i mjere štednje}

U javnom diskursu postoji nekoliko manjih tema ili podtema koje se mogu smjestiti u okvire jedne opće teme kao što je utjecaj gospodarske krize na tržište rada u smislu porasta nezaposlenosti te mjera koje valja poduzeti da bi se iz te krize izašlo, odnosno načinima za koje se vjeruje da bi trebali pokrenuti gospodarstvo. Kao odgovor na pitanje kako izaći iz gospodarske krize u javnom diskursu su predstavljeni prijedlozi kako ostvarivati uštede, a jedan od načina ostvarivanja ušteda jesu strukturne reforme, osobito u javnom sektoru. Valja istaknuti da se pod strukturnim reformama ili pod restrukturiranjem u većini slučajeva misli na uštede u javnom, odnosno državnom sektoru, i to u masi plaća, smanjenju broja zaposlenih, kao i omogućavanjem lakšeg otpuštanja. Kod tema o strukturnim reformama karakteristična je preskriptivna forma izražaja u javnom diskursu pri čemu se misli na didaktički karakter opisivanja mjera i reformi koje su potrebne za izlazak iz krize, a to su preporuke koje najčešce dolaze od poslodavaca, i ekonomskih i pravnih stručnjaka koji se zalažu za mjere i preporuke koje su već predložene od Međunarodnog monetarnog fonda ili Svjetske banke i to sve pod pretpostavkom da će ovakve promjene dovesti do pozitivnih pomaka u ublažavanju loših trendova na tržištu rada.

U javnom diskursu o fleksibilizaciji tržišta rada u najvećem su obujmu prisutne teme kao što je potreba za zapošljavanjem. U kontekstu novinskih tekstova, međutim, problematika zapošljavanja i potrebe za zapošljavanjem, odnosno načina na koji bi se trebalo postići zapošljavanje povezuje se s uvjetovanjem provedbe određenih aspekata fleksibilizacije tržišta rada. S obzirom na to da je jedna od istaknutijih tema u uzorku i tema gospodarske krize i načina na koji krizu treba prebroditi, onda se u tom kontekstu nameće i pojava problema povećanja nezaposlenosti i s njome povezanih nastojanja da se ostvari porast radnih mjesta i broj zapošljavanja. Osnovna premisa koja se uvijek iznova ponavlja u javnom diskursu o fleksibilizaciji jest ta da je sama funkcija najavljenih promjena na tržištu rada upravo omogućavanje zapošljavanja, pa su na taj način sve predložene promjene opravdavane ukazivanjem na to da je uvjet novog zapošljavanja provođenje predloženih promjena na tržištu rada u djelo. S obzirom na to da su poslodavci ti koji zapošljavaju, u javnom diskursu oni, i Vlada i njezini predstavnici, ističu koje promjene su potrebne da bi došlo do većeg 
zapošljavanja, a to su najčešće politike štednje. S druge strane, sindikati su akteri koji zagovaraju politiku potrošnje u javnom diskursu, mada takvih primjera nema mnogo, i njihovo sudjelovanje u javnom diskursu najčešće je svedeno na kritike predloženih promjena.

S obzirom na to da se diskurs socijalne države smatrao jednim od inicijalnih ishodišta za konstruiranje ovog rada kao antiteza neoliberalnim promišljanjima, u kontekstu krize u javnom diskursu o fleksibilizaciji tržišta rada vidimo da oponiranja diskursa povezanih sa socijalnom državom gotovo da i nema. O javnoj se potrošnji u okviru spomenutog diskursa govori izrazito malo, gotovo uopće ne u smislu mogućnosti oko koje bi se mogla izgrađivati gospodarska politika na tragu učvršćivanja socijalne sigurnosti, odnosno socijalne države. Naime, kao što je u neku ruku vidljivo iz Tablice 7.3 pojam potrošnje se supojavljuje u okviru istih odlomaka s pojmovima koji se odnose na politiku austeriteta. Naime, najveći razmjerni broj supojavljivanja pojmovi ,javni sektor“, „strukturne reforme“, „štednja“, i „potrošnja“ imaju s pojmom „plaća“, odnosno s temom smanjivanja plaća $i$ to u javnom sektoru. $U$ novinskim se člancima također kao uvjet privatnih ulaganja navodi provođenje politika štednje koja donosi rezove, strukturne reforme i upravo smanjenje potrošnje javnog sektora. Da su predlagane strukturne reforme izraz politike štednje, ukazuju i teme koje se pojavljuju zajedno s tim pojmom čiji sam naziv na prvi pogled ne evocira nužno pomisao na uštede i rezove. To su teme koje posredno predstavljaju zahtjeve kapitala, osobito inozemnog kapitala, koji svoj ulazak u hrvatsko gospodarstvo uvjetuje i provođenjem strukturnih reformi. Predstavnici stranih ulagača u Hrvatskoj često prizivaju strukturne reforme, ali i predstavnici hrvatskih poslodavaca ističući potrebu ostvarivanja ušteda u javnome sektoru.

Podaci iz Tablice 7.3 također upućuju na to da pojam restrukturiranja označava zapravo otpuštanje radnika, a liberalizacijom radnog zakonodavstva i proširivanjem mogućnosti davanja otkaza nastoji se potaknuti poslodavce da zapošljavaju jer mogu računati na to da će u budućnosti lakše otpuštati uz manje troškove. U ovakvoj se konstelaciji argumenata o odnosima fleksibilizacije, lakšeg otpuštanja, a posljedično i veće spremnosti na zapošljavanje jasno prepoznaje zanemarivanje potreba radnika, osim dobivanja bilo kakvog zaposlenja. Strukturne su reforme tako često spominjane i u kontekstu jačanja stupnja konkurentnosti Hrvatske, u okviru mjerenja ekonomske efikasnosti različitih država, pa time i uvjetovanja investicija koje traže povrat uloženog kapitala i profit. 
TABLICA 7.3 Supojavljivanje tema povezanih s politikom austeriteta

\begin{tabular}{|c|c|c|c|c|}
\hline & javni sektor & štednja & strukturne reforme & potrošnja \\
\hline javni sektor & 0 & 2 & 6 & 2 \\
\hline investicije & 5 & 9 & 13 & 8 \\
\hline korupcija & 0 & 1 & 1 & 0 \\
\hline štrajk & 3 & 1 & 0 & 0 \\
\hline socijalni dijalog & 1 & 3 & 1 & 0 \\
\hline socijalni partneri & 1 & 1 & 0 & 0 \\
\hline potreba za zapošljavanjem & 4 & 1 & 8 & 3 \\
\hline porezi & 4 & 4 & 6 & 6 \\
\hline štednja & 2 & 0 & 4 & 5 \\
\hline otpremnine & 3 & 0 & 4 & 0 \\
\hline otkaz & 8 & 4 & 12 & 3 \\
\hline rad na određeno & 3 & 1 & 9 & 3 \\
\hline nezaposlenost & 6 & 5 & 10 & 6 \\
\hline agencijski rad/privremeno zapošljavanje & 0 & 0 & 1 & 0 \\
\hline plaće & 15 & 10 & 10 & 11 \\
\hline radno vrijeme & 5 & 1 & 6 & 2 \\
\hline socijalna država & 0 & 0 & 1 & 1 \\
\hline konkurentnost & 4 & 3 & 13 & 5 \\
\hline kriza & 0 & 0 & 1 & 1 \\
\hline strukturne reforme & 6 & 4 & 0 & 2 \\
\hline potrošnja & 2 & 5 & 2 & 0 \\
\hline
\end{tabular}

\subsubsection{Gospodarska kriza i privlačenje stranih ulaganja}

Kao jedna od važnijih tema koje se povezuju s fleksibilizacijom tržišta rada jesu i uvjeti koje se postavljaju za privlačenje stranih ulaganja. Naime, politike tadašnje Vlade orijentirane su prema privlačenju stranog kapitala kao oblika potrošnje u vremenima krize. U javnom diskursu o fleksibilizaciji tržišta rada, liberalizacija radnog zakonodavstva navedena je kao jedan od čimbenika privlačenja stranih investitora koji u javnom diskursu ukazuju na promjene koje vladajući trebaju provesti da bi pokazali kako je Hrvatska zemlja u koju vrijedi ulagati, odnosno zemlja gdje se mogu ostvarivati odgovarajući profiti. Kao što je iz Tablice 7.4 vidljivo, najvažnija tema koja se pojavljuje u kontekstu teme o (stranim) investicijama je smanjivanje poreznog opterećenja, a time je povezan i status Hrvatske na ljestvicama konkurentnosti koji utječe na privlačnost kada su u pitanju ulaganja. Predstavnici stranih ulagača i domaćih poduzetnika u javnom diskursu kontinuirano upozoravaju na preveliko porezno opterećenje $u$ Hrvatskoj, a kao jedan od uzroka navode i ,rigidno“ tržište rada, odnosno ,zastario“ Zakon o radu koji onemogućuje smanjivanje broja zaposlenih u javnom sektoru i državnim službama, čijim bi se smanjivanjem otvorio prostor za snižavanje poreznog opterećenja. 
TABLICA 7.4 Supojavljivanje tema povezanih s temom ulaganja

\begin{tabular}{|l|r|}
\hline & ulaganja \\
\hline javni sektor & 5 \\
\hline ulaganja & 0 \\
\hline korupcija & 6 \\
\hline štrajk & 4 \\
\hline socijalni dijalog & 6 \\
\hline socijalni partneri & 3 \\
\hline poticanje zapošljavanja & 18 \\
\hline smanjivanje poreza & 34 \\
\hline smanjivanje rashoda - štednja & 9 \\
\hline promjene u otpremninama & 4 \\
\hline liberalizacija otkaza & 9 \\
\hline rad na određeno & 6 \\
\hline nezaposlenost & 16 \\
\hline agencijski rad/privremeno zapošljavanje & 2 \\
\hline fleksibilnost plaća/promjene u plaćama & 16 \\
\hline fleksibilnost radnog vremena & 6 \\
\hline socijalna država & 2 \\
\hline konkurentnost & 21 \\
\hline gospodarska kriza u hrvatskoj & 0 \\
\hline provođenje strukturnih reformi & 13 \\
\hline državna potrošnja & 8 \\
\hline
\end{tabular}

\subsubsection{Tripartitni dijalog i akcije sindikata}

Tema u kojoj najvažniju ulogu u javnom diskursu imaju sindikati je, očekivano, tema štrajka, ali i tema pregovora s drugim industrijskim akterima o predlaganim izmjenama Zakona o radu. Karakteristično je za javni diskurs o fleksibilizaciji tržišta rada da su sindikati zaista najznačajnije zastupljeni u tekstovima u kojima oni predstavljaju glavne aktere kao pokretači mogućeg štrajka. Sindikati, iako su bili u određenoj mjeri prisutni u tekstovima koji su objavljivani prije njihova izlaženja iz Gospodarsko-socijalnog vijeća, kada su oni najčešće komentirali različite ideje i prijedloge koji su se odnosili na liberalizaciju radnog zakonodavstva, njihovo značajnije prodiranje u javni diskurs dogodilo se tek najavom referenduma o općem štrajku, kao i samim pripremama za mogućnost štrajka, pa na koncu i održavanjem štrajka solidarnosti. 
TABLICA 7.5 Supojavljivanje tema povezanih s odnosima među industrijskim akterima

\begin{tabular}{|c|c|c|c|}
\hline & štrajk & socijalni dijalog & socijalni partneri \\
\hline Vlada & 15 & 23 & 11 \\
\hline poslodavci & 14 & 29 & 11 \\
\hline sindikati & 38 & 44 & 10 \\
\hline javni sektor & 3 & 1 & 1 \\
\hline investicije & 4 & 6 & 3 \\
\hline ulaganja & 0 & 2 & 2 \\
\hline korupcija & 0 & 1 & 0 \\
\hline štrajk & 0 & 10 & 2 \\
\hline poduzetnici & 4 & 2 & 2 \\
\hline socijalni dijalog & 10 & 0 & 13 \\
\hline socijalni partneri & 2 & 13 & 0 \\
\hline potreba za zapošljavanjem & 6 & 6 & 6 \\
\hline smanjivanje poreza & 2 & 3 & 2 \\
\hline smanjivanje rashoda/štednja & 1 & 3 & 1 \\
\hline promjene u otpremninama & 2 & 5 & 4 \\
\hline liberalizacija otkaza & 7 & 8 & 1 \\
\hline rad na određeno & 5 & 7 & 5 \\
\hline nezaposlenost & 4 & 8 & 3 \\
\hline agencijski rad/privremeno zapošljavanje & 6 & 3 & 1 \\
\hline fleksibilnost plaća/promjene u plaćama & 14 & 12 & 4 \\
\hline fleksibilnost radnog vremena & 7 & 5 & 7 \\
\hline socijalna država & 0 & 0 & 0 \\
\hline konkurentnost & 3 & 4 & 1 \\
\hline gospodarska kriza u hrvatskoj & 0 & 1 & 0 \\
\hline investitor & 1 & 3 & 2 \\
\hline provođenje strukturnih reformi & 0 & 1 & 0 \\
\hline državna potrošnja & 0 & 0 & 0 \\
\hline
\end{tabular}

U Tablici 7.5 prikazana su preklapanja tema s naglaskom na skupinu tema koja je najviše povezana sa samim sindikatima, a to su štrajk, socijalni dijalog i socijalni partneri. Za javni je diskurs karakteristično to što se u tekstovima koji se odnose na spomenute teme, spominje vrlo malo drugih tema ili argumentacija koje bi išle u smjeru obrazlaganja ili smislenog i argumentiranog oponiranja fleksibilizaciji tržišta rada i liberalizaciji radnog zakonodavstva na temelju zagovaranja principa socijalne države. Svi spomenuti novinski tekstovi prenose vijesti o kategoričnosti sindikalnog uvjetovanja suradnje, socijalnog dijaloga i ublažavanja kolektivnih akcija zaustavljanjem procedura donošenja Zakona o radu. U javnom diskursu postoji tendencija da se sindikati prikazuju kao akteri koji postavljaju ultimatume prijetnjama poduzimanja kolektivnih akcija, odnosno prosvjeda i štrajkova, kao što je na primjer istaknuto u naslovu nekih članka: „SINDIKATI: Bez štrajka barem pola godine ako se toliko odgodi ZOR“ (Večernji list, 11.2.2014.) ili „PONUDA SINDIKATA: Povucite ZOR pa mi nećemo u veliki štrajk“" (Jutarnji list, 11.2.2014.). 
U okviru ove tablice i plaće predstavljaju temu koja se često pojavljuje u kontekstu odabranih tema, međutim, to se pojavljivanje možda može pojasniti time da su plaće, odnosno zagovaranje smanjivanja plaća od poslodavaca i vlasti, kao i upozorenja sindikata na posljedice mjera koje će dovesti do manjih plaća, jedna od najspominjanijih tema u kontekstu promjena Zakona o radu i, očekivano, osnovno pitanje zaštite radničkih prava i zaštite interesa poslodavaca s druge strane.

\subsubsection{Interesi industrijskih aktera}

Prikazivanjem supojavljivanja industrijskih aktera pomoću funkcije programa MAXQDA pod nazivom „,code relation“ moguće je približno izvesti zaključke koje su teme značajnije za pojedine aktere od drugih, odnosno s kojim se kodiranjem ustanovljenim temama industrijski akteri najčešće povezuju. Kao što je u tablici prikazano teme u kojima se svo troje aktera pojavljuje u broju većem od 20 jesu socijalni dijalog i tema plaća. Dakle, u javnom su diskursu pregovori između industrijskih aktera u kontekstu diskursa o fleksibilizaciji tržišta rada u većoj mjeri povezani od drugih spomenutih tema, s time da pojedinačno najveću supojavnost ostvaruju sindikati kao akter, što upućuje na značajnije povezivanje tema sindikata i socijalnog dijaloga u javnom diskursu. Druga tema koja je u javnom diskursu u velikoj mjeri povezana $\mathrm{s}$ industrijskim akterima jest pitanje plaća. Također je moguće intrepretirati supojavnost kodiranih tema sa svakim akterom pojedinačno i vidjeti koje se teme u diskursu najviše povezuju s pojedinom stranom u socijalnom dijalogu. Vlada, i predstavnici Vlade, najviše se u diskursu dovode u vezu s problemom ili pitanjem plaća, nakon toga problemom nezaposlenosti, a nakon toga s ulaganjima, odnosno investicijama. Ovakva se konstelacija odnosa tema, odnosno kodova može rastumačiti kao usredotočenost vlasti na tri ključna područja koja bi trebala omogućiti olakšavanje gospodarskog oporavka Hrvatske, a to su ulaganja privatnog sektora (osobito strana ulaganja) kao izvor potrošnje u gospodarstvu, problem nezaposlenosti kao gorući problem koji se u tadašnjem razdoblju vezuje uz tada aktualno stanje na tržištu rada koje jest jedno važno političko pitanje s kojim se suočavaju sve vlade i države, kao i na koncu pitanje plaća koje je, kao što je već u Tablici 7.3 opisano, povezano sa smanjivanjem državne potrošnje i plaća u javnom sektoru. Država, odnosno tada aktualna vlast nastoji se boriti protiv postojeće krize privlačenjem (stranih) ulaganja, odnosno dotokom kapitala u hrvatsku ekonomiju, smanjivanjem plaća u javnom sektoru čime bi se smanjili i državni rashodi, kao i postizanjem cilja fleksibilizacije koja s jedne strane može znači olakšanje smanjivanja plaća, ali i privlačenje stranih ulagača smanjivanjem cijene rada i sve to 
kroz pregovore, odnosno socijalni dijalog sa sindikatima i poslodavcima. Sindikati, kao što je prije navedeno najčešće su spomenuti u okviru teme socijalnog dijaloga. Nezadovoljni socijalnim dijalogom, odnosno pregovorima s drugim stranama, a zatim, što je i očekivano, zbog samog nezadovoljstva postojećim socijalnim dijalogom organiziranja štrajka, koji onda čini drugu temu po važnosti, ukoliko kao relevantan uzmemo kriterij supojavljivanja pojmova koji ukazuju na opisane teme prisutne u javnom diskursu. Još jedna tema koja se, uz već spomenute plaće nadaje kao važna jest radno vrijeme, kao komponenta fleksibilnosti kojoj se sindikati protive, kao i naglašavanje potrebe zapošljavanja, odnosno u slučaju sindikata to je najčešće isticanje kako predložene izmjene Zakona o radu neće proizvesti željeno i obećano zapošljavanje.

Poslodavcima je podjednako važan velik broj tema koje se odnose na konkretne mjere fleksibilizacije. Očekivano, poslodavcima je najvažnija mjera koja se odnosi na smanjenje troškova usmjeravanjem reformi na jaku numeričku fleksibilnost, pa je tako u okviru svih tema poslodavcima najvažnije pitanje otkaza, međutim valja napomenuta da u okviru teme otkaza poslodavci u velikom broju slučajeva pozivaju na otkaze u javnom sektoru. Druge teme koje se $\mathrm{u}$ javnom diskursu nameću kao povezane $\mathrm{s}$ interesima poslodavaca u javnom diskursu jesu zapošljavanje, plaće, radno vrijeme, rad na određeno, a tek nakon ovih tema po važnosti dolazi i tema socijalnog dijaloga. U okviru teme zapošljavanja, većinu svojih zahtjeva poslodavci poprate s obećanjem značajnijeg zapošljavanja radnika. Dakle, oni u svojim zahtjevima kao argument rabe potrebu liberalizacije radnog zakonodavstva ne bi li se ostvarila značajnija zapošljavanja s njihove strane. Mada je zapravo točnije ustvrditi da zapošljavanje nije izravno, a pogotovo ne kauzalno povezano sa stupnjem fleksibilizacije tržišta rada, iako povremeno i sami poslodavci ukazuju na činjenicu da je potreban drugačiji pristup reformama ukoliko se želi potaknuti zapošljavanje, čiji je Zakon o radu manje bitan čimbenik, ali čimbenik koji je svejedno predmet interesa utoliko što im omogućuje sniženje cijene rada. 
TABLICA 7.6 Teme u javnom diskursu o fleksibilizaciji i industrijski akteri

\begin{tabular}{|c|c|c|c|}
\hline & Vlada & sindikati & poslodavci \\
\hline javni sektor & 12 & 9 & 6 \\
\hline investicije & 24 & 11 & 11 \\
\hline korupcija & 2 & 1 & 0 \\
\hline štrajk & 15 & 38 & 14 \\
\hline socijalni dijalog & 23 & 44 & 29 \\
\hline socijalni partneri & 11 & 10 & 11 \\
\hline potreba za zapošljavanjem & 14 & 24 & 43 \\
\hline porezi & 16 & 8 & 10 \\
\hline štednja & 9 & 3 & 6 \\
\hline otpremnine & 15 & 10 & 26 \\
\hline otkaz & 14 & 21 & 47 \\
\hline rad na određeno & 15 & 13 & 33 \\
\hline nezaposlenost & 24 & 19 & 23 \\
\hline agencijski rad/privremeno zapošljavanje & 5 & 14 & 16 \\
\hline plaće & 35 & 25 & 44 \\
\hline radno vrijeme & 13 & 26 & 37 \\
\hline socijalna država & 1 & 1 & 1 \\
\hline konkurentnost & 9 & 15 & 15 \\
\hline kriza & 0 & 1 & 0 \\
\hline investitor & 8 & 7 & 4 \\
\hline strukturne reforme & 13 & 5 & 10 \\
\hline potrošnja & 4 & 3 & 1 \\
\hline
\end{tabular}

\subsection{Interdiskurzivna analiza}

Kroz analizu tekstova koji predstavljaju dio javnog diskursa o fleksibilizaciji tržišta rada ustanovljeni su oblici argumentiranja koji se odnose na promicanje određene vrste fleksibilizacije tržišta rada, a u manjoj mjeri i na osporavanje njezina uvođenja, i moguće ih je razvrstati prema stupnju ideološke bliskosti s neoliberalnim diskursom, odnosno bliskosti s oponirajućim diskursom socijalne države. Iako se pitanje fleksibilizacije tržišta rada u javnom diskursu može svesti na zagovornike i protivnike specifičnih aspekata fleksibilizacije, sama je analiza tekstova i kategorizacija argumentacija podrazumijevala postavljanje svojevrsnih razgraničenja ili neku vrstu omeđivanja diskursa, a onda i neku vrstu rastezanja njihovih dosega. Međutim, valja imati na umu da su ta razgraničenja samo analitičkog tipa, i da su argumentacije u svojim naglascima kroz tekstove uvijek fluidne konstrukcije koje se kontinuirano premještaju unutar zamišljenog raspona bliskosti izjava $\mathrm{s}$ određenim pretpostavkama i argumentacijama koje karakteriziramo kao neoliberalne. U pozadini neodređenosti i teškoća svrstavanja diskurzivnih formacija u određene ideološke „ladice“, često se nalazi i strateška aproprijacija argumentacija koju provode sami kazivači u svrhu jačanja 
vlastite pozicije moći uvjeravanja, na što ukazuje i Sean Phelan (2007a, 2007b, 2014) kada govori o takozvanom eufemiziranom neoliberalnom diskursu kao i Bastiaan van Apeldoorn (2009) koji opisuje kombinaciju diskursa konkurentosti s diskursom socijalne kohezije, a sve s ciljem održavanja hegemonije neoliberalizma. S druge pak strane, sam je Friedrich A. Hayek u svojoj knjizi Ustrojstvo slobode (2011) iznosio istu sumnju naspram diskursa socijalne države, smatravši ju varljivim i fluidnim konstruktom koji predstavlja opasnost individualnoj slobodi:

„Trenutna je situacija uvelike izmijenila zadatak branitelja slobode i učinila ga mnogo težim. Dokle god je opasnost dolazila od socijalizma otvoreno kolektivističke vrste, bilo je moguće argumentirati da su načela socijalista jednostavno kriva: da socijalizam neće postići ono što socijalisti žele i da će proizvesti druge posljedice koje im se neće svidjeti. Mi ne možemo na sličan način argumentirati protiv socijalne države jer taj termin ne označava konačni sustav. Ono što se naziva tim imenom jest konglomerat toliko mnogo različitih i čak kontradiktornih elemenata da, dok neki od njih mogu slobodno društvo učiniti primamljivijim, drugi su s njime nekompatibilni ili barem mogu značiti potencijalnu prijetnju njegovu postojanju“" (Hayek 2011: 375).

U okvirima poststrukturalističke misli o diskursu kako ga je koncipirao Foucault, moguće je poteškoće u razgraničavanju diskurzivnih formacija pripisivati spontanim rekombinacijama argumentacija koje su integralna karakteristika svih diskurzivnih praksi. Teško se može procijeniti koji je diskurs dominantan u javnom diskursu te koji akteri zagovaraju koji diskurs s obzirom na međusobno prožimanje i interdiskurzivnu aproprijaciju. Ipak, možda je najprikladnije zamisliti poredak diskursa o fleksibilizaciji kao kontinuum, a svaki pokušaj kvantifikacije te formacije uvijek valja uzeti u obzir samo uvjetno. Pa tako imamo argumentacije koje se po nekim njihovim karakteristikama nedvosmislenije može povezati s neoliberalnom varijantom diskursa o fleksibilizaciji, ali ima i argumentacija koje imaju značajke koje ih približavaju „socijalnoj“ strani kontinuuma koja se suprotstavlja neoliberalnoj viziji odnosa na tržištu rada, a može se povezati s diskursom socijalne države naglašavajući negativne učinke fleksibilizacije i promičući inkluzivniju i socijalniju viziju tržišta rada. Diskurs ili argumentacija konkurentnosti, i s njome povezane argumentacije restrukturiranja i argumentacije individualne odgovornosti na tržištu rada najbliže su onome što bi Phelan (2007b) nazvao transparentnim neoliberalnim diskursom koji se temelji na retorici slobodnog tržišta. Skupine argumenata povezane $\mathrm{s}$ problemom nezaposlenosti i argumentacija modernizacije mogu biti u određenim aspektima povezane s neoliberalnim diskursom, ali imaju 
i neke značajke diskursa koji nisu nužno neoliberalnog karaktera, već su na neki način neutralne ili čak gravitiraju prema diskursu socijalne države, a dijelom ih se može podvesti pod ono što je Phelan opisao kao eufemizirani neoliberalni diskurs, odnosno kao blaža i prihvatljivija varijanta neoliberalnog diskursa koja je našla svoj izraz u diskursu Trećeg puta kao i u diskursu Europske Unije o socijalnom tržištu. U javnom su diskursu prisutne argumentacije oponirajuće neoliberalnom diskursu jer su nedvosmisleno usmjerene zagovaranju socijalnih zaštita; to su na primjer argumentacija koja fleksibilizaciju povezuje s rastom nesigurnosti i nejednakosti na tržištu rada kao i argumentacija politike javne potrošnje s ciljem pravednije raspodjele javnih sredstava kako bi se ublažile posljedice materijalnih nejednakosti, siromaštva i gospodarske krize.

Pri analizi tekstova o fleksibilizaciji tržišta rada deregulacijom, odnosno izmjenama Zakona o radu, pronađeno je nekoliko tipova argumentacija kojima zainteresirani akteri nastoje na neki način pojasniti, promovirati, legitimirati ili diskreditirati promjene u regulaciji tržišta rada. Kodiranjem prema temama ustanovljena je artikulacija desetak vrsta argumentacija koje se odnose na promjene Zakona o radu. Ti argumenti koji kruže u javnom diskursu opisuju očekivane učinke fleksibilnije uređenog tržišta rada, i s njima povezano iznošenje određenih preporuka o politikama na tržištu rada. Izdvojene preporuke moguće je prepoznati kao ideološki, odnosno interesno motivirane. Valjda naglasiti da i sami akteri u javnom diskursu prepoznaju ideološku obojenost argumentacija pojedinih aktera te katkad parafraziraju argumentacije pojedinih aktera ni bi li na njih odgovorili vlastitom logikom argumentiranja. U pojedinim se odlomcima mogu pronaći argumentacije za koje se može ustvrditi da podržavaju specifične politike fleksibilizacije.

Artikulacije spomenutih argumentacija odnose se na prisutnost opisa procesa promjena na tržištu rada koje se mogu podvesti pod pojam fleksibilizacije, načina na koje te promjene utječu na aktere na tržištu rada. Argumentacije povezane s fleksibilizacijom najvećim dijelom sadrže tvrdnje koje predstavljaju ideološki, odnosno interesno motivirane sudove o tome zašto je i kako fleksibilizacija korisna za hrvatsko gospodarstvo, poduzetničku klimu, a time i čitavo hrvatsko društvo. U javnom diskursu o fleksibilizaciji mogu se prepoznati elementi neoliberalnog diskursa o tržištu rada $\mathrm{u}$ formi artikulacija određenih argumentacija koji podrazumijevaju specifično viđenje tržišta rada $\mathrm{s}$ određenim stupnjem fleksibilnosti. Fleksibilizacija tržišta rada bi se trebala odvijati kroz deregulaciju, odnosno promjene u radnom zakonodavstvu koje bi olakšale poziciju kapitala na tržištu rada, prebacivanjem dijela troškova krize na same radnike. 
Analiza tema samih članaka ukazivala je na postojanje određenih vrsta argumentacija koje se mogu povezivati sa specifičnim stajalištima o procesu fleksibilizacije tržišta rada smanjenjem zakonske zaštite zaposlenja, odnosno deregulacijom radnog zakonodavstva. S obzirom na to da je bilo potrebno istražiti mogućnost dominacije neoliberalnog diskursa $u$ javnoj komunikaciji o fleksibilizaciji tržišta rada, u tekstovima su kodirane prethodnim iščitavanjem ustanovljene argumentacije na temelju prisutnosti odabranih riječi koje upućuju na elemente pojedinih diskursa. Sama prisutnost pojedinih riječi nije nužno označavala i identifikaciju s njima povezanog argumenta, već je bilo potrebno dodatno provjeriti smisao svake argumentacije detaljnijom analizom teksta prethodno izdvojenog prema kriteriju pojavljivanja određene riječi $u$ kontekstu značenja koje fleksibilizaciju, u terminima karakterističnima za svojstva prethodno opisanih diskursa, percipiraju u negativnom ili pozitivnom svjetlu. Kodiranju leksičkih jedinica pristupilo se uvažavajući kontekst u kojem se pojavljuju pojedine riječi ili sintagme. Sama pojava riječi koja može ukazivati na određenu diskurzivnu formaciju ne uzima se kao indikator nekog od spomenutih diskursa jer se pojedine leksičke jedinice mogu koristiti s različitim značenjima za same kazivače te s pozitivnim ili negativnim predznakom.

Prva argumentacija za kojom se poseže pri nastojanjima da se $\mathrm{u}$ javnosti proces fleksibilizacije prikaže pozitivnim jest percepcija „fleksibilnosti tržišta rada kao načina da se povećaju ulaganja podizanjem konkurentnosti”; skraćeno se može nazvati „argumentacijom konkurentnosti”. U javnom diskursu o fleksibilizaciji tržišta rada, prisutna je argumentacija da je fleksibilizacija tržišta rada kroz deregulaciju radnih zaštita jedan od nekoliko ključnih čimbenika koje određuju konkurentnost gospodarstva neke države. Argumentacija konkurentnosti predstavlja retoriku slobodnog tržišta koja pripada (transparentnom) neoliberalnom diskursu i koja pretpostavlja da bi se odnosi na tržištu rada trebali uređivati na način da se omoguće uvjeti tržišnog natjecanja otklanjanjem zakonske regulacije koja utječe na tržišno natjecanje. Transparentni neoliberalni diskurs najvećim se dijelom prepoznaje pojavljivanjem pojma „konkurentnosti”, odnosno „kompetitivnosti” koji se kada je riječ o supojavljivanju različitih pojmova s pojmom Zakona o radu ili pojmom fleksibilizacije u pojedinačnim jedinicama analize, odnosno pojedinačnim tekstovima značajno supojavljuje. U uzorku se u marginalnom omjeru izričito spominje pozitivni učinak djelovanja tržišnih mehanizama korištenjem sintagme ,slobodno tržište”, mada su konkurentnost i kompetitivnost pojmovi kojima se označava slobodno tržišno natjecanje. Argumentacijom konkurentnosti zagovara se proširenje slobode tržišta kojoj su izloženi poslodavci na sam rad, odnosno izmjene 
tržišta rada usmjerene su tako da budu podređene prioritetima konkurentnosti, odnosno tržišta. U argumentaciji konkurentnosti sadržana je i pretpostavka da kao što su poslodavci izloženi rizicima na tržištima na kojima nude svoje proizvode i usluge, jednako tako bi i radnici trebali biti izloženi rizicima koje donosi slobodno tržište, a to zapravo znači utemeljenje konkurentnosti kapitala, odnosno poslovnog uspjeha poslodavaca na jeftinijoj i manje zaštićenoj radnoj snazi. Argumentacija konkurentnosti također se može identificirati i kroz isticanje privlačenja stranih ulaganja kao argumenta za fleksibilizaciju tržišta rada, jer izrazi koji se često pojavljuju u analiziranim tekstovima iskazuju da bi se snižavanjem cijene rada poboljšala poduzetnička klima što privlači strani kapital. Iako ulaganje podrazumijeva potrošnju, pojam ulaganja razlikuje se od pojma potrošnje, osobito javne potrošnje, jer privatna ulaganja u ovom kontekstu podrazumijevaju povrat uloženog, a u nekim slučajevima i porezne olakšice za ulagače i poduzetnike.

Druga se vrsta argumentacija sastoji od toga da zagovaratelji fleksibilizacije i predlagatelj Zakona o radu kojim bi se trebala omogućiti fleksibilnost na tržištu rada, ističu da je navedeni proces smanjivanja zakonske zaštite radnika potreban, a kao razlog navode da regulacija tržišta rada otežava ili onemogućuje restrukturiranje privatnih poduzeća, odnosno provođenje strukturnih reformi državnih i javnih službi te državnih poduzeća. Fleksibilnost tržišta rada, odnosno deregulacija radnih odnosa shvaćena je kao instrument u rukama zakonodavca kojim se omogućuje racionalizacija troškova poduzeća, odnosno državna politika štednje. „Argumentacija restrukturiranja” ponajprije se odnosi na aspekt numeričke fleksibilnosti, to jest na omogućavanje poslodavcima da lakše daju otkaze, pa su ključne riječi koje se odnose na navedeni tip argumenta „restrukturiranje tvrtki”, „strukturne reforme”, „otkaz”, „,bolni rezovi”, ,potrošnja države” i slično. Argumentacija restrukturiranja povezana je s ekonomskom krizom te smanjenjem potrošnje i ekonomske aktivnosti što rezultira viškom radne snage kako u privatnom, tako i u javnom sektoru. Poslodavci nastoje smanjiti troškove rada smanjivanjem broja zaposlenih. Međutim, regulacija tržišta rada, odnosno radne zaštite poput na primjer otpremnina, čine otpuštanje skupljim od onoga što su poslodavci spremni prihvatiti.

Treći skup argumenata koji zagovaraju fleksibilizaciju odnosi se na tvrdnju da je deregulacija tržišta rada dobra za same radnike jer povećava slobodu radnika i proširuje njihove mogućnosti izbora na tržištu rada. Prema zagovornicima deregulacije tržišta rada, fleksibilnost koristi radnicima jer omogućuje povećanje vrijednosti njihova rada, poticanjem razvoja ljudskog kapitala. Ova argumentacija sadrži pretpostavku da će deregulacija tržišta rada i 
uvođenje veće fleksibilnosti u radne odnose poticati radnike da budu mobilni i prilagodljivi, čime se podrazumijeva da je to korisno samim radnicima, iako pojam ljudskog kapitala zapravo predstavlja naglašavanje karakteristika radnika u skladu s potrebama kapitala odnosno prema onome što je korisno samim poslodavcima. Treći skup argumenata možemo nazvati „,argumentacijom individualne odgovornosti”, a ključni pojmovi koji najčešće upućuju na prisutnost navedene argumentacije u analiziranim tekstovima jesu „cjeloživotno učenje“, „prilagodljivost“", „mobilnost“, „produktivnost“", „sloboda radnika“, „,mogućnost veće zarade”. Argumentacija ljudskog kapitala predstavlja dimenziju neoliberalnog diskursa kako ga je svojedobno u svojim predavanjima o neoliberalnom governmentalitetu identificirao i Michel Foucault (2008) i to prema tezama iz radova američkog neoliberalnog ekonomista Garyja Beckera koji je razvio teoriju ljudskog kapitala. U ovu argumentaciju mogu se uključiti i zahtjevi neoliberalnog poretka za radom na vlastitom usavršavanju i obrazovanju kako bi se radnici prilagodili potrebama poslodavaca, iako se to dodatno podređivanje radnika interesima poslodavca u neoliberalnom diskursu nastoji prikazati kao nešto što je dobro za radnike u vidu ulaganja u znanje i poboljšanja sposobnosti što rezultira ,jačanjem i rastom ljudskog kapitala“ (Stanford i Vosko 2004). Kroz ulaganja u vlastitu „konkurentnost“, radnici bi onda prema zaslugama i trudu mogli osigurati sebi bolji posao, to jest bolje uvjete kroz individualne pregovore s poslodavcem. U kontekstu ove argumentacije kolektivno se pregovaranje smatra nepravednim kako za poslodavce, zbog monopola sindikata koji utječu na cijenu rada, tako i za radnike čije se razlike u sposobnostima kolektivnim ugovorima poravnavaju (Jackson 2016). Zato je potrebno staviti što je veći mogući naglasak na individualno pregovaranje u kojem je radnik slobodan sam sebe zastupati i zauzeti se za vlastiti interes. Kolektivno se pregovaranje na taj način prikazuje preograničavajućim, i prema neoliberalnom shvaćanju znači neku vrstu nametanja odluka kolektiva pojedincu. Međutim, kako je ranije navedeno, poslodavac je uvijek u znatno moćnijem položaju od radnika na tržištu rada, a neoliberalna tvrdnja da je ugovorne odnose na tržištu rada najbolje prepustiti individualnim dogovorima između poslodavca i radnika pri čemu radnik ima priliku dogovoriti ono što njoj ili njemu najbolje odgovara, bez intervencije sindikata ili države, predstavlja primjer neoliberalnog tumačenja radnih odnosa i samog tržišta rada.

Četvrta vrsta argumentacije odnosi se na zagovaranje fleksibilizacije tržišta rada kao oblika suvremene i neizbježne organizacije radnih odnosa pretpostavljajući da bi ta promjena označavala modernizaciju radnih odnosa i nastavak procesa tranzicije Hrvatske u moderno kapitalističko društvo, odnosno „,argumentacija modernizacije”. Kod argumentacije 
modernizacije karakteristično je suprotstavljanje postojećeg Zakona o radu kao zastarjelog u odnosu na novopredloženi Zakon koji pak predstavlja kretanje odnosa na tržištu rada ukorak s vremenom. Stari je Zakon o radu u javnom diskursu o fleksibilizaciji označen kao „rigidan” i „,neprilagođen” duhu vremena, a tržište rada je, kao rezultat njegove primjene, postalo „zamrlo” ili „umrtvljeno”. Predloženi, izmijenjeni Zakon o radu opisuje se kao „moderan” i „liberalan” zakon koji bi trebao riješiti mnoge probleme na tržištu rada te bi prvenstveno postao usklađen sa zahtjevima suvremenog ekonomskog sustava utemeljenog na konkurentnosti i globalnim tržištima, ali i zahtjevima novih tehnologija i proširenju sektora usluga i njegova udjela $u$ stvaranju radnih mjesta na tržištu. U tom smislu su upravo u argumentaciji modernizacije isprepletene dvosmislene značajke fleksibilnosti pri čemu s jedne strane nije sporna potreba da se određeni aspekti regulacije tržišta rada trebaju prilagođavati tehnološkim i ekonomskim promjenama u društvu, međutim valja raspraviti na koji je način zamišljena reforma radnog zakonodavstva, ako je krajnji cilj osuvremeniti ga te vodi li se ta promjena i obzirom prema zaštiti radnika, a ne samo nastojanjima da se ,,poboljša poduzetnička klima“. Iz tog je razloga ova vrsta argumentiranja u jednom svom aspektu povezana s argumentacijom konkurentnosti jer povezuje snižavanje cijene rada i smanjivanje radnih zaštita s promjenama u strukturi plaćenog rada djelomično uvjetovanog objektivnim posljedicama tehnološkog napretka i globalizacije.

Argumentacija koja zagovara fleksibilnost tvrdeći da je regulacija tržišta rada ta koja uzrokuje visoku nezaposlenost i nisku zaposlenost u analizi je označena kao ,argumentacija rješavanja problema nezaposlenosti““. Ona se odnosi na zagovaranje fleksibilizacije tržišta rada zbog pretpostavke da u prevelikoj mjeri regulirana tržišta rada u uvjetima globalne ekonomije imaju tendenciju visoke stope nezaposlenosti i niske stope zaposlenosti te segmentacije tržišta rada. Ostvarivanje fleksibilnosti radnih odnosa koje se provodi deregulacijom tržišta rada omogućuje otvaranje novih radnih mjesta i zadržavanje postojećih te na taj način pozitivno djeluje na povećanje broja zaposlenih. U kontekstu argumentacije povezane s nezaposlenošću, kolokacije koje ukazuju na prisutnost navedene argumentacije jesu „radna mjesta”, „prepreke zapošljavanju”, „mladi i visokoobrazovani”, „,nezaposleni”, ,privremeni rad”, „,segmentacija“.

U javnom diskursu također se pojavljuje argumentacija koja se ne odnosi toliko na neku tvrdnju kojom bi se u ekonomskom smislu opravdalo provođenje fleksibilizacije deregulacijom fleksibilizacija tržišta rada, već je fleksibilizacija shvaćena kao dio politika koje su važne za postizanje ciljeva koji su zajednički interes čitave zemlje; to jest zajednički i poslodavcima i radnicima. Dapače, u kontekstu spomenute argumentacije, fleksibilizacija tržišta rada zahtijeva 
široki konsenzus svih dijelova društva jer je ona dio nacionalnog interesa. U središtu navedene argumentacije naglasak je na jedinstvu zajedničkog, odnosno nacionalnog interesa poslodavaca i radnika, a time i čitavog hrvatskog društva, pa je za fleksibilizaciju ključno održavati tripartitni, odnosno socijalni dijalog čime se postiže konsenzus između (socijalnih) partnera o provođenju fleksibilizacije tržišta rada deregulacijom. Argumentacija zajedničkog nacionalnog interesa traži konsenzus svih članova društva oko predloženih mjera fleksibilizacije koje bi trebale proizvesti određene učinke koji su u diskursu ocijenjeni kao poželjni i pozitivni, a to su na primjer privlačenje stranih ulaganja, smanjivanje nezaposlenosti, poticanje radnika na cjeloživotno učenje u svrhu ulaganja u ljudski kapital, a time i ,,jačanje” konkurentnosti radnika na tržištu rada.

U tekstovima je prisuta i argumentacija koja se odnosi na viđenje odnosa između radnika i poslodavaca, a u suprotnosti je s ranije spomenutom argumentacijom zajedničkog, odnosno nacionalnog interesa. Argumentacija nacionalnog interesa temelji se na pretpostavci da je ono što je dobro za poslodavce dobro i za radnike, ali i društvo u cjelini te da između radnika i poslodavaca nema pravog sukoba interesa. Argumentacija koja upravo u suprotnosti s prethodnim tvrdnjama o jedinstvu interesa stavlja naglasak na sukob interesa između poslodavaca i radnika može se nazvati ,argumentacijom sukoba interesa između poslodavaca i radnika“. Akteri koji se služe spomenutom argumentacijom drže da ukoliko se zahtijevaju ustupci jedne strane, odnosno radnika, u smjeru fleksibilizacije, onda to valja popratiti ustupcima koji podrazumijevaju odricanje od određenih interesa na drugoj strani, odnosno na strani poslodavaca. Dinamika sukoba interesa između sindikata i poslodavaca u javnom diskursu o fleksibilizaciji tržišta rada ukazuje na nemogućnost postizanja konsenzusa jer se predložena deregulacija usmjerava na olakšavanje poslovanja, odnosno fleksibilizaciju koja većinom koristi poslodavcima. Istovremeno, pozitivni pomaci za poslodavce, za radnike predstavljaju smanjivanje prava i zaštita koje nisu nadomještene odgovarajućim ustupcima od kapitala. U samom javnom diskursu, doduše, nisu artikulirani detalji što bi taj kompromis trebao obuhvaćati, već je u prvom planu isticanje same činjenice da je sukob interesa prisutan i da se fleksibilizacija kao zajednički, nacionalni interes, ne može uzimati zdravo za gotovo. U tom je smislu upitan temeljni smisao socijalnog dijaloga i socijalnog partnerstva kao sredstva postizanja stvarnog kompromisa oko predloženih politika. Isticanje nemogućnosti postizanja konsenzusa između rada i kapitala partnerstvom kroz dijalog, odnosno nemogućnosti uravnoteženja zahtjeva kapitala $\mathrm{s}$ nastojanjima organiziranog rada, povezano je $\mathrm{s}$ radikalizacijom prijepora oko predloženih izmjena, pa su riječi koje se povezuju s 
argumentacijom sukoba interesa između poslodavaca i radnika, i koje upućuju na navedenu argumentaciju, ali ovisno o kontekstu; „,socijalni dijalog”, „konsenzus”, ,štrajk”, ,prosvjed sindikata" i slično.

„Argumentacijom o nesigurnosti radnika na fleksibilnom tržištu rada“ u javnom se diskursu ukazuje se na to da je poslodavac u odnosu na radnika u moćnijoj poziciji na tržištu rada, ukoliko zaštitu radnika ne osiguravaju institucije tržišta rada reguliranog radnim zakonodavstvom, ali i članstvo u sindikatima. Bez adekvatnih zaštita i garancija na tržištu rada, radnik je izložen tržišnim mehanizmima koje poslodavac zbog svoje jače pozicije može okretati u vlastitu korist i to ponajprije snižavanjem cijene rada, a posljedično čak i iskorištavanjem radnika, što može rezultirati porastom socijalnih nejednakosti. Ključne jedinice značenja koje upućuju na argumentaciju slabije pozicije radnika u javnom diskursu sastoje se od sintagmi „rušenje cijene rada”, „nesigurnost”, ,iskorištavanje” i slično.

„Argumentaciju politike potrošnje“ čine tvrdnje koje se temelje na kejnzijanskoj ekonomici kao načinu kreiranja ekonomskih politika, u koje se između ostalog ubrajaju i politike na tržištu rada. Argumentacija politike potrošnje predstavlja oponirajući moment u javnom diskursu koji se suprotstavlja neoliberalnom zagovaranju politike štednje i restrukturiranja kao odgovora na gospodarsku krizu, ali i krizu na tržištu rada. Nasuprot neoliberalnim načelima poduprijete politike štednje, zagovornici kejnizijanizma i socijalne države traže ekonomski rast utemeljen na poticanju potrošnje, pri čemu je naglasak na smanjivanju socijalnih nejednakosti, većim pravima i zaštiti radnika te labavijoj fiskalnoj, pa čak i monetarnoj politici. U kontekstu javnog diskursa o fleksibilizaciji tržišta rada, nalazimo tvrdnje da fleksibilizacija tržišta rada, osobito aspekti koji se odnose na olakšavanje otpuštanja radnika i restrukturiranje, neće proizvesti željene ekonomske ili socijalne učinke, već je za smanjivanje nezaposlenosti i ekonomski napredak potrebno raditi na povećanju potrošnje. Ključna riječ koja ukazuje na argumentaciju politike potrošnje u diskursu o fleksibilizaciji tržišta rada jest „poticanje potrošnje“ ili pak „,socijalna država“ te „,kejnzijanizam“.

\subsubsection{Neoliberalni diskurs konkurentnosti}

Neoliberalni diskurs konkurentnosti moguće je poistovjetiti s transparentnim neoliberalnim diskursom kojim se zagovara ekonomska učinkovitost koja proizlazi iz mehanizama po mogućnosti što slobodnijeg tržišta rada (Phelan 2007a, 2007b, 2014; Van Apeldoorn 2009). U javnom diskursu o fleksibilizaciji ističe se postizanje konkurentnosti na više razina kao jedan od najvažnijih razloga deregulacije tržišta rada, odnosno fleksibilizacije 
radnih odnosa. U neoliberalni diskurs konkurentnosti također možemo smjestiti i diskurs o restrukturiranju koja je dio politike štednje, a zagovara olakšavanje otpuštanja te diskurs, odnosno argumentaciju individualne odgovornosti na tržištu rada.

Dio neoliberalnog diskursa kojeg nalazimo u javnom diskursu o fleksibilizaciji tržišta rada jest tvrdnja da je fleksibilizacija tržišta rada deregulacijom nužna kako bi se stvorili uvjeti za poboljšanje konkurentnosti, poboljšanje poduzetničke klime s ciljem poticanja ili privlačenja domaćih i stranih ulaganja. Neoliberalni diskurs konkurentnosti tržište rada primarno shvaća slično kao tržište roba te pretpostavlja da se gospodarski problemi, kao i problemi tržišta rada, mogu rješavati smanjivanjem regulacije tržišta rada, koje bi se onda tom deregulacijom što je više moguće približilo slobodnom tržištu. Dakle, u okviru argumenta konkurentnosti, omogućavanje nesputanog tržišnog natjecanja je sve što je potrebno za optimalno funkcioniranje tržišta rada, dok se u drugi plan postavlja činjenica uklopljenosti tržišta rada u društvene odnose, njegova uloga društvene integracije, slabija pozicija radnika na tržištu u odnosu na poslodavca te uvažavanje potrebe za sindikalnim udruživanjem rada kao odgovora na inherentnu pristranost tržišta rada u korist kapitala. Pojam „konkurentnosti” nalazimo u kontekstu pozitivnih tvrdnji da fleksibilno tržište rada ostvareno deregulacijom omogućuje bolju konkurentnost gospodarstva koja onda pozitivno djeluje na privlačenje stranih ulaganja, kvalitetu, proizvodnju, produktivnost i mogućnosti zaduživanja države. Dakle, ključna riječ koja se pojavljuje u kontekstu retorike slobodnog tržišta u diskursu o fleksibilizaciji jest „konkurentnost”, odnosno „kompetitivnost”, uz zagovaranje „dovođenja tržišta u radne odnose". Neoliberalni diskurs konkurentnosti artikuliran je s ciljem obrazlaganja i opravdanja politike fleksibilizacije s posebnim naglaskom na stvaranje ,povoljnije poduzetničke klime” koja će navesti poduzetnike na ulaganja i privući strane investitore što podrazumijeva da se deregulacija tržišta rada treba odvijati na način da dovodi do fleksibilnosti koja najvećim dijelom pogoduje poslodavcima. U sljedećem primjeru dan je izvadak iz teksta rubrike „HUP komentar“ redovito objavljivane u sklopu Večernjeg lista, a jasno pokazuje sažete zahtjeve poslodavaca koje je u komentaru predstavio glavni direktor HUP-a, Davor Majetić. U Majetićevu je shvaćanju fleksibilizacije tržišta rada sadržan sukus neoliberalnih argumenata koja se zasnivaju na argumentaciji konkurentnosti na temelju jeftinije radne snage:

Mala i srednja poduzeća moraju postati fokus ekonomskih politika $i$ rasprava. U tom smislu potrebno je zakonom utvrditi fleksibilniji tretman malih $i$ srednjih poduzeća za koje je fiksni trošak radne regulacije veći nego za velike 
tvrtke. Tako bi sukladno preporukama EU trebalo zaštititi male $i$ srednje poduzetnike kod zapošljavanja na određeno vrijeme, ali i postupaka otpuštanja radnika. Velika bi im pomoć bio obračun PDV-a po naplaćenoj realizaciji za sve članice sustava PDV-a s ukupnim prihodom manjim od 2 milijuna kuna. Njihovo porezno rasterećenje bi povećalo konkurentnost cijelog hrvatskog gospodarstva. Smanjenje tereta neporeznih nameta poduzetnika na polovicu bio bi najveći doprinos za svaku hrvatsku obitelj. Sigurno bi im pomoglo i postupno smanjenje opterećenja rada (ali i kapitala), pri čemu bi prva mjera trebala biti podizanje granica poreznih razreda i/ili smanjenje stopa poreza na dohodak. Ranije spominjano radno zakonodavstvo mora u svom cilju imati povećanje zaposlenosti $s$ olakšanim postupcima zapošljavanja $i$ otpuštanja, prilagodljivim radnim vremenom, drugačijom definicijom minimalne plaće (kroz sektorske kolektivne ugovore). Rigidnost radnog zakonodavstva jedan je od elemenata odvraćanja investitora od ulaganja u Hrvatsku. Posebna cjelina je obrazovanje i posljedično znanje $i$ vještine. To je prvi preduvjet konkurentnosti.

(Davor Majetić, Večernji list, 5.12.2013.)

Argumentacija konkurentnosti pripada transparentnom neoliberalnom diskursu slobodnog tržišta, a akteri koji posežu za tim argumentom u javnom diskursu, izravno identificiraju fleksibilizaciju tržišta rada kao smanjivanje sigurnosti radnika i radnih zaštita i to sa svrhom ostvarivanja bolje poduzetničke klime koja, između ostalog osigurava privlačenje stranih investicija, i to konkretno mjerilima kao što su svjetske ljestvice konkurentnosti, između ostalog i ona Svjetske banke, ili indeks zakonske zaštite zaposlenja (EPL indeks) OECD-a.

U okviru spomenute argumentacije „konkurentnost“ se ovisno o kontekstu može razlikovati prema nekoliko razina, pa se tako na najvišoj razini spominje konkurentnost Hrvatske u usporedbi s ostalim zemljama Europske Unije, pa čak i u globalnom kontekstu te osobito u usporedbi sa susjednim zemalja kao što su Makedonija ili Srbija.

Premijer Zoran Milanović podsjetio je da je Njemačka prije deset godina imala veliku nezaposlenost, „čega se danas malo tko više sjeća”, ali je potom provela reforme na tržištu rada i danas ima konkurentnije gospodarstvo.

(Z. Milanović prema R. Kovačević Barišić, M. Špoljar, Večernji list, 24.1.2014.) 
(...) najrazvijenije države Europske unije koje su već tada bile daleko ispred nas po razvijenosti radnih odnosa, tražile su dalje kako da razvijaju radno zakonodavstvo u smjeru zapošljavanja, rasta i konkurentnosti.

Tako smo prošli tjedan imali prilike razgovarati sa stručnjacima iz područja radnog zakonodavstva, predstavnicima europskog gospodarskosocijalnog odbora iz Austrije, Velike Britanije i Portugala. Njihovi komentari na naše radno zakonodavstvo bili bi zabavni da nisu pa recimo to tako - tragični. Uzmimo na primjer Austriju, na čije se zakonodavstvo često pozivaju sindikati. Austrija, o čijem se modelu sustavu otpremnina upravo pregovara u Hrvatskoj ima i svoju drugu stranu. Tamo se otkaz ne mora obrazlagati, poslodavac može otkazati ugovor o radu ne obrazlažući razloge, bez bojazni da će neki sudac na sudu, nakon što prođu tri godine, smatrati da odluka i razlozi poslodavca nisu dovoljni. Radno vrijeme je fleksibilno, nešto što u Hrvatskoj još ne postoji, a stanka radnicima ne ulazi u radno vrijeme $i$ nitko to ne smatra napadom na radnička prava. Radnici rade u prosjeku osam sati, a pauza od pola sata im nije plaćena i ne ulazi u radno vrijeme. Na taj način svaki radnik u Austriji godišnje radi 120 sati više od našeg radnika, a ne moram reći koliko to utječe na produktivnost.

Veliku Britaniju bolje je na ovim prostorima i ne spominjati. Imaju veliki broj različitih netipičnih načina zapošljavanja koje mi ne možemo niti smisliti a kamoli provesti. Tako na primjer imaju „zero-hours agreement“ - ugovor koji sklapaju radnik i poslodavac ne znajući koliko će radnik biti potreban poslodavcu niti je poslodavac dužan naznačiti to u ugovoru. Radnik je pripreman da radi. No s druge strane radnik nije obavezan prihvatiti posao kad mu ga poslodavac nudi. Radno vrijeme u Velikoj Britaniji izrazito je fleksibilno s time da su oni uveli i „,optout “ odnosno mogućnost da se radnika, uz njegov pristanak ne odnose ograničenja vezana za radno vrijeme i odmore (...)

(Nataša Novaković, HUP komentar, Večernji list, 17.10.2013.)

Kada se govori o konkurentnosti hrvatske države, spominje se također i porezna konkurentnost. U spomenutom se kontekstu privlačnosti Hrvatske za investiranje u usporedbi s drugim zemljama, naglašava važnost donošenja novog Zakona o radu. Novim Zakonom o radu provela bi se deregulacija tržišta rada sa svrhom fleksibiliziranja radnih odnosa što bi 
prema zagovarateljima fleksibilizacije imalo pozitivan utjecaj na hrvatsku ekonomiju jer bi poslovanje bilo olakšano nižim troškovima rada u odnosu na druge zemlje konkurente. Navodi se važnost postizanja konkurentnosti pojedinih kompanija i malih i srednjih poduzetnika, koji zbog previsoke cijene rada i visokih radnih zaštita ne mogu smanjivati cijenu svojih proizvoda i usluga kako bi se mogli natjecati s drugim kompanijama na zajedničkom europskom tržištu.

Da bismo imali konkurentan proizvod na svjetskom tržištu, za proizvodnju u Hrvatskoj trebaju resursi, znanje, jeftina energija, niska cijena kapitala, jeftina radna snaga i niski porezi. Mnogo toga nemamo. Ne budemo li konkurentni, $i$ dalje ćemo gubiti tržišta i radna mjesta. Zato ne razumijem naše sindikate: oni se bore za prava radnika i poskupljuju rad, ruše konkurentnost, dok se ne ugasi $i$ zadnje radno mjesto. Oni u vezi s tim moraju imati mjeru.

(Branko Roglić, prema N. Jelić, Jutarnji list, 1.10.2013.)

Da bi brojevi štimali potrebno je napraviti puno više od kampanja i ofenziva. Za početak - izmijeniti Zakon o radu. Na način koji će naše tvrtke učiniti konkurentnijim, što god sindikalne narikače na putu prema vlastitim foteljama $u$ Saboru vikale.

(Borislav Škegro, Večernji list, 19.10.2013.)

U tom kontekstu, na primjer, Deakin i Wilkinson (1994), naglašavaju protuargument koji je u skladu s principima kejnzijanske ekonomike. Naime, u uvjetima konkurencije i slobodnog tržišta moguće je graditi konkurentnost na drugim aspektima koji čine sastavni dio poslovanja, a snižavanje troškova smanjivanjem materijalnih prava radnika nije osobit znak sposobnog vođenja kompanije. Naime, ukoliko države fleksibilizacijom tržišta rada omoguće snižavanje troškova rada, takva vrsta prednosti kompanija u odnosu na druge zapravo destimulira inovacije i druge aspekte poslovanja koji se trebaju poboljšavati kako bi se neka tvrtka mogla natjecati s drugim kompanijama u njezinu okruženju. U okviru neoliberalne ekonomske paradigme, zemljama u razvoju se nastoji omogućiti natjecanje s ekonomski razvijenim državama snižavanjem cijena rada, na što međunarodne organizacije poput Međunarodnog monetarnog fonda ili Svjetske banke te drugi zagovaratelji fleksibilnosti tržišta rada gledaju kao na priliku 
da manje bogate zemlje počnu dostizati ekonomski razvijenije zemlje, kao što se može prepoznati u sljedećem primjeru argumenta iz javnog diskursa:

Zakon o radu. Procjena je Svjetske banke da je hrvatsko radno zakonodavstvo nefleksibilno s visokim proceduralnim troškovima otpuštanja u odnosu na druge zemlje. World Competitiveness indeks po tome Hrvatsku rangira među 20 najgorih zemalja na svijetu. Preporuke svjetskih organizacija uvijek se vrte oko nižih troškova otpuštanja, fleksibilnijeg radnog vremena, reforme zakonske regulacije zapošljavanja te rigidnosti plaća utvrđenih kolektivnim ugovorima.

(Vuk Vuković, Jutarnji list, 28.12.2013.)

Međutim, ukoliko poslodavci u pojedinoj zemlji počnu temeljiti svoju konkurentnost isključivo na niskoj cijeni rada, dugoročno takav sustav može proizvesti suprotan učinak i naštetiti konkurentnosti tvrtke. Deakin i Wilkinson (1994) pišu da ovakvo iskorištavanje prednosti jeftine radne snage u stvarnosti dovodi do zatajenja tržišne konkurencije, jer umjesto da oni koji nisu dovoljno sposobni opstati na tržištu zbog lošeg poslovanja propadnu, oni zapravo uvijek imaju mogućnost troškove loših odluka ili nestručnosti i nesposobnosti prebacivati na radnu snagu. U skladu s navedenim, na tržištu opstaju poduzeća koje bi možda mnogo ranije nestala s tržišta da im niski troškovi rada ne omogućavaju opstanak. Kada raspravljaju o mogućnostima nadnacionalne regulative europskog tržišta rada, Deakin i Wilkinson ističu da protivnici uvođenja univerzalne nadnacionalne radne zaštite, u spuštanju troškova rada deregulacijom i fleksibilizacijom vide način da ekonomski manje razvijene države Europske unije pokušaju dostići bogatije članice. Međutim, kao što je već navedeno, temeljiti konkurentnost na spuštanju troškova rada otvara prostor disfunkcijama u drugim dimenzijama poslovanja što dugoročno može naštetiti kako kompanijama tako i manje razvijenim državama članicama, a koje u konačnici utječu i na smanjivanje konkurentnosti (Esping-Andersen i Regini 2000).

Treći oblik konkurentnosti koji se spominje odnosi se na konkurentnost radnika pri čemu se pretpostavlja da će ta konkurentnost, artikulirana u diskursu kao poželjna i pozitivna osobina, porasti na fleksibilnijem tržištu rada zbog izlaganja radne snage silama konkurencije i mehanizmima slobodnog tržišta. 
Naime, u dinamičnom i kompetitivnom okruženju, sigurna radna mjesta više ne postoje, a zaposlenici trebaju postati svjesni da opstanak leži u njihovim osobnim znanjima, vještinama $i$ sposobnostima te da su svakodnevno lako zamjenjivi.

(Alka Obadić, prema: G. Galović, Jutarnji list, 7.11.2013.)

U Hrvatskoj se svega 2,3 posto odrasle populacije u dobi od 25 do 64 godine na neki način obrazuje ili usavršava. Manje osoba koje sudjeluju u cjeloživotnom učenju, koje je jedini način da si osiguraju konkurentnost na tržištu rada, imaju samo Bugarska i Rumunjska. Najbolje pak stoji Danska u kojoj čak 32,3 posto odrasle populacije sudjeluje u cjeloživotnom učenju.

(Gordana Galović, Jutarnji list, 1.6.2013.)

Kao jedan od oblika konkurentnosti koji se spominje u javnom diskursu jest konkurentnost društvenih odnosa. Sintagma „konkurentnosti društva“ može biti zanimljiva ukoliko se protumači kao neka vrsta nadređivanja ekonomskih relacija svim drugim društvenim odnosima, međutim s obzirom na to da se koncept „konkurentnosti društva“ nalazi svega par puta u analiziranim tekstovima, moguće ju je pripisati općem i vrlo čestom korištenju pojma konkurentnosti u kontekstu reformi s ciljem nadvladavanja gospodarskih neprilika tijekom krize pa je to pojam za kojim se poseže bez mnogo promišljanja.

S pojmom konkurentnosti kompanija i države povezana je i argumentacija koja fleksibilizaciju tržišta rada vidi ključnim čimbenikom ekonomskog uređenja neke države koji omogućuje procese restrukturiranja, odnosno strukturnih reformi. U tekstovima se proces restrukturiranja povezuje sa situacijom gospodarske krize te temom politike štednje (takozvanog austeriteta). U analiziranim tekstovima pojavljivanje argumenta olakšavanja restrukturiranja kao legitimacije deregulacije i fleksibilnosti može se odnositi na privatni sektor ili na javni sektor, odnosno na restrukturiranje tvrtki ili restrukturiranje javnog ili državnog sektora što se označava i kao ,provođenje strukturnih reformi“. Pod restrukturiranjem se, između ostalog, najčešće podrazumijeva smanjivanje broja zaposlenika, kako u privatnim tvrtkama tako i javnim službama, pri čemu je važeći Zakon o radu percipiran kao prepreka koja poskupljuje otpuštanje radnika. 
U privatnom sektoru se restrukturiranje legitimira na način da se otpuštanje nastoji prikazati kao nešto na što se poslodavci vrlo teško odlučuju i to samo u slučajevima kada im je kompanija na rubu bankrota te kada su otkazi zapravo jedini spas koji poslodavce dijeli od stečaja i okončanja poslovanja. U okviru navedene argumentacije jednim od uzroka propasti kompanija smatra se i prekomjerna reguliranost tržišta rada. Pretpostavka koja stoji iza ovakve implikacije jest ta da zbog preskupog otpuštanja radnika, poslodavci nemaju mogućnost smanjivati broj zaposlenih, pa troškovi rada ostaju isti dok prihodi padaju, što dovodi do gomilanja gubitaka te naposljetku do gašenja tvrtke. Primjer opravdanja izmjena Zakona o radu u smjeru olakšavanja procedure otpuštanja, izjava je ministra Miranda Mrsića, koja se u nekolika navrata pojavljuje među analiziranim tekstovima, pri čemu je u nekima čak i obrazloženo da se restrukturiranje poduzeća smatra ujedno i zaštitom radnika, odnosno radnih mjesta, jer će otpuštanjem dijela radnika, opstati ,zdravi dio tvrtke”.

„Jasno je da promjene Zakona o radu neće otvoriti radna mjesta, to će učiniti investicije, dotok kapitala i povećanje konkurentnosti. Promjena zakona je nužna da bi se omogućilo lakše restrukturiranje poduzeća, ali i zaštitu radnika”, kazao je ministar rada i mirovinskog sustava Mirando Mrsić.

(Mirando Mrsić prema: Lj. Gatarić, Večernji list, 14.9.2013.)

Osim isticanja potrebe ostvarivanja konkurentnosti, Branko Roglić naglašava potrebu za olakšavanjem otpuštanja zaposlenika kako u državnom sektoru, tako i u privatnom sektoru, odnosno otpuštanje „loših” radnika kako bi se napravilo mjesta „dobrim” radnicima, iako u pozadini smanjivanja broja zaposlenih kojima plaće isplaćuje država stoji nastojanje da se smanje porezi poduzetnicima:

Prvo treba smanjiti poreznu presiju, a za to je preduvjet restrukturiranje države. Hrvatskoj treba predstečajna nagodba, hitno je moramo restrukturirati, jer ne možemo plaćati 20 župana, 570 načelnika općina, njihove zamjenike $i$ tajnice. (...)

U svim državama u kojima poslujem veća je fleksibilnost radne snage nego u Hrvatskoj. Zakon o radu mora priznati jednu veliku istinu: da je poslodavcu 
najvažniji dobar radnik. Poduzetnik se nikada neće odreći dobrog radnika. I zato ne treba zakonom štititi dobrog radnika. Zakonom o radu se štite loši radnici, a s njima nitko neće razviti poduzeće i napredovati. (...)

Smeta mi to što moji radnici, koji su dobri radnici, posredno moraju plaćati i loše radnike koje štiti zakon.

(Branko Roglić, prema N. Jelić, Jutarnji list, 1.10.2013.)

Kao dio neoliberalnog diskursa konkurentnosti možemo smatrati i argumentaciju restrukturiranja koja se odnosi na smanjivanje broja zaposlenih u državnom ili javnom sektoru, što se u diskursu često povezuje i sa smanjivanjem birokracije, ili smanjivanje administracije. Naime, u diskursu se tvrdi da bi se time s jedne strane olakšalo poslovanje tvrtki jer bi se neposredno smanjile procedure koje poslodavci trebaju prolaziti kako bi ostvarivali svoje poslovne ciljeve (takozvano „smanjivanje administrativnih barijera“), dok bi dugoročna posljedica bilo smanjenje potrebe za državnim i javnim službenicima što bi rasteretilo državni proračun i na taj način omogućilo smanjivanje poreznog opterećenja. Svi navedeni ciljevi restrukturiranja zapravo su u skladu s politikom štednje i smanjivanja troškova države, odnosno uvođenjem discipline $u$ državnu potrošnju $\mathrm{s}$ ciljem smanjivanja deficita te fiskalne konsolidacije koja je uvjetovana zahtjevima Europske komisije, odnosno ugovorom iz Maastrichta. Da bi država opravdala svoje troškove u kontekstu politike štednje ona se mora prema argumentu restrukturiranja voditi prema načelima učinkovitosti i profitabilnosti. Drugim riječima, državu treba voditi ekonomistički, kao poduzeće. U svom djelovanju država treba posebno voditi računa o tome da primarno pruža usluge osiguravanja olakšanog poslovanja za privatne poduzetnike; ona ga treba podržavati i podupirati, ali ujedno treba i sama biti uređena po uzoru na neku kompaniju u privatnom sektoru. Također je u javnim diskursu često istaknuto da su radnici previše zaštićeni. U neoliberalnom diskursu konkurentnosti zadržavanje „loših“ radnika u tvrtkama negativno utječe na produktivnost i dovodi do lošijeg poslovanja.

$\mathrm{U}$ argumentaciju restrukturiranja pripada i zagovaranje strukturnih reformi države koje podrazumijevaju da je fleksibilizacija tržišta rada potrebna kako bi se smanjili troškovi javnog i državnog sektora, između ostalog i primjenom novog i fleksibilnijeg Zakona o radu na državne i javne službenike. Naime, na državne se službenike odnosi poseban Zakon o državnim službenicima, a i državni i javni službenici pokriveni su kolektivnim ugovorima. Tu je prisutna i argumentacija politike štednje pri čemu se novopredloženi Zakon o radu uzima kao instrument 
smanjivanja prava radnika u državnom i javnom sektoru, s osobitim naglaskom na olakšavanje otkaza u navedenim sektorima. Unutar ovog argumenta prisutna je artikulacija nužnosti smanjivanja troškova države zbog procedure prekomjernog deficita, smanjenja „kreditnog rejtinga“, ali ponajprije zbog izjednačavanja položaja radnika u privatnom i javnom, odnosno državnom sektoru, za koje se smatra da nisu preuzeli dovoljan „dio tereta krize“. U okviru navedene argumentacije prisutna je pretpostavka da su zaposlenici u javnom sektoru previše zaštićeni $u$ odnosu na one $u$ privatnom sektoru te nalazimo artikulaciju samorazumljivosti potrebe svođenja prava zaposlenika javnog sektora na razinu privatnog sektora kao odgovora na gospodarsku krizu u Hrvatskoj.

U sljedećem primjeru može se prepoznati artikulacija argumentacije restrukturiranja, $u$ kojoj se deregulacija tržišta rada smatra jednim od politika koje bi trebale pokrenuti smanjivanje prava u javnom sektoru s obzirom na pretpostavku da je u njemu previše zaposlenih koji opterećuju državni proračun.

Možda su upravo sada u ovako dubokoj krizi trebali iskoristiti priliku za diferenciranje javnog i privatnog sektora. Javni je sektor taj koji treba dodatno racionalizirati, učiniti ga manjim i učinkovitijim. Privatni sektor ionako posluje na vjetrometini okrutnog tržišta, u privatnim tvrtkama s problemima radnici ionako nemaju adekvatnu zaštitu, a sada će im se ta zaštita dodatno smanjiti, dok će ovi iz predebelog i tromog javnog sektora tu novu egzistencijalno-socijalnu dramu promatrati nezainteresirano. Prava je istina da se to smanjivanje prava na javni sektor uopće neće odnositi. Ironija je sudbine da su mnoge privatne tvrtke žrtve ne samo svoje poslovne politike nego i lošeg poslovnog okruženja, prevelikog tereta javnog sektora.

(Gojko Drljača, Večernji list, 17.1.2013.)

Kao prepreka izjednačavanju prava i zaštite radnika između privatnog i javnog sektora smatraju se sindikati, koji pretežno pokrivaju upravo zaposlenike u javnim i državnim službama, koji se u diskursu ionako smatraju pretjerano zaštićenima u odnosu na privatni sektor. Argumentacija politike štednje nedvosmisleno pripada neoliberalnom diskursu koji zagovara austeritet i smanjivanje uloge države koja pruža široki raspon javnih usluga, koje prema neoliberalnim premisama trebaju biti u što većoj mjeri prepuštene privatnom sektoru, 
odnosno tržištu. Ova je argumentacija preskriptivna te u sebi sadrži i artikulaciju propisivanja postupaka vlasti u kontekstu navedene potrebe za smanjivanjem troškova države, pa se susreće i artikulacija preporuke da vlast, odnosno pojedini ministri, trebaju ignorirati kolektivne akcije sindikata. Naglašava se pretpostavka da postojeći Zakon o radu štiti jedino radnike u javnom sektoru, dok se u privatnom sektoru kompanije ne pridržavaju Zakona o radu i ne poštuju zakonom propisana prava i zaštite radnika.

S transparentnim neoliberalnim diskursom mogu se neposredno povezati i argumenti koji zagovaraju fleksibilizaciju tržišta rada pod pretpostavkom je ona dobra za radnike jer omogućuje veću slobodu odlučivanja radnika o poslu i poticanje radnika da sami usmjeravaju put svoje karijere poboljšavajući svoja znanja i vještine te da vlastiti rad koji nude na tržištu počnu smatrati oblikom kapitala. Fleksibilizacija tržišta rada na taj način potiče radnike da sami stvaraju oblike zaštite od nesigurnih uvjeta na tržištu rada, tako da povećavaju razinu svoje zapošljivosti, lakše nalazeći neki drugi posao. U kontekstu tržišta rada, naglašavanje individualnih stremljenja radnika nasuprot organiziranju rada, odnosno udruživanju u sindikate, zapravo predstavlja promicanje ideje da se rizici zatajenja na tržištu rada koje su zbog njegove uklopljenosti u šire društveno-ekonomske tokove zapravo problem cjelokupnog sustava, mogu prebacivati na pojedinačne radnike $U$ okviru ove argumentacije također je prisutno isticanje mogućnosti rada za više poslodavaca, na više poslova čak i preko uobičajenog ograničenja radnog vremena ne bi li radnik imao mogućnost sebi osigurati veća primanja. Iako na prvi pogled navedena pretpostavka koja stoji iza ovakve tvrdnje da fleksibilizacija na ovaj način koristi radnicima, izgleda kao pozitivan scenarij za radnike, ona zapravo nije uvjerljiva jer se njome legitimira postupna deregulacija koja najčešće predstavlja upravo provedbu snižavanja cijene rada i smanjenja sigurnosti radnog mjesta na tržištu rada. Zato je paradoksalno ustvrditi da se izlaganjem radnika tržišnim mehanizmima u kojima poslodavci imaju snažniju poziciju, stvara neku vrsta zaštite radnika, koji su na taj način primorani preuzimati individualne rizike promjene posla, troškove ulaganja u vještine i cjeloživotnog učenja ili pak preuzimanje rizika rada prekomjernog broja sati da bi se ostvarila neka materijalna potreba, kao što je na primjer otplaćivanje kredita.

Argumentacija individualne odgovornosti ukazuje na to da fleksibilizacijom tržišta rada deregulacijom dolazi do smanjivanja nesigurnosti na tržištu rada. Ovdje se polazi od pretpostavke da su radnici zaštićeni djelovanjem sindikata i kolektivnim ugovorima inertni, nespremni na promjene te da s vremenom postaju sve teže zapošljivi na tržištu rada jer njihove vještine postaju zastarjele zato što ne prate promjene koje bi im omogućile nova zapošljavanja. 
Fleksibilizacija tržišta rada koja dovodi do uklanjanja uspostavljenih institucija na tržištu rada koje štite radnike predstavljena je kao neminovna i nužna, a jedini način na koji pojedini radnici mogu sebi osigurati zaštitu na tom tržištu jest ulaganje u vlastiti ljudski kapital. Također, ova argumentacija podrazumijeva da radnici trebaju imati mogućnost da samostalno, to jest individualno pregovaraju o plaći i drugim pravima, kao na primjer o radnom vremenu, a sve u skladu s mogućnostima koje im pružaju individualne sposobnosti nastale ulaganjem u vlastito obrazovanje iz kojeg proizlazi njihova ,konkurentnost na tržištu rada”. U okviru ove argumentacije, iz jednadžbe radnih odnosa nastoji se izbaciti organizirani rad kao oblik zaštite prava radnika, a time i kolektivno pregovaranje. Zaštita radnika na razina kolektivnih ugovora i radnog zakonodavstva smatra se zastarjelim i ograničavajućim načinom zaštite i oblikovanja radnih prava jer onemogućuje individualno odlučivanje o radnom vremenu, vrsti posla, prekvalifikacijama i slično. Fleksibilnost tržišta rada koje proizvodi tržišno uređenje radnih odnosa $\mathrm{i}$ to na individualnoj razini smatra se pozitivnom i neminovnom politikom na suvremenom tržištu rada jer ona omogućuje veću slobodu izbora pojedincima što se tiče oblika rada i načina rada koje bi oni trebali moći prihvatiti ili izabrati te prema tim izborima raditi na vlastitu usavršavanju. Sigurnost radnika ne može se jamčiti zakonskim zaštitama, već je stručnost i kompetencija radnika najvažniji, ako ne i jedini izvor sigurnosti, pa se tako od radnika očekuje ulaganje u vlastito obrazovanje i usavršavanje kako bi se pripremili na izazove koje pred radnike postavlja suvremena tržišna ekonomska realnost.

Ministar rada tvrdi da se predloženim izmjenama jačaju fleksibilnost, prilagodljivost i mobilnost radnika, a poslodavcima se istovremeno omogućava brža prilagodba uvjetima na tržištu.

(G. Galović, Jutarnji list, 10.10.2013.)

Poslodavci smatraju da bi radnim zakonodavstvom trebalo urediti odnose između poslodavaca i radnika pod pretpostavkom da poslodavac nema namjeru izrabljivati radnika niti radnik ima namjeru iskorištavati poslodavca.

Treba im dati mogućnost da se dogovore u kakvom odnosu žele biti $i$ ponuditi im što više mogućnosti. Od rada na neodređeno vrijeme, preko onog na nepuno radno vrijeme, pa privremeno zapošljavanje ili povremeni rad. Sklapanje i razvrgavanje ugovora mora biti jednostavno. Na taj način najbolji će radnici 
najlakše prokrčiti put do najboljih poslodavaca, a kad dobri poslodavci nađu dobre radnike, teško će ih pustiti da odu.

(Dragana Radusinović, Jutarnji list, 25.8.2013.)

U okviru argumentacije o individualnoj odgovornosti pretpostavlja se da regulacija tržišta rada, odnosno postojeći Zakon o radu i sindikati ograničavaju slobodu pojedinca da se razvija, da radi na sebi i svojim vještinama i kompetencijama te da samostalno odlučuje u kojim uvjetima, koliko i kada želi raditi. Tako su prisutne tvrdnje da Zakon o radu treba mijenjati na način da se određeni uvjeti rada kod sklapanja ugovora o radu prepuste odlukama pojedinačnog radnika i poslodavca. Tako se odgovornost za zapošljavanje i plaću, pa i za nezaposlenost i siromaštvo, može potencijalno prebacivati na same radnike, iako, kako je već spomenuto u ranijim kritikama neoliberalnih pogleda, pitanje nezaposlenosti, ili kako ćemo vidjeti i u sljedećem primjeru, pitanje nemogućnosti otplaćivanja kredita nisu isključivo individualna odgovornost. Nezaposlenost i uvjeti kreditiranja problemi su koji nadilaze individualnu odgovornost; oni su sistemske prirode i valja ih rješavati na razini čitavog ekonomskog sustava i načina na koji je on postavljen. Tako u uzorku nalazimo i primjer osobe, pojedinca, koji želi dodatno zaraditi ne bi li lakše otplaćivao kredit u švicarskim francima. Međutim, radno zakonodavstvo postavlja ograničenje na maksimalno radno vrijeme čime onemogućuje radnike da bez ograničenja prakticiraju slobodu individualnih pregovora s poslodavcem.

„Imam stalni posao s ugovorom na 40 sati tjedno is obzirom na to da sam zbog kredita u švicarcima ušao u financijske probleme, potražio sam dodatni posao i uspio dogovoriti rad preko vikenda u jednom ugostiteljskom objektu. Dakle, u svoje slobodno vrijeme. No ni vlasnik tog objekta ni ja ne želimo da to bude na crno, već da sve bude u skladu sa zakonom. Želimo dakle platiti poreze, doprinose. No tu dolazimo pred zid“, govori Osječanin. Kod nadležnih institucija raspitao se kako da dodatni posao realizira legalno.

„Shvatili smo da je to nemoguće kad nam je prijatelj, inače inspektor rada, rekao da bi nam on u kontroli napisao kaznu jer bi takav rad bio protuzakonit. Strašno je da u ovoj državi ne možeš pošteno raditi i dodatno zaraditi. “

(Nikola Patković, Jutarnji list, 26.2.2013.) 
Slično sputavanje želje radnika za duljim radnim vremenom iz razloga što nema mogućnosti ni na koji drugi način zaraditi dovoljno veliku plaću kako bi se mogao uzdržavati, tiču se sezonskog rada i fleksibilnosti radnog vremena u sektoru turizma. Tako predstavnici poduzetnika u turizmu, prije prvih izmjena Zakona o radu, ističu interes radnika za što većom zaradom tijekom turističke sezone:

Pred potencijalnim investitorom $u$ hrvatski turizam stoji problem organizacije radnika u sezoni, jer aktualni Zakon o radu određuje takav raspored radnih sati da, pojednostavljeno rečeno, konobari koji gostima posluže večeru, iako po noći zapravo ne rade, ne smiju po zakonu raditi $i$ smjenu za doručak, pa turističke kompanije troše jako puno energije i novca kako bi efikasno organizirale uslugu za goste.

Rigidno radno zakonodavstvo zapravo onemogućuje sezonskim radnicima da u nekoliko mjeseci sezone rade koliko žele i zarade koliko mogu kad već zbog loše gospodarske situacije objektivno ne mogu naći stalni posao tijekom cijele godine.

(Dragana Radusinović, Jutarnji list, 5.5.2013.)

U uvjetima fleksibilnosti tržišta rada, stvaraju se veće mogućnosti za takozvani obrtaj radnika. Tako se, ironično, kao zaštita radnika promiče mogućnosti lakšeg mijenjanja posla, ali i to tek ako je u mogućnosti ulagati u vlastite vještine i znanja koji u kontekstu deregulacije znače i određene novčane izdatke, koji nisu nužno osigurani od poslodavca pa tako svi radnici zapravo nisu u mogućnosti ulagati u usavršavanje sposobnosti i vještina. Iz tog razloga svi radnici ni nemaju jednake šanse na tržištu rada, a zbog nejednakih materijalnih mogućnosti niti pristup potrebnom obrazovanju. Individualni odabiri radnika koji se odnose na znanja i vještine u koje smatra da treba ulagati svoje vrijeme i materijalne resurse također predstavljaju rizik koji se svodi na sposobnost radnika da razborito odabere ulagati u vještine i znanja na čiju korisnost i ,konkurentnost" može dugoročno računati. 


\subsubsection{Eufemizirani neoliberalni diskurs}

Eufemizirani neoliberalni diskurs u literaturi se poistovjećuje s diskursom Trećeg puta ili diskursom socijalnog tržišta, a sadrži kombinaciju argumenata o tržištu rada koji naoko nisu ideološki neoliberalno motivirani, ali najčešće sadrže latentnu dimenziju predanosti neoliberalnim imperativima kao što je konkurentnost i ponekad neumjesna dominacija mehanizama slobodnog tržišta (Phelan 2007b). Tako se postavlja pitanje može li se diskurs ekonomskih politika socijalno-demokratske provenijencije, kao što je Treći put, smatrati eufemiziranim diskursom ili ga je moguće promatrati kao interdiskurzivno polje u kojem se sastaju neoliberalni diskurs i diskurs socijalne države; kao spajanje dviju paradigmi iz praktičnih razloga. Auer (2007), a u nekom smislu i Bagić (2010), ističu da se iz perspektive radikalno lijevo orijentiranih kritičara neoliberalizma, diskurs Trećeg puta (koji je možda najsrodniji diskursu ordoliberalne varijante neoliberalizma) predstavlja kao ublažena varijanta transparentnog neoliberalnog diskursa konkurentnosti postignuta uključivanjem elemenata diskursa socijalne države. U tom je slučaju prisutna dilema oko toga može li se diskurs Trećeg puta, odnosno diskurs njemačkog ordoliberalizma koji za praktične svrhe uključuje i neke socijalne elemente, okarakterizirati kao neka vrsta „razblaženog“ neoliberalizma, eufemiziranog neoliberalizma, javnosti prihvatljivije retorike, ili bi to mogao biti jedini mogući diskurs socijalne države kao odraz nekakve vrste kompromisa, konsenzusa na tržištu rada, koji u sebi sadrži prihvaćanje okvira neoliberalnih politika u kojima se ostavlja prostor za solidarnost i socijalnu integraciju koje slobodno tržište samo po sebi ne može osigurati. Lijevi kritičari bi rekli da je to instrumentalizacija diskurzivnih elemenata socijalne države koju neoliberali koriste kako bi lakše ostvarili agendu svojih javnih politika s nadsvođujućim i neupitnim imperativima konkurentnosti, slobodnog tržišta i ekonomske učinkovitosti. U tom kontekstu Phelan (2007b) opisuje primjer eufemiziranog neoliberalnog diskursa za koji je karakteristično ugrađivanje kritike neoliberalnih politika kao i neoliberalizmu suprotstavljenih elemenata diskursa socijalne države, s time da su ti elementi u konačnici podređeni neoliberalnim imperativima.

U kontekstu analize diskursa o fleksibilizaciji tržišta rada, eufemizirani neoliberalni diskurs sadrži i argumentaciju modernizacije, koju nalazimo u analiziranim tekstovima kao neku vrste pretpostavke da se ono što je moderno i napredno na tržištu rada može izjednačiti s deregulacijom i fleksibilizacijom tržišta rada. Zagovornici fleksibilizacije tvrde da je Zakon o radu koji je donesen 2003. godine, za sadašnje vrijeme zastario, da predstavlja „prerigidan” okvir za suvremene radne odnose čime se onemogućuje ostvarivanje suvremenih proizvodnih 
odnosa. U sklopu ove argumentacije prisutna je i tvrdnja da je taj Zakon o radu toliko udaljen od prakse da se u mnogim poduzećima niti ne provodi, nego ga poduzetnici na razne načine zaobilaze. Argumentacijom modernizacije sugerira se da je postojeći Zakon o radu, odnosno onaj koji je bio važeći do 2014. godine, zbog navedene visoke razine radne zaštite prema očitanom visokom OECD-ovom EPL indeksu, zapravo prilagođeniji masovnoj fordističkoj proizvodnji, odnosno okolnostima koje su vladale neko vrijeme u prošlom stoljeću. Dio argumentacije o potrebi modernizacije Zakona o radu, odnosno odnosa na tržištu rada čine i tvrdnje kako se Zakon o radu takav kakav jest, zbog svoje navodne rigidnosti i za poslodavce ograničavajućih odredbi, u praksi rijetko i provodi. U kontekstu te tvrdnje se ukazuje na potrebu mijenjanja Zakona o radu ne bi li on bio ,životniji” i u skladu s uspostavljenim praksama, osobito u privatnom sektoru gdje se Zakon o radu, kako navode neki akteri, zbog svoje rigidnosti, često niti ne poštuje.

Argumentacija modernizacije može biti dio i neoliberalnog diskursa i diskursa socijalne države jer zaštita i prava radnika nisu nužno u suprotnosti s promjenama koje omogućavaju prilagodbu novim uvjetima proizvodnje nastalima zbog tehnoloških i društvenih promjena, kao što je na primjer rad na pola radnog vremena, ili rad sa skraćenim radnim vremenom i slično. Ukoliko se argumentacija modernizacije može povezati s rekombinacijom zaštita na tržištu rada koje u novim uvjetima mogu omogućiti izbalansiranost interesa radnika i poslodavaca, $\mathrm{u}$ tom slučaju argument modernizacije ne mora biti povezan s neoliberalnim diskursom. Promjene Zakona o radu predstavljene su kao neizbježni prijelaz iz starog u novo, pa se u tom kontekstu govori o „modernizaciji” Zakona o radu, o „liberalizaciji” Zakona o radu, pri čemu je naglasak na tome da je ono što se predlaže dobro jer se povezuje s procesom prijelaza iz zastarjelog $u$ nešto što je suvremeno i u skladu s rješenjima koja su prisutna u regulaciji rada u Europskoj uniji i drugim razvijenim zapadnim zemljama. Promjena Zakona o radu, koja se prikazuje kao nešto pozitivno jer označava tranziciju iz zastarjelog sustava, koji obilježava nerazvijenost, $u$ novi sustav koji pak predstavlja napredak i sustizanje razvijenijih zemalja, sukus je argumentacije modernizacije. Njome se u javnom diskursu legitimira donošenje izmjena Zakona o radu pri čemu se najčešće podrazumijeva, ponekad na transparentan, a ponekad na eufemiziran način, da predložene promjene predstavljaju „uvođenje tržišnih odnosa” na tržište rada u obliku fleksibilizacije deregulacijom. Dio argumentacije modernizacije čine i tvrdnje kako se određeni dijelovi Zakona o radu trebaju izmijeniti ne bi li organizacija rada mogla odgovoriti na zahtjeve novih, postindustrijskih uvjeta prisutnih u suvremenoj organizaciji proizvodnje i pružanja usluga. 
U ovu argumentaciju također možemo uvrstiti i tvrdnje da se osuvremenjivanjem Zakona o radu u Hrvatskoj priznaje realnost smanjivanja broja radnih mjesta u industrijskom sektoru s kojim se povezuje postojeći Zakonom o radu, koji iz tog razloga zahtijeva promjene naprosto zbog toga što suvremeni režim akumulacije kapitala to zahtijeva. U sljedećim primjerima pravni stručnjak i tadašnji član nadzornog odbora agencije za privremeno zapošljavanje Dekra, Viktor Gotovac te ekonomist Ante Babić na sličan način argumentiraju potrebu za deregulaciju tržišta rada i fleksibilizacijom:

Moramo shvatiti da danas više nema radnih odnosa kakvi su nekad postojali. Treba shvatiti da nećemo imati posao za cijeli život $i$ da ćemo morati raditi dva i više poslova da bismo imali puno radno vrijeme. Kada se 2003. u Hrvatskoj uvodio rad putem agencija za privremeno zapošljavanje, sindikati su bili protiv toga. Ali, protupitanje glasi: je li bolje da osoba bude nezaposlena ili da radi preko takve agencije? Sve je bolje od nezaposlenosti.

(Viktor Gotovac, prema: A. Milovan, Jutarnji list, 13.6.2013.)

Naš je strah od promjena toliki da promjene vidimo i tamo gdje ih nema, opiremo im se čak i kada su neizbježne jer ovo više nije svijet parnog stroja, fordizma, velikih serijskih nesofisticiranih proizvodnji i manualnog rada, izvoza $u$ nesvrstane, bogatih gastarbajtera, čije nam doznake dođu kao poklon dragog ujaka iz Wiesbadena ili glavni zgoditak na kladionici. Bitno je drugačiji svijet $u$ kojem živimo i radimo: u nas je 350.000 ili 360.000 nezaposlenih, imamo najnižu stopu zaposlenosti od svih država članica Europske unije, malo je naše proizvodnje koja je globalno poznata i priznata (razmislite koji je to naš proizvod poznat u svijetu?), naš rad je nekonkurentan, kao što je počesto zastarjela $i$ tehnologija naših postrojenja.

(Viktor Gotovac, Jutarnji list, 4.12.2013.)

„I u budućnosti će se sve više ljudi zapošljavati na određeno vrijeme i na nepuno radno vrijeme. To je posljedica tehnološkog napretka, Internet je jako promijenio i tržište rada $i$ donio fleksibilizaciju, htjeli mi to ili ne. Više nema 
zaposlenja za cijeli život. Ni sami radnici više ne žele cijeli radni vijek provesti kod istog poslodavca.

(Ante Babić, prema: A. Milovan, Jutarnji list, 1.7.2014)

U prikazanim primjerima vidimo spomenutu argumentaciju koja ističe da je fleksibilnost tržišta rada nešto što je u suvremenom svijetu, zbog promjena koje su se dogodile kako u industrijskoj proizvodnji tako i u tehnologijama, neizbježno i nema alternativu. U tom je kontekstu karakterističan i poznati neoliberalni stav kojeg je također zauzela britanska premijerka Margaret Thatcher, da mjere neoliberalnih politika nemaju alternativu. U svim je prethodnim primjerima modalnošću istaknuta nužnost promjena u smjeru fleksibilizacije formulacijama „moramo shvatiti”, „treba shvatiti (...) da ćemo morati raditi dva ili više poslova”, promjene su „neizbježne”, internet je donio fleksibilizaciju „htjeli mi to ili ne”. U posljednjem Gotovčevu primjeru vidimo usporedbu hrvatskog tržišta rada s jednako tako zastarjelom tehnologijom postrojenja pri čemu se implicira da je radno zakonodavstvo koje se u neoliberalnom diskursu smatra rigidnim, i koje stvara troškove poslodavcu štiteći radnike, zapravo relikt nekog prošlog doba koje se povezuje s razdobljem kada je Hrvatska bila dio Jugoslavije te da sadašnji Zakon o radu (iako je izmijenjen 2003. godine) kao da pripada socijalističkom razdoblju i to zato što standardni ugovor na neodređeno vrijeme definira kao glavni oblik zapošljavanja za većinu radnika i zato što u Zakonu postoje barijere koje sprječavaju suviše jednostavno otkazivanje ugovora o radu.

Argumentacija modernizacije u nekim dijelovima nije nekompatibilna s diskursom socijalne države, jer nije sporno da određeni aspekti radnih odnosa kakvi su postojali nakon drugog svjetskog rada, kao što kaže Viktor Gotovac, „u doba fordizma velikih serijskih nesofisticiranih proizvodnji i manualnog rada", nisu s jednakim udjelom radnih mjesta prisutni u suvremenom svijetu, da se zbog tehnologija mijenjaju radna mjesta i vještine koje su potrebne da bi se ta radna mjesta primjereno popunjavala. Međutim, ova tvrdnja ne znači da je tržište rada nužno deregulirati, već je moguće izmijeniti oblike regulacije kako bi se tržište rada prilagodilo novim načinima proizvodnje u određenim sektorima ovisno o stanju u gospodarstvu i strukturi radne snage na tržištu rada. Esping-Andersen i Regini (2000) također upozoravaju da u vremenima kada se sve više radnika zapošljava u sektoru usluga, potrebe poslodavaca i potrebe posla razlikuju se od rada u nekadašnjim tvornicama kada se proizvodnja, a time i potreba za radnom snagom, mogla koliko toliko dugoročnije planirati. 
„Na tipičnoj se konferenciji visoke razine o nezaposlenosti u Europi obično dolazi do sljedećeg zaključka: „ono što tražimo je odgovarajuća ravnoteža između socijalnih jamstava i fleksibilnosti”. Nije iznenađuje da se svi mogu s time složiti. Nitko naravno nije ni približno kadar odrediti tu ravnotežu. Još gore, to je nemarno razmišljanje; pogrešan način pristupanja tom pitanju. Pitanje nije koliko daleko možemo gurati polugu deregulacije, a da ne naštetimo društvenom tkivu, već kako rekombinirati postojeće regulacijske elemente tako da nam pomognu ostvariti ono što želimo“ (Esping-Andersen i Regini 2000: 4).

Esping-Andersen (2000) također ukazuje na to da se porast ponude poslova većinom zasniva na proširenju sektora usluga u kojem učinci i potrebe za fleksibilnošću nisu do kraja razjašnjeni. Argument koji se u kontekstu modernizacije Zakona o radu nudi kao afirmirajući za deregulaciju jest prilagođavanje suvremenoj proizvodnji. Jedan od razloga zašto u mnogim zemljama dolazi do povećanja stopa nezaposlenosti jesu procesi deruralizacije i deindustrijalizacije te se u budućnosti, prema Esping-Andersenu i Reginiju (2000) ne očekuje povećanje broja radnih mjesta u industrijama, već u tercijarnom sektoru, odnosno u uslužnoj djelatnosti.

To znači da bi Zoran Milanović morao javno predstaviti sve ključne ekonomsko-strukturne korake za 2014. godinu, da bi morao politički kontekstualizirati dva glavna ekonomska zakona svoje administracije; Zakon o radu, i Zakon o strateškim investicijama, i da bi trebao iznijeti procjene efekata tih glavnih zakona, kao i drugih ekonomskih i socijalnih mjera, na stanje hrvatske ekonomije i na standard građana u iduće dvije godine. (...)

Milanović će međutim, moći pobijediti jedino ako sve one razočarane građane, koji u svakoj novoj godini vide sve lošiji život $i$ sve gore poslovne uvjete, uvjeri kako je dovoljno odlučan da počne pretvarati Hrvatsku iz konsenzualnog socijalnog društva, koje propada, u moderno tržišno-socijalno društvo, u kojem se ponovno može uspješno poslovati i dobro živjeti.

(Davor Butković, Jutarnji list, 14.12.2013.)

U argumentaciju modernizacije također možemo uvrstiti i argumente koji promiču deregulaciju radnih odnosa jer ona u suvremenim okolnostima nije primjenjiva. Ta tvrdnja da 
je Zakon o radu toliko rigidan da je zapravo neprimjenjiv, redovito se pojavljuje u javnom diskursu kroz tvrdnje da se pojedini akteri, osobito privatni poduzetnici, ne pridržavaju Zakona o radu i ne pružaju radnicima zakonom zajamčene zaštite jer za to nemaju uvjete ili im je to preskupo. Razlozi zbog kojih se u kontekstu modernizacije spominje argument neprovođenja Zakona o radu oslanjaju se na hipoteze da je zakonom zajamčena razina zaštite i prava radnika previsoka pa time za pojedine poduzetnike i preskupa, ili pak iz razloga što se zbog promjena u modernim procesima proizvodnje, pružanja usluga i slično, nije moguće pridržavati nekih odredbi. Poduzetnici tako na neformalan način i u dogovoru s radnikom mogu pronaći načine ušteda unatoč visokom stupnju prava radnika i radnih zaštita. Ovaj argument zaobilaženja radnih zaštita spomenuli su i Deakin i Wilkinson (1994) kojeg pripisuju neoliberalnim, odnosno neoklasičnim ekonomskim perspektivama na radne zaštite. Autori naime tvrde da taj argument zapravo govori u prilog regulaciji tržišta rada. Jer ukoliko je radne zaštite moguće na razne načine zaobilaziti u dogovoru s radnikom, onda one nemaju nikakve negativne ekonomske učinke, dok mnogi aspekti regulacije kao što je na primjer zaštita od diskriminacije, imaju pozitivan učinak na povećanje socijalne zaštite.

Zadnje značajnije izmjene Zakona o radu bile su 2003. godine. Nakon toga sve izmjene imale su za cilj usklađivanje s direktivama Europske unije. A niti to nismo napravili kako bi trebalo već smo samo postojeći zakon nadograđivali s odredbama direktiva u najstriktnijem mogućem smislu. I dobili smo toliko kompliciran zakon da ga rijetki razumiju, a oni koji ga razumiju ne mogu ga primjenjivati jer je neživotan, neki poslodavci će reći neodrživ, odnosno teško primjenjiv. Za to vrijeme najrazvijenije države Europske unije koje su već tada bile daleko ispred nas po razvijenosti radnih odnosa, tražile su i dalje kako da razvijaju radno zakonodavstvo u smjeru zapošljavanja, rasta i konkurentnosti.

(Nataša Novaković, Večernji list, 17. 10. 2013.)

U kontekstu argumentacije o fleksibilizaciji tržišta rada kao dijelu procesa modernizacije koji u Hrvatskoj nije doveden do odgovarajućih razina, u javnom diskursu prisutne su usporedbe Hrvatske i drugih zemalja Europske unije. Kada je riječ o fleksibilnosti tržišta rada ono hrvatsko uspoređuje se s regulacijom tržišta rada u drugim zemljama Europske unije za koje se podrazumijeva da su naprednije, između ostalog i zbog toga što su poodmakle 
u procesima fleksibilnosti rada, odnosno imaju drugačije uređeno, fleksibilnije radno zakonodavstvo. Prema nekim je akterima važno, pa čak i neizbježno, prilagoditi postojeći Zakon o radu praksi, mada u slučaju prilagodbe Zakona o radu modernom načinu proizvodnje, ili možda u suvremeno doba sve raširenijem sektoru usluga, uvijek postoji mogućnost novih oblika regulacije i uspostavljanja drugih zaštita radnika i radničkih prava koji onda zapravo zahtijevaju neku vrstu kombinacije deregulacije s novim, prilagođenijim oblicima regulacije tržišta rada (Esping-Andersen 2000, Stanford i Vosko 2004). Naravno da je moguće prilagoditi postojeću regulaciju, ako se za to pokazuje potreba, novim oblicima organizacije rada na način da se radnicima kada gube zaštitu ili pravo u jednom aspektu radnog ugovora taj gubitak kompenzira kroz neki drugi oblik zaštite ili prava. Dakle, nije fleksibilizacija s ciljem prilagodbe modernom rasporedu poslova prema sektorima i zahtjevima suvremenog razvoja tehnologije sama po sebi sporna, već način na koji se ta deregulacija provodi i je li ona u konačnici u ime modernizacije predstavlja sveukupni gubitak na strani radnika.

U kontekstu argumenta modernizacije također je značajno istaknuti i antagonistički stav pojedinih aktera prema sindikatima koje se prokazuje kao iracionalne jer se ,protive svakoj promjeni", zajedno s tvrdnjama da su navedene promjene neizbježne jer predstavljaju neminovno uvođenje tržišnih odnosa u svijet rada. Na taj se način i sindikati, odnosno sindikalno organiziranje nastoji prikazati kao nešto što pripada prošlim vremenima, dok su za sadašnje vrijeme prikladniji individualni ugovori između radnika i poslodavca.

Budu li se na svaku liberalizaciju naslanjala nova ograničenja, možda je ipak bolje ništa ne mijenjati! To je zaključak koji su u Hrvatskoj udruzi poslodavaca iznijeli nakon lobiranja za liberalizaciju radnog zakonodavstva. Sindikati će se objeručke uhvatiti za tu rečenicu u želji da postignu upravo to - zaustavljanje svake promjene! Smatraju ih nepotrebnima.

(Dragana Radusinović, Jutarnji list, 25.8.2013.)

Istaknuti dio javnog diskursa o fleksibilizaciji tržišta rada čini i pitanje utjecaja regulacije, odnosno fleksibilnosti tržišta rada na nezaposlenost, zapošljavanje i otvaranje novih radnih mjesta. Argumentacija rješavanja problema nezaposlenosti također nije u suprotnosti s diskursom socijalne države, odnosno ovisno o naglascima može pripadati i neoliberalnom diskursu, ali i oponirajućim diskursima. Neki aspekti predložene fleksibilizacije nisu u skladu 
s ciljem smanjivanja nezaposlenosti, kao što je na primjer skraćivanje vremena za odmor, smanjivanje ograničenja tjednog radnog vremena ili na primjer olakšavanje otpuštanja radnika, pogotovo u kontekstu olakšavanja procesa takozvanog restrukturiranja. Međutim, kao što naglašavaju i Esping Andersen i Regini (2000), postoje naznake da neki aspekti regulacije utječu na koncentraciju nezaposlenosti u određenim skupinama radnika, a to su na europskim tržištima rada osobito mladi, žene te niskokvalificirani radnici. Zato bi neke specifične politike na tržištu rada, koje bi išle u smjeru fleksibilizacije odnosno deregulacije, mogle biti opravdane u okviru diskursa socijalne države jer dovode do demokratizacije nezaposlenosti ukoliko se kreću u smjeru stvaranja prostora za zapošljavanje navedenih, teže zapošljivih skupina radnika. Međutim, prema Esping-Andersenu (2000) to onda podrazumijeva samo djelomičnu i ciljanu deregulaciju tržišta rada, obično popraćenu nadopunjujućim oblicima zaštite radnika. On također smatra da deregulacija u smjeru fleksibilizacije sama po sebi neće dovesti do smanjivanja stope nezaposlenosti, već samo do njezine preraspodjele. Na smanjivanje stope nezaposlenosti najviše utječu makroekonomske politike, odnosno monetarna i fiskalna politika kao i nove mogućnosti otvaranja radnih mjesta u sektoru usluga te državno subvencioniranje radnih mjesta.

Argumentacija rješavanja problema nezaposlenosti u određenoj se mjeri nadovezuje na prije spomenute argumentacije, osobito na argumentaciju konkurentnosti kao preduvjeta za privlačenje investicija. Međutim, temeljna, ali često neizrečena podloga za argumentaciju rješavanja problema nezaposlenosti već je spomenuto neoliberalno shvaćanje tržišta rada prema kojem do potražnje za radom na tržištu dolazi kada se uklanjanjem institucija tržišta rada i intervencionističkog zakonodavstva omogući tržišno prilagođavanje cijene rada na neku, dovoljno nisku razinu. Zagovornici fleksibilizacije deregulacijom tržišta rada najvećim dijelom ublažavaju formulaciju kojom bi isticali snižavanje cijene rada za veću stopu zaposlenosti, ali najčešće ističu kako će se smanjivanjem cijene rada stvoriti pozitivna poduzetnička klima koja će omogućiti stvaranje radnih mjesta. Također se ističe kako bi se uvođenjem atipičnih oblika zapošljavanja, kao što je rad preko agencija za privremeno zapošljavanje ili rad na nekoliko dana ili nekoliko mjeseci, rad sa skraćenim radnim vremenom, omogućilo otvaranje novih radnih mjesta. Ukoliko je u javnom diskursu naglasak na smanjivanju cijene radne snage, pri čemu će potražnja porasti i tako smanjiti agregatnu nezaposlenost, onda ta argumentacija o nezaposlenosti pripada neoliberalnom diskursu. Unatoč tome što neoliberalno usmjereni zagovaratelji fleksibilizacije tržišta rada u zamjenu za snižavanje cijene rada obećavaju otvaranje radnih mjesta, prema kritičarima fleksibilizacije, ukoliko snižavanje cijene rade ne bi 
bilo popraćeno i odgovarajućim makroekonomskim politikama koje potiču potrošnju, do smanjivanja nezaposlenosti uopće ne mora doći. Tada se fleksibilizacijom samo smanjuje kvaliteta radnih mjesta, naknade za rad i zaštita samih radnika. Međutim, ukoliko se ističu atipični oblici rada kao sredstvo ulaska na tržište rada i stepenica na putu do standardnog ugovora o radu na neodređeno vrijeme, osobito u funkciji zaštite (visokoobrazovanih) mladih te drugih teže zapošljivih skupina nezaposlenih, i to u kombinaciji s politikom potrošnje, a ne politikom štednje, onda je moguće govoriti i o socijalno pozitivnim aspektima deregulacije. Podijeljenost oko mogućih učinaka atipičnih oblika rada kao prakse snižavanja cijene rada prikazana je u sljedećem primjeru gdje se ističe privremeno zapošljavanje kao odgovor na krizu na tržištu rada, nasuprot tvrdnjama koje ukazuju na dugoročne nedostatke politike deregulacije koja smanjuje radne zaštite. Zagovaratelji fleksibilizacije često u javnom diskursu ističu da postoji izbor između atipičnih oblika rada i nezaposlenosti, pri čemu se iskazuje stav da je fleksibilizacija tržišta rada zapravo jedini način na koji je moguće stvarati radna mjesta. Dakle neoliberalni diskurs fleksibilizacije nameće logiku izbora ili fleksibilnost ili nezaposlenost; ili mogućnost korekcije cijene rada na tržištu ili visoka razina nezaposlenosti jer nema mogućnosti stvaranja novih radnih mjesta.

Novi Zakon o radu, posebice odredba kojom se produljuje mogućnost zapošljavanja putem agencija za privremeno zapošljavanje s jedne na tri godine, podijelio je hrvatsku javnost. I dok vojsci s više od 380 tisuća nezaposlenih ne bi nimalo smetalo da dođu do plaće makar i kao zaposlenici jedne takve agencije, sindikati, ali i neki političari, uvjereni su da će takav način zapošljavanja s vremenom iskorijeniti zapošljavanje na neodređeno vrijeme te da će radnici biti još slabije plaćeni i još manje zaštićeni.

(P. Maretić Žonja, Večernji list, 28.2.2014.)

Ekonomski stručnjak Josip Tica, kada govori o nezadovoljavajućim stopama zaposlenosti i nezaposlenosti, opisuje sljedeće:

(...) “Drugi razlog je stupanj rigidnosti radničkog zakonodavstva $i$ visina radničkih prava u smislu naknada za nezaposlene, otkaznih rokova, skupoće otpuštanja i slično. Naravno, treba biti svjestan kako kod nas u praksi često ta 
prava i ne postoje jer se zakon ne poštuje, ali na papiru postoje i u javnom sektoru $i$ u velikim privatnim sustavima se primjenjuju $i$ stvaraju posljedice na funkcioniranje cijeloga sustava“, upozorava prof. Tica.

Kao moguće rješenje ističe primjer deregulacije tržišta taksi usluga u Zagrebu i to je obrazac koji bi trebalo slijediti s cijelim nizom drugih sektora $u$ kojima vladaju monopoli. Ključni korak je fleksibilizacija tržišta rada i smanjenje relativnog udjela javnog sektora. „,Nažalost, do sada su svi bježali do ovih politika jer su otpori onih čija se prava režu ogromni, a dobici su u budućnosti disperzirani na čitavu populaciju i nezaposlene ljude koji tek trebaju dobiti posao nakon što se mjere provedu“", upozorava Tica.

(Josip Tica, prema: G. Galović, Turčin, Jutarnji list, 13.12.2013.)

U prethodnom je primjeru vidljiva povezanost između argumentacije o smanjivanju nezaposlenosti fleksibilizacijom tržišta rada i argumentacije restrukturiranja javnog sektora, odnosno smanjivanja broja zaposlenih koji su pod najvećom zaštitom sindikata. Ekonomski stručnjak Josip Tica navodi razloge niske stope zaposlenosti u koje ubraja i druge probleme u Hrvatskoj osim onih koji se odnose na takozvanu monopolizaciju tržišta rada pod utjecajem organiziranog rada $\mathrm{u}$ javnom sektoru. Tica navodi da je niska stopa zaposlenosti radno sposobnog stanovništva prisutna još od doba tranzicije i Domovinskog rata, dok se ta situacija dodatno pogoršala zbog gospodarske krize. Tica također navodi da postoji nekoliko razloga zbog kojih je stopa zaposlenosti niska kroz tako dugi vremenski period, dakle ukazuje na postojanje i drugih razloga koji utječu na situaciju niske zaposlenosti.

\subsubsection{Diskurs socijalnog partnerstva}

Diskurs socijalnog partnerstva također je problematično smještati u ladice „općenitijih“ diskursa kao što su neoliberalni ili diskurs Trećeg puta, ili pak nešto treće. Kao što je već ranije bilo navedeno, iz perspektive sindikata i zaštite radnika, postoje određene naznake da diskurs povezan s pojmovima partnerstva, u određenim slučajevima može predstavljati eufemizirani neoliberalni diskurs. Eufemizirani neoliberalni diskurs partnerstva ili socijalnog partnerstva ima za svoj cilj pacificirati konfliktna djelovanja organiziranog rada čime ga efektivno primorava na suradnju u ostvarenju ekonomističkih ciljeva imperativa konkurentnosti, pri čemu je značenje solidarnosti, povezano sa socijalnim dijalogom, socijalnim partnerstvom i konsenzusom, u diskursu zapravo subvertirano i izjednačeno s podupiranjem interesa kapitala, 
odnosno osiguravanja podrške poslodavcima za ostvarenje konkurentnosti na trošak rada (McIlroy 2009). Sindikati se u kontekstu ove argumentacije nastoje diskreditirati na temelju argumenta da ne zastupaju prava svih radnika te da im nije cilj ostvarenje zajedničkog interesa koji će pogodovati svim radnicima, već da se zalažu samo za svoje članove i to na štetu interesa ostatka društva.

U sljedećem je primjeru prikazano kako predstavnik poslodavaca Ivica Mudrinić govori o zajedničkom interesu i konsenzusu koji je potreban između svih industrijskih aktera, odnosno članova društva kako bi se ostvarili ciljevi za koje on smatra da su od nacionalnog interesa:

Zbog toga je važno da se donese jedna vrsta deklaracije koja će nas ujediniti. U Nacionalnom vijeću za konkurentnost nazvali smo je povelja kojom bi se opisalo željeno stanje u budućnosti, a iza koje bi svi ključni čimbenici u društvu stali: pozicija, opozicija, sindikati, poslodavci, akademija i lokalna vlast. Naravno da pritom mislimo na minimalni konsenzus. No, ipak, kada bismo se složili o nužnom razvojnom minimumu, fokus cijelog društva usmjerili bismo prema budućnosti. U Hrvatskoj je samo 23,7 posto visokoobrazovanih građana, cilj nam može biti da ih bude 40 posto te da udio radno angažiranog stanovništva dignemo iznad 66 posto, što je europski prosjek. Kad bismo imali zajedničke ciljeve, odjednom bi se u Hrvatskoj sve promijenilo jer bi konsenzus bio mehanizam za fokusiranje svih snaga prema budućnosti, a ujedno bi omogućio da svi stanemo iza reformi. Vidjeli smo u proteklim mjesecima koliko je lako da bilo koja ideja ili inicijativa nađe na neku kritičnu masu otpora i onda se za nju zalijepe ili oporba ili sindikati ili netko treći i zaustavi svaki proaktivan napredak.

(Ivica Mudrinić, prema: M. Šunjerga, Večernji list, 1.6.2013.)

U navedenom isječku iz intervjua danog za Večernji list možemo prepoznati karakteristike onoga što je Phelan (2007b) opisao kao eufemizirani neoliberalni diskurs. Interesi poslodavaca, odnosno kapitala nisu otvoreno iskazani kao dominantni interesi, iako postoje naznake zastupanja interesa kapitala s obzirom na to da se $\mathrm{u}$ argumentaciji razvija kritika sindikata zbog protivljenja nekim inicijativama, iako nije navedeno koje bi inicijative bile sporne. U planu Nacionalnog vijeća Ivica Mudrinić navodi plan da se poveća broj visokoobrazovanih ljudi, iako je neobično pretpostaviti da taj konsenzus u društvu već ne 
postoji, ili da je on predmetom neslaganja između industrijskih aktera, u javnosti ili među akademijom. Isti je slučaj i s povećanjem stope zaposlenosti, čijem se rastu nitko u javnosti ne protivi ili ga osporava. Dakle, nisu sporni ciljevi koji trebaju biti ostvareni u kontekstu hrvatske ekonomije, već su sporne metode za koje se tvrdi da bi trebale te ciljeve ostvariti i njihove dugoročne posljedice. Naglašava se pokušaj da se između svih dijelova društva koji imaju određeni utjecaj u javnosti, odnosno političara u opoziciji, sindikalista i akademika usuglasi provođenje politika čiji bi motiv bilo stvaranje konsenzusa o napretku Hrvatske kako ga vidi Nacionalno društvo za konkurentnost. U okviru diskursa o socijalnom partnerstvu i konsenzusu pojavljuje se i teza koja neizravno upućuje na to da demokracija koči ekonomski napredak pojedinih država jer su interesi stranaka na vlasti ovisni o očekivanju rezultata izbora, pa se političke odluke donošenja određenih politika koje se odnose na državni proračun, odnosno potrošnju mogu, prema procjenama neoliberalnih ekonomista negativno održavati na interese nacionalnih ekonomija (Blyth, 2013).

Diskurs socijalnog partnerstva povezan je s njemačkom strujom neoliberalizma, odnosno ordoliberalizmom, u kojem postoji naglasak na važnosti osiguravanja dovoljno visoke kvalitete života s dostojnom razinom prihoda za radnike, što je sadržano u sintagmi ,socijalnog tržišta". Phelan (2007a, 2007b) pri razlikovanju eufemiziranog i transparentnog neoliberalnog diskursa ukazuje na sličnosti ekonomske paradigme Trećeg puta i njemačke varijante neoliberalizma, s naglascima na zajedničkom interesu, izbjegavanju ideoloških odrednica naglašavanjem suradnje i neisplativosti, nepragmatičnosti, pa čak i nepostojanju temeljnih konflikata između rada i kapitala koje on smješta u mozaik medijske neoliberalne hegemonije.

Argumentacija nacionalnog interesa koristi se socijalnim partnerstvom kao praznim označiteljem preko kojega se određeni (partikularni) interesi prikazuju kao zajednički. Na taj se način imperativi konkurentnosti, odnosno tržišnog natjecanja, izjednačavaju s napretkom, dok se istovremeno gura u pozadinu zaštita radnog mjesta i prava radnika te obostrana solidarnost. Dakle, sindikatima preostaje jedino složiti se s predloženim reformama, ili ih odbiti, a s obzirom na to da je prihvaćanje određene (neoliberalne) politike postavljeno u taj odnos dijaloga i partnerstva, sindikate je u slučaju neslaganja s predloženim promjenama u zadanom okviru socijalnog partnerstva lako prikazati iracionalnima i nedobronamjernima jer odbijaju raditi za zajednički interes što je implicitno sadržano u sintagmi „socijalnog partnerstva". U sljedećem primjeru o pregovorima o Zakonu o radu, vidljivo je da je jedan neimenovani sindikalac svjestan pozicije u kojoj se nalaze sindikati s obzirom na to da se od 
sindikata očekuje da prihvate već predložena rješenja izmjena Zakona o radu i to pod pretpostavkom da su te izmjene zajednički nacionalni interes:

„Ne znam hoćemo li se dogovoriti. Sve je na stolu, a bojim se da su sindikati upali u klopku da pregovaraju o manje lošim rješenjima, a ne stvarnom kompromisu. Osobno nisam zadovoljan smjerom u kojem idemo”, otkriva jedan sindikalac.

U Hrvatskoj udruzi poslodavaca su optimistični.

„Pregovori se nastavljaju. Vremena imamo i slijedeći tjedan i uvjeren sam da idemo u dobrom smjeru i da je moguć dogovor jer je u interesu sviju da se Zakon o radu donese”, ističe Davor Majetić, glavni direktor HUP-a.

S obzirom da se sindikati i poslodavci ne mogu sami dogovoriti, ministar rada Mirando Mrsić proteklih je tjedana odvojeno razgovarao s jednom i drugom stranom.

Sada su svi zajedno za stolom.

O Zakonu o radu praktički bezuspješno pregovaraju posljednjih godinu dana.

„Mi smo trenutno na poziciji da smo zadovoljni i manjim pomacima koji će poslodavcima na bilo koji način olakšati poslovanje”, poručuje pak jedan od poslodavaca.

(Gordana Galović, Jutarnji list, 2.4.2014.)

U tom je smislu sindikatima otežano protiviti se reformama koje mogu biti oblikovane prema neoliberalnim zahtjevima jer ih se u javnosti može relativno jednostavno diskreditirati. Socijalno partnerstvo kao oblik praznog označitelja omogućuje prebacivanje odgovornosti s jednog aktera na drugog u slučajevima prekida socijalnog dijaloga, što predstavlja relativno čestu temu u okviru teme rasprava o Zakonu o radu u analiziranom razdoblju. Primjerice, u javnom diskursu je prisutno prebacivanje odgovornosti između Vlade, sindikata i poslodavaca za „raspad socijalnog dijaloga”. Eufemizirani neoliberalni diskurs sadrži već uvriježeni diskurs socijalnog partnerstva koji je identificiran kao diskurs s funkcijom pacificiranja organiziranog 
rada. Većina se kritika djelovanja sindikata zasniva na tvrdnji da sindikati zastupaju interese samo jednog dijela zaposlenih te da ne uzimaju u obzir zaposlenike iz privatnog sektora, a ponajviše se diskursom o narušavanju socijalnog dijaloga izražava antagonizam prema otporima sindikata. Zagovarajući fleksibilizaciju tržišta rada kroz promicanje diskursa socijalnog dijaloga i socijalnog partnerstva, u javnom se diskursu nastoji na razne načine diskreditirati ne samo sindikate i to što oni predstavljaju, već se dovodi u pitanje opravdanost i mogućnost otpora predloženim promjenama koje podrazumijevaju provođenje neoliberalnih politika fleksibilizacije tržišta rada.

U okviru argumentacije nacionalnog interesa ističe se da je fleksibilizacija tržišta rada, kao dio paketa politika koje se propisuju za izlazak Hrvatske iz krize, zapravo zajednički nacionalni interes hrvatskog društva. Tu se ističe da sindikati svojim otporom utječu negativno na čitavo društvo pri čemu onemogućavaju njegov napredak, dok se društvenim napretkom smatra ostvarivanje ekonomskih interesa poduzetnika kroz omogućavanje poslodavcima da budu konkurentni smanjivanjem troškova rada.

\section{U HUP-u su jučer ocijenili da generalni štrajk koji najavljuju sindikati} uopće ne postoji u trenutnim zakonskim okvirima pa je pitanje u kojem obliku on uopće može biti organiziran. „Na štrajk mogu pozivati samo oni koji nisu prijatelji ove države”, poručio je Branko Roglić.

(Roglić prema: G.G.,Jutarnji list, 22.1.2014.)

Primjer iskaza o iracionalnosti otpora promjenama u smjeru fleksibilizacije, odnosno ukazivanje na to da sindikati zbog nerazumijevanja ne podržavaju predloženu inačicu Zakona o radu koji je u interesu i poslodavaca i radnika, daje Ivica Mudrinić. U sljedećem primjeru vidimo ispreplitanje više vrsta argumentacija koje čine neoliberalni diskurs; pa tako imamo argument konkurentnosti, argument ljudskog kapitala ili individualne odgovornosti, i argument socijalnog partnerstva, preciznije, kombinaciju elemenata transparentnog i eufemiziranog neoliberalnog diskursa. Eufemiziranost diskursa sadržana je u tome što se $u$ ovom komunikacijskom događaju ne priznaje otvoreni antagonizam prema sindikatima, već se učvršćuje vizija zajedničkih interesa čitavog društva, uključujući i radnike i sindikate, pri čemu se kao društveni interes postavlja ekonomski interes, jer se kao odrednica napretka spominje „konkurentnost društva”, za razliku od društvene integracije ili društvene solidarnosti. 
Naglašavanjem konkurentnosti te paketa politika koji trebaju izvesti zemlju iz krize te toga da se odgovor na smanjenje radne sigurnosti, pa time i dimenzije socijalne zaštite nastoji kompenzirati uvođenjem još više tržišta kroz dodatnu liberalizaciju ostalih aspekata ekonomije, ukazuje na artikulaciju transparentnog neoliberalnog diskursa. Iz sljedećeg se odlomka prepoznaje kombinacija transparentnog i eufemiziranog neoliberalnog diskursa osobito $\mathrm{u}$ kontekstu odnosa prema sindikatima, pri čemu se ne iskazuje otvoreno neprijateljstvo već se naglašava žaljenje što sindikati protivljenjem Zakonu o radu odbijaju djelovanje s ciljem boljitka i napretka čitavog društva, pri čemu je napredak društva viđen primarno kroz prizmu konkurentnosti. U ovom je izvatku iz analiziranog teksta također istaknuto da je, suprotno od predodžbe sindikata koji predloženu fleksibilnost koja deregulacijom radnike izlaže tržištu na kojem su u slabijoj poziciju u odnosu na poslodavce, promatraju izvorom nesigurnosti te urušavanjem radničkih prava, fleksibilizacija zapravo izvor sigurnosti radnika. Neoliberalna je pretpostavka da će snage tržišta natjerati radnike da se u situaciji u kojoj ne uživaju velike radne zaštite potrude uložiti u svoj ljudski kapital ne bi li bili „,konkurentniji“ na tržištu rada. U tom se smislu potreba za konkurentnošću proširuje s države, na same kompanije, pa naposljetku sve do samih radnika koji svoje zaposlenje moraju shvaćati kao opstanak na tržištu rada te se kroz tu argumentaciju negira potreba za zakonskom zaštitom. Pretpostavka ulaganja u ljudski kapital i premisa o potrebi da radna snaga bude konkurentna, to jest da pojedini radnici budu konkurentni na tržištu rada, implicira da je tržište rada kao svako drugo slobodno tržište, ono na kojem sposobni opstaju, a nekonkurentni „otpadaju” u nezaposlenost jer su izgubili tržišnu utakmicu. To su implikacije neoliberalne teorije ljudskog kapitala čije praktično zagovaranje predstavlja odustajanje od kejnzijanskih nastojanja ostvarenja pune zaposlenosti i pretpostavlja postojanje prirodne stope nezaposlenosti što je u skladu s neoliberalnom ekonomskom paradigmom.

„Zakon o radu sam po sebi neće riješiti sve teške gospodarske probleme”, kazao je na Hrvatskom radiju u emisiji ,, Intervju tjedna” predsjednik HUP-a Ivica Mudrinić.

Izjavio je kako prijetnje sindikata općim štrajkom i izazivanjem 'grčkog scenarija' ne vidi kao neprijateljstvo prema državi, kako je nedavno ustvrdio jedan od čelnika HUP-a, nego kao nerazumijevanje sindikata za iznimno tešku gospodarsku situaciju u Hrvatskoj, kojoj je potreban paket mjera za obračun s dugotrajnom krizom. 
A jedan od alata za obračun s tom krizom, kako kaže Mudrinić, upravo je Zakon o radu.

„Nama treba Zakon o radu koji omogućuje sigurnost radniku napredovanje, obrazovanje i pripremu za iduće radno mjesto. Ako uvedemo rigidno zakonodavstvo, onda onemogućujemo radne procese i mi kao društvo postajemo nekonkurentni."

(Ivica Mudrinić, Jutarnji list, 26.1.2014.)

Diskurs socijalnog partnerstva u nekim se primjerima može okarakterizirati kao eufemizirani neoliberalni diskurs koji negira postojanje suprotstavljenih interesa između radnika i poslodavaca. U prethodnom primjeru se napretkom nastoji prikazati samo ono što je u ekonomskom smislu povoljno za poslodavce. Konsenzus između rada i kapitala ne uspostavlja se u uvjetima u kojima se jasno priznaje da ono što je dobro za poslodavce ne mora biti dobro i za radnike. S obzirom na nastojanje poslodavaca da povećaju profit te da to učine smanjivanjem troškova rada i smanjivanjem prava radnika jasno je da interesi poslodavaca često nisu kompatibilni $\mathrm{s}$ interesima zaposlenika. U okviru eufemiziranog neoliberalnog diskursa o fleksibilizaciji tržišta rada pretpostavka za konsenzus je pristajanje radnika, odnosno sindikata na to da je bilo kakav posao bolji od nezaposlenosti. Istovremeno se ne postavlja pitanje kako će takav posao čija je kontrola prepuštena poslodavcima između ostalog i zbog fleksibilizacije provođene deregulacijom prema zahtjevima poslodavaca, utjecati na zdravlje i dobrobit radnika. Jesu li to poslovi koji će im omogućiti materijalnu sigurnost, plaću dostatnu da mogu brinuti o obitelji, s radnim vremenom koje uvažava potrebe usklađivanja privatnog i profesionalnog života, ili su to poslovi koji će radnicima zagorčavati živote.

Argumentacija nacionalnog interesa proširuje se i na područja političkog diskursa nastojeći neutralizirati otpore koji dolaze i od stranaka koje su u opoziciji, a usmjereni su prema stranci na vlasti koja u najvećoj mjeri predlaže sadržaj i tijek reformi. Mark Blyth (2013) ukazuje na ovu pojavu kritike demokracije u kontekstu neoliberalnog diskursa koji demokraciju smatra političkim sustavom čiji mehanizmi pogoduju politikama potrošnje te na taj način stvaraju dug, odnosno deficit države. U tom kontekstu možemo promatrati i argumentaciju nacionalnog interesa koja se zalaže za suradnju svih dijelova društva u ostvarivanju ekonomskih politika koje se odnose prvenstveno na reforme s ciljem smanjivanja potrošnje države, odnosno politiku rezova ili politiku austeriteta. U kontekstu gospodarske krize i 
pritisaka na marginalizaciju demokratskih procesa u nastojanjima prevladavanja krize i uvođenja opće politike štednje, počela se pojavljivati argumentacija koja promiče takozvanu veliku koaliciju između desnih i lijevih, odnosno između dvije najveće stranke u državi, implicirajući da područje ekonomije nije nešto o čemu se može ili treba odlučivati na parlamentarnim izborima, već je to dan postupak provođenja preporučenih politika koje sve „odgovorne” vlade moraju provoditi bez obzirna na svoju političko-ideološku usmjerenost (Blyth 2013). Ta argumentacija upućuje na to da u ključnim politikama koje se odnose na onaj ekonomski dio, ne treba očekivati prijepore oko onoga što se smatra temeljnim ekonomskim pretpostavkama i uvriježenim gospodarskim praksama u koje na primjer spada i politika štednje. Naime, demokracija ima svoje nedostatke jer stvara dug iz razloga što političari na kraju mandata, ukoliko shvate da postoji veća vjerojatnost da neće osvojiti izbore počnu primjenjivati politiku državne potrošnje kao zalog za neke buduće izbore. Naime, potrošnjom političari koji su na vlasti, na kraju mandata stvaraju dugove koji sljedećoj vladi postaju problem koji je ona najčešće primorana rješavati ne bi li započeti ciklus potrošnje države, a time i dug stavila pod kontrolu. Politika štednje koju poduzima vlast koja nasljeđuje neodrživi dug utječe na stvaranje fronte otpora skupina u društvu koje su bile dobitnici pokrenutog ciklusa potrošnje, uključujući i sindikate. Zato se u kontekstu neoliberalne ideologije i neoliberalnog diskursa o politici štednje, demokracija smatra jednim od glavnih krivaca za stvaranje duga i osviještenog otpora neoliberalnim politikama, a takav se razvoj događaja nastoji spriječiti zagovaranjem takozvanih velikih koalicija od kojih se onda očekuje konsenzus oko kreiranja i provođenja neoliberalnih politika, osobito politike austeriteta, odnosno štednje.

Zanimljiva je strategija poslodavaca kada su se našli suočeni s otporom sindikata koji su proveli referendum o generalnom štrajku, odnosno štrajku solidarnosti s najavama daljnjih sindikalnih akcija zajedno s najavom prikupljana potpisa za peticiju pokretanja prijevremenih izbora. Nakon snažnijeg iskazivanja nezadovoljstva sindikata u javnom diskursu, od poslodavaca se počinje značajnije promicati teza da su izmjene Zakona o radu beznačajne, da neće imati nikakav učinak na zapošljavanje, ali da imaju simboličku vrijednost pokazivanja koraka prema društvu/ekonomiji koja je ustrojena na način da pogoduje poslovnom sektoru, čiji se interes u okviru neoliberalnog diskursa smatra interesom cijelog društva. Dakle predložene promjene imaju određenu vrijednost, ali ne onoliku koliku im pridaju sindikati s argumentom da su radnici u izmjenama mogli proći i mnogo gore.

U diskursu o fleksibilizaciji tržišta rada prisutni su i oponirajući diskursi kojima se nastoje osporiti proklamirani ciljevi reforma na tržištu rada kroz deregulaciju, odnosno 
fleksibilizaciju radnih odnosa. Oponirajući diskursi u određenoj mjeri osporavaju legitimnost provođenja predlaganih promjena ponajviše dovodeći u pitanje unitarističko shvaćanje interesa poslodavaca i radnika te ukazujući na to da je predstavljena fleksibilizacija tržišta rada zamišljena na način da najviše pogoduje poslodavcima. U javnom diskursu prisutno je ukazivanje na negativne posljedice fleksibilizacije koja znači smanjivanje zaštite radnika, ponajviše zaštite radnika od otkaza. Istovremeno se propituju u javnom diskursu iznesene teze da će radnici osjetiti pozitivne posljedice fleksibilizacije, a ističu se aspekti fleksibilizacije koji se negativno odražavaju na radnike. Alternativna rješenja koja se spominju u javnom diskursu za probleme na tržištu rada kao što je na primjer rastuća nezaposlenost su politika potrošnje, odnosno manje restriktivna fiskalna politika kao kejnzijanska alternativa neoliberalnoj politici štednje.

Argumentacija koja naglašava suprotstavljenost interesa poslodavca i radnika izravno oponira diskursu o fleksibilizaciji kao nacionalnom interesu. Sindikati u javnom diskursu o fleksibilizaciji tržišta rada ističu da se promjene koje su uvode izmjenama Zakona o radu zapravo donose bez pravih konzultacija sa sindikatima kao predstavnicima radnika. Predstavnici sindikata izražavaju drugačije shvaćanje značenja socijalnog partnerstva, i to kao načina da se zajednički donose prijedlozi koji bi se trebali ostvarivati kao mjere na tržištu rada s ciljevima oko kojih se mogu usuglasiti svi dijelovi društva, odnosno poslodavci i zaposlenici. U javnom diskursu ponajviše sindikalni čelnici, ali i predstavnici opozicije ukazuju zapravo na fluidnost značenja socijalnog partnerstva i konsenzusa, kao praznih označitelja. Ključno pitanje koje se ovdje postavlja odnosi se na sam sadržaj promjena oko kojih je potrebno ostvariti konsenzus i tko zapravo određuje koje promjene predstavljaju zajednički interes. U tom smislu sindikati instrumentom štrajka dobivaju veći prostor u javnom diskursu ukazujući na nemogućnost uspostave socijalnog dijaloga zbog isključivog stava, prvenstveno države, odnosno političkih elita. Kao ilustracija mogu poslužiti sljedeći primjeri iz tekstova u kojima je prepoznata strategija socijalnog partnerstva kao način da se utišaju sindikati, pri čemu se krivnja za propast socijalnog dijaloga prebacuje na suprotstavljenu stranu:

Nakon što su prekinule pregovore o Zakonu o radu, sindikalne središnjice objavile su jučer i da izlaze iz Gospodarskog socijalnog vijeća.

Ispred Banskih dvora zatražili su jučer i ostavku ministra rada i mirovinskog sustava Miranda Mrsića jer, tvrde, jednostrano nameće rješenja u novom ZOR-u. 
Već idući tjedan kreću sa sindikalnim akcijama u kojima ne isključuju ni generalni štrajk. Prva akcija biti će prosvjedni skup koji će se na Markovu trgu održati u četvrtak, 5. prosinca, kada se očekuje da će Vlada uputiti u Hrvatski sabor izmjene ZOR-a. Sindikalci optužuju Vladu da je nevjerodostojan pregovarač, jer je već usuglašena rješenja jednostrano promijenila.

(G. Galović, Jutarnji list, 29.11.2013.)

„Namjerno lažete kada obrazlažete ovaj zakon. Pozivate na konsenzus, kako? Uzmi ili ostavi, ovaj prijedlog morate prihvatiti $i$ to je po vašem mišljenju konsenzus “, poručio je Lesar ministru.

(Dragutin Lesar, Večernji list, 27.2.2014.)

Pet sindikalnih središnjica predložilo je danas predsjedniku Vlade Zoranu Milanoviću, da Vlada, kao predlagatelj, povuče Prijedlog Zakona o radu iz procedure kako bi se osiguralo vrijeme potrebno za prikupljanje podataka $i$ dokaza te za izradu analiza potrebnih za stručne rasprave, javlja Hina. Zauzvrat, sindikati neće organizirati nikakve industrijske akcije, odnosno štrajkove, u vezi sa ZOR-om.

Milanoviću su to ponudili čelnici sindikalnih središnjica - Krešimir Sever, Mladen Novosel, Vilim Ribić, Ozren Matijašević i Damir Jakuš. Štoviše, sindikati su, kažu čelnici, spremni na povratak $i$ aktivno djelovanje u tijela tripartitnog socijalnog dijaloga, a žele ući u radnu skupinu koja će se baviti izradom Prijedloga Zakona.

„Naš prijedlog trebao bi biti zanimljiv premijeru Milanoviću jer omogućava socijalni dijalog. Zakon o radu važno je pitanje, Vladi zasigurno nisu prihvatljivi nesigurni uvjeti rada, štrajkovi, prosvjedi te organizirani ili spontani nemiri “, ističu sindikalni čelnici.

Podsjećaju Milanovića da je Prijedlog novog Zakona o radu upućen $u$ Hrvatski sabor bez postizanja konsenzusa sa sindikatima. „Ne možemo pristati na koncept Zakona o radu koji se sada nalazi u proceduri“, poručuju sindikalisti.

(Prema S. Bolanča, Jutarnji list, 11.2.2014.) 
Sindikati u okviru ove argumentacije propituju legitimnost Vlade da provodi politike fleksibilizacije prvenstveno održavanjem referenduma o općem štrajku među članstvom, samim štrajkom, ali i mogućnošću pokretanja peticije za raspisivanje izbora, koja predstavlja vrhunac političkog sukoba između predstavnika sindikata i političkih elita.

\subsubsection{Diskurs socijalne države}

Ukoliko je neoliberalni argument onaj koji naglašava da je potrebno osloboditi tržište rada utjecaja države koja zakonskim intervencijama onemogućuju njegovo slobodno funkcioniranje, kao i monopola sindikata na tržištu rada, onda je protuargument da kada to isto tržište ne bi bilo upotpunjeno institucijama koje štite radnike, ali i stvaraju poslodavcima dodatne troškove koje moraju izdvajati za rad, na tržištu rada bi došlo do pojave monopsonije koja je srodna pojavi monopola. Tito Boeri i Jan van Ours (2008) ukazuju na to da smanjivanjem regulacije tržišta rada, u slučajevima visoke stope nezaposlenosti (koja nije, niti može biti uzrokovana samim radnim zakonodavstvom) tržišta postaju izložena zatajenju u obliku monopsonije. Naime, u određenim sektorima industrije ili usluga, zbog nedostatka institucionalne zaštite radnika, može doći do situacije u kojoj poslodavci namještaju naknade za rad koje su ispod kompetitivne razine kako bi povećali razinu profita. Monopsonistička moć podrazumijeva stanje u kojem kupac zahvaljujući svojoj moćnijoj poziciji na tržištu određuje cijenu po kojoj želi kupiti neku robu. Kod monopola, cijena proizvoda nije određena vrijednošću na tržištu već ju određuje onaj koji prodaje robu jer ima monopolistički položaj na tržištu. Na tom su tragu argumenti koji zagovaraju regulaciju tržišta rada kako bi se očuvala zaštita radnika od tržišnih mehanizama koji, ukoliko nisu regulirani institucijama, naginju u korist poslodavaca zbog utjecaja karakteristika svojstvenih slobodnom tržištu. Uzimajući u obzir neki oblik spomenutog argumenta, na sljedeći se način u javnom diskursu izjašnjava i tadašnji ministar financija Slavko Linić, koji smatra da nema potrebe dodatno deregulirati i olakšati proceduru otpuštanja:

„, Mislim da nisu potrebne bitne intervencije u Zakon o radu kada je u pitanju mogućnost otpuštanja. Od početka krize dosad je, prema nekim računicama, broj zaposlenih smanjen za 188.000“, kazao je Linić u intervjuu za Slobodnu Dalmaciju (...).

(S. Linić prema: Ljubica Gatarić, Večernji list, 3.1.2014.) 
„Koga plašimo ako je 250 tisuća radnika već ostalo bez posla od 2008. godine, ako se praksa da se prekovremeni rad ne evidentira i ne plaća sada želi ozakoniti, ako radnici neće smjeti ni pitati rade li prekovremeno, a poslodavac će radno vrijeme nivelirati tako da im to neće biti ni jasno? “, pita Mladen Novosel, šef SSSH.

Nije fleksibilnost hrpa mogućnosti i stalno nova zapošljavanja, već uvijek privremeni posao i lako otpuštanje, a dok posla ima, radno vrijeme nije jasno ograničeno $i$ nije jasno kada je radnik u prekovremenom radu. Agencije za privremeno zapošljavanje dobivaju šire mogućnosti pa će biti sve više takvog privremenog, neizvjesnog i jeftinijeg rada, upozoravaju sindikalci.

(Mladen Novosel prema: Romana Kovačević Barišić, Večernji list, 26. 1. 2014.)

Argumentacija društvene nejednakosti odnosi se na tvrdnje da će fleksibilizacija koja je usredotočena na pojeftinjenje cijene rada, a koja se u javnom diskursu označava kao porast kompetitivnosti i poboljšanje poduzetničke klime, stvoriti velike socijalne razlike u hrvatskom društvu. Ključne značenjske jedinice koje ukazuju na navedenu argumentaciju, kao jedan od protuargumenata fleksibilizaciji, jesu „osiromašenje”, „društvena nejednakost”, „raslojavanje”.

Pupovac je upozorio i da sve ,, zemlje koje su pokleknule pred neoliberalnom mantrom o rezanju, štednji, otpuštanju $i$ fleksibilizaciji rada bilježe rast nejednakosti i nezaposlenosti. “

(Milorad Pupovac, Večernji list, 1.3.2014.)

Predsjednik HDZ-a Tomislav Karamarko, nakon jučerašnjeg sastanka s čelnicima pet sindikalnih središnjica, u Središnjici HDZ-a poručio je da njegova stranka ne podupire Zakon o radu. „HDZ će zatražiti njegovo povlačenje iz saborske procedure jer bi o u sadašnjem obliku, poremetio ravnotežu međuodnosa rada i kapitala“, jedan je od zaključaka sa sastanka. U HDZ-u su uvjereni da bi izmjene, umjesto rasta zaposlenosti i gospodarskog oporavka, donijele još veće socijalno raslojavanje. 
(Tomislav Karamarko, Večernji list, 21.2.2014.)

„Izmjene Zakona o radu neće dovesti do zapošljavanja. Dapače, sve analize pokazuju suprotno. Pa kako pri zdravoj pameti vjerovati da će se povećanjem radnih sati otvarati nova radna mjesta? Liberalizirani zakoni o radu, koje nisu pratile mjere poput zbrinjavanja nezaposlenih i jakih socijalnih mjera, samo su doveli do pojačanog jaza između bogatih i siromašnih. Zato se Zakon o radu uopće ne treba mijenjati. “

(Krešimir Sever, Jutarnji list, 27. 2. 2014.)

„Prođe li taj prijedlog, umjesto godine dana, agencijski bi radnici na istim radnim mjestima mogli raditi do tri godine, a otvara se i mogućnost da rade za nižu plaću“, kaže Mladen Novosel iz SSSH. Sve je više primjera po tvrtkama da agencijski radnici rade za bitno manje plaće od radnika tvrtki koje ih angažiraju, a kad im istekne ugovor, ostaju bez primanja čak $i$ ako imaju ugovor o stalnom radnom odnosu u agenciji.

(Mladen Novosel prema: Ljubica Gatarić, Večernji list, 16.1.2014.)

Argumentacija politike državne potrošnje čini tvrdnje koje se temelje na kejnzijanskoj ekonomici kao temelju osmišljavanja i provođenja ekonomskih politika, u koje se između ostalog ubrajaju i politike na tržištu rada. Argumentacija politike potrošnje predstavlja oponirajući moment u javnom diskursu koji se suprotstavlja neoliberalnom zagovaranju politike štednje i restrukturiranja kao odgovora na gospodarsku krizu, ali i krizu na tržištu rada. Nasuprot neoliberalnim načelima poduprijete politike štednje, zagovornici kejnzijanizma i socijalne države traže ekonomski rast utemeljen na poticanju potrošnje, pri čemu je naglasak na smanjivanju socijalnih nejednakosti, većim pravima i zaštiti radnika te labavijoj fiskalnoj i eventualno monetarnoj politici. U kontekstu javnog diskursa o fleksibilizaciji tržišta rada, nalazimo tvrdnje da fleksibilizacija tržišta rada, osobito aspekti koji se odnose na olakšavanje otpuštanja radnika i restrukturiranje, neće proizvesti željene ekonomske ili socijalne učinke, već je za smanjivanje nezaposlenosti i ekonomski napredak potrebno raditi na povećanju potrošnje. Samih tvrdnji u kojima se kazivači pozivaju na kejnzijansku ekonomiku povećanja 
potrošnje kao alternative fleksibilizaciji za poboljšanje situacije na tržištu rada spomenuta je svega nekoliko puta u uzorku.

\subsection{Analiza zastupljenosti argumentacija po akterima}

\subsubsection{Javni diskurs sindikata o fleksibilizaciji tržišta rada}

Najveći oponenti diskursu neoliberalizma jesu sindikati kao industrijski akteri, koji zastupaju argumentaciju koja se protivi smanjivanju radničkih prava u kontekstu deregulacije tržišta rada s ciljem smanjivanja indeksa zakonske zaštite zaposlenja. U protuargumentima neoliberalnoj argumentaciji konkurentnosti najzastupljenija je argumentacija koja ukazuje na to da predložena fleksibilizacija ide $\mathrm{u}$ korist poslodavaca, odnosno kapitala, ističući sukobljenost interesa između rada i kapitala. Ta se argumentacija ne bavi samim sadržajima fleksibilizacije, ne bavi se njezinim mogućim negativnim posljedicama, već je u središtu zanimanja zapravo način na koji se nastoji provesti sama deregulacija: odnos koji poslodavci i Vlada imaju prema sindikatima neposredno, a posredno i prema radnicima koje sindikati zastupaju.

Sindikati u nešto manjoj mjeri promiču diskurs socijalne države, politike potrošnje, većih prava radnika, radnih zaštita, stabilnog zaposlenja, a postoje i marginalni slučajevi neoliberalne interdiskurzivnosti, odnosno kada diskurs sindikata sadrži i određene neoliberalne elemente. Iako bi bilo očekivano da sindikati zastupanju najvećim dijelom upravo elemente javnog diskursa koji se zalažu za zaštitu radnika i protivljenje neoliberalnim politikama ističući i neka alternativna tumačenja krize, $u$ datom uzorku to izostaje, pa prema nalazima analize djeluje kao da se sindikati zapravo bave sami sobom.

\subsubsection{Javni diskurs poslodavaca o fleksibilizaciji tržišta rada}

Kada poslodavci zastupaju svoje interese, koji su zapravo interesi kapitala, jasno je da kod njih prevladava transparentni neoliberalni diskurs koji se ponajviše ogleda $u$ argumentaciji imperativa konkurentnosti i ekonomske učinkovitosti, odnosno retorike slobodnog tržišta. Za diskurs je poslodavaca karakteristično zalaganje za načela, ponajprije za načelo konkurentnosti koji čini dio retorike slobodnog tržišta. Mada se rijetko može naći da poslodavci izrijekom ističu slobodno tržište kao vrijednost u smislu isticanja slobode koje ono omogućava u odnosu na državnu regulaciju kako je ono osobito isticano u kontekstu neoliberalne doktrine, jasno je vidljivo promicanje načela konkurentnosti kao sredstva kojim se ostvaruje ekonomska 
učinkovitost na tržištu rada. Naime, sindikati u javnom diskursu češće ističu pojedinačne slučajeve prema kojima se smanjuju prava radnika, ali manje načelno zalaganje za vrijednosti socijalne države, dok je kod poslodavaca konsenzus oko podupiranja konkurentnosti prikazan kao nešto što iz principa predanosti ekonomskoj efikasnosti valja podržati. Možda bi se moglo doći do zaključka da se na taj način zamagljuje ili prikriva interes poslodavaca koji se ostvaruje kroz deregulaciju tržišta rada, a to je niža cijena rada na teret radnika. U kontekstu argumentacije o konkurentnosti, ona se osobito povezuje s privlačenjem ulaganja, to jest stranim investicijama. Pa se tako za poslodavce pretjerana reguliranost tržišta rada pojavljuje kao jedna od prepreka stranim ulaganjima, mada ju ne navode kao najveću prepreku, već tek jednu od mnogih barijera ulaganjima, među kojima su i administrativne barijere (zamršenost postupaka dobivanja dozvola), korupcija i slično.

O svih navedenih argumentacija koje čine neoliberalni diskurs poslodavci dominantno preuzimaju argumentaciju konkurentnosti. Zanimljivo je da poslodavci u manjoj mjeri pozivaju na argument restrukturiranja, osobito kada je riječ o restrukturiranju u privatnom sektoru, pa je tako svega nekoliko primjera, pretežno od istog izvora, koji pozivaju na restrukturiranje, odnosno otpuštanje u javnom sektoru, iako su jasno artikulirani zahtjevi poslodavaca za olakšavanje procedure otpuštanja za male poduzetnike.

Poslodavci dominiraju i u zahtjevima za modernizacijom Zakona o radu, gdje fleksibilizacija zapravo za njih predstavlja korak u smjeru modernizacije radnih odnosa, pri čemu se često ističe hrvatsko zaostajanje za drugim zemljama Europske unije u mogućnostima koje se nude kod fleksibilnog zapošljavanja te se ističe neprimjerenost postojećeg Zakona o radu koji je po njihovim riječima rigidan, zastario, neprilagođen vremenu u kojem živimo pa stoga i dio te argumentacije predstavlja i tvrdnja da rigidno radno zakonodavstvo smanjuje aktivnosti na tržištu rada koje bi trebale ići u smjeru rasta zapošljavanja.

Argumentacija stvaranja ljudskog kapitala kao pozitivne posljedice fleksibilizacije tržišta rada, odnosno podređivanje obrazovnog sustava potrebama poslodavaca, kao i poticanje radnika da o svojim vještinama razmišljaju kao o kapitalu dio je neoliberalnog diskursa u njegovu najoriginalnijem obliku, i jedan od najoriginalnijih doprinosa neoliberalizma ekonomskoj teoriji uopće, kako je to istaknuo i Michel Foucault (2008). U cjelokupnom udjelu argumentacija kojima se nastoji legitimirati proces fleksibilizacije kao olakšavanje poslovanja i smanjivanje prava radnika, argument ljudskog kapitala kojim se nastoji ustvrditi da je fleksibilizacija zapravo dobra za radnike jer im omogućuje da imaju slobodu odlučivanja na koji će način odlučiti razvijati svoje vještine kako bi bili konkurentni na tržištu rada; nešto što 
prema neoliberalnim tezama organizirani rad, to jest sindikati, na neki način obeshrabruju jer se zalažu za zaštitu radnika i stalna radna mjesta. Stalnošću radnog mjesta, odnosno jakim zaštitama na tržištu rada, rad, prema neoliberalnom viđenju ostvaruje monopolističku poziciju na tržištu rada i uvođenjem regulacije tržišta rada zapravo onemogućuje radnike da ostvaruju individualne, samostalne odluke. Udio u neoliberalnim argumentacijama koje zauzima argumentacija ljudskog kapitala relativno je mala, međutim, takvu argumentaciju u javnom diskursu dominantno zastupaju poslodavci. Prisutno je zalaganje za individualno odlučivanje radnika o vlastitom stjecanju vještina i osposobljavanju i to na način da te procjene pozitivno utječu na radnikovu poziciju na tržištu rada, odnosno da vještine radnika budu što prilagođenije potrebama poslodavaca, pa da se u skladu s tim investicijama u ljudski kapital na tržištu najpravednije raspodjeljuju nagrade. Iako poslodavci to vrlo rijetko eksplicitno ističu, sindikati, odnosno organizirani rad za njih zapravo ima ulogu u ometanju ovog procesa, jer je njegova uloga izboriti se za pravedniju raspodjelu nagrada i materijalnih naknada na tržištu rada koja vrijedi za skupine ljudi, a ne za pojedince. Zato kada se u okviru argumentacije ljudskog kapitala ističe vrijednost ostvarivanja individualnih koristi za radnika, koje regulacija onemogućuje, onda to predstavlja i implicitnu kritiku sindikata.

Jedna od argumentacija koju također snažno promiču poslodavci jest argumentacija zajedničkog ili nacionalnog interesa koji je svrstan u neoliberalni diskurs jer podrazumijeva da su interesi poslodavaca istovjetni interesima radnika, pa se na taj način zanemaruju negativne socijalne implikacije fleksibilizacije koja ide u smjeru snižavanja cijene rada, s krajnjim ciljem „poboljšanja poduzetničke klime“, to jest pojeftinjenja poslovanja. Također je u navedenoj argumentaciji prisutna i snažna kritika sindikata jer se protive prijedlozima kapitala te ih se proziva da narušavaju socijalni dijalog i da ne pristaju na prijeko potrebni konsenzus koji je od nacionalne važnosti. Međutim, poslodavci zapravo ne nude konkretan kompromis, koji bi predstavljao ustupke u zamjenu za svoje zahtjeve. Poslodavci jednostavno traže konsenzus oko ustupaka koji se podrazumijevaju i očekuju od radnika, odnosno od sindikata, a ti ustupci zapravo niti nisu predmet rasprave, već mogu biti samo veći ili manji. Dakle, argumentacija nacionalnog interesa $\mathrm{u}$ javnom diskursu o fleksibilizaciji tržišta rada dio je neoliberalnog diskursa u njegovu donekle eufemiziranom obliku, jer se sindikati kroz navedenu argumentaciju neizravno kritiziraju, premda postoje i primjeri izravnih napada na sindikate.

Na prethodnu argumentaciju nadovezuje se i argumentacija nezaposlenosti pri čemu i poslodavci sudjeluju u javnom diskursu o fleksibilizaciji time što ukazuju na to da je tada aktualni Zakon o radu zapravo uzrok nezaposlenosti te da prestroga regulacija tržišta rada 
onemogućuje napredak gospodarstva, pa time dolazi do povećanja nezaposlenosti. Poslodavci se ne usredotočuju u tolikoj mjeri na to je li postojeći Zakon o radu, odnosno prevelika reguliranost tržišta rada povezana s rastućom stopom nezaposlenosti i općenito nepovoljnim trendovima na tržištu rada.

Poslodavci promiču neoliberalni diskurs konkurentnosti, jeftinije cijene rada, prebacivanja tržišnih rizika s poslodavaca na državu te sa sustava na pojedinca, smanjivanje troškova države u obliku smanjivanja broja zaposlenih u javnom sektoru, percepciju uloge države u službi uspostavljanja okoline pogodne za poslovanje i obrazovanja u službi poslodavaca te antagonizam prema sindikatima kroz primorani konsenzus kao nacionalni interes, a ne stvarni kompromis.

\subsubsection{Javni diskurs predstavnika Vlade o fleksibilizaciji tržišta rada}

U diskursu Vlade blago dominiraju argumentacije koje se mogu povezati s neoliberalnim diskursom. Postoje određeni elementi argumentacija koje se odnose na zaštitu radnika, pa u tom smislu mogu predstavljati i diskurs socijalne države, međutim, ti su imperativi kada je u pitanju javni diskurs predstavnika Vlade, podređeni imperativu konkurentnosti i restrukturiranja.

Općenito je za diskurs Vlade karakteristično da se politika fleksibilizacije tržišta rada ne nastoji legitimirati na neki specifičan način, što možda nije niti iznenađujuće s obzirom na to da Vlada ima političku moć provoditi određene politike sa ili bez podrške socijalnih partnera. Vlada također provodi politiku fleksibilizacije na preporuku međunarodnih, nadnacionalnih organizacija, kao i Hrvatske narodne banke, svjetskih rejting agencija, preporuka Europske komisije te na temelju međunarodnih pokazatelja ili indeksa konkurentnosti i slično.

Najznačajniji argument koji se spominje u kontekstu Vladinog diskursa o fleksibilizaciji jest fleksibilizacija s ciljem restrukturiranja privatnih kompanija i nešto manje strukturnih reformi u javnom sektoru. Argumentacija kojom se legitimira zagovaranje olakšavanja postupka otpuštanja, to jest smanjenja cijena otpuštanja jest omogućavanje privatnim kompanijama u financijskim problemima da uz što manje troškove prilagode kvantitetu radne snage vlastitim mogućnostima poslovanja. Argumentacija restrukturiranja ustanovljena je na tvrdnjama da je upravo zbog visokih troškova otpuštanja došlo do propasti velikog broja tvrtki, koje su onda morale snositi troškove rada koji su bili visoki, što ih je dovelo do bankrota, čime su „propala sva radna mjesta“. U ovoj se argumentaciji nemogućnost olakšanog ili povoljnog otpuštanja radnika navodi kao uzrokom ili barem jednim od uzroka propadanja kompanija, 
mada se takav razvoj događaja mnogo suvislije može povezati s gospodarskom krizom koja je, između ostalog, i zbog smanjenje potrošnje dovela do smanjenja potražnje za proizvodima i uslugama.

Vlada također zastupa argumentaciju konkurentnosti i to globalne konkurentnosti cijene rada. Smanjenjem cijene rada u globalnim okvirima, prema Vladinim procjenama, trebalo bi doći do povećanja investicija u Hrvatsku i do ,pokretanja gospodarstva u Hrvatskoj“. S tom je argumentacijom povezana i argumentacija nezaposlenosti jer se naglascima na investicije ukazuje na to da će investicijama doći do otvaranja radnih mjesta.

Kao protuargument ovim tezama može se navesti analiza Goste Esping-Andersena (2000) koji ističe da fleksibilizacijom tržišta rada, odnosno pojeftinjenjem cijene rada u načelu ne dolazi do smanjivanja agregatne nezaposlenosti, već može doći do demokratizacije statusa nezaposlenih. Dakle ono što se može dobiti ovakvim reformama jest fleksibilnije tržišta rada na kojem svi radnici lakše dobivaju otkaze. Međutim, pretpostavka je da su fleksibilnija tržišta rada protočnija, da radnici lakše gube posao, ali ga lakše i nalaze, između ostalog i zbog jeftinije cijene rada i hipoteze da će jeftini rad povećati potražnju na tržištu rada, pa će ti radnici lakše naknadno naći posao, iako će taj posao biti za koji stupanj nesigurniji, a materijalna prava i naknade za radnike će se u prosjeku smanjiti.

Vlada u javnom diskursu nastoji isticati i pozitivne strane fleksibilizacije kao što je zaštita radnika koja bi se trebala ostvarivati u obliku lakšeg pronalaženja posla i smanjene mogućnosti otpuštanja za one koji ostanu u privatnim kompanijama koje su opstale zahvaljujući restrukturiranju odnosno jeftinijem otpuštanju. Vlada u javnom diskursu nastoji balansirati između neoliberalnog diskursa i diskursa socijalne države, i to u maniri Trećeg puta, odnosno ordoliberalne paradigme socijalnog tržišta pri čemu se ono što je pristajanje na uvjete kapitala prikazuje kao pragmatični konsenzus koji pogoduje svima u jednakoj mjeri; poslodavcima jer imaju jeftinije uvjete rada, odnosno ,povoljniju poduzetničku klimu“, radnicima jer će u Hrvatskoj biti ,više posla“. 


\section{ANALIZA POLITIKA NA TRŽIŠTU RADA}

Promjene radnog zakonodavstva iz 2013. i 2014. godine tek u posljednjih nekoliko godina pokazuju posljedice koje je fleksibilizacija imala na hrvatsko tržište rada i hrvatskog radnika. Cilj je ovog rada bio ustanoviti u kojoj je mjeri uvođenje fleksibilnosti u radne odnose bilo odraz odnosa moći u javnom diskursu i je li ono doista prevagnulo u korist poslodavaca, a na štetu radnika ukoliko je neoliberalna vizija tržišta rada u javnom diskursu bila ona koja je prevladala i koja se je preslikala na radno zakonodavstvo. Prema glavnim promjenama koje su provođene i oko kojih su se u javnosti vodili prijepori, možda su najznačajnije bile promjene koje se tiču rada posredstvom agencija za privremeno zapošljavanje. Promjene u regulaciji radnog vremena i povećanje maksimalnih sati prekovremenog rada u sezonskim poslovima, kao i djelomična liberalizacija otkaza nije se toliko odrazila na zapošljavanje ili povećano otpuštanje, kao niti na povećanje zaposlenosti mladih, i to zbog odlaska velikog broja radnika iz Hrvatske koji su dobili bolje plaćeno zaposlenje u nekoj od zemalja Europske Unije. Tako da danas, za mnoge sektore, a osobito one s manje plaćenim radnim mjestima, postoji nedostatak radne snage s obzirom na to da je i kvaliteta tih poslova dosta niska uzevši u obzir koje se pogodnosti osim plaće, ako ikakve, nude radnicima. Kao što je ranije navedeno, s većom fleksibilizacijom tržišta rada dolazi i do povećanja udjela radnih mjesta slabije kvalitete (Esping-Andersen 2000), pa je u kontekstu hrvatske radne realnosti fleksibilizacija tržišta rada imala višestruke negativne učinke. Ne samo da je pogoršala situaciju za ljude koji već rade na slabije plaćenim poslovima, nego je povećala udio takvih poslova koje danas u Hrvatskoj malo tko želi prihvatiti. Okolnosti su takve da u zemljama Europske unije postoji potražnja za radnicima odgovarajućih kvalifikacija u koje Hrvati odlaze u potrazi za poslom zbog daleko boljih uvjeta osiguranih bolje reguliranim tržištima rada. Danas je u Hrvatskoj situacija pomalo paradoksalna jer je fleksibilizacija stvorila radna mjesta koja nitko zapravo ne želi, a možda nasreću, niti mora prihvatiti, a što je, da ironija bude veća, bila prvobitna intencija izmjena Zakona, odnosno da se radnik dovede u status da mora prihvatiti sve što mu se nudi kako bi se na taj način povećala razina zaposlenosti.

\subsection{Analiza izmjena zakonodavnog okvira}

Nakon javne rasprave koja je trajala od početka 2013. godine i koja je obuhvaćala koordinaciju prijedloga izmjena Zakona o radu; lobiranje poslodavaca, prijedloge Vlade i protuprijedloge sindikata, sredinom 2014. godine postignut je dogovor između industrijskih aktera o odredbama Zakona o radu. Izmjene zakona o radu su, kao i posljednje značajnije 
izmjene iz 2003. godine, išle u smjeru deregulacije određenih aspekata rada kako bi se smanjio OECD-ov indeks radnozaštitnog zakonodavstva i ne bi li se Hrvatska bolje pozicionirala na ljestvicama međunarodnih institucija koje služe kao pokazatelj troškova rada u Hrvatskoj. Može se dakle ustvrditi da je zamišljena reforma išla u smjeru snižavanja cijene rada, odnosno pojeftinjenja uvjeta poslovanja. S obzirom na to da snižavanje cijene rada pretpostavlja smanjenje materijalnih prava i zaštite radnika, bilo je važno opravdati takve izmjene. S jedne se strane legitimacija izmjena koju su nudili zagovaratelji fleksibilizacije svodila na vrlo jednostavnu, neki bi rekli odviše simplificiranu tvrdnju da će snižavanjem cijene rada, ili kako je u to u diskursu češće artikulirano fleksibilizacijom tržišta rada „modernizacijom“ Zakona o radu, doći do smanjivanja nezaposlenosti, odnosno do otvaranja radnih mjesta (EspingAndersen 2000). To je česta tvrdnja u kontekstu legitimacije neoliberalnih politika na tržištu rada koja se oslanja na neoliberalni zahtjev uvođenja ,više tržišta“ u odnose između rada i kapitala $\mathrm{i}$ to oslobađanjem tržišta rada od institucija koje štite radnika od potencijalno eksploatacijske moći poslodavca. Prema neoliberalnom pogledu na tržište rada, koji zanemaruje složenost društvenih odnosa koji okružuju i uvjetuju situaciju na tržištu rada, niska potražnja za radom na tržištu može se rješavati snižavanjem njegove cijene. Osim navedenog pojednostavljenog razmišljanja o radu u terminima karakterističnima za tržišta, pri čemu se ustvrđuje da će spuštanje cijene rada rezultirati većom potražnjom, drugi je aspekt legitimacije predloženih promjena bila tvrdnja da će se navedenim reformama ojačati zaštite radnika, iako se nije točno odredilo na što se konkretno mislilo kada je bila riječ o jačanju zaštita radnika u samoj radnoj regulativi.

\subsubsection{Izmjene koje se odnose na mogućnosti numeričke fleksibilnosti}

Većina zahtjeva za reformama na tržištu rada izmjenama Zakona o radu odnosila se na povećanje numeričke fleksibilnosti, odnosno na mogućnost poslodavaca da s obzirom na promjene u potražnji prilagode svoj radni proces na način da smanje troškove rada smanjujući broj zaposlenika u poduzeću. U tom su smislu prijedlozi izmjena Zakona o radu išli za tim da se na razne načine olakša prilagodba poslodavaca postojećoj gospodarskoj krizi, odnosno da im se u budućnosti olakša proces takozvanog restrukturiranja. Što se tiče povećanja razine numeričke fleksibilnosti, reformama se na nekoliko načina djelovalo u smjeru olakšavanja otpuštanja i to pojednostavljivanjem postupka kolektivnog otpuštanja za poslodavce i otkazivanjem ugovora o radu nakon probnog roka. Numerička se fleksibilnost također povećala i proširivanjem mogućnosti zapošljavanja i izvan temeljnog i općeg načina rada po ugovoru na neodređeno, i to izmjenama regulacije atipičnih oblika rada koji se odnose na ugovore s 
agencijama za privremeno zapošljavanje prema čl. 44, 45, 46, 47, 48, 49, 50, 52, Zakona o radu, (NN 93/14), ugovor o radu na određeno vrijeme prema čl. 12 i 13 Zakona o radu, (NN 93/14) te ugovor o radu na nepuno radno vrijeme prema čl. 63 Zakona o radu, (NN 93/14). Navedeni oblici rada podrazumijevaju smanjivanje troškova potencijalnog otpuštanja, odnosno lakšeg restrukturiranja tvrtki i prilagodbi danim tržišnim uvjetima, kako se to najčešće u datim novinskim tekstovima navodi. Osim atipičnih oblika rada, izmjena koja može poslodavcima smanjiti troškove otpuštanja i zapošljavanja radnika jest uvođenje mogućnosti ustupanja radnika između povezanih poslodavaca.

Druga u javnom diskursu spominjana proširenja numeričke fleksibilizacija bila su mogućnost otkazivanja ugovora o radu bez ikakvog obrazloženje radnicima zaposlenima kod malih poduzetnika, smanjivanje troškova otpuštanja smanjivanjem iznosa otpremnina te uvođenje dodatnih, često nespecificiranih atipičnih oblika rada koji smanjuju troškove zapošljavanja, odnosno otpuštanja kao što su ugovori u kojima nije specificirano radno vrijeme, takozvani zero-hours ugovori. Ti oblici fleksibilizacije nisu uvršteni u izmjene Zakona o radu, tako da se može ustvrditi da ovako ekstremna fleksibilizacija tržišta rada koja bi sadržavala odredbe mogućnosti otkazivanja ugovora o radu bez obrazloženja ipak nije ostvarena, mada su neke druge odredbe o kojima će kasnije biti riječi dovele do ekstremne fleksibilnosti u nekim drugim oblicima zapošljavanja i rada u Hrvatskoj.

\section{Otkazivanje ugovora o radu tijekom probnog rada}

Novost koja se uvela u novi Zakon o radu bilo je olakšavanje otkazivanja ugovora o radu tijekom trajanja probnog roka koje je, kao i u prijašnjem Zakonu o radu, ograničeno na maksimalnih 6 mjeseci. Institut probnog roka ima svrhu da poslodavcu osigura provjeru radnikovih stručnih sposobnosti i druge karakteristike koje se odnose na mogućnost ispunjavanja zahtjeva određenog posla, ali i da se sam radnik upozna s organizacijskim okruženjem i uvjetima rada te očekivanjima poslodavca. S obzirom na to da je smisao probnog roka da poslodavac utvrdi kompatibilnost sposobnosti radnika s povjerenim poslovima, odluka o opstanku radnog odnosa ovisi o ispunjavanju očekivanja poslodavca, koji u slučaju da ta očekivanja izostanu, može otkazati ugovor o radu do isteka probnog roka prema članku 53., stavka (3) Zakona o radu koji glasi: „Nezadovoljavanje radnika na probnom radu predstavlja posebno opravdan razlog za otkaz ugovora o radu. “ Unatoč tome što je olakšano otpuštanje radnika za vrijeme trajanja probnog roka, takav otkaz ugovora o radu trebao bi biti popraćen obrazloženjem iz kojeg se opravdanog razloga poslodavac smatra da radnik na probnom radu nije zadovoljio (Crnkić 2014). Ako bi u zakonu bila izostavljena obaveza obrazloženja otkaza, 
tada bi se radniku uskratila mogućnost bilo kakvog osporavanja otkazivanja ugovora o radu na sudu, zbog čega je također zaustavljena dogovorena izmjena Zakona koja bi omogućavala malim poduzetnicima otkazivanje ugovora o radu bez obrazloženja, i to zbog neusklađenosti s Europskim direktivama koje isključuju tu mogućnost zbog uskraćivanja jednakog prava na pristup sudu. Međutim, Crnkić (2014) ističe kako postoje i tumačenja ove odredbe u Zakonu o radu prema kojima opravdanost razloga otkazivanja ugovora o radu tijekom trajanja probnog rada ne može biti predmetom ispitivanja tijekom sudskog postupka.

Ne postoji dostupan izvor podataka o eventualnim statistikama koje se tiču zadovoljavanja ili nezadovoljavanja radnika na probnom radu. Međutim, pretpostavljamo da se ova mogućnost ne zloupotrebljava kao način smanjivanja broja zaposlenih bez troškova, jer postoji mogućnost zapošljavanja po ugovoru na određeno za svega nekoliko mjeseci, odnosno u trajanjima koja su razmjerom istovjetna trajanju probnog rada. Dapače, nezadovoljavanje tijekom probnog rada za poslodavce predstavlja dodatan vremenski i financijski trošak.

\section{Pojednostavljivanje postupka kolektivnih otkaza ugovora o radu}

U novom je Zakonu o radu i 2014. godine za poslodavce olakšan postupak kolektivnog otpuštanja radnika. Naime, u novom Zakonu ne postoji obaveza izrade programa zbrinjavanja viška radnika od poslodavca. Ukoliko poslodavac namjerava otkazati ugovor o radu najmanje 20 radnika, o tome je dužan pravodobno obavijestiti radničko vijeće. U savjetovanju s radničkim vijećem, odnosno nakon što se radničko vijeće očituje o namjerama poslodavaca, poslodavac je dužan razmotriti očitovanje te razmotriti i obrazložiti razloge koji uvjetuju potrebu kolektivnog otkaza te mogućnosti koje bi mogle otkloniti potrebe kolektivnog otkazivanja ugovora o radu prema članku 127. Zakona o radu (Milković 2014). Obaveza poslodavca da razmotri očitovanje radničkog vijeća nije postojala u prijašnjem Zakonu o radu, a zakonodavac ju je dodao kako bi dao veću važnost radničkom vijeću u slučaju kolektivnog viška radnika. Milković (2014) smatra da je to uvedeno kao posljedica ukidanja obveze poslodavčeve izrade programa zbrinjavanja viška radnika kao neka vrsta obaveze koja je ipak manja od spomenutog programa propisanog prijašnjim Zakonom o radu.

\section{Uvođenje mogućnosti prestanka ugovora o radu trudnicama i drugim zaštićenim kategorijama osoba}

U ranijim verzijama Zakona o radu, postojala je apsolutno zaštićena kategorija radnika koji gotovo ni u kojim okolnostima nisu mogli biti otpušteni, što se odnosilo na trudnice. Sve zaposlene trudnice, bilo da su zaposlene na ugovor na neodređeno ili određeno uživaju zaštitu 
od otkaza kako bi se trudnice zaštitilo od spolne diskriminacije. Novi Zakon o radu, međutim, predviđa poteškoće s apsolutnom zabranom otkaza za vrijeme trudnoće, korištenja rodiljnog, roditeljskog i posvojiteljskog dopusta u koje vrijeme poslodavac ne smije otkazati ugovor. Zato je u novom Zakonu uvedena mogućnost otkaza trudnicama u slučajevima ,poslovno uvjetovanih razloga tijekom provedbe postupka likvidacije prema posebnim propisima“ (Vinković 2014). Preciznije, to znači da ugovor o radu trudnice može biti otkazan smrću poslodavca kao fizičke osobe, zatim u slučaju da je obrt okončan po sili zakona te kada je trgovac pojedinac brisan iz sudskog registra. Navedene se izmjene mogu smatrati nekom vrstom fleksibilizacije radnih odnosa, međutim prijašnji propisi ipak nisu pratili realnost hrvatske gospodarske situacije s obzirom na to da trudnicama nije bili moguće otkazati ugovor o radu čak ni u slučaju smrti vlasnika poduzeća ili pak likvidacije.

\section{Uvođenje mogućnosti ustupanja radnika između poslodavaca koji su povezani}

U novom je Zakonu o radu uvedena mogućnost ustupanja radnika između povezanih poslodavaca. Naime, ukoliko poslodavac na određeni period nema potrebu za radom nekog radnika, on ima mogućnost ustupiti radnika drugom povezanom poslodavcu. Povezanost poslodavaca uređena je Zakonom o trgovačkim društvima. Ovakvo rješenje omogućuje poslodavcima da uštede na troškovima otpuštanja radnika, i to u slučajevima kada je status radnog procesa u kojem je rad radnika nepotreban samo privremenog karaktera te poslodavac očekuje da će u dogledno vrijeme opet imati posla za radnika kojeg će nakon toga vratiti na prvobitno radno mjesto. Ustupanje radnika vremenski je ograničeno na 6 mjeseci. Tijekom ustupanja, radnik mora raditi cjelokupno ugovoreno radno vrijeme kod drugog povezanog poslodavca. Dakle poslodavcu nije dopušteno koristiti ovu mogućnost na način da radnik, na primjer, nekoliko dana radi kod prvog poslodavca, a ostatak radnog tjedna kod drugog. Jedan od uvjeta ustupanje je i pisana suglasnost radnika s ustupanjem drugom poslodavcu.

\section{Zapošljavanje putem agencija za privremeno zapošljavanje}

Kao što je već navedeno, regulacija djelovanja agencija za privremeno zapošljavanje na hrvatskom tržištu rada uvedena je izmjenama Zakona o radu 2003. godine. Iako u to vrijeme rad agencija nije izazivao velike prijepore između socijalnih partnera, to jest nije izazivao značajnije protivljenje sindikata, najnovija izmjena radnog zakonodavstva izazvala je negativne reakcije sindikalnih čelnika. Ta se diskrepancija možda može pripisati činjenici da prije prve izmjene nije bilo nikakvih referentnih iskustava hrvatskih radnika u tim agencijama, dok je naknadna liberalizacija njihova rada izazvala polemike i protivljenja sindikata jer su raspolagali 
informacijama koje su ukazivale na nejednak tretman agencijskih radnika i stalno zaposlenih radnika kod istog poslodavca te na česte zlouporabe ovog oblika rada kada su radnici kod istog poslodavca mogli raditi i dulje od jedne godine, na način da bi im agencija samo promijenila naziv radnog mjesta za koje ih je ustupala poslodavcu.

Agencije za privremeno zapošljavanje poslodavcima omogućuju ustupanje radnika za pojedine poslove. Poslodavci na taj način ne moraju s radnicima sklopiti izravan ugovor već imaju ugovor s nekom od agencija za privremeno zapošljavanje. U tom kontekstu, kako bi se na neki način proširio oblik zapošljavanja radnika preko agencija za privremeno zapošljavanje, Vlada je pristala na zahtjeve sindikata da se rad preko agencija u određenim aspektima prava iz radnog odnosa izjednači s pravima radnika s ugovorom na određeno. S druge strane, trajanje radnog odnosa koje je moguće ugovoriti s agencijom za privremeno zapošljavanje povećano je $\mathrm{s}$ jedne na tri godine kako bi se i u tom aspektu taj radni odnos izjednačio s onim koji je utemeljen na ugovoru na određeno.

Promjene koje su se dogodile u regulaciji rada preko agencija uključivale su povećanje vremenskog razdoblja tijekom kojeg agencijski radnik može biti zaposlen kod istog poslodavca $\mathrm{s}$ jedne godine na tri godine čime je došlo do horizontalnog usklađivanja s odredbama o ograničenju trajanja ugovora o radu na određeno vrijeme.

Što se tiče utjecaja promjena navedene politike na hrvatsko tržište rada upravo uvođenjem ovakvog oblika rada, one su bile možda najdalekosežnije od svih uvedenih promjena utoliko što su hrvatsko tržište rada učinile izrazito fleksibilnim, a počele su predstavljati i ogledni primjer negativnosti koje donose mjere fleksibilizacije kada se ne provode vodeći računa o dugoročnim učincima na radnika, kao i o promjenjivom globalnom kontekstu. Europska je komisija stoga tijekom 2016. godine upozoravala na to da agencije iz zemalja poput Hrvatske ustupaju radnike u zemlje Europske unije gdje oni rade za često mnogo nižu plaću od radnika koji su ondje stalno zaposleni. Stoga je Europska komisija u ožujku 2016. godine predlagala izmjenu Direktive 96/71/EZ ne bi li izjednačila plaće agencijskih radnika s plaćama tamošnjih radnika. Hrvatska je bila protiv predloženih promjena, tako da je na saborskom Odboru za europske poslove jednoglasno odbacila upućenu direktivu, međutim, Europska komisija tu direktivu nije doradila već je njezin sadržaj prihvaćen u izvorno predloženom obliku. Kao razlog odbacivanja izmjena direktive, zemlje članice koje su se na to odlučile, odnosno Bugarska, Češka, Rumunjska, Slovačka, Poljska, Danska, Estonija, Latvija, Litva, Mađarska i Hrvatska, bio je taj da bi na taj način poduzeća tih zemalja izgubila konkurentnost na međunarodnom tržištu. Motiv koji je posve u skladu s ranijim protivljenjima 
stvaranju zajedničkog europskog okvira regulacije radnog zakonodavstva (Deakin i Wilkinson 1994).

Agencije za privremeno zapošljavanje postoje u Hrvatskoj od 2003. godine, ali su nakon izmjena Zakona o radu 2013. i 2014. godine počele intenzivnije djelovati na hrvatskom tržištu rada. Prema stavku (7), članka 44. Zakona o radu (NN, br. 93/14), agencije su dužne Ministarstvu rada i mirovinskog sustava dostavljati statističke podatke o obavljanju poslova na temelju ugovora o ustupanju radnika, odnosno ustupanja radnika drugom poslodavcu za privremeno obavljanje poslova. Nakon uvođenja fleksibilnosti u radne odnose donošenjem Zakona o radu 2014. godine, zapošljavanje preko agencija za privremeno zapošljavanje značajno se proširilo na hrvatskom tržištu rada. Prije izmjena, odnosno 2013. godine, radnika zaposlenih preko agencija za privremeno zapošljavanje bilo je 1098, i bili su u najvećem dijelu zaposleni na neodređeno vrijeme. Nakon nekoliko godina, odnosno na kraju 2016. godine, taj broj se povećao 18 puta i porastao na 19327 radnika koji su, prema podacima koje je Ministarstvo rada i mirovinskog sustava dostavilo Novom listu, većinom bili zaposleni na određeno vrijeme (Gabrijela Galić, Novi list, 5. 7. 2017.). Broj radnika zaposlenih preko agencija za privremeno zapošljavanje naglo je porastao nakon izmjena Zakona o radu, odnosno već 2014. godine, kada je taj broj iznosio 13462 radnika, odnosno već tada 12 puta više nego u prethodnoj godini i svi su bili zaposleni na određeno vrijeme, a 2015. godine prema dostavljenim podacima zaposlenih preko agencija bilo je 16444, od kojih je 207 bilo zaposleno na neodređeno vrijeme. Prema dostupnim podacima broj zaposlenih u agencijama 2016. godine, dosegnuo je svoj vrhunac sa 19327 radnika, od kojih je 343 bilo zaposleno na neodređeno. Agencije za privremeno zapošljavanje nisu dostavile podatke o zapošljavanju za 2017. godinu. Ministarstvo rada i mirovinskog sustava tek je 2019. godine javno objavilo (nepotpun) izvještaj o radu agencija za privremeno zapošljavanje za 2018. godinu. Naime, od ukupno 187 agencija, 114 ih je dostavilo izvješća, što je nešto manje od dvije trećine. U izvješću su dani podaci o ukupnom broju zaposlenih u agencijama kao i njihova spolna, dobna i obrazovna struktura. Također, istaknut je podatak da je od ukupno 18159 ustupljenih radnika samo njih 466 ustupljeno u inozemstvo, što i nije začuđujuće s obzirom na to da su im prava u inozemstvu izjednačena s pravima tamošnjih radnika, ali i s obzirom na to da je hrvatskim radnicima relativno jednostavno pronaći posao u inozemstvu bez posredovanja agencija zbog velike potražnje za radnom snagom u nekim zemljama Europske unije. Ono što je zanimljivo u izvještaju Ministarstva rada i mirovinskog sustava je to da je većina radnika koji su zaposleni u agencijama za privremeno zapošljavanje, a koje su predale godišnji izvještaj, zaposleno na 
ugovor na određeno. U 114 agencija za privremeno zapošljavanje u Republici Hrvatskoj, od ukupnog broja sklopljenih ugovora u 2018. godini koji iznosi 27095, njih 26434 sklopljeno je na određeno vrijeme, a 661 ugovor je sklopljen na neodređeno vrijeme (MRMS 2019).

TABLICA 8.1 Ustupljeni radnici zaposleni na određeno vrijeme (prilagođeno prema izvješću MRMS, 2019.)

\begin{tabular}{|c|c|c|c|c|c|c|}
\hline \multicolumn{3}{|c|}{ Trajanje ugovora ustupljenih radnika } & \multicolumn{2}{c|}{$\begin{array}{c}\text { Radno vrijeme ustupljenih } \\
\text { radnika }\end{array}$} \\
$\begin{array}{c}\text { Do 3 } \\
\text { mjeseca }\end{array}$ & $\begin{array}{c}3 \text { do } 6 \\
\text { mjeseci }\end{array}$ & $\begin{array}{c}6 \text { do } 12 \\
\text { mjeseci }\end{array}$ & $\begin{array}{c}\text { Više od } \\
12 \\
\text { mjeseci }\end{array}$ & $\begin{array}{c}\text { Prosječno } \\
\text { trajanje } \\
\text { ugovora } \\
\text { (G/M/D) }\end{array}$ & Puno & Nepuno \\
\hline 7317 & 4005 & 3763 & 4045 & $0 / 6 / 1$ & 17260 & 947 \\
\hline
\end{tabular}

Napomena: Ukupan zbroj ugovora ustupljenih radnika nije isti jer su neki od radnika ustupljeni po više ugovora o radu.

U Tablici 8.1 razvidno je da u dostavljenim izvješćima, najveći broj ustupljenih radnika radi puno radno vrijeme, što upućuje na to da su sindikati bili u pravu kada su rekli da će, u nekim aspektima jeftiniji agencijski radnici, postati zamjena redovitim radnicima u tvrtkama kojima ovi prvi bivaju ustupljeni. Prema izvještaju Ministarstva rada i mirovinskog sustava, prosječno trajanje ugovora o radu na određenu u agencijama je 6 mjeseci i 1 dan. Ugovori u agencijama sklopljeni na određeno vrijeme, koji po najnovijem uređenju radnog zakonodavstva mogu, ako se sklapaju po prvi put biti sklopljeni na tri godine, na više od 12 mjeseci sklopljeni su u tek $21 \%$ slučajeva, dakle neznatno više od jedne petine, a svi ostali ugovori sklapani su na manje od 12 mjeseci, što upućuje na prilično ekstremnu prekarnost rada u agencijama za privremeno zapošljavanje. Također, iako je u javnom diskursu bilo isticano da će agencije za privremeno zapošljavanje sklapati s radnicima ugovore na neodređeno te će ih ustupati drugim poduzećima, iz dostupnih podataka je razvidno da čak 98\% radnika ima s agencijom ugovor koji je jednakog trajanja kao i trajanje ustupanja, dok samo $2 \%$ ustupljenih radnika ima ugovor dulji od trajanja ustupanja. 


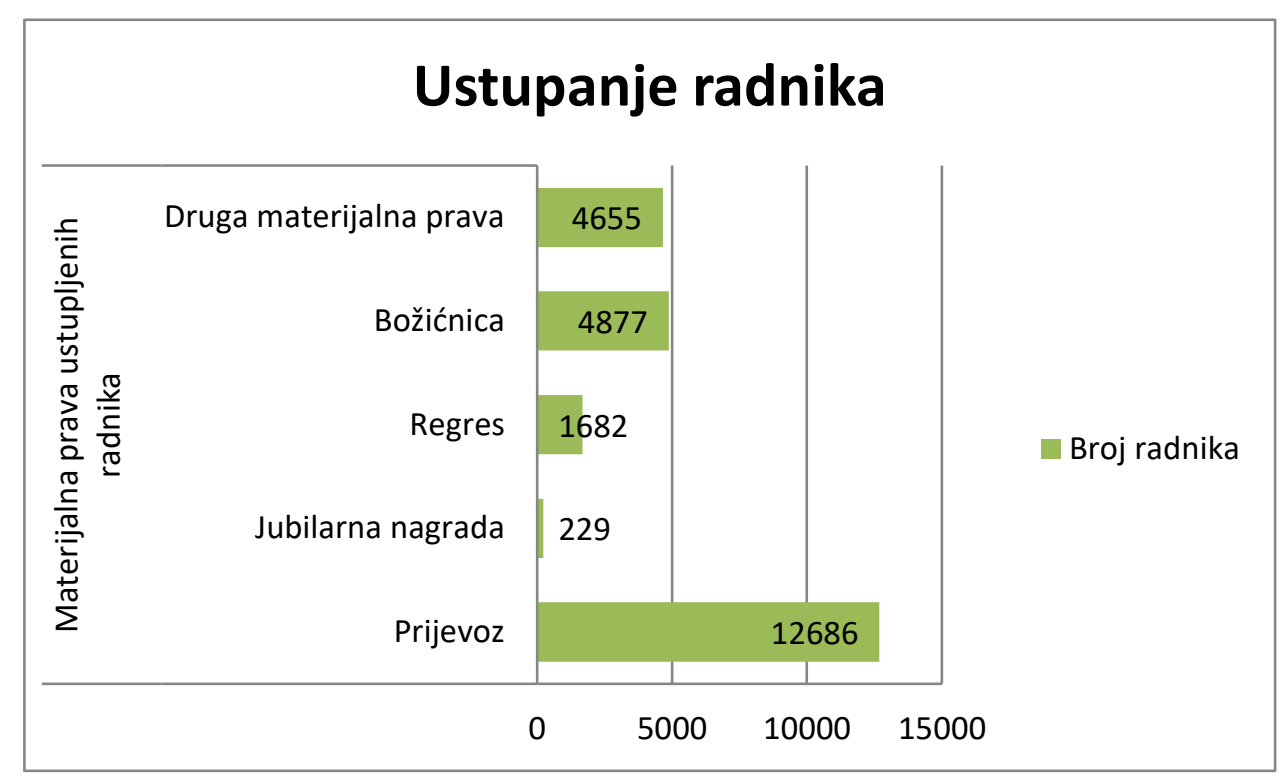

Grafički prikaz 8.1 Materijalna prava ustupljenih radnika

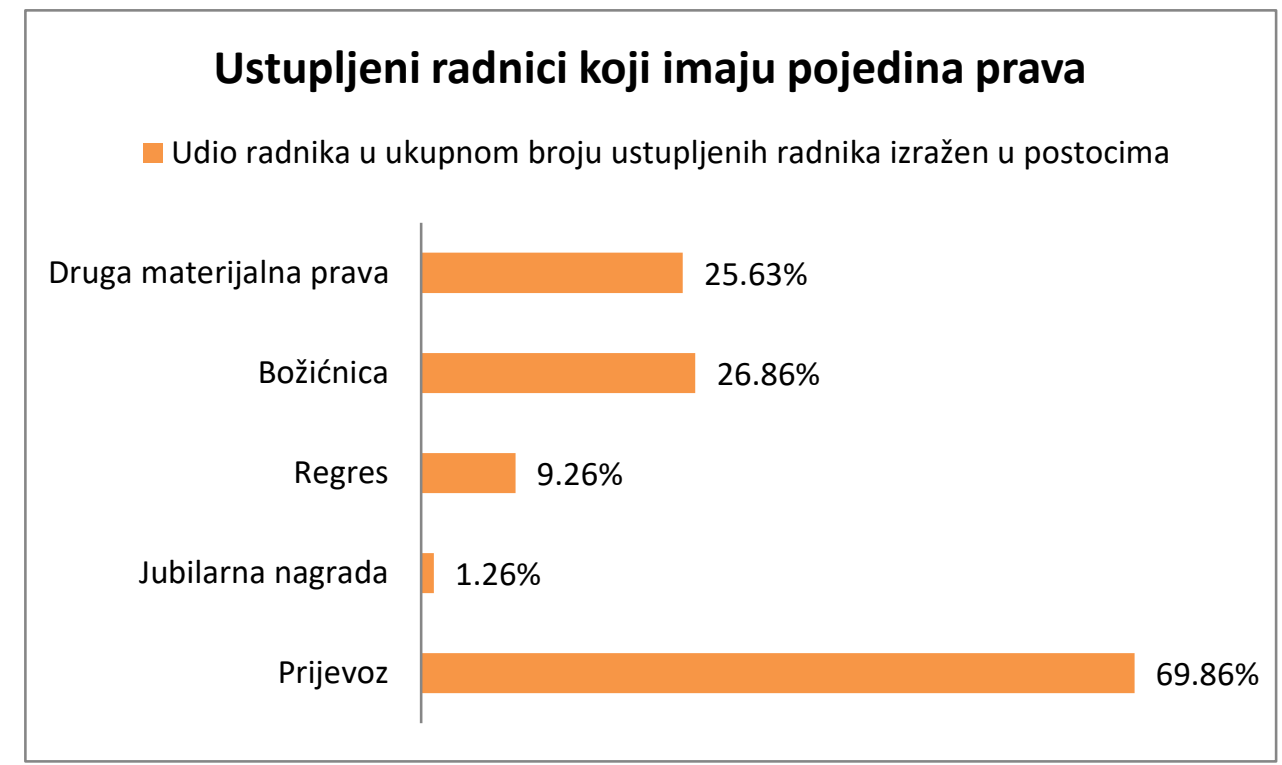

Grafički prikaz 8.2 Materijalna prava ustupljenih radnika (\%)

Kada su sindikati upozoravali na to da će širenje prostora djelovanju agencija za privremeno zapošljavanje dovesti do značajnog porasta udjela prekarnog rada, odnosno do štetnih aspekata fleksibilizacije, u javnom diskursu su se pojavile tvrdnje da će agencije za privremeno zapošljavanje sklapati s radnicima ugovore na neodređeno, koji će imati ista prava kao i radnici zaposleni u samim poduzećima. Kao što se vidi iz dostavljenih podataka, vrlo je malo radnika zaposlenih na neodređeno $\mathrm{u}$ agencijama za privremeno zapošljavanje, odnosno njih manje od 5\%. Po podacima se može zaključiti da su agencije za privremeno zapošljavanje prvenstveno usmjerene na rad na određeno vrijeme, a zaposlenici koji imaju ugovore na neodređeno vjerojatno čine administrativno i drugo operativno osoblje, kao i rukovodeći kadar, odnosno radnike koji obavljaju djelatnost samih agencija za privremeno zapošljavanje. Također su bile 
prisutne i tvrdnje da će ti isti radnici imati sva materijalna prava koja imaju i radnici zaposleni u poduzećima ili javnim službama, međutim iz podataka je razvidno da je većini radnika plaćen tek prijevoz, dok su ima druga prava omogućena u mnogo manjoj mjeri.

Jedan od argumenata za podršku značajnijoj ulozi agencija za privremeno zapošljavanje na hrvatskom tržištu rada bilo je i uspoređivanje hrvatskog stanja udjela agencijskog rada u ukupnoj zaposlenosti s drugim zemljama Europske unije. S obzirom na podatke u Eurostata, uistinu se može reći da je udio agencijskih radnika u ukupnom broju zaposlenih ispod prosjeka Europske unije. Međutim, sam taj argument ne govori ništa o tome kakvi su druge okolnosti i uvjeti rada u agencijama za privremeno zapošljavanje.

TABLICA 8.2 Radnici zaposleni u agencijama za privremeno zapošljavanje izraženo u postocima u Hrvatskoj i Europskoj uniji (Eurostat, 21.5.2019.)

\begin{tabular}{|l|r|r|r|r|r|r|r|r|r|r|}
\hline GEO/TIMe & 2008 & 2009 & 2010 & 2011 & 2012 & 2013 & 2014 & 2015 & 2016 & 2017 \\
\hline $\begin{array}{l}\text { European Union - 28 } \\
\text { countries }\end{array}$ & 1,7 & 1,4 & 1,5 & 1,6 & 1,5 & 1,5 & 1,6 & 1,6 & 1,7 & 1,9 \\
\hline $\begin{array}{l}\text { European Union - 15 } \\
\text { countries (1995-2004) }\end{array}$ & 1,9 & 1,5 & 1,6 & 1,8 & 1,7 & 1,7 & 1,7 & 1,7 & 1,9 & 2,2 \\
\hline Euro area (19 countries) & 2,2 & 1,8 & 2,0 & 2,1 & 2,0 & 2,0 & 2,0 & 2,0 & 2,2 & 2,5 \\
\hline Croatia & 0,7 & 0,8 & 0,6 & 0,6 & 0,9 & 1,2 & 1,0 & 1,1 & 1,2 & 0,7 \\
\hline
\end{tabular}

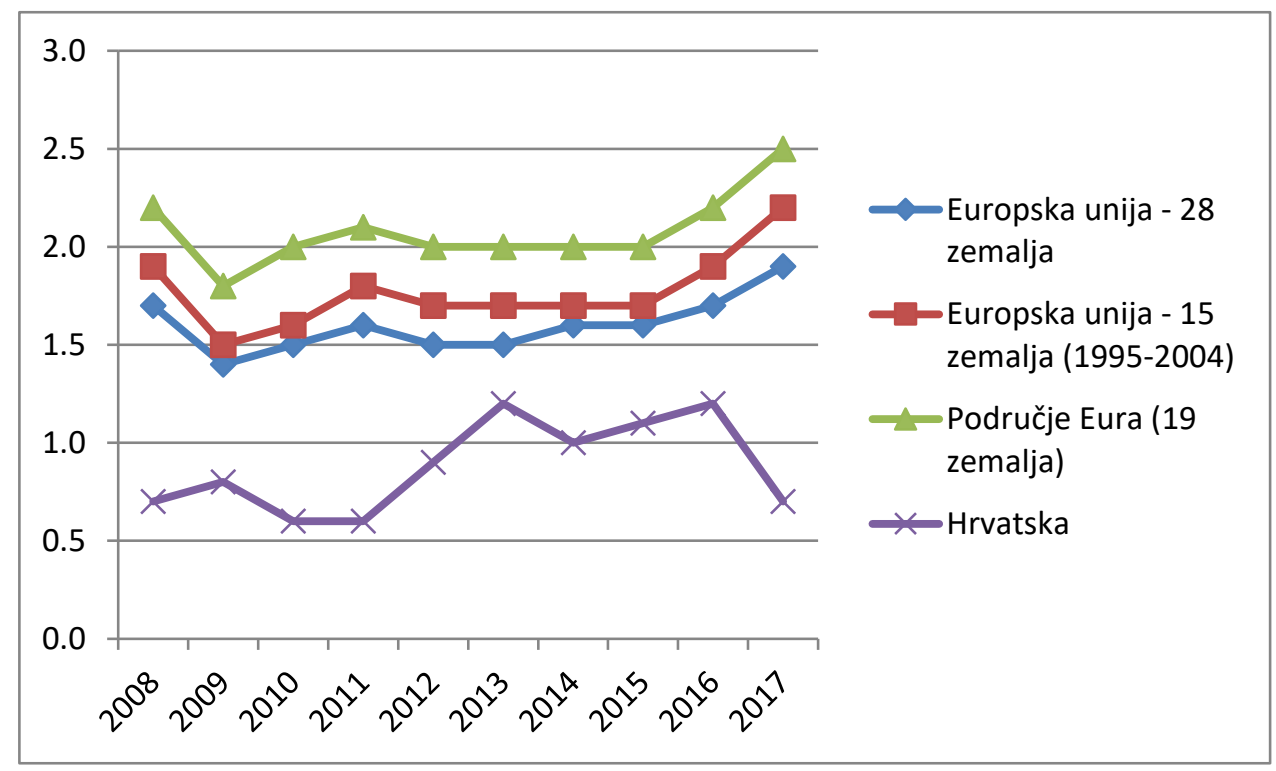

Grafički prikaz 8.3 Radnici zaposleni u agencijama za privremeno zapošljavanje 


\section{Rad na određeno vrijeme}

Predlagane izmjene Zakona o radu u vrijeme iz kojeg dolaze analizirani članci odnosile su se i na promjene u radu na određeno vrijeme, i to promjene čl. 12 st. 2 i čl. 12 st. 3 Zakona o radu (NN 93/14). Promjene koje su se uvele omogućile su šire uporabu ovog nestandardnog oblika rada produljivanjem razdoblja na koje je moguće radnika zaposliti na određeno vrijeme, s time da prvi sklopljeni ugovor o radu na određeno između radnika i pojedinog poslodavca nema vremenskog ograničenja. Zapošljavanjem na određeno vrijeme, poslodavci izbjegavaju trošak otpremnine, kao i druge prepreke otpuštanju radnika, s obzirom na to da se bilo kada mogu odlučiti da više nemaju potrebu za radnikom s kojim su sklopili ugovor na određeno, osobito kada je on sklopljen po prvi puta i bez ograničenja.

Analizom javnog diskursa o fleksibilizaciji tržišta rada nije ustanovljeno značajnije i specifično protivljenje oponirajućih diskursa spomenutim izmjenama koje su se predlagale, za razliku od agencijskog rada koji je naišao na nešto značajnija protivljenja. Rad na određeno je na neki način oduvijek bio omiljeni način zapošljavanja poslodavaca u Hrvatskoj, čemu u prilog govore i podaci iz Mjesečnih statističkih biltena Hrvatskog zavoda za zapošljavanje o izlascima iz evidencije zaposlenosti, kao i dostupni podaci iz Anketa poslodavaca. U Tablici 8.3 vidljivo je kako nakon 2014. godine raste udio radnika zaposlenih na određeno vrijeme, $i$ to sve do 2017. godine, kada se taj udio počinje smanjivati. Ako usporedimo stanje s prosjekom Europske unije, vidljivo je da je u Hrvatskoj ta vrsta fleksibilnog rada zastupljenija za otprilike 5 posto i to upravo od donošenja Zakona o radu 2014. godine, a udio radnika zaposlenih na određeno vrijeme kreće se oko 20 posto, dok je prosjek 28 zemalja Europske unije oko 14 posto. Prije izmjena Zakona o radu, u Hrvatskoj je udio radnika s ugovorom na određeno vrijeme bio oko 13 posto, odnosno za oko 1 posto manje od prosjeka Europske unije.

Tablica 8.3 Udio radnika s ugovorom na određeno vrijeme (izraženo u postocima) (Eurostat, 21.5.2019.)

\begin{tabular}{|c|c|c|c|c|c|c|c|c|c|c|c|c|}
\hline GEO/Godina & 2007 & 2008 & 2009 & 2010 & 2011 & 2012 & 2013 & 2014 & 2015 & 2016 & 2017 & 2018 \\
\hline $\begin{array}{c}\text { Europska Unija - 28 } \\
\text { zemalja }\end{array}$ & 14,4 & 13,9 & 13,4 & 13,7 & 13,9 & 13,7 & 13,5 & 13,9 & 14,0 & 14,2 & 14,4 & 14,0 \\
\hline $\begin{array}{c}\text { Europska Unija - 15 } \\
\text { zemalja (1995-2004) }\end{array}$ & 14,7 & 14,3 & 13,6 & 13,8 & 14,0 & 13,7 & 13,5 & 13,7 & 13,9 & 14,2 & 14,6 & 14,4 \\
\hline $\begin{array}{c}\text { Područje eura (19 } \\
\text { zemalja) }\end{array}$ & 16,2 & 15,9 & 15,1 & 15,3 & 15,5 & 15,1 & 14,9 & 15,2 & 15,5 & 15,7 & 16,2 & 16,1 \\
\hline Hrvatska & 13,2 & 12,3 & 12,0 & 12,8 & 13,5 & 13,3 & 14,5 & 16,9 & 20,2 & 22,1 & 20,6 & 19,9 \\
\hline
\end{tabular}




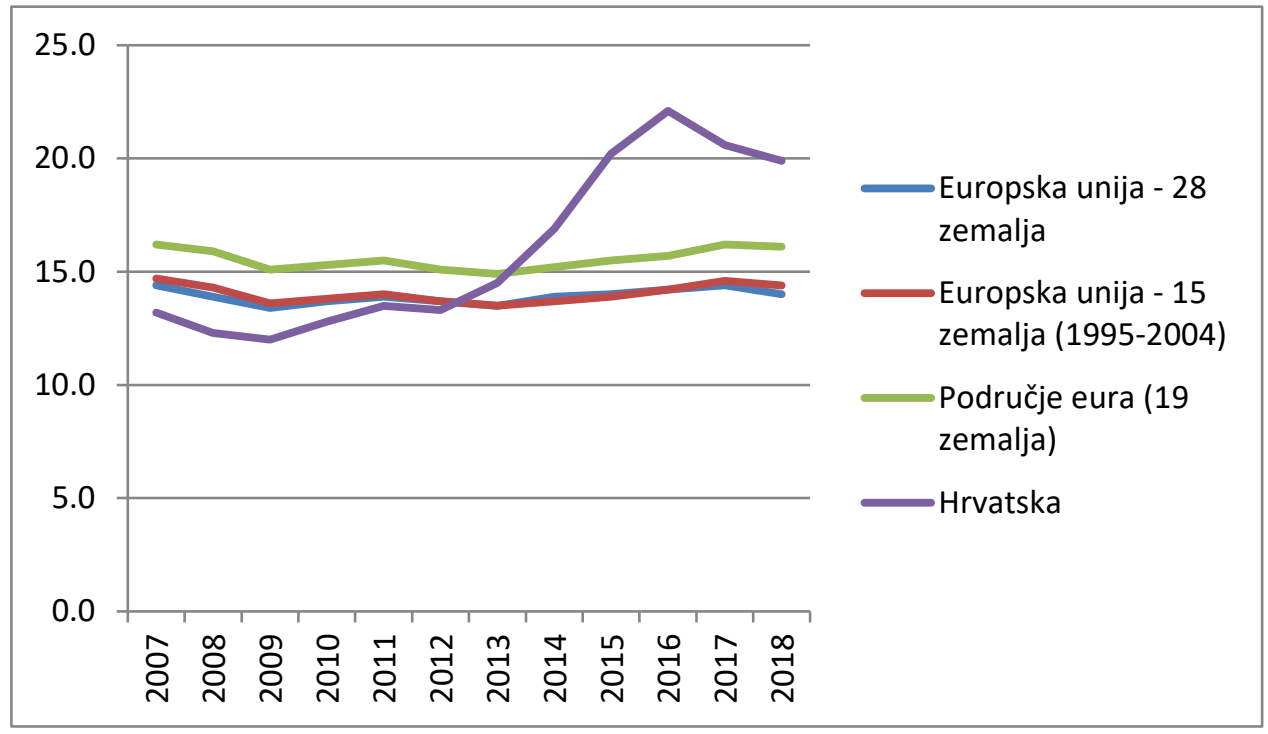

Grafički prikaz 8.4 Udio radnika s ugovorom na određeno vrijeme (Tablica 8.4)

Tablica 8.4 i pripadajući grafički prikaz, izrađeni prema izvješćima Hrvatskog zavoda za zapošljavanje o izlascima iz evidencije nezaposlenosti, također govore u prilog povećanju broja zapošljavanja na određeno vrijeme. Razina zapošljavanja na određeno dosegnula je vrhunac u 2014. godini, kada su također izlasci iz evidencija nezaposlenih zapošljavanjem na neodređeno bili na najnižoj razini u promatranom razdoblju, iako se ta brojka u promatranom razdoblju uglavnom kreće na razini od oko 15 tisuća, dok je 2014. godine njezina razina bila 11685 ugovora na neodređeno što je ujedno i najniža razina za spomenuto razdoblje, što govori u prilog tezi da je, barem u toj 2014. godini fleksibilniji oblik rada na određeno dijelom počeo zamjenjivati temeljni i opći oblik rada na neodređeno vrijeme. Spuštanje razine zapošljavanja na određeno vrijeme tijekom 2017. godine moguće je pripisati i odljevu radne snage iz Hrvatske u zemlje Europske unije, s obzirom na to da ugovori o radu na neodređeno nisu porasli u toliko značajnoj mjeri da bi se time pojasnio pad zapošljavanja na određeno vrijeme. 
TABLICA 8.4 Broj zaposlenih temeljem ugovora o radu prema podacima o izlascima iz evidencije nezaposlenih Hrvatskog zavoda za zapošljavanje u razdoblju između 1.1.2011. i 31.12.2017. (Izvor: Mjesečni statistički bilten HZZ-a i Anketa poslodavaca)

Izlasci iz evidencije Hrvatskog zavoda za zapošljavanje (ugovor o radu)

\begin{tabular}{|c|c|c|c|c|c|c|c|c|c|c|c|c|c|c|}
\hline Godina & \multicolumn{2}{|c|}{2011} & \multicolumn{2}{|c|}{2012} & \multicolumn{2}{|c|}{2013} & \multicolumn{2}{|c|}{2014} & \multicolumn{2}{|c|}{2015} & \multicolumn{2}{|c|}{2016} & \multicolumn{2}{|c|}{2017} \\
\hline Mjesec & Određeno & Neodređeno & Određeno & Neodređeno & Određeno & Neodređeno & Određeno & Neodređeno & Određeno & Neodređeno & Određeno & Neodređeno & Određeno & Neodređeno \\
\hline siječanj & 6579 & 919 & 7108 & 1004 & 9889 & 969 & 10736 & 923 & 10357 & 767 & 10226 & 1044 & 9552 & 1049 \\
\hline veljača & 9050 & 1260 & 7430 & 919 & 10113 & 864 & 11945 & 904 & 11620 & 930 & 12885 & 1305 & 11550 & 1177 \\
\hline ožujak & 13221 & 1767 & 15283 & 1259 & 16847 & 1233 & 17762 & 984 & 18533 & 1305 & 18885 & 1476 & 17851 & 1557 \\
\hline travanj & 19029 & 1617 & 23937 & 1518 & 22332 & 1257 & 26052 & 1127 & 26358 & 1271 & 25565 & 1464 & 20723 & 1570 \\
\hline svibanj & 19863 & 1618 & 23363 & 1430 & 27390 & 1374 & 24996 & 1149 & 25536 & 1359 & 23978 & 1350 & 23744 & 1768 \\
\hline lipanj & 17563 & 1307 & 19586 & 1081 & 21965 & 1038 & 24545 & 899 & 23139 & 1301 & 20810 & 1340 & 17352 & 1329 \\
\hline srpanj & 13867 & 977 & 16767 & 1006 & 19105 & 1201 & 18489 & 875 & 15984 & 1328 & 13261 & 1190 & 11567 & 1154 \\
\hline kolovoz & 9048 & 959 & 9321 & 790 & 10381 & 792 & 9886 & 831 & 10176 & 992 & 9801 & 1091 & 7043 & 953 \\
\hline rujan & 16687 & 1606 & 12198 & 1142 & 12467 & 923 & 14803 & 1159 & 15223 & 1679 & 15728 & 1831 & 13233 & 1753 \\
\hline listopad & 11230 & 1302 & 10946 & 1114 & 11619 & 926 & 12086 & 1053 & 12239 & 1484 & 10356 & 1487 & 9022 & 1415 \\
\hline studeni & 9218 & 1339 & 10062 & 1058 & 9998 & 837 & 11292 & 896 & 11922 & 1550 & 10277 & 1574 & 8536 & 1269 \\
\hline prosinac & 6577 & 928 & 6531 & 682 & 9066 & 934 & 9444 & 885 & 10109 & 1428 & 8872 & 1251 & 11474 & 1234 \\
\hline Ukupno & 151932 & 15599 & 162532 & 13003 & 181172 & 12348 & 192036 & 11685 & 191196 & 15394 & 180644 & 16403 & 161647 & 16228 \\
\hline
\end{tabular}




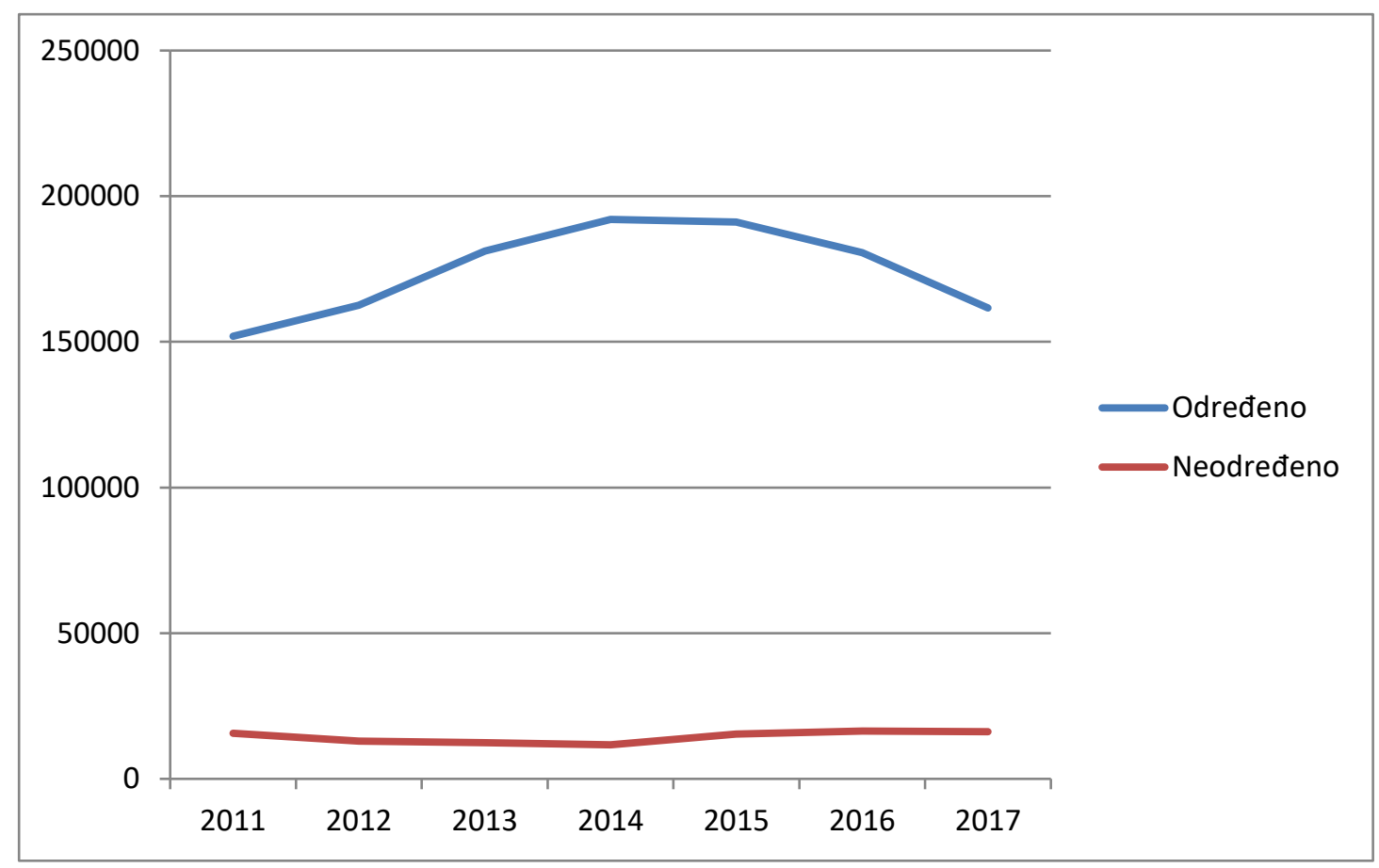

Grafički prikaz 8.5 (Tablica 8.5 )

\section{Sezonski rad}

Kada je u pitanju sezonski rad, poslodavci u turizmu su već pri prvim izmjenama Zakona u radu, odnosno u onima koje su donesene u 2013. godini i koje su onda kao takve prenijete u novi Zakon o radu koji je na snazi od 7. kolovoza 2014. godine, u javnom diskursu dosta snažno zahtijevali neke iznimke u rasporedu radnog vremena za sezonske radnike. Prema stavku 1, članka 74 Zakona o radu (NN 93/14), „tijekom svakog vremenskog razdoblja od dvadeset četiri sata, radnik ima pravo na dnevni odmor od najmanje dvanaest sati neprekidno“. Iznimka koja se odnosi na sezonske radnike odnosi se na čl. 74, st. 2 koji propisuje da je radnicima zaposlenima na sezonskim poslovima koji se obavljaju u dva navrata tijekom dana poslodavac dužan osigurati dnevni odmor od najmanje 8 sati neprekidno. Na taj su način omogućene uštede poslodavcima u turizmu što se tiče broja zaposlenika, jer sezonski radnik na taj način može raditi večernju smjenu, a zatim nakon osmosatnog odmora ponovno raditi u jutarnjoj smjeni. Sezonski su radnici često zaposleni na temelju ugovora na određeno za stalne sezonske poslove, tako da se povećanje udjela rada na određeno može dijelom pripisati i širenju turističke djelatnosti u Hrvatskoj u posljednjih desetak godina. Paralelno s širenje sezonskih poslova, kako u turizmu, tako i u poljoprivredi, uvodi se i mjera aktivne politike zapošljavanja pod nazivom „Stalni sezonac“. Spomenutu mjeru imaju mogućnost koristiti radnici koji su kod istog poslodavca bili kontinuirano zaposleni najmanje šest mjeseci s time da za tog istog poslodavca moraju raditi najmanje tri sezone ili su već radili tri sezone, bez obzira na to jesu li već koristili 
status stalnog sezonca. Ova mjera traje 6 mjeseci, a primjenjuje se na onaj dio godine kada sezonski radnik ne prima plaću niti je prijavljen na mirovinsko osiguranje. Prava stalnih sezonskih radnika regulirana su stavkom 4, članka 18 Zakona o mirovinskom osiguranju (NN 157/13, 151/14, 33/15, 120/16, 18/18, 62/18, 115/18, 102/19, 84/21): „Na produženo osiguranje osigurava se osoba nakon prestanka ugovora o radu na određeno vrijeme za stalne sezonske poslove“, kao i člancima 9 i 126 Zakona o doprinosima (NN 84/08, 152/08, 94/09, 18/11, 22/12, 144/12, 148/13, 41/14, 143/14, 115/16, 106/18). Valja napomenuti da su u Zakon o tržištu rada (NN 118/18) preuzete odredbe prijašnjeg Zakona o posredovanju pri zapošljavanju i pravima za vrijeme nezaposlenosti koje se tiču i prava sezonskih radnika, pa se tako sezonski radnici prijavljeni na produženo osiguranje ne smatraju nezaposlenim osobama prema stavku 11, članka 10 Zakona o tržištu rada (NN 118/18).

\section{Prekarna zaposlenost u Hrvatskoj}

Spomenuti najznačajniji oblici fleksibilne organizacije rada kao što su rad preko agencija za privremeno zapošljavanje, sezonski rad ili rad na određeno vrijeme uopće, doveli su do sklapanja velikog broja ugovora na određeno vrijeme čije trajanje ne prelazi 3 mjeseca. Eurostat je u veljači 2018. godine objavio podatke za 2016. godinu kada je upravo Hrvatsku proglasio zemljom s najvećim udjelom prekarne zaposlenosti među zemljama Europske unije (Grafički prikaz 8.7 - Prekarna zaposlenost 2016), i to s čak 8.4 posto. Po udjelu prekarne zaposlenosti Hrvatsku slijedi Francuska s gotovo dvostruko manjim udjelom od 4.8 posto, zatim Španjolska na 4.7 posto te Slovenija i Poljska s 4.5 posto.

TABLICA 8.5 Prekarni rad (izraženo u postocima) (Eurostat, 21.5.2019.)

\begin{tabular}{|l|r|r|r|r|r|r|r|r|r|r|}
\hline & 2009 & 2010 & 2011 & 2012 & 2013 & 2014 & 2015 & 2016 & 2017 & 2018 \\
\hline Područje/vrijeme & 2,0 & 2,2 & 2,3 & 2,2 & 2,2 & 2,3 & 2,3 & 2,3 & 2,3 & 2,2 \\
\hline $\begin{array}{l}\text { Europska unija - 28 zemalja } \\
\text { (1995-2004) }\end{array}$ & 2,0 & 2,1 & 2,2 & 2,2 & 2,1 & 2,2 & 2,2 & 2,2 & 2,3 & 2,3 \\
\hline $\begin{array}{l}\text { Područje eura (19 zemalja) } \\
\text { Hrvatska }\end{array}$ & 2,2 & 2,4 & 2,5 & 2,4 & 2,3 & 2,5 & 2,6 & 2,6 & 2,7 & 2,6 \\
\hline
\end{tabular}




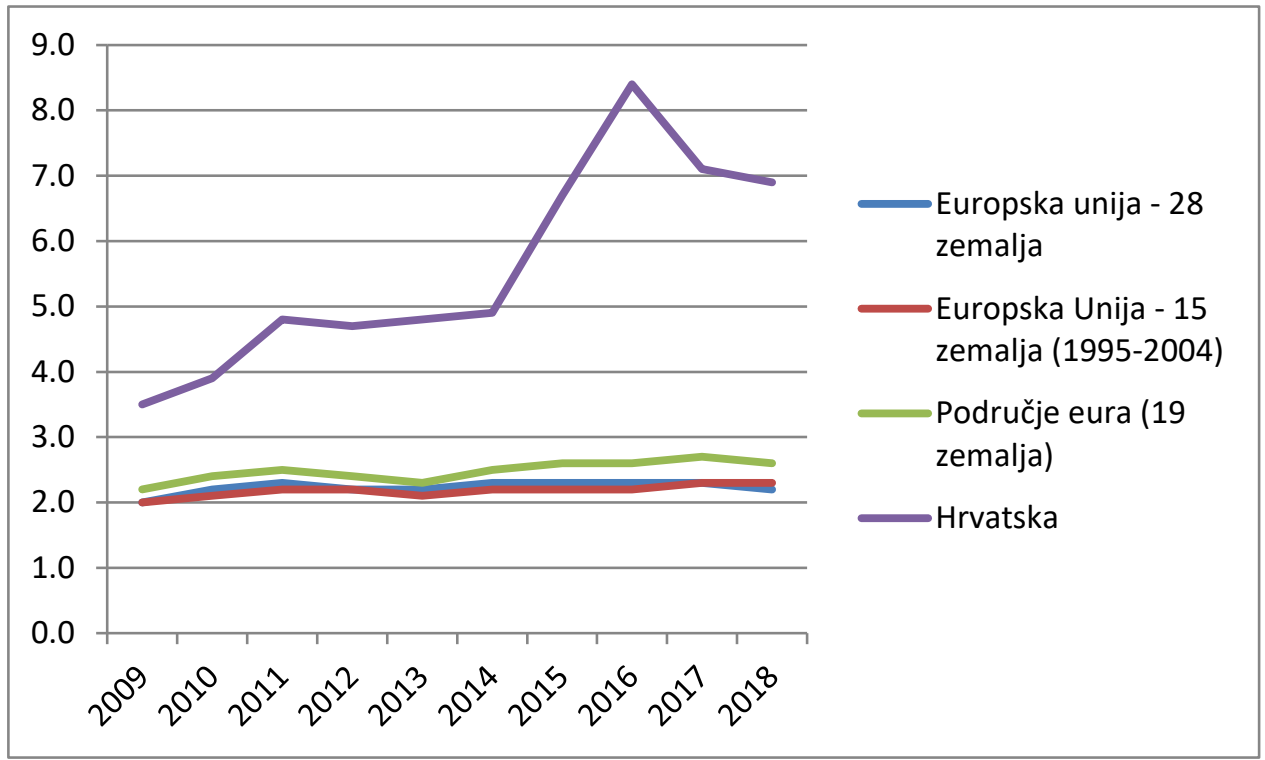

Grafički prikaz 8.6 Prekarni rad u postocima (Tablica 8.6)

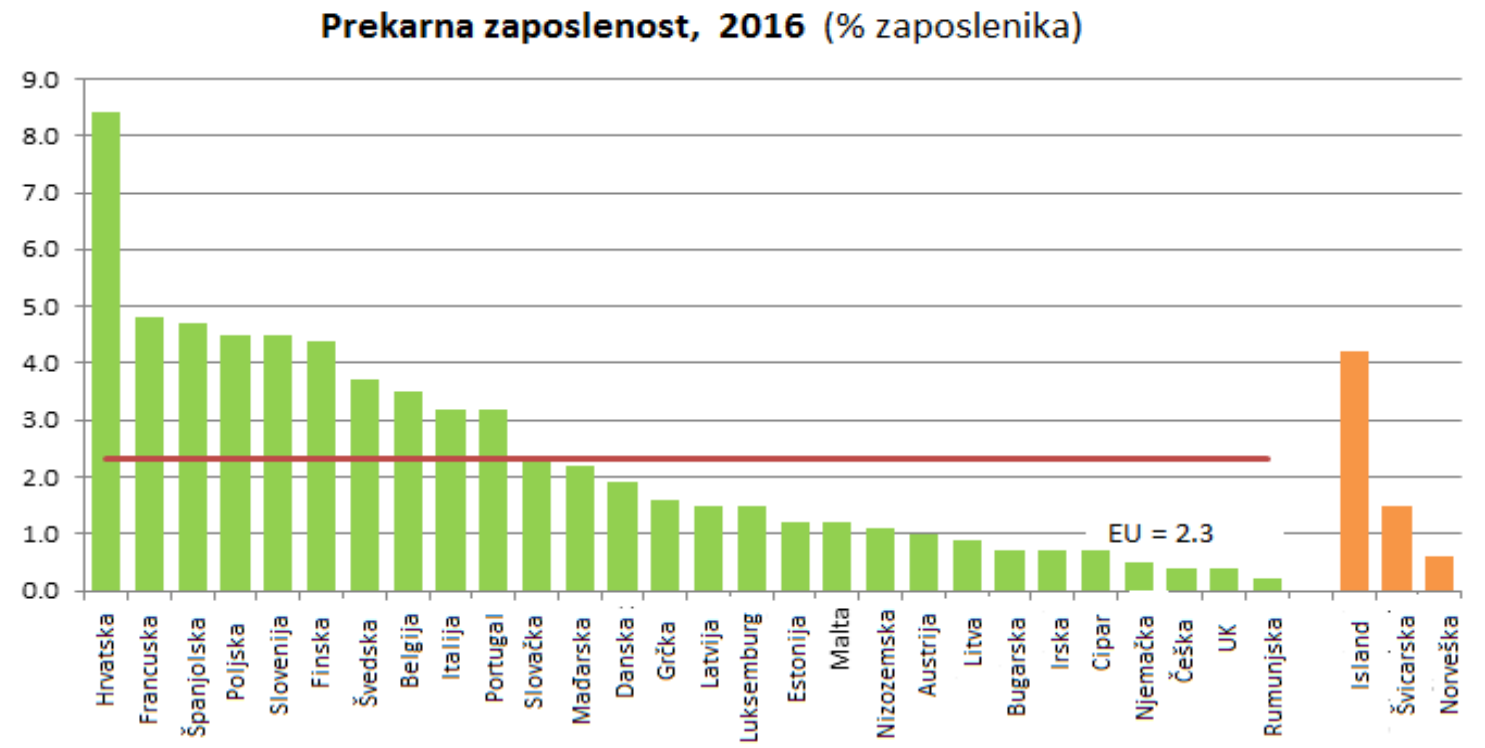

ec.europa.eu/eurostat?

Grafički prikaz 8.7 Prekarna zaposlenost (Eurostat, 2018)

Ispostavilo se da je u 2016. godini prekarna zaposlenost u Hrvatskoj bila na vrhuncu i da je u sljedeće dvije godine ipak nešto smanjena, i to na 7.1 posto u 2017. godini, a zatim na 6.9 posto u 2018. godini (Tablica 8.6). Iako posljednjih par godina bilježi pad udjela ugovora o radu na 
određeno u trajanju od 3 mjeseca, udio od 7 posto prekarne zaposlenosti još uvijek svrstava Hrvatsku u zemlje s iznimno visokim udjelom nesigurnih, fleksibilnih poslova, kada se uzme u obzir da se prosjek Europske unije kreće na tek oko 2 posto. Vjerojatno je da je porastu udjela prekarnih oblika rada u Hrvatskoj pridonijelo zapošljavanje u turizmu, kao i sve brojnije agencije za privremeno zapošljavanje, ali vjerojatno i neka vrsta zloupotrebe ugovora na određeno vrijeme od poslodavaca, koji taj institut koriste i u slučajevima kada je moguće s radnicima sklopiti ugovor na neodređeno vrijeme.

\section{Rad s nepunim radnim vremenom}

Jedan od oblika fleksibilnog radnog vremena je i rad s nepunim radnim vremenom. Rad s nepunim radnim vremenom Jasminka Kulušić (2009: 64) definira kao rad koji se odnosi na „radnike čije normalno radno vrijeme, izračunato na tjednoj osnovi ili prosjeku tijekom razdoblja zaposlenja do jedne godine, iznosi manje od normalnog radnog vremena zaposlenog na puno radno vrijeme, na usporedivom radnom mjestu.“ Radno pravo Europske unije prema Direktivi o radu s nepunim radnim vremenom, nastoji osigurati jednak tretman zaposlenih u nepunom radnom vremenu sa zaposlenicima $\mathrm{u}$ punom radnom vremenu, to jest provoditi zabranu bilo kakve diskriminacije radnika s nepunim radnim vremenom. Zaštita radnika $\mathrm{s}$ nepunim radnim vremenom upravljena je prema podizanju kvalitete rada određenog ugovor o radu na nepuno radno vrijeme, kao i način da se olakša i razvije taj oblik rada. Kulušić (2009) navodi da je spomenuta Direktiva Europske unije usmjerena na promicanje ovakve vrste fleksibilnosti, pri čemu se ističe preporuka Direktive kojom se države članice i socijalne partnere potiče da uklone prepreke ovom načinu zapošljavanja, kao i da zaštite radnike. Naime, savjetuje se da države članice provedu mjere zaštite radnika u slučajevima kada poslodavac radniku s punim radnim vremenom ponudi odnos na nepuno radno vrijeme. Odbijanje ponude u tom slučaju ne smije biti valjan razlog za otkazivanje ugovora o radu radnika na inicijativu poslodavca. Kulušić (2009) također navodi da je prema Direktivi Europske unije moguće uspostaviti radni odnos u nepunom radnom vremenu u kojem bi radnik imao različit tretman od radnika u punom radnom vremenu ako za to postoje objektivni razlozi i to na način da se primjenjuje načelo pro rata temporis. Naime, u načelu se radnicima u nepunom radnom vremenu isplaćuje plaća razmjerno radnim satima koje obavljaju i to u usporedbi s radnikom s punim radnim vremenom kod istog poslodavca, dok sva ostala prava iz radnog odnosa kao što su visina otpremnine, trajanje godišnjeg odmora, trajanje otkaznog roka jednako je usporedivom radniku s puni radnim vremenom. 
Prema hrvatskom radnom zakonodavstvu, u Hrvatskoj je i prije izmjena radno zakonodavnog okvira 2014. godine, bilo je moguće sklapati ugovore o radu u nepunom radnom vremenu, što se smatralo fleksibilnim oblikom rada. Prethodni je Zakon o radu uređivao radni odnos u nepunom radnom vremenu tako što je načelo pro rata temporis bilo primjenjivano samo na iznos plaće, dok su ostala prava radnika bila ista kao i kod usporedivog radnika. Kulušić (2009) je u odredbi stavka 2, članka 39. prethodnog Zakona o radu koji određuje da su u ostvarivanju prava iz radnog odnosa, rad u nepunom radnom vremenu tretira kao rad u punom radnom vremenu. Prema njezinim procjenama je to razlog zašto poslodavci procjenjuju da im zapošljavanje radnika u nepunom radnom vremenu predstavlja preveliki trošak. U novom Zakonu o radu iz 2014. godine prošireno je načelo pro rata temporis na način da se primjenjuje i na druga materijalna prava iz radnog odnosa, pa su jubilarne nagrade, regres i božićnice obračunavaju kao i plaća, proporcionalno odrađenim radnim satima, ako kolektivnim ugovorom, pravilnikom o radu ili ugovorom o radu nije drugačije uređeno. U tom je smislu došlo do smanjivanja prava radnika.

\subsubsection{Izmjene koje se odnose na proširenje mogućnosti fleksibilnosti radnog vremena}

Kao poseban oblika fleksibilnosti može se navesti i fleksibilnost radnog vremena, međutim, ona je povezana s numeričkom fleksibilnosti te se ponekad oblici fleksibilnosti radnog vremena i podvode pod numeričku fleksibilnost jer ona utječe na to hoće li poslodavac trebati više radnika za određeni posao ili će moći zadovoljiti povećanje potreba za radnom snagom s postojećim brojem radnika povećavajući radno opterećenje, odnosno nalažući radnicima prekovremeni rad. Na području fleksibilnosti radnog vremena, koja je za sindikate bila prijeporna pri posljednjim izmjenama Zakona o radu, došlo je do produljenja mogućnosti prekovremenog rada, izrađene su iznimke u kojima je moguće skratiti vrijeme dnevnog odmora između dvije smjene unutar 24 sata za radnike na sezonskim poslovima.

\section{Prekovremeni rad}

U novom se Zakonu o radu povećava broj prekovremenih sati koje radnik može odrađivati s prethodnih 8 tjedno, na u novom ZOR-u 10 sati tjedno. Važno je istaknuti da je u novom ZOR-u prekovremeni rad dopušten u slučajevima više sile, neočekivanog povećanja opsega poslova ili nekog drugog uzroka koji zahtijeva prijeku potrebu povećanja radnog kapaciteta kompanije. Dakle, za upotrebu instituta prekovremenog rada, poslodavac mora biti izložen nepredvidivim i izvanrednim okolnostima, što prekovremeni rad razlikuje od 
„redovnog“ prekovremenog rada koji se često pojavljuje u praksi kao mjera za kompenziranje kadrovskih manjkova, čime takozvani redovni prekovremeni rad priječi nova zapošljavanja (Kasunić Peris, 2014). Prema novom ZOR-u poslodavac je također dužan pisanim putem zatražiti od radnika prekovremeni rad prije samog početka prekovremenog rada. U slučajevima posebne hitnosti, moguće je da poslodavac i usmeno naloži radniku prekovremeni rad u slučaju hitne potrebe izvršavanja rada, premda u tom slučaju poslodavac treba u roku od sedam dana dostaviti radniku i pisanu potvrdu zahtjeva za prekovremenim radom.

\subsection{Drugi pokazatelji fleksibilnosti tržišta rada}

Promjene u zakonskoj regulativi odnosa na tržištu rada za vrijeme gospodarske krize u Hrvatskoj bile su dijelom motivirane i izvanjskim zahtjevima međunarodnih financijskih institucija kao što su Međunarodni monetarni fond te Svjetska banka sa svojim izvješćima o stanju različitih aspekata hrvatske ekonomije. Među tim izvješćima valja spomenuti i globalne ljestvice konkurentnosti, kao i primjerice OECD-ov ranije opisani EPL indeks. Što se tiče izvještaja Svjetske banke, ona redovito izdaje vlastito globalno izvješće o konkurentnosti gospodarstva zemalja pri čemu je jedan od čimbenika koje se navode kao integralne komponente cjelokupnog rezultata konkurentnosti i opće stanje na tržištu rada.

Politika na tržištu rada se sama sastoji od nekoliko čimbenika koji se mogu i mijenjati iz godine u godinu ovisno o promjenama u globalnom gospodarstvu. Valja primijetiti da su faktori koji daju određeni broj bodova nekoj državi za određeno područje gospodarstva, kao u ovom slučaju područje tržišta rada, odnosno politike tržišta rada, podložni značajnim promjenama. Zbog toga što se faktori koji utječu na ukupan rezultat države u smislu njezine konkurentnosti mogu gotovo proizvoljno mijenjati, valja postaviti pitanje je li uopće potrebno, ili pak mudro, krojiti politike neke države prema zahtjevima Svjetske banke, s obzirom na to da sve promjene koje se uvode, a usmjerene su na postizanje povoljnijeg mjesta na ljestvici konkurentnosti, ili se barem određene promjene mogu na taj način legitimirati, lako mogu promašiti postavljeni cilj. Osim što nadomještanjem nekoliko integralnih čimbenika koji čine indeks konkurentnosti zapravo dolazi do poništavanja učinka promjena politika u nekom području ukoliko je ono izbačeno kao čimbenik indeksa konkurentnosti, valja imati na umu da i druge zemlje rade na poboljšanju vlastite konkurentnosti, pa je, u tom duhu vječnog natjecanja na tržištu, stalne želje da se bude bolji i učinkovitiji od drugih, ta mjera izrazito relativna i ovisi o napretku, stagnaciji i nazadovanju drugih zemalja. Utoliko se može s pravom postaviti pitanje koliko su ljestvice konkurentnosti u funkciji gospodarskog i napretka, a koliko služe kao neka 
vrsta opravdanja za reforme, a najčešće je to u sklopu politika štednje, koje ne nailaze na odobravanje šire javnosti. 


\section{ZAKLJUČNA RASPRAVA}

U ovoj je doktorskoj disertaciji prikazano nastojanje da se kroz diskurzivnu analizu novinskih članaka o izmjenama Zakona o radu dođe do zaključaka o javnom diskursu o fleksibilizaciji tržišta rada i o njegovom interdiskurzivnom poretku. Cilj rada bio je opisati poredak diskursa koji tvore javni diskurs o fleksibilizaciji, s posebnim naglaskom na neoliberalnom diskursu te oponirajućim diskursima koji problematiziraju karakter i neoliberalnu interpretaciju fleksibilizacije tržišta rada. U radu se nastoji ustanoviti kako diskurs o fleksibilizaciji artikulira odnose moći društvenih aktera koji u njemu sudjeluju te povezati otkriveni poredak diskursa s javnim politikama na tržištu rada u Republici Hrvatskoj.

U prvom je dijelu rada opisana kritička analiza diskursa kao interdisciplinarni istraživački pristup proučavanju diskursa, njezin povijesni razvoj, znanstvenici koji su doprinijeli njezinoj popularizaciji i koji su je u metodološkom i teorijskom smislu razrađivali, poput Ruth Wodak i Normana Fairclougha te karakteristike koje ju čine prikladnom za proučavanje javnog diskursa o fleksibilizaciji tržišta rada. Kritička analizu diskursa usmjerena je na istraživanje društvenih problema nejednakosti u odnosima moći. Kritička analiza diskursa nije metoda, već istraživački pristup u kojem je prihvatljivo koristiti niz različitih teorijskih i metodoloških pristupa za koje istraživač procijeni da su učinkoviti u rasvjetljavanju relevantnih aspekata procesa društvenih promjena i procesa koje si zadaje kao predmet proučavanja. Kritička analiza diskursa usmjerena je na istraživanja koja se temelje na proučavanju konkretnih komunikacijskih događaja, bili to novinski članci, govori političara ili intervjui. Ti se komunikacijski događaji sastoje od lingvističkog i društvenog aspekta, odnosno oni predstavljaju korištenje jezika u različitim društvenim situacijama. Svi društveni fenomeni i procesi imaju svoju lingvističko-diskurzivnu dimenziju. Svaki je diskurs ujedno i oblik društvene akcije. Diskurs je oblik društvene prakse koja konstituira društvo i kulturu, ali je on ujedno i sam konstituiran. U kritičkoj analizi diskursa istaknuta je dijalektička povezanost između diskursa kao društvene prakse i drugih društvenih praksi. Sami diskurs sudjeluje u oblikovanju različitih društvenih praksi, ali on također i reflektira i razotkriva karakter društvenih praksi koje se zrcale u poredcima diskursa. U kritičkoj analizi diskursa ideologija se ostvaruje kroz diskurs. Kada proučavamo i istražujemo diskurs moramo biti svjesni toga da on nije neutralan već djeluje na način da podržava ili potiskuje određene konstelacije ideja čime doprinosi nejednakoj raspodjeli moći u društvu. Kritička analiza diskursa bavi se proučavanjem diskurzivnih praksi koje utemeljuju, održavaju i pobijaju određene ideologije održavajući odnose nejednakosti u društvu, kao i proučavanjem diskurzivnih praksi koje postavljaju izazove 
pred pretpostavljeni status quo u društvu i usmjeravaju društvo prema promjenama. Kao što je već navedeno, svaki je istraživač koji odabere kritičku analizu diskursa kao istraživački pristup koji će koristiti u istraživanju nekog društvenog problema pozvan da sam odredi metode koje će koristiti u nastojanju da na što bolji način istraži određenu problematiku, pa se tako i glavni predstavnici kritičke analize diskursa razlikuju u koncepciji i metodama analize. Za potrebe ovog rada, odabrana je Faircloughova koncepcija kritičke analize diskursa kao njezina metodološki možda najrazrađenija varijanta. Norman Fairclough opisao je koncept kritičke analize diskursa koji se sastoji od trodimenzionalnog modela pristupu materijalu analize, odnosno komunikacijskim događajima kao manifestacijama diskursa i poredaka diskursa. Prema njegovu konceptu, u ovom je radu problematici i materijalu istraživanja pristupljeno kroz trostruku analizu. Uzorak članaka iz dnevnih novina o temi fleksibilizacije tržišta rada analiziran je na tri razine. Prva razina odnosi se na neku vrstu kvalitativne analize tema, koja je pokazala koje teme prevladavaju u javnom diskursu o fleksibilizaciji tržišta rada. Druga se razina odnosi na interdiskurzivnu analizu ili analizu diskurzivnih praksi a predstavlja opisivanje javnog diskursa kao poretka diskursa koji se sastoji od različitih vrsta argumentacija koje upućuju na prisutnost različitih vrsta diskursa koji sačinjavaju javni diskurs o fleksibilizaciji tržišta rada. Među prisutnim diskursima osobito je važan neoliberalni diskurs kao izraz nastojanja političkih aktera da u javnosti promiču određeni oblik fleksibilizacije tržišta rada, zajedno s oponirajućim diskursima koji zajedno čine diskurs socijalne države. Treća se komponenta kritičke analize diskursa ovog istraživanja odnosi na analizu politika na tržištu rada koja predstavlja treću dimenziju Faircloughova modela, odnosno analizu društvene prakse.

Nakon opisa kritičke analize diskursa, za analizu diskursa bilo je važno u doktorskom radu opisati koncept neoliberalizma, neoliberalne ideologije, neoliberalnog identiteta i neoliberalnog diskursa. Neoliberalizam se pokazao kao teško odrediv pojam, pa je u radu bilo potrebno, osim pukog nizanja definicija neoliberalizma iz literature, ukratko obraditi i perspektive koje se njime bave, kontekst nastanka neoliberalne doktrine, kao i njezine značajke. Postoji barem sedam teorijskih perspektiva koje opisuju i definiraju neoliberalizam, u koje spadaju i Foucaultova perspektiva neoliberalnog governmentaliteta, ideacijska analiza i na primjer marksistička perspektiva. Svih sedam perspektiva je dominantno kritičke orijentacije. Iako naglašavaju različite aspekte neoliberalizma, navedene perspektive proizlaze iz sličnih pozicija, a u svojim se teorijskim konstrukcijama uvelike međusobno podupiru radovima istih teoretičara i njima svojstvenih konceptualizacija koje čine gradbene sastojke pojedinih teorijskih perspektiva. Iz tog razloga u radu nije prisutna predanost pojedinoj perspektivi pri 
konceptualizaciji identiteta neoliberalne doktrine, odnosno ideologije i njezine artikulacije u formi neoliberalnog diskursa s obzirom na to da se neoliberalizam, odnosno neoliberalizacija, konceptualizira na načine koji proistječu iz srodnih teorijskih pretpostavki i za koje se sve može reći da su utemeljene u nekoj varijanti kritičke teorije. Pri opisu neoliberalne ideologije, odnosno neoliberalne doktrine u najvećoj mjeri je uvažen teorijski doprinos Friedricha Hayeka neoliberalnom korpusu ideja. Neoliberalna je doktrina oblikovana izrastajući iz i unekoliko se razlikujući od klasičnog i neoklasičnog liberalizma. Morfologija koncepata doktrine neoliberalizma nastala je postavljajući u svoje središte koncepte slobodnog tržišta, privatnog vlasništva i pravne države po čemu se razlikovala od prijašnjih, odnosno ostalih pravaca liberalne misli. Neoliberalni politički identitet nastajao je i razvijao se određujući se kao suprotnost u odnosu na kejnzijansko/kvazisocijalističko Drugo. Fluidnost i protejski karakter neoliberalnog identiteta pokazuje se i u dva naličja neoliberalnog diskursa. Prvi je transparentni neoliberalni diskurs, koji se može poistovjetiti s diskursom britanske premijerke Margaret Thatcher i koji je u svom izričaju otvoreno neprijateljski prema organiziranom radu i socijalnoj državi. Drugi je diskurs „trećeg puta“ ili diskurs premijera Tonyja Blaira koji se služi ublaženom retorikom $\mathrm{u}$ promicanju primata slobodnog tržišta nad socijalnim aspektima državnog djelovanja i naziva se eufemiziranim diskursom. Ova distinkcija će se pokazati korisnom u samoj analizi diskursa o fleksibilizaciji tržišta rada u Hrvatskoj.

Na temeljima spomenutih opisa i distinkcija neoliberalne ideologije i neoliberalnog identiteta pristupilo se i analizi neoliberalnog pristupa tržištu rada pri čemu je ustanovljeno nekoliko karakterističnih neoliberalnih perspektiva koja su važna u proučavanju diskursa o fleksibilizaciji tržišta rada. Jedna od tih perspektiva odnosi se i na originalan doprinos neoliberalnoj misli teoretičara Garyja Beckera o ljudskom kapitalu kao osebujnom pogledu na radnu snagu na tržištu rada. Kroz teoriju o ljudskom kapitalu, neoliberalna je misao zakoračila u dotad neistraženi teritorij i omogućila naknadni razvoj teorije ljudskih resursa u menadžmentu poduzeća. Ova je teorija izmijenila relacije odgovornosti na tržištu rada i fleksibilizaciju na tržištu rada okarakterizirala kao oslobođenje radnika, a ne smanjivanje njihovih prava i snižavanje cijene rada, i to prebacivanjem odgovornosti za obrazovanje, obuku, odnosno za nezaposlenost s države i poslodavca na pojedinačnog radnika. Druga značajna neoliberalna perspektiva u sklopu neoliberalnog pogleda na tržište rada odnosi se na neoliberalnu, blago rečeno nenaklonost organiziranom radu, koju je u svojim teoretiziranjima osobito gorljivo promicao sam Friedrich Hayek. 
Kao što je već ranije navedeno, diskurzivnim se pristupom nastojalo dati odgovore na pitanja o provedbi posljednje reforme tržišta rada u Hrvatskoj u smjeru njezine fleksibilizacije i u kolikoj je mjeri javni diskurs o fleksibilizaciji tržišta rada bio konstituiran interesima koji su se legitimirali kroz neoliberalno viđenje same fleksibilizacije primjenom ranije opisanih spoznaja o neoliberalnom diskursu općenito, ali i o neoliberalnom diskursu u odnosu na samu fleksibilizaciju.

Analizom materijala novinskih članaka koji su se izravno ili neizravno odnosili na temu izmjena Zakona o radu i fleksibilizacije tržišta rada ustanovljene su najčešće teme koje se povezuju sa spomenutim pojmovima kao i akteri koji u najvećoj mjeri sudjeluju u javnom diskursu o fleksibilizaciji tržišta rada. Uzorak je pri analizi podijeljen na dva dijela. Prvi se dio odnosio na razdoblje do donošenja izmjena Zakona o radu prije pristupanja Europskoj Uniji i koji je predstavljao izmjene koje su bile nužne radi usklađivanja hrvatskog zakonodavstva s acquis communautaireom. Za razliku od drugih zemalja istočne Europe poput Poljske ili Slovačke, u kojima je spomenuto usklađivanje iskorišteno od stranih ulagača i domaćih poslodavaca za značajne fleksibilizacije tamošnjih tržišta rada, u Hrvatskoj su određeni aspekti fleksibilizacije odgođeni, tako da se, unatoč negodovanju pravnih stručnjaka, promjenama radnog zakonodavstvu pristupalo u dva dijela. Proces izmjena podijeljen je na dva dijela vjerojatno zbog potrebe ubrzavanja usklađivanja prije pristupanja Europskoj uniji jer su tadašnja Vlada i ministar rada procijenili da se veće izmjene Zakona neće moći na vrijeme ispregovarati s industrijskim akterima. Prvi je dio promjena sadržavao i neke prednosti za same radnike, pa su i neke promjene u smjeru fleksibilizacije koje su podrazumijevale smanjivanje prava radnika, kao na primjer one koje su se odnosile na ugovore na određeno ili radno vrijeme u sezonskim poslovima, bile prihvaćene $u$ javnosti bez značajnijih otpora koji bi dolazili od sindikata ili javnosti. U uzorku koji je obuhvaćao vrijeme od 1. 1. 2013. godine do 15. 6. 2013., odnosno do donošenja izmjena Zakona o radu prije pristupanja Europskoj uniji sadržano je 22 posto svih članaka u uzorku, dok je drugi dio koji se odnosio na donošenje potpuno novog, izmijenjenog Zakona o radu, javni diskurs o fleksibilizaciji promatran u razdoblju od 16. 6 . 2013. godine do 15. 7. 2014. godine sadržavao je 78 posto ukupnog broja analiziranih članaka. Iako je drugo razdoblje bilo dvostruko dulje, tijekom tog razdoblja objavljeno je gotovo za jednu trećinu više članaka koji su se doticali teme fleksibilizacije tržišta rada što govori u prilog tome da je u drugom razdoblju, tijekom kojeg se pregovaralo o značajnijim reformama u smjeru fleksibilizacije, tema fleksibilizacije imala značajnije mjesto u javnom diskursu. Tekstove je u datim razdobljima analize bilo moguće raspodijeliti prema šest osnovnih tema. U uzorku su 
najbrojniji članci koji se bave temama reformi i ulaganja u kojima su glavni akteri poslodavci i strani i domaći ulagači, a nakon njih slijede teme vezane uz tripartitni dijalog, zatim različiti osvrti na promjene koje se donose u Zakonu o radu, prekid tripartitnog dijaloga i pregovora o izmjenama Zakona o radu, a u manjoj mjeri su tu i teme vezane uz izvještaje o nezaposlenosti te članci koji kritiziraju tada aktualne mjere štednje.

U samoj tematskoj strukturi članaka u uzorku vidljiva je određena razina dominacije tema stranih ulaganja koje su u tekstovima uvjetovane reformama koje podrazumijevaju mjere štednje, a koje promiču poslodavci i ulagači kao zainteresirani akteri u javnom diskursu. U spomenutim se člancima kao zahtjevi za promjenama u radnom zakonodavstvu, a u smjeru smanjivanja troškova rada predlagane mjere olakšavanja otkaza i općenitog smanjivanja poreza i troškova rada. Zato u temama koje se tiču poslodavaca, najveću težinu imaju promjene koje bi išle u smjeru jačanja numeričke fleksibilnosti pa je tako promišljanje o olakšavanju otkaza jedna je od najvažnijih tema koje se pojavljuju u analiziranom korpusu. Olakšavanje otkaza i smanjenje troškova otkaza prioritetno je područje liberalizacije tržišta rada za poslodavce, bez obzira na to radilo se o većim kompanijama, ili malim i srednjim poduzetnicima zbog kojih su predstavnici poslodavaca tražili da se u Zakon o radu ugradi odredba koja bi za male poslodavce omogućila potpunu liberalizacija otkaza, odnosno mogućnost davanja otkaza bez objašnjenja. Iako se na koncu takva ekstremna liberalizacija nije dogodila i to ne zbog otpora javnosti pa čak niti sindikata, čiji su čelnici najvećim dijelom pristali na tu promjenu, osim sindikalnog čelnika Krešimira Severa, prepreka ostvarenju te izmjene na koncu je bio europski zakonodavni okvir koji onemogućava uvođenje mogućnosti otkaza bez objašnjenja jer se njime radniku koji je na taj način otpušten onemogućuje jednako pravo pristupa sudu.

Drugi prijedlozi izmjena radnog zakonodavstva također su bili usmjereni na snižavanje troškova potencijalnog smanjivanja broja radnika u poduzećima ili javnom sektoru. Prema prijedlogu Vlade trebalo je doći do smanjivanja visine otpremnina, a kao kompenzacija radnicima predloženo je povećanje naknade za nezaposlenost. Ministar rada i mirovinskog sustava također je predlagao osnivanje fonda za otpremnine po uzoru na austrijski model, u koji bi poslodavci za radnike mjesečno uplaćivali određeni iznos, koji bi se radniku isplaćivao u slučaju otkaza. Poslodavci su ovi promjenu vidjeli kao trošak zbog predloženog modela osnivanja fonda u koji su poslodavci trebali uplaćivati određen iznos na račun radnika pa nisu podržavali tu promjenu. Drugi aspekt fleksibilizacije tržišta rada koji možemo povezati s numeričkom fleksibilnošću tiče se ugovora na određeno, koji poslodavcu olakšava smanjivanje zaposlenika, odnosno facilitira fleksibilniju raspodjelu radne snage na kraći rok jer ga oslobađa dugoročnih financijskih obaveza prema radniku. Kao način zaobilaženja trošenja financijskih i 
vremenskih resursa poslodavaca na otkaze radnicima, $\mathrm{u}$ javnom je diskursu također bilo istaknuto traženje određenih aktera, osobito samih postojećih agencija za privremeno zapošljavanje, liberalizacije djelovanja i poslovanja agencija za privremeno zapošljavanje. Kada je riječ o temama koje se odnose na zahtjeve o fleksibilizaciji rada, onda poslodavci i (strani) ulagači dominiraju u tom dijelu javnog diskursa, gdje u temama kao što su strana ulaganja kontinuirano ističu potrebu reformi u Hrvatskoj koja je uvijek na tragu politika štednji u javnom i državnom sektoru, pa se tu ističu zahtjevi za smanjivanjem poreza, „državnih nameta“, troškova rada i općenito troškova koje predstavlja državna administracija ukazujući na „nabujalost“ državnog aparata implicirajući potrebu smanjivanja broja zaposlenih u javnom sektoru.

Sindikati kao akteri u javnom diskursu o fleksibilizaciji tržišta rada najznačajnije su zastupljeni u drugom razdoblju donošenja potpuno novog Zakona o radu kada su zbog neslaganja s drugim industrijskim akterima u tripartitnom dijalogu napustili pregovore o novom Zakonu o radu. Nakon prekida pregovora sindikati počinju organizirati referendum o štrajku pa i pripreme za sam štrajk ukoliko se ne ispune njihovi uvjeti. Važno je istaknuti da sindikati, vjerojatno zbog jednostavnijeg prezentiranja svoje uloge u procesu izmjena Zakona, inzistiraju samo na tome da Vlada odustane od predloženih promjena koje je planirala u radnom zakonodavstvu, međutim tek je ponegdje u javnom diskursu prisutno detaljnije obrazloženje argumentiranih razloga za odupiranje sindikata. U diskursu o organiziranju štrajka uvijek je naglašeno odmjeravanje snage sindikata u odnosu na Vladu ili poslodavce, a manje se ističu konkretni razlozi zbog kojih predlagana razina fleksibilizacije tržišta rada nije prihvatljiva.

Značajan je dio članaka posvećen temama koje se pretežno odnose na zahtjeve poslodavaca, a mnogi se njihovi zahtjevi, odnosno većina njih, odnosila na traženje povećanja numeričke fleksibilnosti i fleksibilnosti radnog vremena. U javnom se diskursu prepoznaje da se tadašnja Vlada republike Hrvatske najviše, doduše posredno i to preko teme otpremnina, usredotočila na mogućnost smanjivanja plaća kao i na olakšavanje otkaza u javnim i državnim službama. Sindikati se značajnije probijaju u prostor javnog diskursa tek organizacijom referenduma o generalnom štrajku, međutim, u javnom diskursu nisu prisutni argumenti za traženje snažnijih zaštita postojećih prava ili ostvarivanje novih prava radnika, već su to u najvećem dijelu kritike protiv aktualne vlasti, ali i reakcije na kritike samih predstavnika poslodavaca.

Kod otkrivanja i opisivanja poretka diskursa u javnom diskursu, tekstovima se pristupilo utvrđujući načine na koje pojedini akteri pristupaju određenim aspektima fleksibilizacije tržišta 
rada, bilo da se radilo o pristupu s pozitivnim ili negativnim predznakom u odnosu na samu fleksibilizaciju. S obzirom na ustanovljene karakteristike neoliberalnog diskursa o fleksibilizaciji tržišta rada s kod njega već ustanovljenim argumentacijama koje govore u prilog fleksibilizaciji koja pogoduje snižavanju troškova poslodavaca očekivano je da je u javnom diskursu neoliberalni diskurs bio zastupan najvećim dijelom od kapitala, odnosno ulagača i poslodavaca.

Prva argumentacija za kojom se poseže pri nastojanjima da se u javnosti proces fleksibilizacije prikaže pozitivnim jest percepcija „fleksibilnosti tržišta rada kao načina da se povećaju ulaganja podizanjem konkurentnosti”; a u radu je skraćeno nazvana ,argumentacijom konkurentnosti”. U javnom diskursu o fleksibilizaciji tržišta rada, prisutna je argumentacija da je fleksibilizacija tržišta rada kroz deregulaciju radnih zaštita jedan od nekoliko ključnih čimbenika koje određuju konkurentnost gospodarstva neke države. Argumentacija konkurentnosti predstavlja retoriku slobodnog tržišta koja pripada (transparentnom) neoliberalnom diskursu. Transparentni neoliberalni diskurs pretpostavlja da bi se odnosi na tržištu rada trebali uređivati na način da se omoguće uvjeti tržišnog natjecanja otklanjanjem zakonske regulacije koja utječe na tržišno natjecanje. Transparentni neoliberalni diskurs najvećim se dijelom prepoznaje pojavljivanjem pojma „konkurentnosti”, odnosno „kompetitivnosti” koji se kada je riječ o supojavljivanju različitih pojmova s pojmom Zakona o radu ili pojmom fleksibilizacije u pojedinačnim jedinicama analize, odnosno pojedinačnim tekstovima kao komunikacijskim događajima značajno supojavljuje.

Druga se vrsta argumentacija sastoji od toga da zagovaratelji fleksibilizacije i predlagatelj Zakona o radu kojim bi se trebala omogućiti fleksibilnost na tržištu rada, ističu da je navedeni proces smanjivanja zakonske zaštite radnika potreban, a kao razlog navode da regulacija tržišta rada otežava ili onemogućuje restrukturiranje privatnih poduzeća, odnosno provođenje strukturnih reformi državnih i javnih službi te državnih poduzeća. Fleksibilnost tržišta rada, odnosno deregulacija radnih odnosa shvaćena je kao instrument u rukama zakonodavca kojim se omogućuje racionalizacija troškova poduzeća, odnosno državna politika štednje. „Argumentacija restrukturiranja” ponajprije se odnosi na aspekt numeričke fleksibilnosti, to jest na omogućavanje poslodavcima da lakše daju otkaze, pa su ključne riječi koje se odnose na navedeni tip argumenta „restrukturiranje tvrtki”, „strukturne reforme”, „otkaz”, „,bolni rezovi”, ,potrošnja države” i slično.

Treći skup argumenata kojim se u javnosti nastoji legitimirat fleksibilizacija odnosi se na tvrdnju da je deregulacija tržišta rada pozitivna za same radnike jer povećava njihovu 
slobodu i proširuje mogućnosti izbora poslova koji su na tržištu rada dani kao mogućnost. Treći skup argumenata možemo nazvati ,argumentacijom individualne odgovornosti”, a ključni pojmovi koji najčešće upućuju na prisutnost navedene argumentacije u analiziranim tekstovima jesu „,cjeloživotno učenje“, ,prilagodljivost“, „,mobilnost“”, ,produktivnost“, ,,sloboda radnika“, „mogućnost veće zarade”. Prema zagovornicima deregulacije tržišta rada, fleksibilnost koristi radnicima jer omogućuje povećanje vrijednosti njihova rada, poticanjem razvoja ljudskog kapitala. Ova argumentacija sadrži pretpostavku da će deregulacija tržišta rada i uvođenje veće fleksibilnosti u radne odnose poticati radnike da budu mobilni i prilagodljivi, čime se podrazumijeva da je to korisno samim radnicima, iako pojam ljudskog kapitala zapravo predstavlja naglašavanje karakteristika radnika u skladu s potrebama kapitala odnosno prema onome što je korisno samim poslodavcima.

Četvrta se vrsta argumentacije odnosi na zagovaranje fleksibilizacije tržišta rada kao oblika suvremene i neizbježne organizacije radnih odnosa pretpostavljajući da bi ta promjena označavala modernizaciju radnih odnosa i nastavak procesa tranzicije Hrvatske u moderno kapitalističko društvo, odnosno ,argumentacija modernizacije”. Kod argumentacije modernizacije karakteristično je suprotstavljanje postojećeg Zakona o radu kao zastarjelog u odnosu na novopredloženi Zakon koji pak predstavlja kretanje odnosa na tržištu rada ukorak s vremenom. Stari je Zakon o radu u javnom diskursu o fleksibilizaciji označen kao „rigidan” i „neprilagođen” duhu vremena, a tržište rada je, kao rezultat njegove primjene, postalo „zamrlo” ili „umrtvljeno”. Predloženi, izmijenjeni Zakon o radu opisuje se kao „moderan” i „liberalan” zakon koji bi trebao riješiti mnoge probleme na tržištu rada te bi prvenstveno postao usklađen sa zahtjevima suvremenog ekonomskog sustava utemeljenog na konkurentnosti i globalnim tržištima, ali i zahtjevima novih tehnologija i proširenja sektora usluga i njegova udjela u stvaranju radnih mjesta na tržištu.

Skupine argumenata u javnom diskursu prema kojima fleksibilnost ima pozitivan učinak na tržište rada tvrdeći da je regulacija tržišta rada ta koja uzrokuje visoku nezaposlenost i nisku zaposlenost u analizi je označena kao ,argumentacija rješavanja problema nezaposlenosti“،. Ona se odnosi na zagovaranje fleksibilizacije tržišta rada zbog pretpostavke da u prevelikoj mjeri regulirana tržišta rada u uvjetima globalne ekonomije karakterizira visoka stopa nezaposlenosti, odnosno niska stopa zaposlenosti te segmentacija tržišta rada. Prema navedenoj skupini argumenata, ostvarivanje fleksibilnosti radnih odnosa koje se provodi deregulacijom tržišta rada omogućuje otvaranje novih radnih mjesta i zadržavanje postojećih te na taj način pozitivno djeluje na povećanje broja zaposlenih. U kontekstu argumentacije 
povezane s nezaposlenošću, kolokacije koje ukazuju na prisutnost navedene argumentacije jesu „radna mjesta”, „prepreke zapošljavanju”, „mladi i visokoobrazovani”, „,nezaposleni”, ,privremeni rad”, ,segmentacija“.

U javnom diskursu također se pojavljuje argumentacija koja se ne odnosi toliko na neku tvrdnju kojom bi se u ekonomskom smislu opravdalo provođenje fleksibilizacije deregulacijom fleksibilizacija tržišta rada, već je fleksibilizacija shvaćena kao dio politika koje su važne za postizanje ciljeva koji su zajednički interes čitave zemlje; to jest zajednički i poslodavcima i radnicima. Dapače, u javnom diskursu u kontekstu spomenute argumentacije prisutno je inzistiranje da fleksibilizacija tržišta rada zahtijeva široki konsenzus svih dijelova društva jer je ona dio nacionalnog interesa. U središtu navedene argumentacije naglasak je na jedinstvu zajedničkog interesa, odnosno potrebe postizanja nacionalnog konsenzusa poslodavaca i radnika, a time i čitavog hrvatskog društva, pa je za fleksibilizaciju ključno održavati tripartitni, odnosno socijalni dijalog čime se postiže konsenzus između (socijalnih) partnera o provođenju fleksibilizacije tržišta rada deregulacijom. Argumentacija zajedničkog nacionalnog interesa traži konsenzus svih članova društva oko predloženih mjera fleksibilizacije koje bi trebale proizvesti određene učinke koji su u diskursu ocijenjeni kao poželjni i pozitivni, a to su na primjer privlačenje stranih ulaganja, smanjivanje nezaposlenosti, poticanje radnika na cjeloživotno učenje u svrhu ulaganja u ljudski kapital, a time i ,jačanje” konkurentnosti radnika na tržištu rada.

U tekstovima je prisutno i naličje argumentacije nacionalnog konsenzusa, a odnosi se na argumentaciju koja ima drugačiju perspektivu na odnos između radnika i poslodavaca. Argumentacija nacionalnog interesa temelji se na pretpostavci da je ono što je dobro za poslodavce dobro i za radnike, ali i društvo u cjelini te da između radnika i poslodavaca nema pravog sukoba interesa. Argumentacija koja upravo u suprotnosti s prethodnim tvrdnjama o jedinstvu interesa stavlja naglasak na sukob interesa između poslodavaca i radnika može se nazvati „,argumentacijom sukoba interesa između poslodavaca i radnika“. Akteri koji se služe spomenutom argumentacijom drže da ukoliko se zahtijevaju ustupci jedne strane, odnosno radnika, u smjeru fleksibilizacije, onda to valja popratiti ustupcima koji podrazumijevaju odricanje od određenih interesa na drugoj strani, odnosno na strani poslodavaca. Ova argumentacija je u najvećoj mjeri zagovarana od predstavnika sindikata.

„Argumentacijom o nesigurnosti radnika na fleksibilnom tržištu rada“ u javnom se diskursu ukazuje se na to da je poslodavac u odnosu na radnika u moćnijoj poziciji na tržištu rada, ukoliko zaštitu radnika ne osiguravaju institucije tržišta rada reguliranog radnim 
zakonodavstvom, ali i članstvo u sindikatima. Bez adekvatnih zaštita i garancija na tržištu rada, radnik je izložen tržišnim mehanizmima koje poslodavac zbog svoje jače pozicije može okretati u vlastitu korist i to ponajprije snižavanjem cijene rada, a posljedično čak i iskorištavanjem radnika, što može rezultirati porastom socijalnih nejednakosti. Ključne jedinice značenja koje upućuju na argumentaciju slabije pozicije radnika u javnom diskursu sastoje se od sintagmi „rušenje cijene rada”, „nesigurnost”, ,iskorištavanje” i slično.

„Argumentaciju politike potrošnje“ čine tvrdnje koje se temelje na kejnzijanskoj ekonomici kao načinu kreiranja ekonomskih politika, u koje se između ostalog ubrajaju i politike na tržištu rada. Argumentacija politike potrošnje predstavlja oponirajući moment u javnom diskursu koji se suprotstavlja neoliberalnom zagovaranju politike štednje i restrukturiranja kao odgovora na gospodarsku krizu, ali i krizu na tržištu rada. Nasuprot neoliberalnim načelima poduprijete politike štednje, zagovornici kejnzijanizma i socijalne države traže ekonomski rast utemeljen na poticanju potrošnje, pri čemu je naglasak na smanjivanju socijalnih nejednakosti, većim pravima i zaštiti radnika te labavijoj fiskalnoj, pa čak i monetarnoj politici. U kontekstu javnog diskursa o fleksibilizaciji tržišta rada, nalazimo tvrdnje da fleksibilizacija tržišta rada, osobito aspekti koji se odnose na olakšavanje otpuštanja radnika i restrukturiranje, neće proizvesti željene ekonomske ili socijalne učinke, već je za smanjivanje nezaposlenosti i ekonomski napredak potrebno raditi na povećanju potrošnje. Ključna riječ koja ukazuje na argumentaciju politike potrošnje u diskursu o fleksibilizaciji tržišta rada jest „poticanje potrošnje“ ili pak „socijalna država“ te „kejnzijanizam“.

Prema prethodnoj analizi diskurzivnih praksi o fleksibilizaciji tržišta rada, pojedine argumentacije moguće je smjestiti u općenitije diskurse koji se onda mogu postaviti u relacije s neoliberalnim diskursom kao i s njemu oponirajućim diskursima socijalne države. Iz analize argumentacija prisutnih u javnom diskursu zaključujemo da kada se radi o javnom diskursu o fleksibilizaciji tržišta rada, onda je taj poredak diskursa možda najjednostavnije shvatiti kao neku vrstu kontinuuma koji se proteže od argumentacija koje zagovaraju otvoreno „tvrdolinijski“" neoliberalni diskurs s njegovim naglaskom na općem širenju slobodnog tržišta i zagovaranju smanjivanja zaštita radnika kako u privatnom, tako i u javnom sektoru do diskursa socijalne države koji stoji na drugoj stani spektra i koji je zbog izrazito malog broja pripadajućih mu argumentacija prisutnih u javnom diskursu vrlo slaba oponirajuća snaga neoliberalnim diskursima. Ako polazimo od transparentnog neoliberalnog diskursa koji se u radu naziva „neoliberalni diskurs konkurentnosti“, u koji spadaju argumentacija konkurentnosti, argument restrukturiranja, i argument ljudskog kapitala ili individualne odgovornosti, sljedeći po redu s 
nešto blažim pogledom na fleksibilizaciju tržišta rada jest eufemizirani neoliberalni diskurs koji sadrži argumentaciju modernizacije radnog zakonodavstva i tržišta rada kao i argumentaciju o fleksibilnosti kao rješenju nezaposlenosti na tržištu rada. „Diskurs socijalnog partnerstva“ dijelom se može okarakterizirati kao eufemizirani neoliberalni diskurs, a dijelom kao diskurs blizak diskursu socijalne države i u njemu se sastaju argumentacija nacionalnog konsenzusa ili argumentacija zajedničkih interesa rada i kapitala te argumentacija socijalnog kompromisa, odnosno argument različitosti interesa rada i kapitala. Naposljetku, vrlo slabo zastupljen diskurs socijalne države u koji spadaju argumenti poput onog koji se odnosi na nesigurnost na tržištu rada, rast socijalne nejednakosti i zagovaranje politike javne potrošnje.

U pogledu sudjelovanja industrijskih i drugih zainteresiranih aktera u javnom diskursu zastupanjem određenih argumentacija karakterističnih za neki od navedenih diskursa, nema prevelikih iznenađenja u pogledu toga što koji zainteresirani akter zastupa, pa je diskurs poslodavaca i poduzetnika, odnosno ulagača najvećim dijelom neoliberalan, bilo na transparentan ili eufemizirani način, sindikati u svojim argumentacijama naginju diskursu socijalne države zajedno s naglašavanjem diskursa o suprotnosti interesa radnika i poslodavaca što poprima oznake konfliktnog diskursa. Država ili Vlada pretežno se koristi argumentima koji se mogu svrstati u eufemizirani neoliberalni diskurs, s povremenim iskazima koji pripadaju transparentnom neoliberalnom diskursu ili pak u kritici poslodavaca ponekad i diskursu socijalne države.

U posljednjem dijelu koji se odnosi na treću dimenziju Faircloughova trodimenzionalnog modela, odnosno na javne politike na tržištu rada, analiza se usredotočila na promjene u Zakonu o radu pri čemu se posebna pozornost obraćala promjenama koje su prethodno u javnom diskursu predlagane od različitih zainteresiranih aktera. Analiza se također sastojala od pregleda dostupnih podataka o trendovima na tržištu rada Hrvatskog zavoda za zapošljavanje, Eurostata i Ministarstva rada i mirovinskog sustava, koji pokazuju da je došlo do znatne fleksibilizacije hrvatskog tržišta rada i porasta prekarnog rada i to najvećim dijelom zbog promjena u zapošljavanju na određeno vrijeme i promjena u regulaciji agencija za privremeno zapošljavanje. Pokazatelji fleksibilnosti tržišta rada upućuju na značajan utjecaj reforme tržišta rada oblikovane zahtjevima artikuliranima u javnom diskursu na fleksibilnost tržišta rada u Hrvatskoj. 


\section{LITERATURA}

*** (2011) „Mjesečni statistički bilten“, Hrvatski zavod za zapošljavanje, No. 1-12

*** (2012) „Mjesečni statistički bilten“, Hrvatski zavod za zapošljavanje, No. 1-12

*** (2013) „Mjesečni statistički bilten“, Hrvatski zavod za zapošljavanje, No. 1-12

*** (2014) „Mjesečni statistički bilten“, Hrvatski zavod za zapošljavanje, No. 1-12

*** (2015) „Mjesečni statistički bilten“, Hrvatski zavod za zapošljavanje, No. 1-12

*** (2016) „Mjesečni statistički bilten“, Hrvatski zavod za zapošljavanje, No. 1-12

*** (2017) „Mjesečni statistički bilten“, Hrvatski zavod za zapošljavanje, No. 1-12

*** (2017) ,Zakon o radu“ Narodne novine 93/14, 127/17

*** (2019) „Zakon o mirovinskom osiguranju“ Narodne novine 157/13, 151/14, 33/15, 93/15, $120 / 16,18 / 18,62 / 18,115 / 18$

*** (2019) ,Zakon o tržištu rada“ Narodne novine 118/18

*** (2019) ,Zakon o doprinosima“ Narodne novine 84/08, 152/08, 94/09, 18/11, 22/12, $144 / 12,148 / 13,41 / 14,143 / 14,115 / 16,106 / 18$

*** (2019) „Izvješće o agencijskom radu za 2018. godinu“, Ministarstvo rada i mirovinskog sustava, http://www.mrms.hr/wp-content/uploads/2019/03/IZVJEŠĆE-O-AGENCIJSKOMRADU-ZA-2018..pdf [pristupljeno 3. 9. 2019.]

*** (2019) „Labour market statistics“, Eurostat, https://ec.europa.eu/eurostat/web/labourmarket/publications [pristupljeno 21. 5. 2019.]

Argandona, A. (2001). „The Social Dimensions of Labour Market Institutions.“ U: The Social Dimensions of Employment: Institutional Reforms in Labor Markets, Jordi Gual i Antonio Argandona. (ur.), Cheltenham, Brookfield: Edward Elgar Publishing,

Auer, P. (2007). „Security in labour markets: Combining flexibility with security for decent work." Geneva: International Labour Organization

Bagić, D. (2010). Sustav industrijskih odnosa u Republici Hrvatskoj: hrvatski sindikati između društvene integracije i tržišnog sukoba. Doktorska disertacija.

Bejaković, P. (et. al.). (2014). Zakon o radu s komentarima i tumačenjima. Zagreb: Tim Press

Bilić, A. (2009). „Fleksibilni oblici rada i radno pravo.“ Zb. Prav. fak. Sveuč. Rij. (1991), 30(2), 920-942

Birch, K. (2017). A Research Agenda for Neoliberalism. Cheltenham: Edward Elgar Publishing Blyth, M. (2013). Austerity. The History of a Dangerous Idea, Oxford: Oxford University Press 
Boeri, T., van Ours, J. (2008). The Economics of Imperfect Labour Markets, New Jersey: Pinceton University Press

Bohle, D. (2009). „Race to the Bottom? Transnational Companies and Reinforced Competition in the Enlarged European Union“. U: Van Apeldoorn, B., Drahokoupil, J., Horn. L. (ur.) (2009). Contradictions and Limits of Neoliberal European Governance: From Lisbon to Lisbon. Palgrave Macmillan: Basingstoke, str. 163-186

Bourdieu, P., Wacquant, L. (2001). „New Liberal Speak: Notes on the New Planetary Vulgate.“ Radical Philosophy: 105:2-5

Braun, V., Clarke, V (2006). „Using thematic analysis in psychology“. Qualitative Research in Psychology, 3 (2), 77-101.

Cahill, D. (2014). The End of Laissez-Faire? On the Durability of Embedded Neoliberalism. Cheltenham: Edward Elgar Publishing

Ciepley, D. (2004). „Authority in the Firm (and the Attempt to Theorize it Away)“. Critical Review, 16: 81-115.

Crnkić, T. (2014). „Probni rad, obrazovanje i osposobljavanje za rad; Čl. 53 - 59“, U: Bejaković, P. (et. al.). (2014). Zakon o radu s komentarima i tumačenjima. Zagreb: Tim Press

Daniels. G, McIlroy, J. (ur.) (2009). Trade Unions in a Neoliberal World: British Trade Unions under New Labour. London: Routledge

Deakin, S. and Wilkinson, F. (1994). „Rights vs. efficiency? The economic case for transnational labour standards.“ Industrial Law Journal 23: 289-310.

Esping-Andersen, G. (2003). Social Foundations of Postindustrial Economies. Oxford: Oxford University Press

Esping-Andersen, G., Regini, M. (ur.) (2000). Why Deregulate Labour Markets?. New York: Oxford University Press

Esping-Andersen, G. (2000). „Who is Harmed by Labour Market Regulations? Quantitative Evidence“, U: Esping-Andersen, G., Regini, M. (ur.) (2000). Why Deregulate Labour Markets?. New York: Oxford University Press, str. 66-98

Fairclough, N. (1992). „Discourse and text: linguistic and intertextual analysis within discourse analysis“, Discourse and Society. Vol. 3(2), str. 193-217, London: Sage

Fairclough, N. (1995). Critical Discourse Analysis: the Critical Study of Language. London, New York: Longman

Fairclough, N. (1996). Language and Power. New York: Longman (Prvo izdanje: 1989)

Fairclough N., Wodak R. (1997) „Critical discourse analysis“. U: van Dijk, T. Discourse as Social Interaction. London: Sage, str. 258-284

Fairclough, N. (1999). „Global capitalism and critical awareness of language“. Language Awareness. Vol. 8, No. 2, str. 71-83 
Fairclough, N. (2002). „Language in New Capitalism.“, U: Discourse and Society. Vol. 13(2). str. 163-166

Fairclough, N. (2003). Analysing Discourse: Textual Analysis for Social Research, London: Routledge

Fairclough, N. (2004). „Critical Discourse Analysis in Researching Language in the New Capitalism: Overdetermination, Transdisciplinarity and Textual Analysis." u L. Young \& C Harrison (eds.). Systemic Functional Linguistics and Critical Discourse Analysis, Continuum 2004a, 103-122

Fairclough, N. (2006). Discourse and Social Change. Cambridge: Polity Press (Prvo izdanje 1992)

Flowerdew, J. L., Li, D. C. S. \& Tran, S. (2002). „Discriminatory news discourse: some Hong Kong data." Discourse and Society, 13(3), str. 319-345

Franičević, V., Puljiz, V. (ur.) (2009). Rad u Hrvatskoj: pred izazovima budućnosti, Pravni fakultet Sveučilišta u Zagrebu

Foucault, M. (1977). „Truth and Power“. U: Power and Knowledge, Alessandro Fontana i Pasquale Pasquino, New York: Pantheon, str. 109-133

Foucault, M. (2002). The Archaeology of Knowledge. London: Routledge

Foucault, M. (2008). The Birth of Biopolitics: Lectures at the College de France 1978-79. Palgrave Macmillan

Gee, J. P. (2007). Ideology in Discourses. London, New York: Routledge.

Granovetter, M. (1992). „Economic Action and Social Structure: the Problem of Embeddedness“. U: Granovetter M., Swedberg, R. (ur.). (1992). The Sociology of Economic Life. Boulder, San Francisco, Oxford: Westview Press, str. 53-81

Harvey, D. (2005). A Brief History of Neoliberalism.Oxford: Oxford University Press

Hayek, F. A. (1998). „The Market Order or Catallaxy.“ U: Hayek, F. A. (1998). Law, Legislation and Liberty. Vol. 2, London: Routledge, str. 107-132

Hayek, F. A. (2001). Put u ropstvo. Zagreb: Kruzak

Hayek, F. A. (2011). The Constitution of Liberty. Chicago: The University of Chicago Press

Hyman, R. (2005). „Trade unions and the politics of the European social model“, Economic and Industrial Democracy, 26 (1), Sage Publications, str. 9-40

Jackson. B. (2016). „Neoliberalism, labour and trade-unionism“, U: Springer, S., Birch K., MacLeavy. J. (ur.). (2016). The Handbook of Neoliberalism. New York: Routledge, str. 262 270

Jessop, B. (2003). The Future of the Capitalist State. Cambridge: Polity Press

Jessop, B. (2016). „The Heartlands of Neoliberalism and the Rise of the Austerity State.“, U: Springer, S., Birch K., MacLeavy. J. (ur.). (2016). The Handbook of Neoliberalism. New York: Routledge, str. 410-421 
Jørgensen, M. W., Phillips, L. J. (2002). Discourse Analysis as Theory and Method. London: Sage Publication

Kasunić Peris, M. (2014). „Radno vrijeme; Čl. 60 - 70“U: Bejaković, P. (et. al.). (2014). Zakon o radu s komentarima i tumačenjima. Zagreb: Tim Press, str. 158 - 173

Kendall, G. (2007). „What Is Critical Discourse Analysis?“. Forum Qualitative Sozialforschung / Forum: Qualitative Social Research, 8(2).

Kincheloe, J. L., McLaren, P. L. (2005). „Rethinking critical theory and qualitative research“. In N. K. Denzin\& Y. S. Lincoln (Eds.), Handbook of qualitative research, ThousandOaks, CA, US: Sage Publications, Inc., str. 303-342

Kress, G. (1990). „Critical Discourse Analysis“. Annual Review of Applied Linguistics (1990) 11, Cambridge University Press, str. 84-99

Kulušić, J. (2009). Isplati li se fleksibilnost. Zagreb: TIM Press

Larner, W. (2000). „Neo-Liberalism: Policy, Ideology, Governmentality“, Studies in Political Economy 63, Autumn

Locke, T. (2004). Critical Discourse Analysis. London: Continuum.

Macdonald, M. (2003). Exploring Media Discourse. London: Arnold.

MacLeavy, J. (2016). „Neoliberalism and Welfare.“ U: Springer, S., Birch K., MacLeavy. J. (ur.). (2016). The Handbook of Neoliberalism. New York: Routledge, str. 252-261

Mason, M. (2010). „Sample Size and Saturation in PhD Studies Using Qualitative Interviews.“ Forum for Qualitative Social Research, 11, (3)

Matković, T., Biondić, I. (2003). „Reforma Zakona o radu i promjena EPL indeksa.“ Financijska teorija i praksa, 27 (4), 515-528

McBride, S., McNutt, K, Williams, R. (2007). „Tracking Neo-Liberalism: Labour Market Policies in the OECD Area." u: Lee, S., McBride, S. (eds.). Neo-Liberalism, State Power and Global Governance, Springer, str. 79-93

McIlroy, J. (2009). „A brief history of British trade unions and neoliberalism: From the earliest days to the birth of New Labour“. U: Daniels. G, McIlroy, J. (ur.) (2009). Trade Unions in a Neoliberal World: British Trade Unions under New Labour. London: Routledge, str. 21-62.

Mills, S. (2004). Discourse. London: Routledge

Milković, D. (2014). „Prestanak ugovora o radu; Čl. 112 - 130“. U: U: Bejaković, P. (et. al.). (2014). Zakon o radu s komentarima i tumačenjima. Zagreb: Tim Press, str. 233 - 255

Mirowski P., Plehwe D. (eds). (2009). The Road from Mont Pèlerin. The Making of the Neoliberal Thought Collective. Harvard: Harvard University Press

Mrsić, M. (2014). „Predgovor“. U: Bejaković, P. (et. al.). (2014). Zakon o radu s komentarima i tumačenjima. Zagreb: Tim Press, str. 7-10 
Muffels, R. J. A., Luijkx, R. (2008). „Labour market mobility and employment security of male employees in Europe: 'trade-off' or 'flexicurity'.“ Work, Employment and Society. 22 (2), 221242

Muntigl, P., Weiss, G., Wodak, R. (2000). European Union Discourses on Un/employment: An Interdisciplinary Approach to Unemployment Policy-making and Organizational Change. Amsterdam, Philadephia: John Benjamins Publishing Company

Muntigl, P. (2000). The European Union: Policy-making through organizational discursive practices, u: Muntigl, P., Weiss, G., Wodak, R. (2000). European Union Discourses on Un/employment: An Interdisciplinary Approach to Unemployment Policy-making and Organizational Change. Amsterdam, Philadephia: John Benjamins Publishing Company, str. $1-25$

Palley, T. (2005). „From Keynesianism to Neoliberalism: Shifting paradigm in Economics.“ U: Saad Filho A., Johnston, D. (2005). Neoliberalism: A Critical Reader. London: Pluto Press, str. 20-29

Peck, J. (1996). Work-place: the Social Regulation of Labor markets. New York: The Guilford press, str. 1-20

Peck, J., Tickell, A. (2002). „Neoliberalizing space“, Antipode, str. 380 -404

Peters, M. (2016). „Education, Neoliberalism anad Human Capital: Homo oeconomicus as 'entreprenour of himself'،, U: Springer, S., Birch K., MacLeavy. J. (ur). (2016). The Handbook of Neoliberalism. New York: Routledge, str. 297 - 307.

Phelan, S. (2007a). „The Discursive Dynamics of Neo-liberal Consensus - Irish broadsheet editorials and the privatization of Eircom.“ Journal of language and politics, 6(1), 7-28

Phelan, S. (2007b). „The Discourses of Neoliberal Hegemony“. Critical Discourse Studies, Vol. 4, No. 1 , str. $29-48$

Phelan, S. (2014). Neoliberalism, Media and the Political. New York: Palgrave Macmillan

Puljiz, V. (2006). „Neoliberalizam i socijalna država.“ u: Vidović, D., Pauković, D. (ur.) Globalizacija i neoliberalizam. Refleksije na hrvatsko društvo, Zagreb: CPI, str. 121-130

Regini, M. (2000). „The Dilemmas of Labour Market Regulation“. u: Esping-Andersen, G., Regini, M. (eds.) Why Deregulate the Labour Market?, str. 11-29

Reisigl, M., Wodak, R. (2001). Discourse and Discrimination. Rhetorics of Racism and Antisemitism. New York: Routledge

Richardson, J. E. (2007). Analysing Newspapers. An Approach from Critical Discourse Analysis. Hampshire: Palgrave Macmillan

Saldaña, J. (2013). The Coding Manual for Qualitative Researches. Sage

Springer, Simon (2012). „Neoliberalism as discourse: between Foucauldian political economy and Marxian poststructuralism." Critical Discourse Studies, Vol. 9, No.1, 133-147

Springer, S., Birch K., MacLeavy. J. (ur). (2016). The Handbook of Neoliberalism. New York: Routledge. 
Stanford, J., Vosko, L. (eds.) (2004). Challenging the Market: The Struggle to Regulate Work and Income. McGill's-Queen University Press, str. 3-30

Steger, M. B., Roy, R. K. (2010). Neoliberalism: A Very Short Introduction. New York: Oxford University Press

Talbot, M. M. (2007). Media Discourse: Representation and Action. Edinburgh: Edinburgh University Press

Turner, R. (2008). Neo-Liberal Ideology: History, Concepts and Policies. Edinburgh: Edinburgh University Press

Van Apeldoorn, B., Drahokoupil, J., Horn. L. (ur.) (2009). Contradictions and Limits of Neoliberal European Governance: From Lisbon to Lisbon. Palgrave Macmillan: Basingstoke

Van Apeldoorn, B. (2009). „The Contradictions of 'Embedded Neoliberalism' and Europe's Multi-level Legitimacy Crisis: The European Project and its Limits“, U: Van Apeldoorn, B., Drahokoupil, J., Horn. L. (ur.) (2009). Contradictions and Limits of Neoliberal European Governance: From Lisbon to Lisbon. Palgrave Macmillan: Basingstoke, str. 21-43

Van Dijk, T. (1988). News as Discourse. Hillsdale, New Jersey, Hove, London: Lawrence Erlbaum Associates.

Van Dijk, T. (1993). „Principles of Critical Discourse Analysis“. Discourse and Society. London: Sage, Vol. 4(2): 249-283.

Van Dijk, T. (1995). „Aims of Critical Discourse Analysis.“ Japanese Discourse, vol. 1, 17-27

Van Dijk, T. (2001). „Critical Discourse Analysis“. U: Schiffrin, D., Tannen, D., Hamilton, H. E. (ur.) (2001). The Handbook of Discourse Analysis. Oxford: Blackwell, str. 352-371

Van Dijk, T. (2009). „Critical discourse studies: a sociocognitive approach“. U: Ruth Wodak \& Michael Meyer (Eds.), Methods of critical discourse analysis. London: Sage, str. 62-85

Van Leeuwen, T (2005). Introducing Social Semiotics. New York: Routledge, str. 93-116

Van Leeuwen, T. (2008). Discourse and Practice: New Tools for Critical Discourse Analysis. New York: Oxford University Press

Vinković, M. (2014). „Zaštita trudnica, roditelja i posvojitelja“. U: Bejaković, P. (et. al.). (2014). Zakon o radu s komentarima i tumačenjima. Zagreb: Tim Press

Wodak, R. (2000). „From Conflict to Consensus? The co-construction of a policy paper“. U: Muntig. P., Weiss, G., Wodak, R. European Union Discourses on Un/employment. An interdisciplinary approach to employment policy-making and organizational change. Amsterdam: John Benjamins, str. 73-114

Weiss, G. i Wodak, R. (2003). „Introduction: Theory, Interdisciplinarity and Critical Discourse Analysis“. U: Weiss G. i Wodak R. (ur.), Critical Discourse Analysis. Theory and Interdisciplinarity. Palgrave Macmillan, London, str. 1-32.

Wodak, R., Meyer, M. (ur.) (2009). Methods of Critical Discourse Analysis. London: Sage. 
Zeko, M. (2015). „Pozitivno pravna regulacija sezonskog zapošljavanja u Republici Hrvatskoj.“, Zbornik radova Međimurskog veleučilišta u Čakovcu, Vol. 6, No. 2, str. 159-167

Zeytinoglu, I. U. (ur.) (2005). Flexibility in Workplaces: Effects on Workers, Work Environment and the Unions. Geneva: IIRA/ILO. ISBN Web pdf: 92-2-116130-7; Web html:92-2-1161315

\section{Novine}

*** „HDZ neće glasati za novi Zakon o radu jer ide na uštrb radnog čovjeka“, Večernji list. (19. 2. 2013.), str. 2

*** „Radnika na probnom radu moći će se lakše otpustiti.“, Jutarnji list. (15. 6. 2013), str. 8

*** „Laburisti: S ovakvim Zakonom o radu radit ćemo za minimalac.“, Večernji list. (24. 8. 2013.), str. 18

*** „Vlada će smanjiti prava radnika!“‘, Jutarnji list, (27. 8. 2013.), str. 2

*** „Robu je bilo bolje nego danas radniku“, Večernji list, (18. 10. 2013.), str. 2

*** „Mrsić: 'Nismo se prepali sindikata'“, Večernji list, (5. 12. 2013.), str. 6

*** „Mudrinić: Sindikati ne razumiju teško stanje u Hrvatskoj“, Jutarnji list, (26. 1. 2014.), str. 7

*** „Vlada protiv generalnog štrajka: 'Novi ZOR ne krši prava pa štrajk nije regularan'“, Jutarnji list, (3. 2. 2014.), str. 2

*** „Opći štrajk zadnjeg dana veljače?“, Jutarnji list, (15. 2. 2014.), str. 7

*** „HDZ traži povlačenje Zakona o radu iz saborske procedure.“, Večernji list, (21. 2. 2014.), str. 17

*** „Ribić: Ako vlast ne povuče ZOR, ići ćemo na peticiju za raspisivanje izbora.“, Jutarnji list, (23. 2. 2014.), str. 4

*** „Vlada ne daje ultimatum, sjednimo ponovno za stol.“, Jutarnji list, (24. 2. 2014.), str. 5

*** „Lesar: Ako je ovo najbolja vlada koju je Hrvatska dosad imala, onda smo u ozbiljnim problemima“, Večernji list, (26. 2. 2014), str. 6

*** ,'Ovo je još jedan neuspjeli pokušaj Vlade'“, Večernji list, (27. 2. 2014.), str. 8

*** „Izglasan ZOR u prvom čitanju, Vlada i sindikati pozvani na dogovor.“, Večernji list, (1. 3. 2014.), str. 7

Barilar, Suzana. „Mijenjaju se otkazni rokovi, otpremnine, radno vrijeme...“, Jutarnji list. (14. 6. 2013.), str. 12

Barilar, Suzana. „Predrag Bejaković: Odlazak starijih u mirovinu neće zaposliti mlade.“, Jutarnji list, (12. 9. 2013.), str. 4 
Bešker, Inoslav. „Pravom na štrajk u roku od jedan dan država štiti svoj proračun“, Jutarnji list, (11. 8. 2013), str. 18-19

Biončina, Marko. „Prvi ugovor o radu na određeno bez roka trajanja“. Večernji list. (25. 5. 2013.), str. 13

Bolanča, S.,,Sindikati: 'Odgodite Zakon o radu i mi ćemo osigurati socijalni mir i odustati od generalnog štrajka'“, Jutarnji list, (11. 2. 2014.), str. 3

Bolanča, Sandra.,,Skup sindikata na Markovu trgu. Tisuću radnika protiv novog Zakona o radu“, Jutarnji list, (17. 2. 2014.), str. 9

Brnić, Marija. „Službenicima umjesto rješenja o namještenju ugovor o radu?“, Večernji list, (10. 6. 2014.), str. 20-21

Buljan, Velinka. „Gotovac: Veća prava radnika nisu realna, no treba inzistirati na zaštiti“, Večernji list, (14. 10. 2013.), str. 7

Butković, Davor. „Posao vođe u teškom vremenu. Vrijeme je da Zoran Milanović preuzme odgovornost za cijelu Vladinu politiku.“, Jutarnji list, (14. 12. 2013.), str. 21

Butković, Davor. „Treba razmisliti o tome da i guverner HNB-a uđe u Vladu.“, Jutarnji list, (2. 1. 2014.), str. 18

Butković, Davor. „Još jedan jalov politički kompromis.“, Jutarnji list, (4. 7. 2014.), str. 7

Ćurić, Dražen. „Je li moguća velika koalicija? Za velike rezove i reforme Milanoviću treba jak saveznik“, Večernji list, (26. 9. 2013.), str. 10-11

Drljača, Gojko. „Iznenađuje nova reformska odlučnost, znači li pravu mudrost.“, Večernji list. (17. 1. 2013.), str. 27

Drljača, Gojko. „Očekivanje podrške nezaposlenih ružan je cinizam sindikalaca.“, Večernji list. (16. 1. 2014.), str. 27

Drljača, Gojko. „Rastu šanse da u izbornoj godini zatražimo pomoć EU.“, Večernji list. (22. 2. 2014.), str. 2-3

Drljača, Gojko. „Bitka za ZOR je bitka za osobne karijere političara.“, Večernji list. (4. 3. 2014.), str. 9

Drljača, Gojko. „Boris Vujčić: Od početka krize HNB je vladama kupovao vrijeme za reforme.“, Večernji list. (19. 4. 2014.), str. 1, 4-6

Galović, Gordana. „Ugovori na određeno vrijeme neće se smjeti produljivati beskonačno”, Jutarnji list. (14. 2. 2013.), str. 7

Galović, Gordana. „U obnovu dva hotela ulažu 20 millijuna eura i uvode avio-taxi.“, Jutarnji list. (27. 4. 2013.), str. 20-21

Galović, Gordana. „Novi Zakon o radu: Tvrtke sad mogu lakše zaposliti radnike.“, Jutarnji list. (25. 5. 2013.), str. 4-5 
Galović, Gordana. „Prije krize bili smo nekonkurentni. Statistika ni danas ne signalizira rast.“, Jutarnji list, (1. 6. 2013)., str. 70-71

Galović, Gordana. „Mrsić: Podmetnite leđa, pomozite radnicima; HUP: Šokirate nas nejasnoćama“, Jutarnji list, (10. 10. 2013.), str. 13

Galović, Gordana. „Poslodavac radniku uplaćuje doprinos na poseban račun, a on ga koristi u slučaju otkaza“, Jutarnji list, (16. 10. 2013.), str. 10

Galović, Gordana. „Alka Obadić: 'Hrvatski su radnici previše zaštićeni i to im šteti...'“, Jutarnji list, (7. 11. 2013.), str. 22-23

Galović, Gordana. Turčin, Kristina. „Razorno novo izvješće Europske unije: prvi put više od pola Hrvata ne radi!“, Jutarnji list, (13. 12. 2013.), str. 1, 8-9

Galović, Gordana. „Izmjene radnih zakona nose nova radna mjesta”, Jutarnji list. (22. 1. 2014.), str. 7

Galović, Gordana. „U štrajk idu čak i radnici HEP-a i gubitaškog HŽ-a”, Jutarnji list. (1. 2. 2014.), str. 4

Galović, Gordana. „Intervju Željko Potočnjak: 'Nećemo izaći iz krize ako Vlada ne smanji plaće službenicima i ne počne otpuštati'”, Jutarnji list. (17. 2. 2014.), str. 7

Galović, Gordana. „Hrvatska je u najtežoj krizi, a od svih je najmanje rezala plaće birokratima”, Jutarnji list. (17. 2. 2014.), str. 1, 6-7

Galović, Gordana. „Pregovori bez rezultata. Sindikati: nećemo dopustiti tvrtkama da lakše otpuštaju", Jutarnji list. (2. 4. 2014.), str. 11

Galović, Gordana. „Pao dogovor o Zakonu o radu: za 90 tisuća zaposlenih otkazi bez objašnjenja”, Jutarnji list. (4. 4. 2014.), str. 1-3

Gašparić, Krunoslav. „Zašto Vlada ne štiti sve radnike?“, Blog Kapitalac, Jutarnji list, (2. 4. 2014.), str. 10

Gatarić, Ljubica. „Veće naknade za nezaposlene, ali manje otpremnine.“, Večernji list. (16. 1. 2013.), str. 1-3

Gatarić, Ljubica. „U SAD-u godišnji odmor nije zakonska obveza.“, Večernji list. (4. 5. 2013.), str. 5

Gatarić, Ljubica. „Rehn kroji proračun: Hrvatska 22. listopada gubi fiskalni suverenitet!“, Večernji list, (7. 9. 2013.), str. 1-3

Gatarić, Ljubica. „Branko Roglić: 'U životu se mora umrijeti i platiti porez. Ništa drugo'““, Večernji list, (13. 9. 2013.), str. 16-17

Gatarić, Ljubica. „Gotovac: Od čestih promjena koristi imaju samo pravnici“, Večernji list, (14. 9. 2013.), str. 5

Gatarić, Ljubica. „Linić stao na stranu sindikata, Mrsić to odbio komentirati“, Večernji list, (3. 1. 2014.), str. 2

Gatarić, Ljubica. „Sindikati pozvali Mrsića da odustane od još dvije odredbe“, Večernji list, (16. 1. 2014.), str. 4-5 
Gatarić, Ljubica. „Poduzetnici poručili Mirandu Mrsiću: Dajte nam optimizma“, Večernji list, (22. 5. 2014.), str. 18-19

Gotovac, Viktor. „Jeste li čuli da ćemo raditi do kasne sijede starosti? Nećemo.“, Jutarnji list, (4. 12. 2013.), str. 18

Jelić, Nikola. „Branko Roglić: 'Plaćam čak 50 parafiskalnih nameta državi'“, Jutarnji list, (1. 10. 2013.), str. 15

Jelić, Nikola. „Mladen Fogec: '55\% hrvatskog izvoza nose strane tvrtke. Njihova snaga je ogromna.'“, Jutarnji list, (16. 11. 2013.), str. 32-33

Jelić, Nikola. „Pobuna najvećih stranih ulagača: 'Svi su protiv nas, a zaslužni smo za pola hrvatskog izvoza'“, Jutarnji list, (24. 11. 2013.), str. 24-27

Jurasić, Dijana. „Smrt socijalne države: Bez stalnog radnog mjesta društvo se urušava.“, Večernji list, (29. 10. 2013.), str. 18-19

Klepo, Marina. „Švaljek: 'Treba hrabriti one koji ulaze u rizik na tržištu!'.“, Jutarnji list,(31. 1. 2013.), str. 13

Kovačević Barišić, Romana; Špoljar, Marko. „Lakši otkazi i radni tjedan od najviše - 56 sati.“, Večernji list, (24. 1. 2014.), str. 2-3

Kovačević Barišić, Romana. „Štrajka će biti ako Vlada ne popusti. Procjene kažu da 90 posto članova želi štrajk. Ako ne povuku ZOR, slijedi radikalizacija“, Večernji list, (26. 1. 2014.), str. 1, 16-17

Kovačević, Romana. „Opći štrajk solidarnosti od 12 do 14 sati na Markovom trgu.“, Večernji list, (25. 2. 2014.), str. 1,4

Kovačević, Barišić Romana. „'Umjesto socijaldemokrata, nazovite se neoliberali!“, Večernji list, (27. 2. 2014.), str. 8-9

Kovačević, Barišić Romana. „Ribić iz nove sindikalne zgrade poručuje: 'Ovako se stvara nova vrijednost!'“‘, Večernji list, (13. 3. 2014.), str. 11

Kovačević, Barišić Romana. „Radit će se više za manje novca, agencijski radnici bit će traženi, ali jeftiniji konkurenti.“, Večernji list, (26. 6. 2014.), str. 1, 4-5

Lepan, S. ,'Zakon o radu ne da mi da legalno zaradim za kredit!'.“, Večernji list, (28. 3. 2013.), str. 7

Lukić, Slavica. „HDZ: ZOR narušava odnos rada i kapitala.“, Jutarnji list, (21. 2. 2014.), str. 9

Majetić, Davor. „Koji referendum će smanjiti nezaposlenost?“, HUP komentar, Večernji list, (5. 12. 2013.), str. 18

Majetić, Davor. „Odgovornost prema društvu iliodgovornost prema stranci??“, HUP komentar, Večernji list, (27. 2. 2014.), str. 20

Maretić Žonja, Petra. „Rent-a-radnik i tri godine - Produljuje se rok za privremeno zapošljavanje“, Večernji list, (28. 2. 2014.), str. 6

Milovan, Adriano. „Viktor Gotovac, stručnjak za radno pravo: 'Zakon o radu trebalo je promijeniti odjednom'.“, Jutarnji list. (12. 6. 2013.), str. 10 
Milovan, Adriano. „Viktor Gotovac, docent na Pravnom fakultetu: 'Hrvatski radnik budućnosti stalno mora usvajati nove tehnologije i biti spreman preseliti se zbog posla'.“, Jutarnji list. (13. 6. 2013.), str. 10

Milovan, Adriano. „Pet sindikata zaprijetilo vladi: U siječnju referendum, a onda krećemo u štrajk.“, Jutarnji list. (13. 12. 2013.), str. 7

Milovan, Adriano. „Poslodavcu prvo žuti karton, a onda kazna.“, Jutarnji list. (22. 5. 2014.), str. 5

Milovan, Adriano. „Socijalni partneri se i dalje spore. Poslodavci tražili 56 sati rada, sindikati manje od 50.“, Jutarnji list. (26. 6. 2014.), str. 7

Milovan, Adriano. „Glad i bijeda: Hrvatska u vrhu crne statistike, više nezaposlenih samo u Grčkoj i Španjolskoj.“, Jutarnji list. (1. 7. 2014.), str. 1-3

Milovan, Adriano. „Zakon o radu kasni pet godina i kao takav neće pomoći izlasku iz krize.“, Jutarnji list,(4. 7. 2014.), str. 6

Nestić, Danijel. „Posao ne traži svaki treći radno sposoban.“, Jutarnji list, (25. 2. 2014.), str. 23

Novaković, Nataša. „Zakon o radu kao poticaj zapošljavanju“, HUP komentar, Večernji list, (17. 10. 2013.), str. 20

Patković, Nikola. ,'Država mi brani da radim dva posla i za to me kažnjava?!' Osječanin o borbi sa skandaloznim Zakonom o radu.“, Jutarnji list. (26. 2. 2013.), str. 1, 14-15

Pavić, Ante. „Države i poslodavci paničnim se rezovima natječu u utrci prema dnu“., Jutarnji list. (4. 1. 2013.), str. 16

Penić, Goran. „Intervju Mirando Mrsić: 'U ovoj državi nitko ne želi prave reforme. Svi ih se boje."“, Jutarnji list, (14. 7. 2014.), str. 1, 8-9

Pleše, Mladen. „Poučak slučaja Linić. Građani podržavaju one koji provode promjene.“, Jutarnji list, (24. 8. 2013.), str. 27-28

Potočnjak, Željko. „Rad i poduzetništvo kao temelji fleksigurnosti radnih odnosa.“, HUP komentar, Večernji list. (14. 3. 2013.), str. 21

Puljić-Šego, Iva. „I za državne službenike vrijedit će Zakon o radu.“, Večernji list, (15. 2. 2014.), str. 3

Radusinović, Dragana. „Vilim Ribić: 'Nije točno da država nema novca. Uvijek ga imaju, uostalom mogu ga uzeti od bogatih'.“, Jutarnji list. (27. 4. 2013.), str. 23, 26-27

Radusinović, Dragana. „Šokantna istina o turizmu.”, Jutarnji list. (5. 5. 2013.), str. 14

Radusinović, Dragana. „Ukinuti sva ograničenja koja stopiraju zapošljavanje.”, Jutarnji list, (24. 8. 2013.), str. 12

Radusinović, Dragana. „Je li nam Zakonom o radu oduzeto pravo da radimo?”, Jutarnji list, (25. 8. 2013.), str. 19

Radusinović, Dragana. „Vlada povukla na doradu Zakon o radu: 'Ne bojimo se sindikata, ZOR usuglašavamo s Europskom Unijom'”, Jutarnji list, (4. 12. 2013.), str. 4-5 
Radusinović, Dragana. „Liberalniji Zakon o radu nećemo imati zbog loših Mrsićevih procjena.", Jutarnji list, (8. 12. 2013.), str. 19

Radusinović, Dragana. „Intervju: Dragutin Lesar: 'Istina je, previše je ljudi zaposleno u javnom sektoru'“, Jutarnji list, (27. 2. 2014.), str. 1, 8-9

Rak Šajn, Jolanda. „Lakše zapošljavanje i otkazi poslodavcima najvažniji u ZOR-u.“, Večernji list, (5. 2. 2014.), str. 18

Rak Šajn, Jolanda. „Davor Majetić: 'Za reforme nam trebaju čelnici kao što je Angela Merkel'.“, Večernji list, (6. 6. 2014.), str. 28-29

Romić, Tea. „Zoran Milanović: Nećemo ukinuti drugi stup, nego ćemo ga korigirati.”, Večernji list, (29. 1. 2014.), str. 4

Romić, Tea. „Bez štrajka barem pola godine, ako se toliko odgodi ZOR.”, Večernji list, (11. 2. 2014.), str. 3

Škegro, Borislav. „Ako ulagačima ne štimaju brojke uzalud priče o investicijama.”, Ekonomija ekonomistima, Večernji list, (19. 10. 2013.), str. 6

Škegro, Borislav. „Barem poslušajmo Tony Barbera. On je, nažalost - u pravu.”, Ekonomija ekonomistima, Večernji list, (28. 6. 2014.), str. 10

Špoljar, Marko. „HNS: Treba nam 3 milijarde eura pomoći fonda.”, Večernji list, (24. 10. 2013.), str. 2-3

Špoljar, Marko. „Premijer nakon sastanka s koalicijskim partnerima: 'Ne možemo živjeti na dug, moramo smanjiti neke rashode" Večernji list, (25. 1. 2014.), str. 3

Šunjerga, Marina. „Vlada gleda gdje uštedjeti 2 mlrd., stručnjaci kažu da mora barem 3.“, Večernji list, (5. 2. 2013.). str. 1-3

Šunjerga, Marina. „Končar i Siemens zajedno u proizvodnju vlakova za HŽ.“, Večernji list, (13. 3. 2013.), str. 8

Šunjerga, Marina. „Poslodavci: Nudimo pomoć. Vlada se ne snalazi.“, Večernji list, (24. 5. 2013.), str. 1-3

Šunjerga, Marina. „Tonemo. Sve je teže iščupati se iz gliba. Vlada se treba ojačati. Poduzetnici traže konsenzus o tome kakvo društvo želimo.“, Večernji list, (1. 6. 2013.), str. 1, 4-6

Šunjerga, Marina. „Mircea Draja: 'Ulažemo u ljude i želimo zadržati proizvodnju Coca-cole u Hrvatskoj'“, Večernji list. (23. 9. 2013.), str. 22

Šunjerga, Marina. „Tauno Olju: 'Za novac iz fondova EU trebate puno više projekata'“, Večernji list, (17. 10. 2013.), str. 20-21

Šunjerga, Marina. „Ante Babić, tajnik Udruženja stranih ulagača: 'Da barem godinu dana ne rastu porezi i da je lakše do dozvola'“, Večernji list, (25. 11. 2013.), str. 22-23

Šunjerga, Marina. „80 posto poslodavaca: Oporavka nema, davat ćemo otkaze i 2014.“, Večernji list, (11. 12. 2013.), str. 6 
Šunjerga, Marina. „Ministar Vrdoljak: 'Što će biti na sastanku s MOL-om? Bit će svega'.“, Večernji list, (24. 4. 2014.), str. 3

Turčin Kristina, Galović, Goga. „Doznajte što se sve mijenja u novom Zakonu o radu“, Jutarnji list, (27. 2. 2014.), str. 1, 6-7

Vlašić, Boris. „Intervju Mirsada Kudrović: 'Hrvatska ima najatraktivnije poticaje u regiji.'“, Jutarnji list, (17. 6. 2014.), str. 19-21

Vresnik, Viktor. „Kraj politike škrtosti? Ni slučajno. Čelični stisak neće popustiti. Ovo je samo šansa davljeniku za jedan udah.“, Jutarnji list, (1. 6. 2013.), str. 30-31

Vresnik, Viktor. „Sve je moguće mijenjati, Zakon o radu nije iznimka.“, Jutarnji list, (2. 6. 2013.), str. 16

Vresnik, Viktor. „I država i sindikati tjeraju nas na život ispod površine.“, Jutarnji list, (4. 6. 2014.), str. 4

Vujić, Antun. „Manifest za novu socijaldemokraciju: Što učiniti dok kapitalizam jede socijalnu državu.", Jutarnji list, (9. 3. 2013.), str. 21, 34, 55-56

Vuković, R. „Mrsić: Vlada je na sebe preuzela težinu odluke da donese novi zakon o radu.“, Jutarnji list, (29. 11. 2013.), str. 4

Vuković, Rozita. „Bez investicija, još jedna generacija Hrvata ići će vani trbuhom za kruhom.“, Jutarnji list, (5. 3. 2014.), str. 14

Vuković, Vuk. „Kratki priručnik za privlačenje investitora: što znaju Makedonci i Gruzijci, a ne znaju Hrvati.“, Jutarnji list, (28. 12. 2013.), str. 28-30

Wiegand, Johannes. „Procjena o precijenjenoj kuni ne govori o tečaju nego o konkurentnosti.“, Jutarnji list, (1. 6. 2014.), str. 19 


\section{DODACI}

\section{Dodatak 1. Kodna struktura}

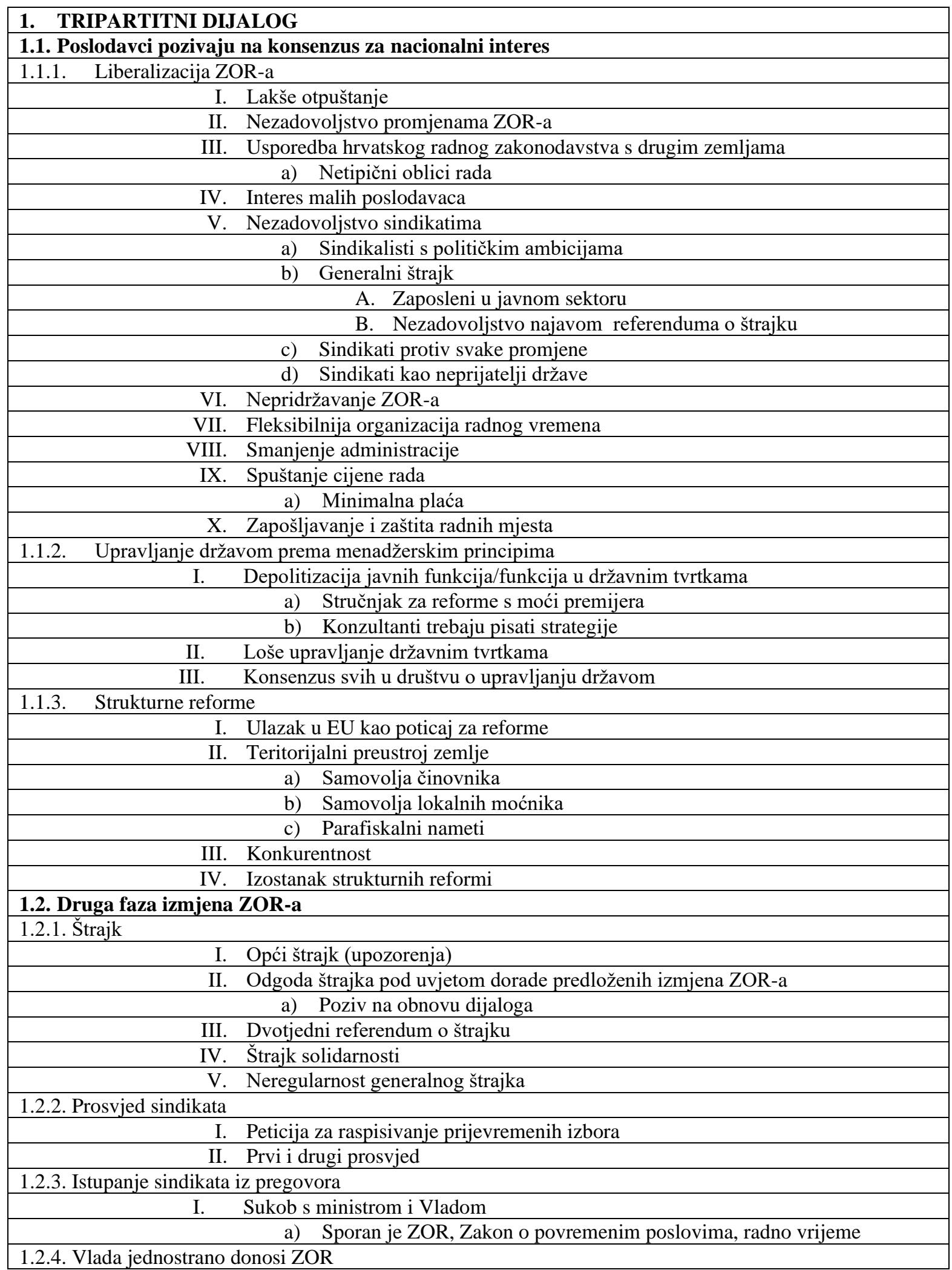




\begin{tabular}{|c|}
\hline I. Vlada poziva na konsenzus \\
\hline II. Vlada poziva na obnovu dijaloga \\
\hline III. Nezadovoljstvo Vlade reakcijom sindikata \\
\hline 1.2.5. Nezadovoljstvo sindikata dijalogom \\
\hline I. Novi ZOR znači smanjenje cijene rada, pogoduje krupnom kapitalu \\
\hline II. Jednostrano postupanje Vlade \\
\hline III. Mimoilaženje sindikata preko radničkih vijeća \\
\hline 1.2.6. Odbijanje dijela kritika sindikata \\
\hline I. Slabija regulacija rada preko agencija, produljenje rada na 3 godine \\
\hline II. Produljenje radnog tjedna \\
\hline 1.2.7. Vlada dorađuje ZOR \\
\hline I. Usuglašavanje s EU \\
\hline II. Podizanje konkurentnosti \\
\hline 1.2.8. ZOR izglasan u prvom čitanju \\
\hline I. Nezadovoljstvo partnera novim ZOR-om \\
\hline
\end{tabular}

\section{IZMJENE ZAKONA O RADU}

\subsection{Numerička fleksibilnost}

2.1.1. Otpremnine

I. Problem javnog sektora/kolektivni ugovori

II. Proširenje prava na otpremninu

III. Prijedlog Vlade - fond otpremnina

a) Problematičnost fonda otpremnina

b) Preporuka Svjetske banke

IV. Smanjenje iznosa otpremnina

2.1.2. Lakše otpuštanje radnika

I. Potpuna liberalizacija procedura otpuštanja za male poduzetnike

II. Zamjena redovnih radnika agencijskim

III. Otkazni rok

IV. Tehnološki višak, probni rad, kolektivni otkaz

2.1.3. $\quad$ Agencijski rad

I. Promicanje agencijskog rada

a) Radnici imaju ista prava

b) Radnici ne plaćaju naknade

II. Kritika agencijskog rada

a) Zamjena za standardni radni odnos

b) Nepovoljni uvjeti rada u agencijama za privremeno zapošljavanje

c) Nesigurnost zaposlenja

d) Rad za nižu plaću

III. Rad na više poslova

IV. Reguliranje rada agencija

2.1.4. Ugovori na određeno vrijeme

I. Prvi ugovor bez ograničenja

II. „Insideri“" $\mathrm{i}$, ,outsideri“

III. Ograničenje produljivanja ugovora

IV. Kritika produljivanja ugovora na određeno

\subsection{Fleksibilnost radnog vremena}

2.2.1. Smanjenje ograničenja prekovremenog rada

I. Kontrola inspektorata

II. Pisani nalog za prekovremeni rad

2.2.2. Prepreke u sezonskom radu

I. Minimalno trajanje odmora između smjena

II. Trošak prijevoza i smještaja sezonaca

III. Raspodjela radnog vremena

2.2.3. Postojeći ZOR onemogućuje rad dva posla

2.3. Usklađivanje zakonodavstva s EU direktivama

2.3.1. Brže restrukturiranje 


\begin{tabular}{|c|c|}
\hline \multicolumn{2}{|c|}{ 2.4. Kritika postojećeg ZOR-a } \\
\hline 2.4.1. & Postojeći ZOR onemogućuje gospodarski razvoj \\
\hline 2.4 .2 . & Postojeći ZOR odvraća domaće i strane investitore, čimbenik nekonkurentnosti \\
\hline & I. Novi napredniji zakon za privlačenje investitora \\
\hline & II. Rigidan postojeći zakon \\
\hline & III. Nejasnoće u regulativi \\
\hline & IV. Upozorenja MMF-a i Svjetske banke \\
\hline 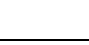 & a) World competitiveness index \\
\hline
\end{tabular}

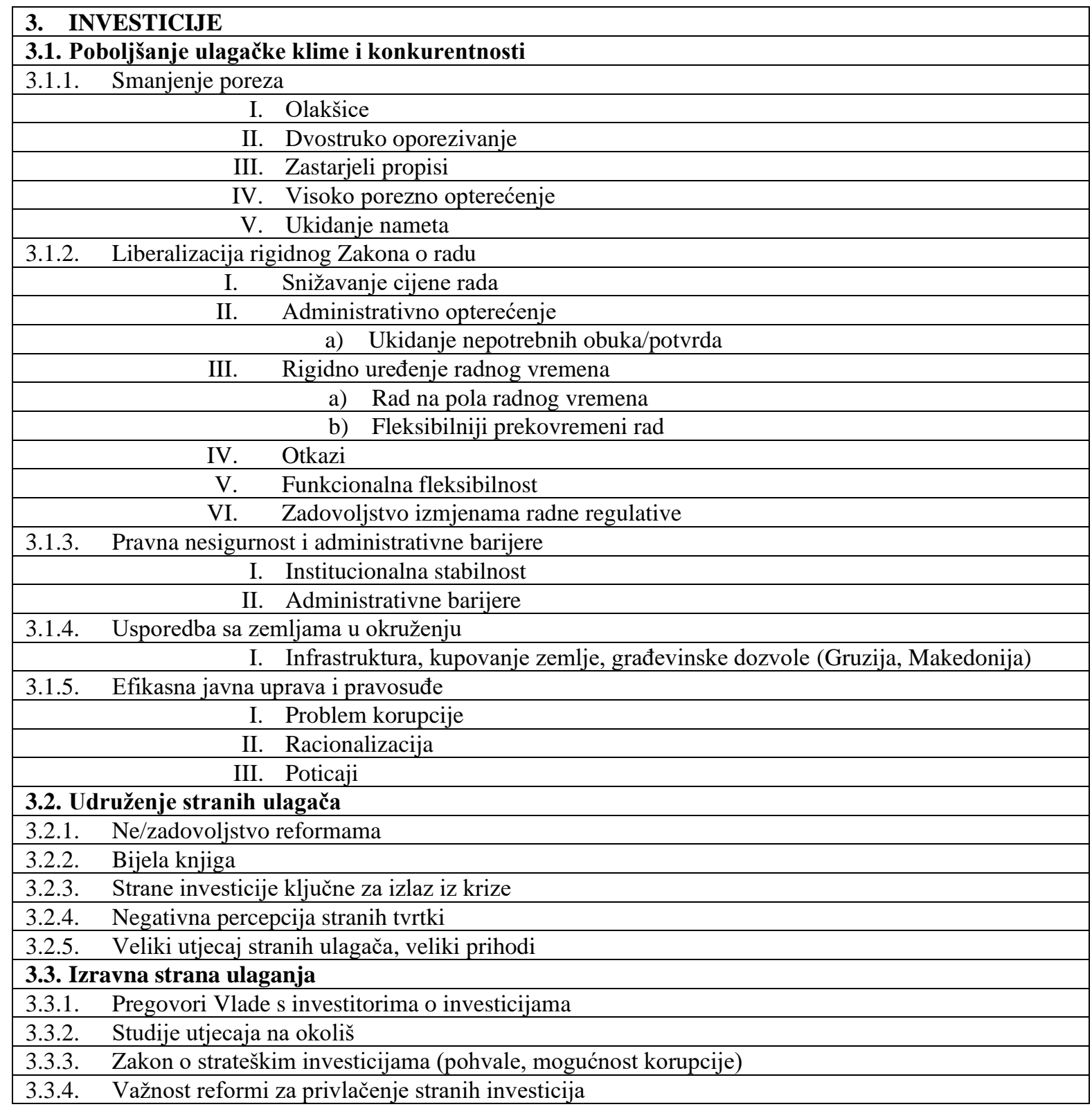

\begin{tabular}{|c|c|}
\hline 4. & STERITET \\
\hline 4.1. 1 & cedura prekomjernog deficita \\
\hline 4.1 .1 & Traženje pomoći EU i MMF-a \\
\hline 4.1 .2 & Rezanje rashoda \\
\hline & I. Smanjenje gradova i općina \\
\hline & II. Rezanje državnih investicija \\
\hline & a) Rezove treba usmjeriti na javni sektor \\
\hline & b) Državnu potrošnju treba usmjeriti na privatni sektor \\
\hline
\end{tabular}




\begin{tabular}{|c|c|}
\hline III. Velika & oalicija \\
\hline \multicolumn{2}{|c|}{ IV. Plaće u državnom i javnom sektoru (Zakon o plaćama u javnom sektoru) } \\
\hline \multicolumn{2}{|c|}{ a) Linearno rezanje plaća } \\
\hline \multicolumn{2}{|r|}{ b) Smanjenje dodataka na plaću po kolektivnim ugovorima } \\
\hline \multicolumn{2}{|c|}{ c) Smanjenje koeficijenata } \\
\hline \multicolumn{2}{|l|}{ 4.2. Strukturne reforme } \\
\hline Kreditni rejting & \\
\hline \multicolumn{2}{|c|}{ I. Poticaj za izmjenu ZOR-a } \\
\hline \multicolumn{2}{|c|}{ Nužnost fleksibilizacije tržišta rada } \\
\hline \multicolumn{2}{|c|}{ Stvaranje učinkovite uprave i javnog sektora } \\
\hline \multicolumn{2}{|l|}{ U zemljama EU } \\
\hline \multicolumn{2}{|c|}{ Obveze Hrvatske prema EU će je prinuditi na strukturne reforme } \\
\hline \multicolumn{2}{|c|}{ Veća zaštićenost radnika u javnom sektoru/državnom sektoru } \\
\hline \\
\hline \multicolumn{2}{|c|}{$\begin{array}{l}\text { 4.2.9. Zakon o radu umjesto Zakona o državnim službenicima } \\
\text { I. } \quad \text { Ukidanje povlaštenog statusa službenika }\end{array}$} \\
\hline \multicolumn{2}{|r|}{ a) Izbacivanje "balasta" iz javne uprave } \\
\hline & Bolje plaće i prava u javnom sektoru \\
\hline
\end{tabular}

\begin{tabular}{|ll|}
\hline 5. & NEZAPOSLENOST I NISKA ZAPOSLENOST \\
\hline 5.1. & Usporedba Hrvatske i zemalja EU \\
\hline 5.1 .1$. & Neprovođenje strukturnih reformi \\
\hline $5.1 .2 . \quad$ Problem prijevremenog umirovljenja \\
\hline 5.1 .3$. & Nepovoljna struktura stanovništva koje ne radi \\
\hline 5.1 .4$. & Ulaganje u istraživanje i razvoj \\
\hline 5.2. & Nefleksibilnost tržišta rada \\
\hline $5.2 .1 . \quad$ Neusklađenost obrazovanja s potrebama tržišta \\
\hline 5.2.2. $\quad$ Isključenost mladih iz tržišta rada \\
\hline \multicolumn{2}{c}{ I. Iseljavanje } \\
\hline 5.2.3. $\quad$ Mjere aktivnog zapošljavanja \\
\hline 5.3. Premalo cjeloživotnog učenja \\
\hline $5.3 .1 . \quad$ Nekonkurentnost radne snage \\
\hline 5.3.2. & Potreba ulaganja pojedinaca u obrazovanje \\
\hline
\end{tabular}

\begin{tabular}{|ll|}
\hline 6. & KRITIKA POLITIKE ŠTEDNJE \\
\hline 6.1. Kritika smanjivanja plaća i državne potrošnje \\
\hline 6.1 .1$. & Alternativne metode povećanja kapitala i investicija \\
\hline \multicolumn{1}{|c|}{ I. $\quad$ Aktivne politike dohotka za koje se zalaže UNCTAD } \\
\hline 6.1 .2$. & Smanjenje osobne potrošnje smanjuje BDP \\
\hline 6.2. & Nestanak socijalne države \\
\hline 6.2 .1$. & Nestalnost radnog mjesta \\
\hline 6.2 .2$. & Negativni demografski trendovi \\
\hline 6.2 .3$. & Besplatno školstvo i zdravstvo \\
\hline 6.2 .4$. & Zapošljavanje mladih \\
\hline 6.3. Fleksibilizacija kao eufemizam za otpuštanje \\
\hline 6.3 .1$. & Kritika Vladine politike prema radnicima \\
\hline 6.3 .2$. & Hrvatska smanjuje troškove rada \\
\hline 6.3 .3$. & Tretiranje radnika kao robova \\
\hline 6.3 .4$. & Potrebne dodatne zaštite radnika \\
\hline 6.4. Kriza socijaldemokracije \\
\hline 6.4 .1$. & Porazi socijaldemokracije na izborima \\
\hline 6.4 .2$. & Prihvaćanje politike štednje \\
\hline 6.4 .3$. & Srednja klasa se okreće desnom centru \\
\hline 6.4 .4$. & Ekonomska kriza \\
\hline
\end{tabular}




\section{ŽIVOTOPIS}

Helena Trbušić rođena je 1983. godine u Karlovcu. Završila je Osnovnu školu Dubovac i Gimnaziju Karlovac općeg usmjerenja. 2008. godine završila je dvopredmetni studij engleskog jezika i književnosti i sociologije na Filozofskom fakultetu u Zagrebu. 2009. godine zapošljava se na Katedri za sociologiju pri Fakultetu strojarstva i brodogradnje Sveučilišta u Zagrebu. 2016. godine zapošljava se na Twinning projektu „Unaprjeđenje kvalitete provedbe nacionalnih programa ranog otkrivanja raka“ pri Hrvatskom zavodu za javno zdravstvo. 2019. godine zapošljava se u Ministarstvu znanosti i obrazovanja. 2021. godine zapošljava se u Ministarstvu prostornoga uređenja, graditeljstva i državne imovine.

\section{Radovi:}

Trbušić, Helena (2014) „Engineering in the Community: Critical Consciousness and Engineering Education.“ Interdisciplinary Description of Complex Systems. 12, 2; 108-118 Trbušić, Helena (2013) „Holistic education: the social reality of engineering.“ The Journal of Education Culture and Society. 2; 227-238

Trbušić, Helena (2013) „Transformations in Engineering Education: A Perspective into Changes towards a Holistic Approach“ Education Culture and Society - Nowadays Challenges / Kanonowicz, Michal (ur.). Wroclaw.

Trbušić, Helena (2012) „Sustainability Communication and the Transformative Role of Engineering Education“, Management of Technology Step to Sustainable Production MOTSP 2012 Conference Zagreb: Croatian Association for PLM, 474-481.

Trbušić, Helena, Dubreta, Nikša (2011) „Engineering Education and Social Responsibility: A Qualitative Study of Non-technical Electiveness“ Management of Technology - Step to Sustainable Production, Zagreb : Fakultet strojarstva i brodogradnje, 527-534

Dubreta, Nikša; Janković, Vesna; Trbušić, Helena (2010). "Modelling a Pattern for Responsibility: Science and Theory of Sustainable Development" Strojarstvo. 52, 1; 17-22

Trbušić, Helena (2010) „Business Ethics and Managing Reputation“ Management of Technology - Step to Sustainable Production MOTSP 2010 Conference Proceedings, Zagreb: Fakultet strojarstva i brodogradnje, 588-595

Dubreta, Nikša; Trbušić, Helena (2009) „Engineering Work Perspectives and Sociocultural Fragments in Technical Education" 12th International Scientific Conference on Production Engineering : CIM 2009

Trbušić, Helena (2009) „Tisak i nacionalizam“ Socijalna ekologija. 18, 1; 58-79 